SAND82-1069

Distribution

Unlimited Release

Printed March 1983

Category UC -70

\title{
Deformation of Evaporites Near the Waste Isolation Pilot Plant (WIPP) Site
}

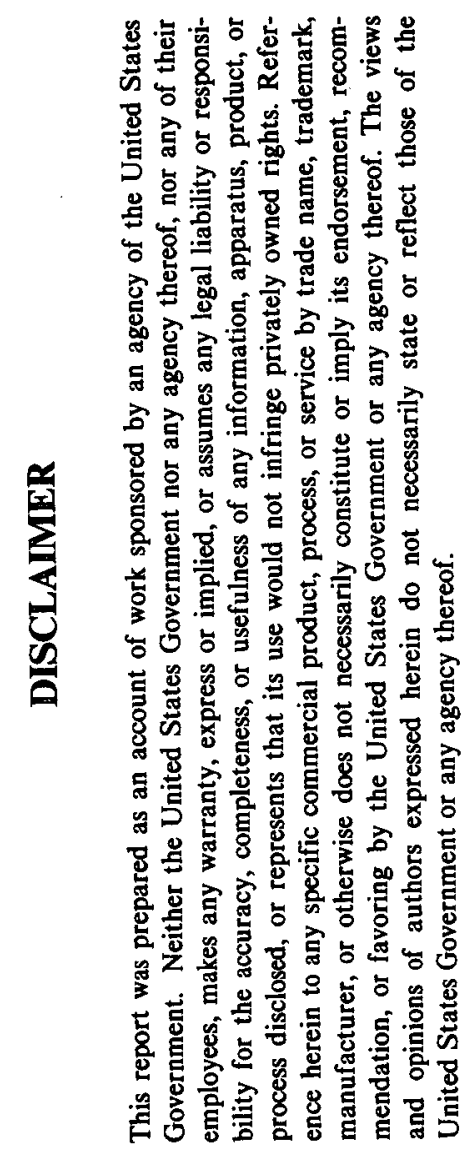

\author{
David J. Borns \\ Earth Sciences Division 9731 \\ Lawrence J. Barrows \\ Ground Motion and Seismic Division 7111 \\ Sandia National Laboratories \\ Albuquerque, NM 87185 \\ Dennis W. Powers \\ Department of Geological Science \\ University of Texas at El Paso \\ El Paso, TX 79968 \\ Richard P. Snyder \\ US Geological Survey \\ Denver Federal Center \\ Denver, CO 80225
}

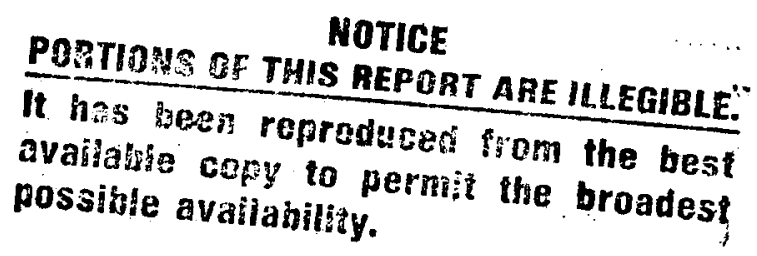

\section{Abstract}

The Delaware Basin is a broad asymmetric sedimentary trough in southeastern New Mexico and west Texas. Basin subsidence occurred from the Pennsylvanian into the Triassic. The basin also underwent tilting since the early Cenozoic.

Layered evaporite units of Ochoan age in the basin are $1000 \mathrm{~m}$ thick. These evaporites are divided into three stratigraphic units (listed in order of increasing age): the Rustler Formation, the Salado Formation, the Castile Formation. These units, especially the Castile, are deformed along portions of the margin of the Delaware Basin and in some areas internal to the basin. In the northern Delaware Basin adjacent to the WIPP site, the term "Disturbed Zone" (DZ) has been applied to an area in which deformation structures are found in boreholes and from which chaotic seismic reflection data were obtained. The origin and timing of this deformation is considered important for the determination of

This document is 


\section{DISCLAIMER}

This report was prepared as an account of work sponsored by an agency of the United States Government. Neither the United States Government nor any agency Thereof, nor any of their employees, makes any warranty, express or implied, or assumes any legal liability or responsibility for the accuracy, completeness, or usefulness of any information, apparatus, product, or process disclosed, or represents that its use would not infringe privately owned rights. Reference herein to any specific commercial product, process, or service by trade name, trademark, manufacturer, or otherwise does not necessarily constitute or imply its endorsement, recommendation, or favoring by the United States Government or any agency thereof. The views and opinions of authors expressed herein do not necessarily state or reflect those of the United States Government or any agency thereof. 


\section{DISCLAIMER}

Portions of this document may be illegible in electronic image products. Images are produced from the best available original document. 


\begin{abstract}
(cont)
failure scenarios for the WIPP site. However, the deformation does not present a major hazard to the construction and operational stages of the facility.

Geophysical studies (borehole logging, seismic reflection, and detailed gravity) have covered the DZ areas. Logs show vertical relief in the order of tens to hundreds of meters. Seismic profiles suggest a blocky structure with abrupt offsets and changes in dip between units. This chaotic structure occurs within the Castile Formation, but with little or no deformation exhibited by the overlying and underlying strata. Changes in seismic character, such as wiggle shapes, imply that unit thicknesses and/or acoustic properties vary. On the periphery of the $\mathrm{DZ}$, seismic profiles indicate salt flowage flexures. Outside the DZ, the seismic time structures appear to be generated by lateral velocity variations. The gravity field is dominated by anomalies originating in lateral density variations within relatively flat-lying strata. Low-amplitude, long-wavelength effects of $\mathrm{DZ}$ structures cannot be resolved.
\end{abstract}

Through detailed core description, both meso- and microscopic, fold-styles in the DZ units are separable into distinct stages and sequences of generation. An older sedimentary stage of folding is distinguished from later tectonic folding by microfabric development and opposite senses of asymmetry. The tectonic folding and deformation displays a progressive development of fabrics ending in latestage fracturing of competent anhydrite units. Petrofabrics reveal synkinematic growth of rotated anhydrite porphyroblasts and stress shadow growth. Microboudinage is also common. Of the possible deformation mechanism for anhydrite and halite, pressure solution appears the most applicable to the DZ. Therefore, an intergranular fluid plays an important role in facilitating deformation under the pressure, temperature, and stress histories of the region.

The following hypotheses of origin of deformation have been considered:

\author{
Gravity Foundering \\ Gravity Sliding \\ Gypsum Dehydration \\ Dissolution \\ Depositional Variations (e.g., thickness)
}

Of these, gravity foundering and sliding are considered the most probable causes of deformation. However, no hypothesis adequately answers why the deformation has a limited areal distribution. A possible explanation would be areal variations in rock strength caused by variations of intergranular water content. Age and timing of deformation are also crucial. Standard stratigraphic arguments based on superposition may not apply to such a highly incompetent material as halite. Gravity foundering could have happened at any time since deposition including the present; gravity sliding would probably have occurred since basin tilting began in the Cenozoic.

Deformation could be ongoing. However, the strain rates are such $\left(\approx 10^{-16} \mathrm{~s}^{-1}\right)$ that deformation would progress slowly relative to the facility's time frame of $2.5 \times 10^{5} \mathrm{yr}$. Deformation of Salado units would be minimal $(<10 \mathrm{~m})$ or nonexistent, but within this time frame, upper anhydrite units of the Castile could fracture and provide the volume for a brine reservoir. Such volumes would be small $(<1 \%)$ and would require $\approx 10^{4}$ to $10^{6} \mathrm{yr}$ to develop. At these strain rates, fractures that connect the fractured anhydrites of the Castile with the middle Salado could not develop. Deformation should not directly jeopardize the facility over thə next $2.5 \times 10^{5} \mathrm{yr}$. 


\section{Contents}

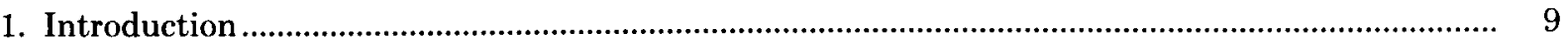

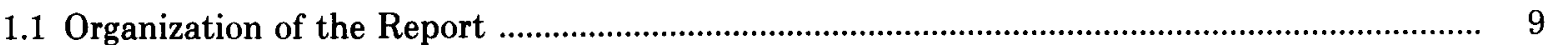

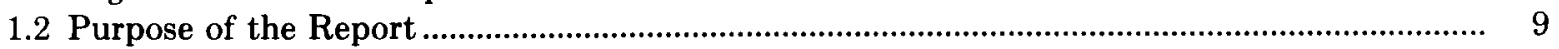

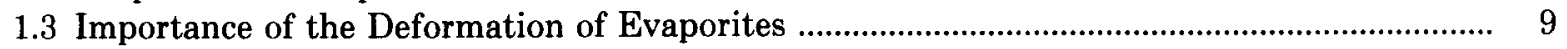

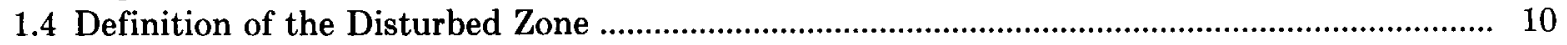

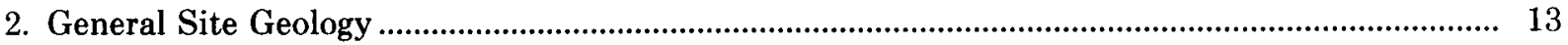

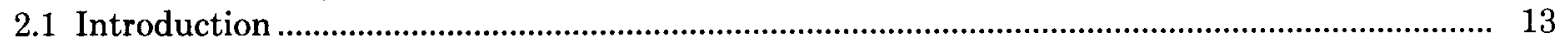

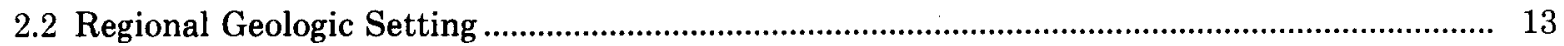

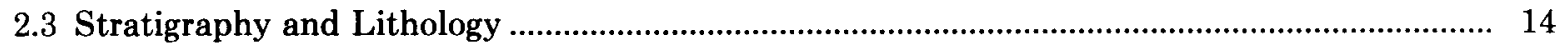

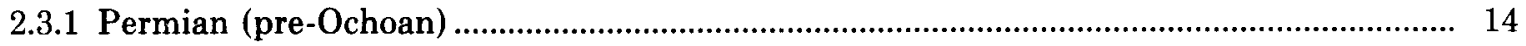

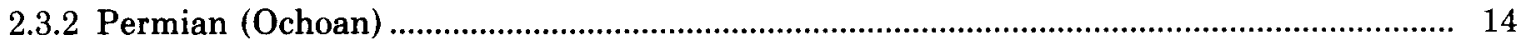

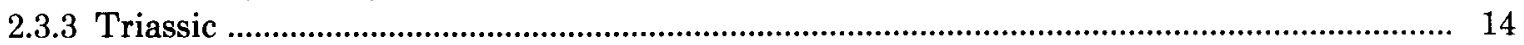

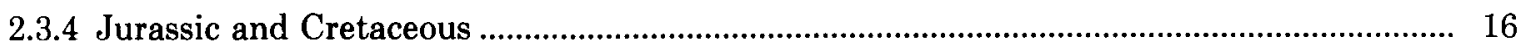

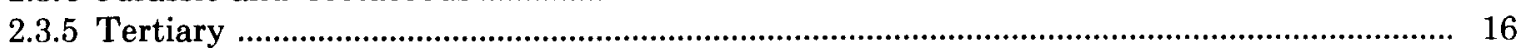

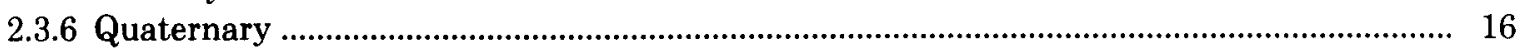

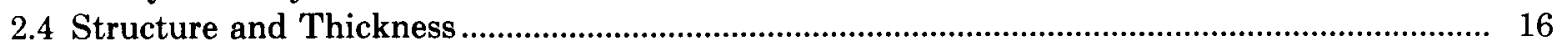

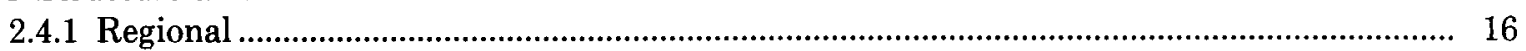

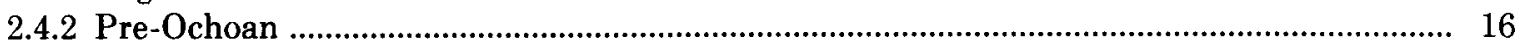

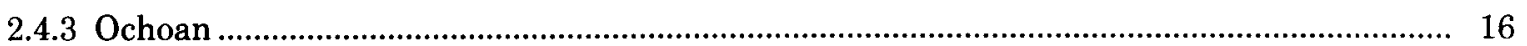

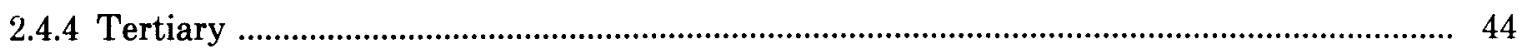

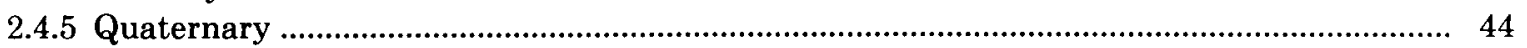

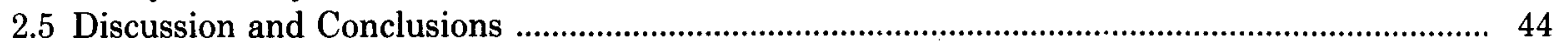

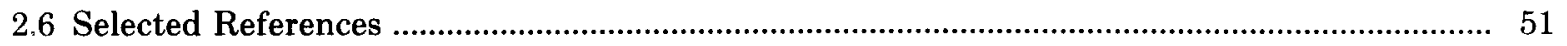

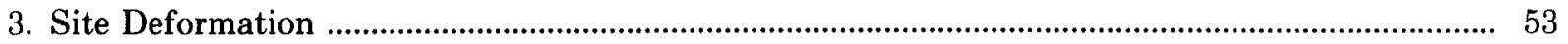

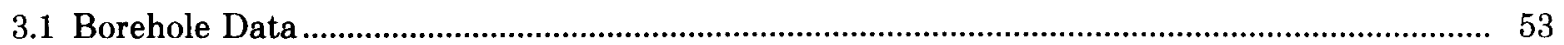

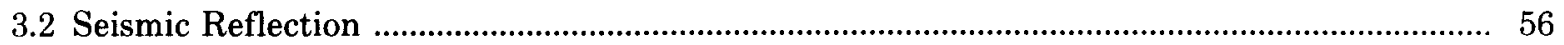

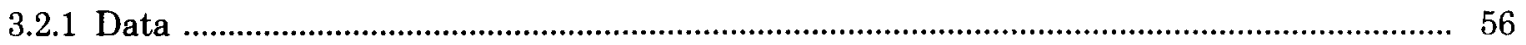

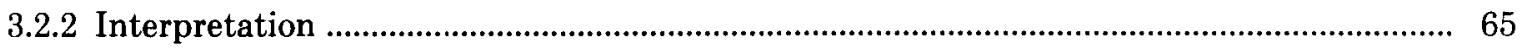

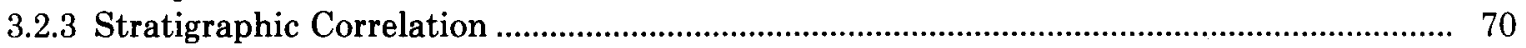

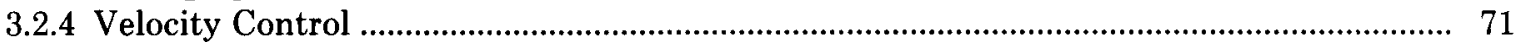

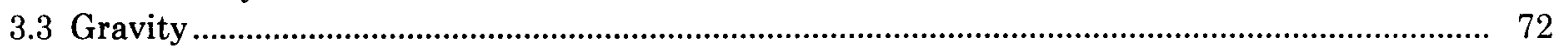

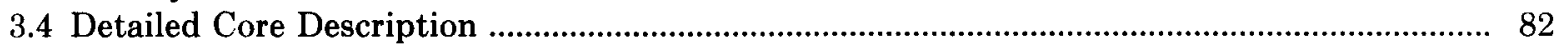

3.4.1 Multiple Fold and Deformation Textures ...................................................... 82

3.4.2 Petrographic Description: Deformation Mechanism ................................................. 83

4. Hypotheses of Origin ........................................................................................................... 87

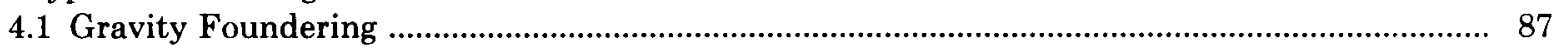

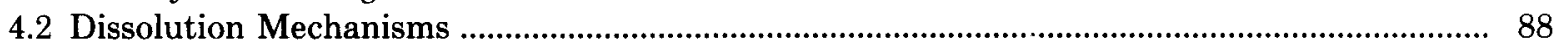

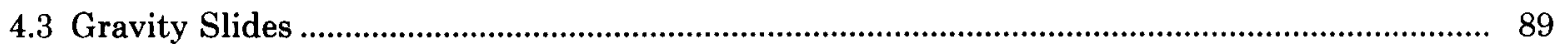

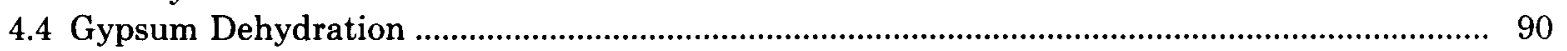

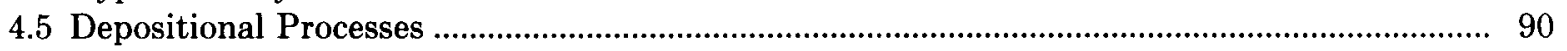

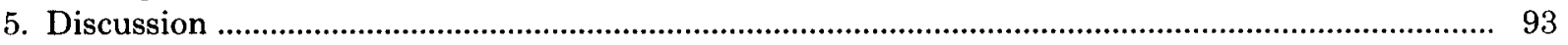

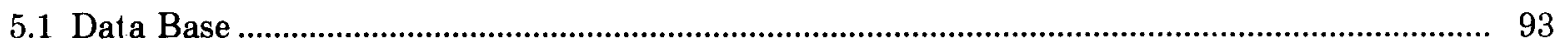

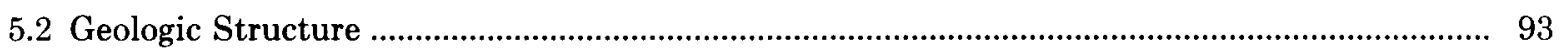

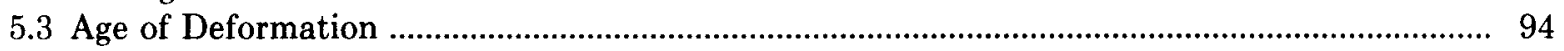

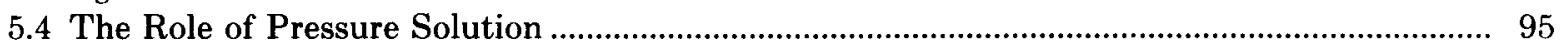

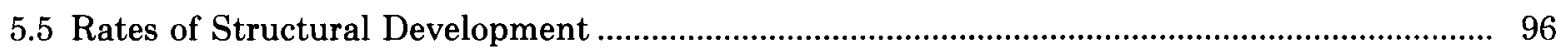




\section{Contents (cont)}

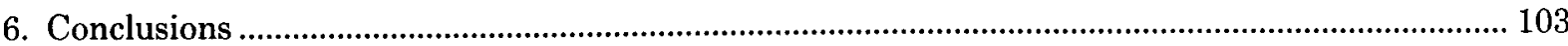

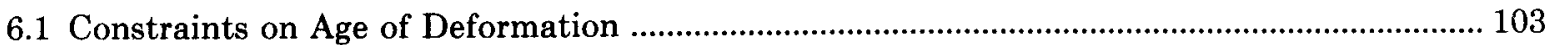

6.2 Syndepositional to Closely Postdepositional Deformation ......................................................... 103

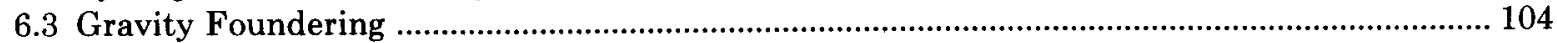

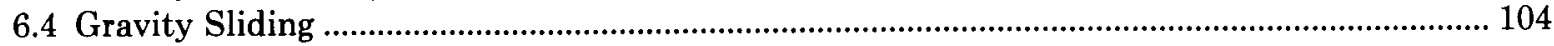

6.5 Effects of Various Mechanisms on Site Suitability and Stability .......................................... 104

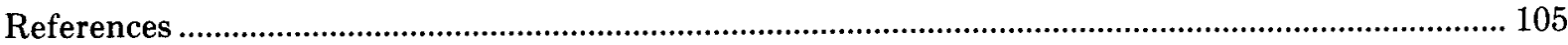

APPENDIX-Halokinetic Development of the Disturbed Zone

(by Larry Barrows, Sandia National Laboratories) ....................................................... 107

\section{Figures}

1-1 Areal Extent of the Disturbed Zone, Northern Delaware Basin ......................................... 10

1-2 Present Configuration of Surface Control Zones at the WIPP Site ................................... 11

2-1 Regional Setting, Northern Delaware Basin, Southeastern New Mexico ............................. 13

2-2 Generalized North-South Cross Section, Southeastern New Mexico .................................... 15

2-3 Structure Contour Map, Top of Bell Canyon Formation, Northern Part of Delaware Basin ................................................................................................................................... 17

2-4 Index Map Showing Lines and Drill Holes Used in Cross Sections Shown on Figures 2-5 and 2-6 .............................................................................................................. 20

2-5 North-South Cross Section, WIPP Site ........................................................................... 21

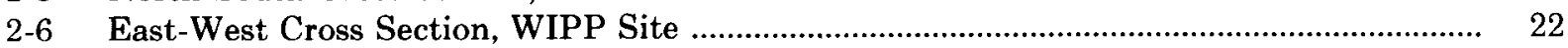

2-7 Structure Contour Map, Top of Anhydrite Unit AI, Castile Formation ............................... 23

2-8 Structure Contour Map, Top of Halite Unit HI, Castile Formation ..................................... 25

2-9 Isopach Map, Halite Unit HI, Castile Formation .................................................................. 26

2-10 Structure Contour Map, Top of Anhydrite Unit AII, Castile Formation ............................. 27

2-11 Structure Contour Map, Top of Halite Unit HII, Castile Formation ................................... 28

2-12 Isopach Map, Halite Unit HII, Castile Formation .................................................................... 29

2-13 Structure Contour Map, Top of Anhydrite Unit AIII, Castile Formation .......................... 30

2-14 Isopach Map, Anhydrite Unit AIII, Castile Formation …...................................................... 31

2-15 Structure Contour Map, Base of Cowden Anhydrite Member, Salado Formation ............. 32

2-16 Isopach Map, Base of Cowden Anhydrite Member to Top of Castile Formation ............... 33

2-17 Structure Contour Map, Top of Lower Unnamed Unit, Salado Formation ........................ 34

2-18 Isopach Map, Lower Unit, Salado Formation ....................................................................

2-19 Structure Contour Map, Top of McNutt Potash Zone, Salado Formation ........................ 37

2-20 Isopach Map, McNutt Potash Zone, Salado Formation ......................................................... 38

2-21 Structure Contour Map, Top of Salado Formation ................................................................ 39

$2-22$ Isopach Map, Upper Unit, Salado Formation .................................................................... 40

2-23 Location Map of 20 Drill Holes Used in Study of Salado Formation Marker Bed Intervals ... 41

2-24 Structure Contour Map, Top of Rustler Formation …............................................................ 42

$2-25$ Isopach Map, Rustler Formation ............................................................................................... 43

2-26 Structure Contour Map, Top of Dewey Lake Red Beds ...................................................... 45

2-27 Isopach Map, Dewey Lake Red Beds ......................................................................................... 46

2-28 Structure Contour Map, Top of Santa Rosa Sandstone ...................................................... 47

2-29 Isopach Map, Santa Rosa Sandstone ..................................................................................... 48

$2-30 \quad$ Isopach Map, Gatuña Formation .......................................................................................... 49 


\section{Figures (cont)}

3-1 Boreholes in the DZ That Penetrate the Castile Formation ...................................................... 53

3-2 Salado and Castile Formation Log Correlations in the DZ .................................................. 53

3-3 Salado and Castile Formation Log Correlations in the DZ ................................................. 54

3-4 Acoustilog Correlation of the Salado Formation in AEC 8 and WIPP 11 ......................... 55

3-5 Vibroseis Line Locations ............................................................................................. 57

3-6 Seismic Time Structure - Top of Castile Formation .............................................................. 58

3-7 Seismic Time Structure - Mid-Castile Formation .................................................................. 59

3-8 Seismic Time Structure - Top of Cherry Canyon Formation ............................................... 60

3-9 Seismic Time Structure - Top of Bone Spring Formation …………...................................... 61

3-10 Seismic Isochron - Top Castile to Mid-Castile …................................................................ 62

3-11 Seismic Isochron - Mid-Castile to Cherry Canyon ……........................................................... 63

3-12 Seismic Isochron - Cherry Canyon to Bone Spring ............................................................... 64

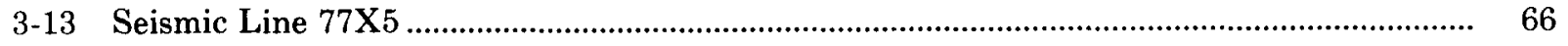

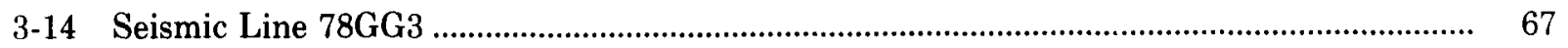

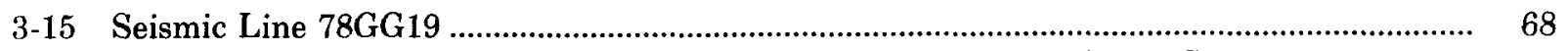

3-16 Comparison of Interval Velocities Measured During Uphole Velocity Surveys -

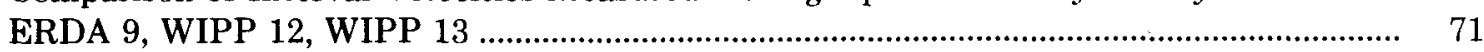

3-17 Compensated Densilog, Castile Formation, Borehole AEC 8 ............................................... 72

3-18 WIPP Gravity Survey, Detailed Areas, and Reconnaissance Profiles ................................. $\quad 74$

3-19 WIPP Gravity Survey, Simple Bouguer Gravity Map ……..................................................

3-20 WIPP Gravity Survey, Simple Bouguer Gravity Map in Vicinity of Borehole

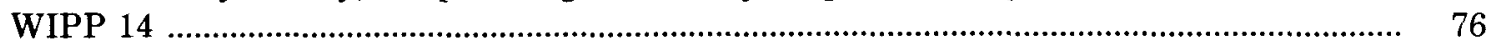

3-21 Profile Across the Negative Gravity Anomaly at Borehole WIPP 14 ................................. 77

3-22 That Portion of Seismic Line 77X2 That Intersects the Negative Gravity Anomaly ......... 78

3-23 Gravity Survey Line G ......................................................................................................... 80

3-24 Comparison of Interval Velocities Measured During Uphole Velocity Surveys WIPP 13, WIPP 34

3-25 Modeled Gravity Anomaly - Survey Line G ................................................................. 80

3-26 Deformation Styles in Laminated Carbonate Anhydrite Units of the Castile (WIPP 13, $3727 \mathrm{ft}$ )

3-27 Deformation Styles in Laminated Carbonate Anhydrite Units of the Castile (WIPP 13, $3727 \mathrm{ft}$ )

3-28 Deformation Styles in Laminated Carbonate Anhydrite Units of the Castile (WIPP 13, $3729 \mathrm{ft}$ )

3-29 Deformation Styles in Laminated Carbonate Anhydrite Units of the Castile

3-30 Synoptic Diagram of Log Stress vs Temperature Illustrates the Relative Strength at $10 \%$ Strain of Halite, Anhydrite, and Limestone Expected Under Geological Strain Rates ..

3-31 Rotated Anhydrite Neoblast; Synkinematic Growth Suggested by Helicitic Calcite-Opaque Mineral Inclusion

3-32 Pressure Shadow Growth of Anhydrite Neoblast; Microboudinage of Calcite Laminae ....

5-1 Geometry of Boundary Development of a Structure Such as the WIPP 12 Anticline ........ 


\section{Tables}

2-1 Geologic Markers in Exploratory Test Holes .............................................................................. 18

3-1 WIPP Site Seismic Surveys .................................................................................................... 56

3-2 Stratigraphic Identification of Uppermost Seismic Horizon ................................................. 70

3-3 Tentative Stratigraphic Identification of Lower Three Seismic Horizons ............................. 70

3-4 Measured Velocities and Calculated WIPP 11 Depth-Time Tie ........................................... 79

5-1 Strain Rates as Related to the Deformation Mechanism ..................................................... 97

5-2 The Effects on Comparative Strain Rates of Thermal and Stress Differences

Between WIPP Site and Gulf Coast Salt Domes ................................................................... 98

5-3 Comparative Strain Rate Calculations for Pressure Solution and Dislocation Climb @

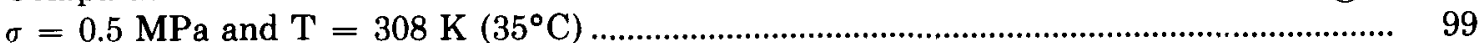

5-4 Time Required for Developing WIPP 12-Type Anticline at 1\% Volumetric Strain .......... 100

5-5 Horizontal Rate Calculations for Growth of an Anticline Edge ........................................... 101 


\section{Deformation of Evaporites Near the Waste Isolation Pilot Plant (WIPP) Site}

\section{Introduction}

\subsection{Organization of the Report}

This report is about a structural complex in the Castile and lowermost Salado Formations in the northern part of the WIPP site. The report is organized to accomplish several purposes. The Introduction provides a common ground for a definition of the Disturbed Zone (DZ) and points out some of its historical development. General Site Geology provides the borehole data and the interpretation of the US Geological Survey (USGS). Site Deformation reviews the site structures that are based on borehole, geophysical, and petrographic data. Hypotheses of Origin discusses in detail the proposed mechanisms to account for the DZ. (The gravity-foundering hypothesis is described in greater detail in the Appendix.) The Discussion probes some of the strengths and weaknesses in data and hypotheses. In the Conclusions, we present the preferred hypotheses in the judgment of the Sandia authors and discuss these hypotheses in terms of their relevance to site suitability.

\subsection{Purpose of the Report}

This report summarizes work to date on the $\mathrm{DZ}$ and related evaporite structures in the Delaware Ba$\sin$ of southeast New Mexico. The deformation associated with the $\mathrm{DZ}$ has been characterized by borehole, geophysical, and petrographic studies. The bulk of this work has been completed.

Various hypothetical mechanisms have been proposed to account for the observed deformation associated with the DZ:
- Gravity foundering of denser anhydrite members of the Castile through the less dense halite members

- Dissolution

- Gravity slide associated with basin tilting

- Gypsum dehydration

- Depositional variations in thickness

Investigations have included petrographic and geochemical characterization of cores, interpretation of gravity and level-line surveys, the relationship of structures to brine encounters in the Castile Formation, and model studies of deformation mechanisms. Some of this material is contained here; all will be covered in reports when the investigations are complete.

\subsection{Importance of the Deformation of Evaporites}

Existing geologic structures at the WIPP site do not present an obstacle to facility development. However, the development of reliable failure scenarios for the next $250000 \mathrm{yr}$ requires information on the characteristics of the deformation, its age, mode of origin, and relation to fluids. 


\subsection{Definition of the Disturbed Zone}

The evaporite beds are deformed around portions of the margin of the Delaware Basin and in some areas in the middle of the Basin. Deformation features in the northern part of the WIPP site have been lumped together under the term "Disturbed Zone" (DZ). The DZ is now delineated on the combined basis of structure exhibited in boreholes and by the chaotic seismic reflection data in the northern part of the site (see Figure 1-1).

- Structures on which the $\mathrm{DZ}$ is defined are thickened or thinned halite units of the Castile and anti- or synforms in anhydrite units of the Castile. Mesoscopic structures that are associated with the DZ are tight-to-open folding and boudinage of carbonate-anhydrite laminae. As suggested above, the $\mathrm{DZ}$ is based predominantly on Castile structures, whereas in the overlying Salado, deformation is nonexistent or weak; e.g., ERDA 6.
- The chaotic seismic reflection data, which is the other basis for delineating the $\mathrm{DZ}$, is characterized by discontinuous reflectors and a blocky return pattern (see Sec 3.2).

The term "Disturbed Zone" has been used historically in different ways during the discussion of the WIPP. The historical usage is reviewed to help readers understand prior discussions.

The DZ was recognized on the basis of seismic reflection data; we began with a review of proprietary industry data. Hundreds of line-miles of seismic reflection data were made available in 1976 to G. J. Long and Associates (1976) for review of shallow $(<4000-\mathrm{ft}$ ) reflectors in the northern Delaware Basin. Several seismic anomalies were identified in this review; one of the larger seismic anomalies was located 3 mi north of ERDA 9. At the time of the review, the extent and geologic character of the $\mathrm{DZ}$ were not recognized.

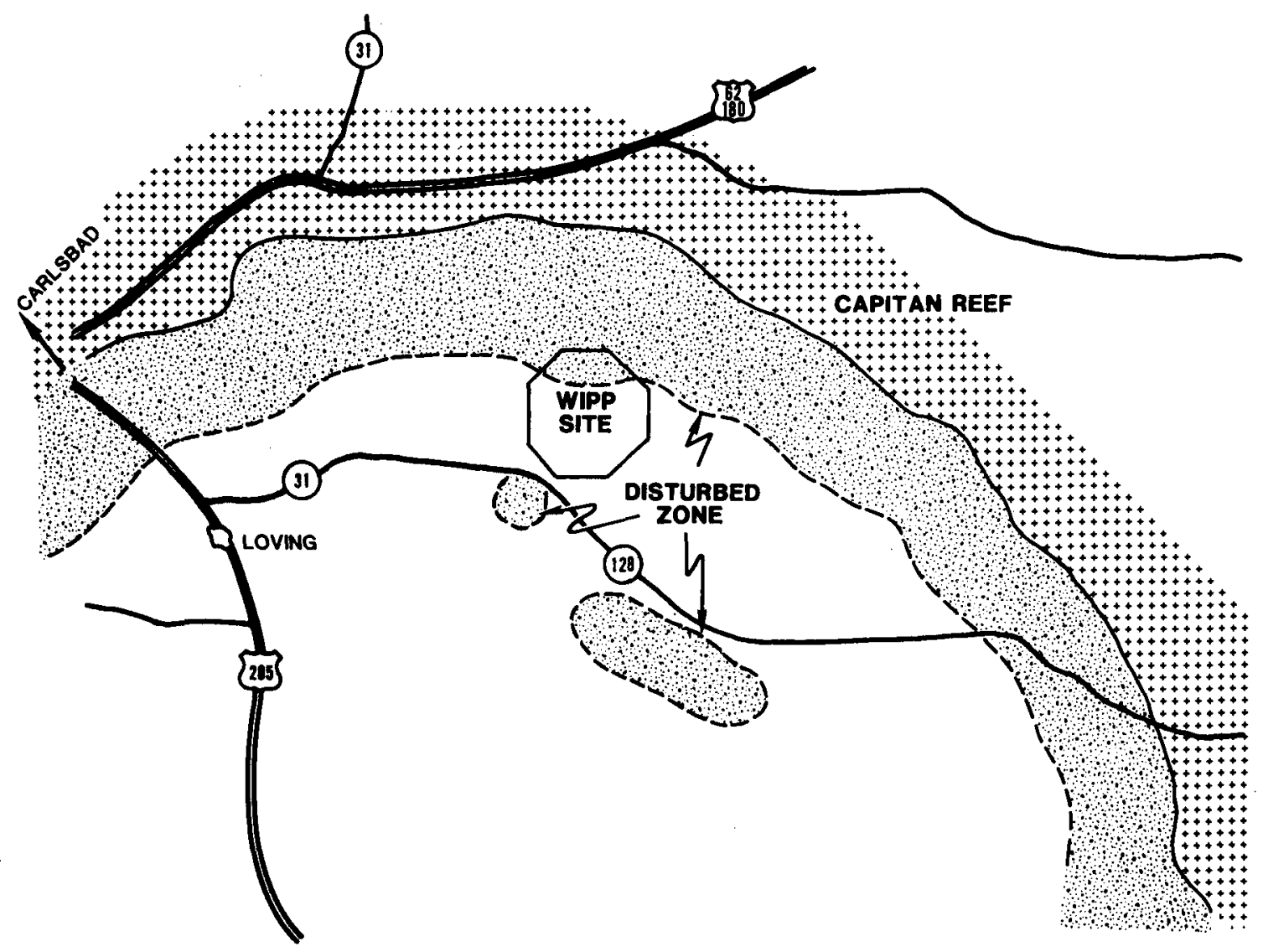

Figure 1-1. Areal Extent of the Disturbed Zone, Northern Delaware Basin 
During the latter half of 1977 , Sandia National Laboratories in Albuquerque (SNLA), assisted by G. J. Long and Associates, made a seismic reflection survey to obtain better shallow reflections and to cover the possible seismic anomalies identified earlier through data review. The survey, designated the 1977 X Geophysical Program, covered about 48 line-miles, including some offsite work. Full details of parameters and line locations for all SNLA seismic reflection data are contained in Hern et al (1979).

Preliminary interpretation of the $1977 \mathrm{X}$ seismic reflection data revealed an area in the northern part of the WIPP study area where shallow reflectors were not easily interpreted. A rough outline of an area called the "highly disturbed zone" was inferred on the basis of limited data then available. The highly disturbed zone was reported in Powers et al (1978, Figure 4.4-6). The limited amount of seismic reflection data and lack of good reflectors prevented significant interpretation of the internal structure of the DZ. The anomaly 3 mi north of ERDA 9 was included in the $\mathrm{DZ}$, and was investigated by drilling borehole WIPP 11 (SNLA and USGS, 1982).

In 1978 an additional small seismic reflection survey ("Y" series) was conducted by G. J. Long and Associates for SNLA (Hern et al, 1979). A more extensive survey was made by Bechtel for underground design and site evaluation (Bell and Murphy and Assoc., Inc., 1979; Dobrin, 1979). These data better define the boundary of the $\mathrm{DZ}$ and provide some indications of its internal structure.

By $1979 \mathrm{Sec}$ 16, 17 of R31E, T22S were being interpreted as either an area of anomalous seismic data or an area of complex geologic structure. At that time borehole WIPP 13 bottomed at $1025 \mathrm{ft}$ in the upper member of the Salado Formation. During 1980 the hole was deepened to the lowermost anhydrite of the Castile Formation to establish the origin of the seismic signals. The hole verified that the $\mathrm{DZ}$ was an area of complex geologic structures in the Castile and lowermost Salado Formations. Subsequent DZ investigations have included two high-resolution seismic experiments, the high-precision gravity survey, petrographic core analysis, development of tectonic models, and deepening of WIPP 12.

The seismic reflection data from 1978 are summarized in the WIPP Safety Analysis Report (SAR) (Department of Energy, 1980). The "zone of anomalous seismic reflection data" (Figures 2.7-23, 2.7-24, $2.7-30$ of the SAR) is used to indicate portions of the seismic records generally regarded as uninterpretable by these investigators. This zone is equivalent in definition to the early highly deformed zone in that uninterpretable seismic records are the bases. More seismic data resulted in a somewhat different boundary to this zone.

The SAR also shows a "line indicating steepening of dip of Castile strata to the north" (Figures 2.7-23, 2.7-24, 2.7-30) based on Bell and Murphy and Associates, Inc. (1979). This line approximately coincides with the southern boundary of the $\mathrm{DZ}$ as defined in this report; the Castile structure as exhibited in the northern part of Zone II now is included in the DZ by us (Figure 1-1). Thus, the area where the Castile/lower Salado departs from generally parallel beds with slight dip is the DZ. For the present, we assume a common origin for these structures. Several evaporite structures in the Delaware Basin (Anderson and Powers, 1978) may have similar origins.

NOTE: The configuration of WIPP surface control zones has changed as a result of the cost-reduction program, the DOE resource management policy, and Bureau of Land Management land withdrawal actions (McGough, written communication, 1983). In this report, the older configuration boundaries have been used, in part to be consistent with previously published figures. Figure 1-2 is included to show the present configuration for comparison.

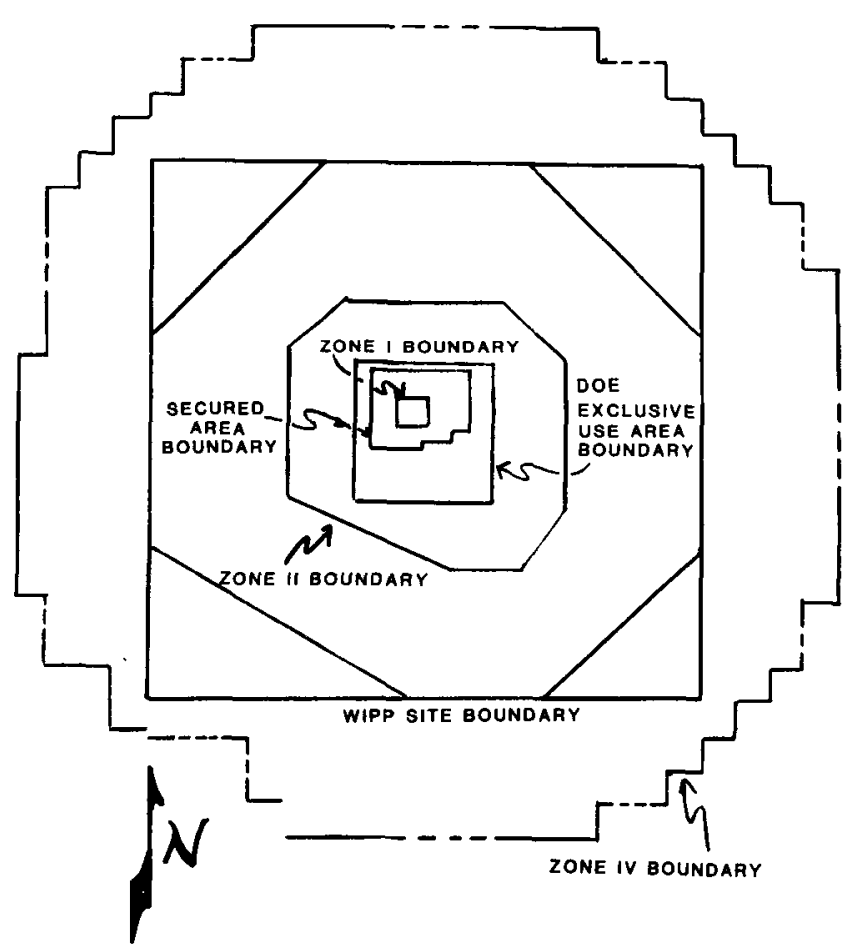

Figure 1-2. Present Configuration of Surface Control Zones at the WIPP Site 
0

0 


\title{
2. General Site Geology
}

\author{
in Deformation of Evaporites Near the WIPP Site
}

by R. P. Snyder

\subsection{Introduction}

The purpose of this portion of the report is to present stratigraphic and structural data and possible explanations to account for the anomalous Castile Formation structures in the northern part of the WIPP site, New Mexico. There are two main sources for the subsurface data used in this chapter: (1) geophysical logs from holes drilled by private companies in the search for oil, gas, and potash, and (2) core and geophysical logs from holes drilled in support of the DOE exploration program in and near the WIPP site.

\subsection{Regional Geologic Setting}

The WIPP site is in southeastern New Mexico, about $25 \mathrm{mi}$ east of Carlsbad (Figure 2-1). It lies in the northern part of the Delaware Basin, an oval-shaped asymmetrical sedimentary trough almost completely bounded by the Capitan reef. The Capitan (north of the WIPP site) is buried, but is exposed southwest of Carlsbad.

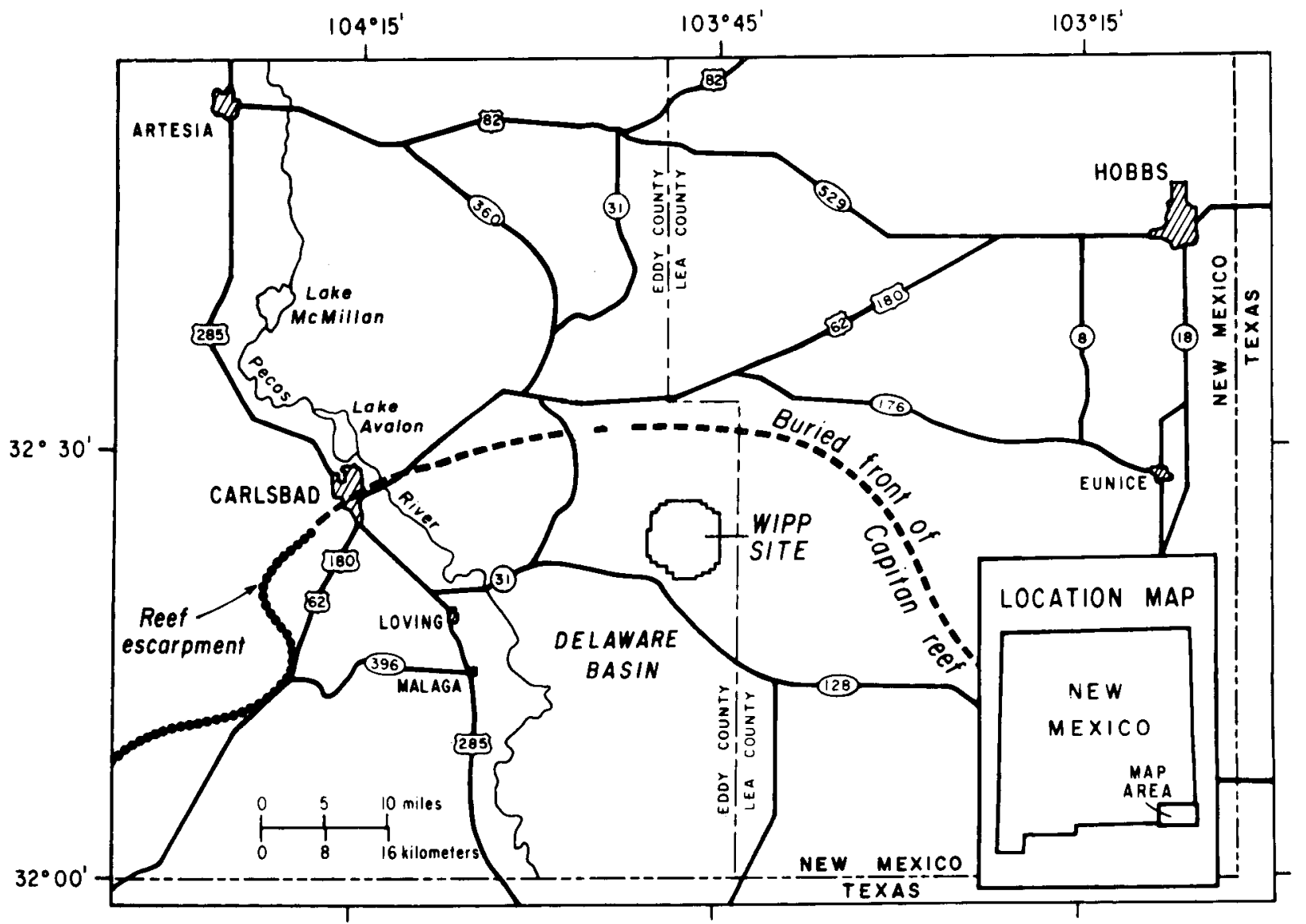

Figure 2-1. Regional Setting, Northern Delaware Basin, Southeastern New Mexico 


\subsection{Stratigraphy and Lithology}

The rocks of interest in this report range in age from Permian to Quaternary. The oldest rocks are those assigned to the Guadalupian Series. This series is further defined as the Delaware Mountain Group consisting of (in ascending order) the Brushy Canyon, Cherry Canyon, and Bell Canyon Formations. Older rocks are described in previous reports by Brokaw et al (1972), Oriel et al (1967), and Powers et al (1978). Figure 2-2 illustrates the stratigraphy in the WIPP area.

\subsubsection{Permian (pre-Ochoan)}

The Delaware Mountain Group underlies the Ochoan Series of the Permian in the Delaware Basin. The uppermost formation, the Bell Canyon, consists of fine-grained sandstones, siltstones and minor limestones and shales in the basin, but near the Capitan, these grade laterally to limestone facies between the reef and the basin. (The Capitan is the reef facies of the Bell Canyon, and for this report is considered the boundary of the report area.)

\subsubsection{Permian (Ochoan)}

The Ochoan Series of the Permian consists of (in ascending order) the Castile, Salado, and Rustler Formations and the Dewey Lake Red Beds. The lower three formations are primarily evaporite deposits, whereas the Dewey Lake is not.

The Castile Formation consists of interlayered anhydrite and halite. Anderson et al (1972) divided the formation into seven units, from the base upward. He designated these units as Anhydrite I (AI), Halite I (HI), Anhydrite II (AII), Halite II (HII), Anhydrite III (AIII), Halite III (HIII), and Anhydrite IV (AIV). All seven of these units are present in the eastern and south-central parts of the basin, but only the lower five (AI through AIII, HI, and HII) are present in the area of the WIPP site.

The Salado Formation overlies the Castile. The contact is conformable and gradational (Jones, 1973), and is defined to be at the horizon where dominant anhydrite gives way upward to halite. In the WIPP area, this contact is generally very sharp. There are three informal units of the Salado; from the base upward they are the lower member, the McNutt potash zone (local usage), and the upper member. The formation contains several thin beds of anhydrite and polyhalite and these beds are numbered and referred to as marker beds (Jones et al, 1960). A thin silty unit, the Vaca Triste Sandstone (Adams, 1944) is the dividing unit between the upper and middle members; Marker Bed 126 (MB126) is the base of the middle member. The middle member, the McNutt potash zone, contains minable quantities of potash; the upper and lower members contain no potash. Halite constitutes $85 \%$ to $90 \%$ of the formation in the WIPP area. Additional descriptions of the Salado and the other formations can be found in Bachman (1980), Jones (1973) and Powers et al (1978).

Overlying the Salado in conformable contact is the Rustler Formation, a unit of alternating beds of siltstone, anhydrite, and halite. Two dolomite beds, the Culebra Dolomite Member and the Magenta Dolomite Member, divide the formation into recognizable units. In ascending order, they are the lower unnamed member (siltstone, gypsum, and anhydrite), the Culebra Dolomite, the Tamarisk Member (halite, anhydrite, and traces of polyhalite), the Magenta Dolomite, and the Forty-Niner Member (anhydrite and siltstone). Where the formation is buried and protected from the surface and subsurface solution, the three nondolomite members contain thin to thick beds of halite.

Conformably overlying the Rustler are the Dewey Lake Red Beds, a thick sequence of reddish-brown siltstones. The Dewey Lake is the uppermost of the Ochoan (Permian) rocks in the Delaware Basin. In the subsurface the unit lies directly on a thick anhydrite of the Rustler. The siltstone layers show horizontal laminations and small-scale cross-laminations. Secondary veins and cross-cutting dikelets of selenite (gypsum) along with greenish-gray alteration spots (reduced iron) give the formation a distinct appearance.

\subsubsection{Triassic}

Overlying the Permian rocks in low-angle unconformity are conglomeratic sandstones and siltstones of the Santa Rosa Sandstone of Triassic age. The Santa Rosa in some places is indistinguishable from the overlying Chinle Formation. Both of these formations comprise the Dockum Group. Because of the generally thin layer of Triassic rock in the vicinity of the WIFP site, it is believed that the only Triassic rocks present are those of the Santa Rosa, the Chinle having been removed by erosion. In this report the term "Santa Rosa" is used. 


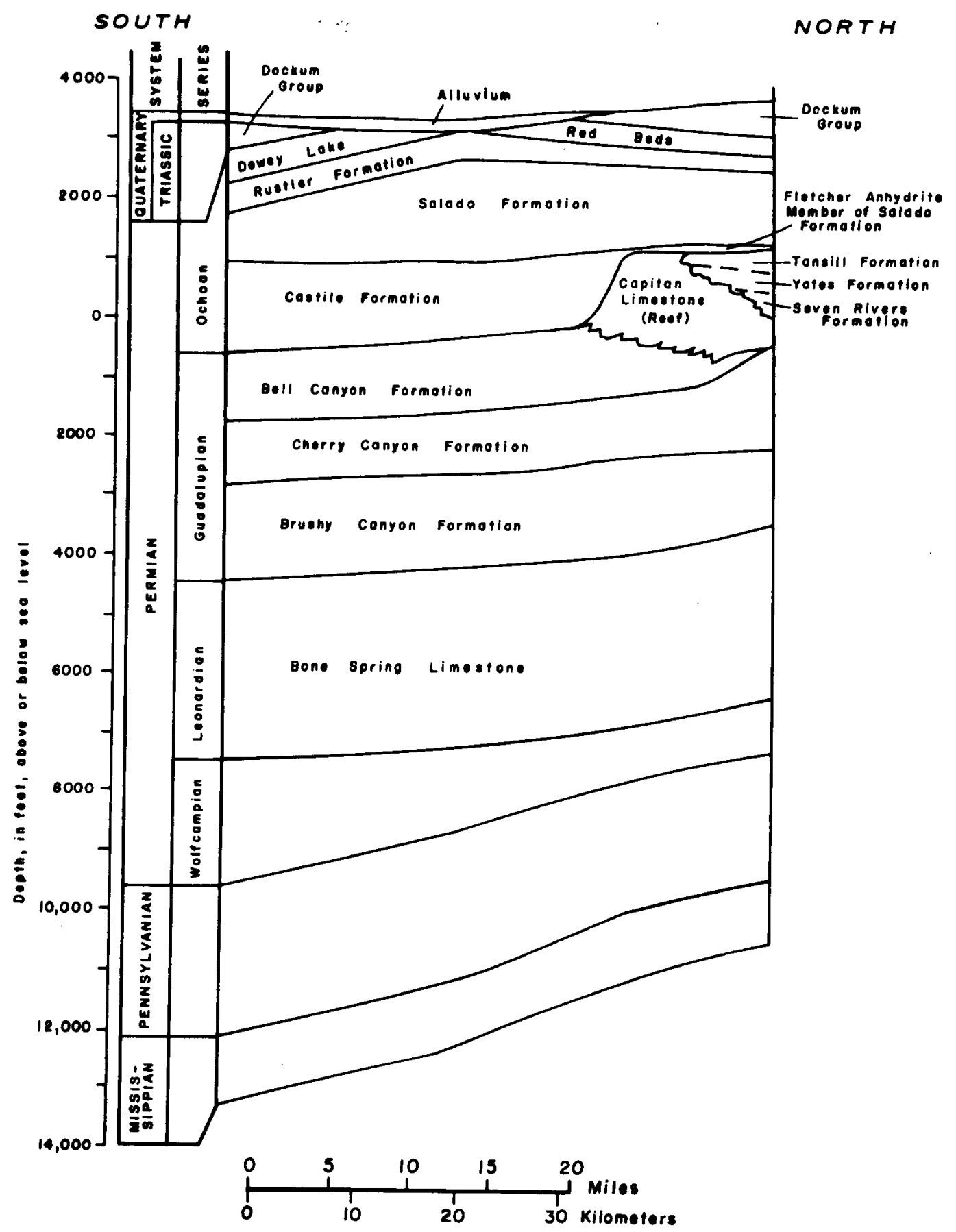

Figure 2-2. Generalized North-South Cross Section, Southeastern New Mexico 


\subsubsection{Jurassic and Cretaceous}

No rocks of these ages have been recognized or mapped in the WIPP site vicinity. Some small outcrops of rocks of Cretaceous age have been mapped along the Pecos River drainage system west of the WIPP site (Bachman, 1980). The Jurassic and Cretaceous periods were evidently times of emergence, and as such, no widespread deposition occurred during these times.

\subsubsection{Tertiary}

No Tertiary rocks have been identified or mapped near the WIPP site. About $6 \mathrm{mi}$ east of the northeast corner of the site scattered outcrops of the Ogallala Formation can be found. The Ogallala of Pliocene age consists of fine- to medium-grain calcareous sandstone, and minor lenses of conglomerate. The formation is capped by a resistant layer of caliche. Although not recognizable at the WIPP site, the Ogallala is important because it is the oldest formation not structurally affected by movement of halite in the Castile (Jones, 1973, p 28).

\subsubsection{Quaternary}

The Gatuna Formation of Quaternary age is a flood-plain deposit and, because it was laid down on a beveled surface, some of the constituents of the beds are from nearby Triassic and Tertiary (Ogallala) units. Pebbles from Tertiary igneous rocks of the Sierra Blanca and Capitan Mountains to the northwest are present as well. The Gatuña consists of conglomerates, sandstones, and siltstones, all poorly consolidated. Some massive shale layers are also present. Near the top of the formation on the east side of Nash Draw is a volcanic ash bed that was dated on the basis of mineralogy and fission-track dating as a Pearlette type "0" ash about 600,000 yr old (Bachman, 1980). Above the Gatuña are the Mescalero Caliche, a $3-13 \mathrm{ft}$ (Bachman, 1980) thick unit dated at 410,000 to $510,000 \mathrm{yr}$ old, and windblown sand deposits.

\subsection{Structure and Thickness}

\subsubsection{Regional}

The Delaware Basin is outlined by the nearly continuous Capitan Limestone, a reef deposit that limited rocks of early Ochoan (Permian) age to the basin. In the basin, the underlying Guadalupian Bell Canyon Formation grades laterally into the reef rock and then into the back-reef facies (Seven Rivers, Yates, and Tansill Formations).

\subsubsection{Pre-Ochoan}

The thrust of this report deals generally with rocks younger than the Bell Canyon Formation, but to help understand the following discussion on structure of the Ochoan and younger rocks the structure contour map drawn on the top of the Bell Canyon is shown in Figure 2-3. Numerous drill holes have penetrated the Castile Formation; a few others have penetrated into the lower anhydrite (AI). Locations of, and depths penetrated by, these drill holes are listed in Table 2-1. Geophysical logs (density, gamma-ray) were used to identify the various contacts in the oil and gas holes; core and/or geophysical logs were used in the holes drilled for the WIPP project. Cross sections (Figures 2-4, 2-5, and 2-6) show the suggested structure on the top of the Bell Canyon Formation in the WIPP area as well as structure of the overlying formations.

\subsubsection{Ochoan}

Castile Formation-The fault block shown in the northern part of the WIPP site (Figure 2-7) is hypothesized on estimates of thickness of AI. The three nearest drill holes (WIPP-11, WIPP-12, and WIPP13) penetrated only to the upper part of AI. The upper contact of AI in WIPP-11 is $\sim 250 \mathrm{ft}$ above earlier projections (Snyder, 1982). It is not known whether the block under WIPP-11 was upthrown prior to or after deposition of $\mathrm{AI}$ and possibly younger units of the Castile Formation, because the complete section of $\mathrm{AI}$ was not penetrated. 


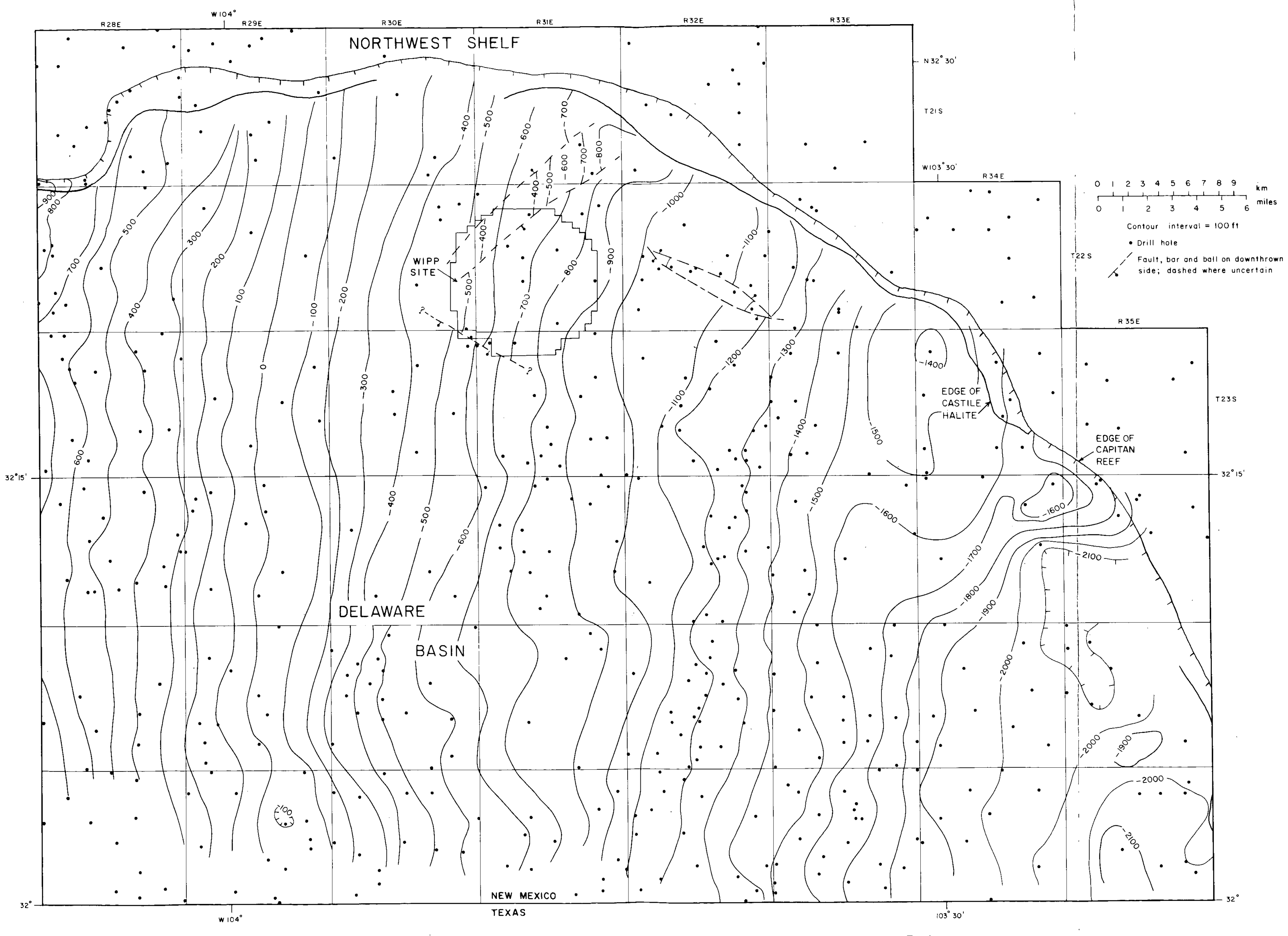

Figure 2-3. Structure Contour Map, Top of Bell Canyon Formation, Northern Part of Delaware Basin 
Table 2-1. Geologic Markers in Exploratory Test Holes

[S, sectlon; T., township. R., range: FSL, from south line: FWL, from north line: FEL, from east line; Fill. from west 1 ine; ND, not Dresent: leaders (...), no data]

\begin{tabular}{|c|c|c|c|c|c|c|c|c|c|c|c|c|c|c|c|}
\hline $\begin{array}{l}\text { Hole.1/ } \\
\text { No.- }\end{array}$ & s. & $\begin{array}{l}\text { Location } \\
\text { T. }\end{array}$ & is. & \multicolumn{3}{|c|}{$\begin{array}{l}\text { coordinates } \\
\text { (feet) }\end{array}$} & \multirow[t]{2}{*}{$\begin{array}{c}\text { Altitude } \\
\text { land surface } \\
\text { (feet) }\end{array}$} & \multirow[t]{2}{*}{$\begin{array}{l}\text { rodtund } \\
\text { Formation }\end{array}$} & \multirow[t]{2}{*}{$\begin{array}{l}\text { Forma } \\
\text { Santa Rosa } \\
\text { Sands tone }\end{array}$} & \multirow[t]{2}{*}{$\begin{array}{l}\text { tion top--1n } \\
\text { Dewey Lake } \\
\text { Red Reds }\end{array}$} & \multirow[t]{2}{*}{$\begin{array}{l}\text { pth in feet } \\
\text { Rustler } \\
\text { Fonmation }\end{array}$} & \multirow[t]{2}{*}{$\begin{array}{l}\text { helow land } \\
\text { Salado } \\
\text { formation }\end{array}$} & \multirow[t]{2}{*}{$\begin{array}{l}\text { surface) } \\
\text { Castile } \\
\text { Formation }\end{array}$} & \multirow[t]{2}{*}{$\begin{array}{l}\text { Pell Canyon } \\
\text { Formation }\end{array}$} & \multirow[t]{2}{*}{$\begin{array}{l}\text { Total } \\
\text { depth }\end{array}$} \\
\hline eologt & ist & holes 1 & DOE I: & & & & & & & & & & & & \\
\hline $\begin{array}{l}\text { ERDA-6 } \\
\text { AEC-8 } \\
\text { ERDA-9 } \\
\text { WIPP-11 } \\
\text { WIPP-12 } \\
\text { WIPP-13 } \\
\text { WIPP-18 } \\
\text { WIPP -19 } \\
\text { WIPP-21 } \\
\text { WIPP-22 } \\
\text { WIPP-33 } \\
\text { WIPP-34 } \\
\text { AEC -7 } \\
\text { DOE-1 }\end{array}$ & $\begin{array}{r}35 \\
11 \\
20 \\
9 \\
17 \\
17 \\
20 \\
20 \\
20 \\
20 \\
13 \\
9 \\
31 \\
28\end{array}$ & $\begin{array}{ll}21 & 5 \\
22 & 5 \\
22 & 5 \\
22 & 5 \\
22 & 5 \\
22 & 5 \\
22 & 5 \\
22 & 5 \\
22 & 5 \\
22 & 5 \\
22 & 5 \\
22 & 5 \\
21 & 5 \\
22 & 5\end{array}$ & $\begin{array}{ll}31 & E \\
31 & E \\
31 & E \\
31 & E \\
31 & E \\
31 & E \\
31 & E \\
31 & E \\
31 & E \\
31 & E \\
30 & E \\
31 & E \\
32 & E \\
31 & F\end{array}$ & $\begin{array}{r}2.152 \mathrm{~F} \\
935 \mathrm{FI} \\
267 \mathrm{~F} \\
712 \mathrm{~F} \\
149 \mathrm{~F} \\
2.566 \mathrm{~F} \\
984 \mathrm{~F} \\
2.987 \mathrm{~F} \\
1.451 \mathrm{~F} \\
2.544 \mathrm{~F} \\
1.762 \mathrm{~F} \\
202 \mathrm{~F} \\
2.035 \mathrm{~F} \\
180 \mathrm{~F}\end{array}$ & $\begin{array}{l}F S L \\
F N L \\
F S L \\
F N L \\
F S L \\
F S L \\
F W L \\
F S L \\
F S L \\
F S L \\
F S L \\
F S L \\
F M L \\
F S L\end{array}$ & $\begin{array}{r}910 \mathrm{FEL} \\
1.979 \mathrm{FHL} \\
177 \mathrm{FEL} \\
294 \mathrm{FHL} \\
82 \mathrm{FEL} \\
1,731 \mathrm{FEL} \\
11 \mathrm{FEL} \\
13 \mathrm{FEL} \\
12 \mathrm{FEL} \\
11 \mathrm{FEL} \\
2.430 \mathrm{FWL} \\
2,000 \mathrm{FWL} \\
2,035 \mathrm{FEL} \\
608 \mathrm{FEL}\end{array}$ & $\begin{array}{l}3,540.2 \\
3,531.5 \\
3,408.9 \\
3,426.1 \\
3,471.5 \\
3,405.4 \\
3,456.5 \\
3,433.1 \\
3,417.0 \\
3,425.8 \\
3.323 .2 \\
3.432 .7 \\
3.656 \\
3.465\end{array}$ & $\begin{array}{l}\text { NP } \\
\text { NP } \\
15 \\
13 \\
\text { NP } \\
\text { NP } \\
\text { NP } \\
\text { NP } \\
12 \\
20 \\
5 \\
\text { NP } \\
\text { NP } \\
\text { NP }\end{array}$ & $\begin{array}{r}17 \\
17 \\
42 \\
29 \\
0 \\
13 \\
9 \\
14 \\
39 \\
25 \\
\text { NP } \\
10 \\
0 \\
38\end{array}$ & $\begin{array}{r}72 \\
168 \\
51 \\
161 \\
155 \\
66 \\
139 \\
96 \\
73 \\
90 \\
34 \\
154 \\
125 \\
125\end{array}$ & $\begin{array}{l}538 \\
662 \\
538 \\
663 \\
628 \\
517 \\
613 \\
589 \\
560 \\
573 \\
401 \\
657 \\
562 \\
560\end{array}$ & $\begin{array}{l}\text { R11 } \\
982 \\
949 \\
951 \\
955 \\
846 \\
928 \\
894 \\
868 \\
883 \\
670 \\
973 \\
989 \\
967\end{array}$ & 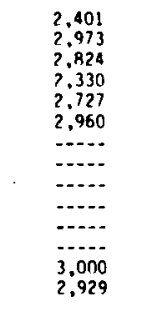 & 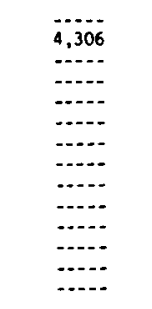 & $\begin{array}{l}2,775 \\
4,913 \\
2,877 \\
3,580 \\
2,774 \\
3,848 \\
1,060 \\
1,038 \\
1,045 \\
1,450 \\
1,840 \\
1,819 \\
4,734 \\
4,063\end{array}$ \\
\hline \multicolumn{16}{|c|}{ Hydrologic test holes IDOE.: } \\
\hline $\begin{array}{l}H-1 \\
H-2 a \\
H-2 b \\
H-2 c \\
H-3 \\
H-4 a \\
H-4 b \\
H-4 c \\
H-5 a \\
H-5 b \\
H-5 c \\
H-6 a \\
H-6 b \\
H-6 c\end{array}$ & $\begin{array}{r}29 \\
29 \\
29 \\
29 \\
29 \\
5 \\
5 \\
5 \\
15 \\
15 \\
15 \\
18 \\
18 \\
18\end{array}$ & $\begin{array}{ll}22 & 5 \\
22 & 5 \\
22 & 5 \\
22 & 5 \\
22 & 5 \\
23 & 5 \\
23 & 5 \\
23 & 5 \\
22 & 5 \\
22 & 5 \\
22 & 5 \\
22 & 5 \\
22 & 5 \\
22 & 5\end{array}$ & $\begin{array}{ll}31 & E \\
31 & E \\
31 & E \\
31 & E \\
31 & E \\
31 & E \\
31 & E \\
31 & E \\
31 & E \\
31 & E \\
31 & E \\
31 & E \\
31 & E \\
31 & E\end{array}$ & $\begin{array}{r}624 \mathrm{~F} \\
722 \mathrm{~F} \\
696 \mathrm{~F} \\
637 \mathrm{~F} \\
2,085 \mathrm{~F} \\
546 \mathrm{~F} \\
498 \mathrm{~F} \\
446 \mathrm{~F} \\
1,092 \mathrm{~F} \\
1.038 \mathrm{~F} \\
1.006 \mathrm{~F} \\
283 \mathrm{~F} \\
196 \mathrm{~F} \\
281 \mathrm{~F}\end{array}$ & $\begin{array}{l}F N L \\
F N L \\
F N L \\
F N L \\
F S L \\
F N L \\
F F L \\
F N L \\
F N L \\
F N L \\
F M L \\
F N L \\
F N L \\
F N L\end{array}$ & $\begin{array}{r}1,086 \mathrm{FEL} \\
1,693 \mathrm{FWL} \\
1,660 \mathrm{FHL} \\
1,708 \mathrm{FHL} \\
138 \mathrm{FEL} \\
720 \mathrm{FWL} \\
633 \mathrm{FWL} \\
718 \mathrm{FWL} \\
185 \mathrm{FEL} \\
236 \mathrm{FEL} \\
135 \mathrm{FEL} \\
274 \mathrm{FWL} \\
323 \mathrm{FHL} \\
374 \mathrm{FHL}\end{array}$ & $\begin{array}{l}3,397.7 \\
3,377.9 \\
3,377.7 \\
3,377.9 \\
3,389.5 \\
3,332.9 \\
3,332.8 \\
3,333.5 \\
3,506.2 \\
3,506.0 \\
3,506.4 \\
3,347.3 \\
3,347.6 \\
3,347.9\end{array}$ & 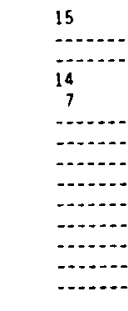 & $\begin{array}{l}\text { NP } \\
\text { NP } \\
\text { NP } \\
\end{array}$ & $\begin{array}{l}35 \\
38 \\
20\end{array}$ & 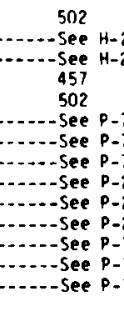 & 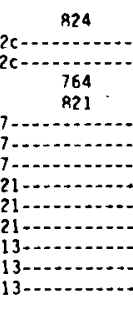 & - & 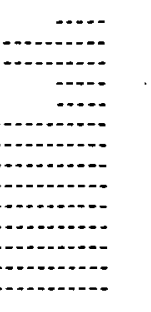 & $\begin{array}{l}856 \\
563 \\
661 \\
796 \\
902 \\
415 \\
529 \\
661 \\
824 \\
925 \\
1.076 \\
525 \\
640 \\
741\end{array}$ \\
\hline \multicolumn{16}{|c|}{ Potash resource test noles $(00 E)$ : } \\
\hline $\begin{array}{l}P-1 \\
P-2 \\
P-3 \\
P-4 \\
P-5 \\
P-6 \\
P-7 \\
P-8 \\
P-9 \\
P-10 \\
P-11 \\
P-12 \\
P-13 \\
P-14 \\
P-15 \\
P-16 \\
P-17 \\
P-18 \\
P-19 \\
P-20 \\
P-21\end{array}$ & $\begin{array}{r}29 \\
28 \\
20 \\
28 \\
17 \\
30 \\
5 \\
4 \\
33 \\
26 \\
23 \\
24 \\
18 \\
24 \\
31 \\
5 \\
4 \\
26 \\
23 \\
14 \\
15\end{array}$ & $\begin{array}{ll}22 & 5 \\
22 & 5 \\
22 & 5 \\
22 & 5 \\
22 & 5 \\
22 & 5 \\
23 & 5 \\
23 & 5 \\
22 & 5 \\
22 & 5 \\
22 & 5 \\
22 & 5 \\
22 & 5 \\
22 & 5 \\
22 & 5 \\
23 & 5 \\
23 & 5 \\
22 & 5 \\
22 & 5 \\
22 & 5 \\
22 & 5\end{array}$ & $\begin{array}{ll}31 & E \\
31 & E \\
31 & E \\
31 & E \\
31 & E \\
31 & E \\
31 & E \\
31 & E \\
31 & E \\
31 & E \\
31 & E \\
30 & E \\
31 & E \\
30 & E \\
31 & E \\
31 & E \\
31 & E \\
31 & E \\
31 & E \\
31 & E \\
31 & E\end{array}$ & $\begin{array}{r}328 \\
121 \\
104 \\
149 \\
186 \\
2,509 \\
514 \\
640 \\
1,493 \\
2,341 \\
156 \\
165 \\
110 \\
309 \\
411 \\
939 \\
1,356 \\
139 \\
1,652 \\
801 \\
859\end{array}$ & $\begin{array}{l}F S L \\
F F L \\
F S L \\
F S L \\
F S L \\
F N L \\
F N L \\
F M L \\
F S L \\
F N L \\
F N L \\
F N L \\
F N L \\
F S L \\
F S L \\
F S L \\
F S L \\
F S L \\
F S L \\
F S L \\
F N L\end{array}$ & $\begin{array}{r}552 \mathrm{FWL} \\
171 \mathrm{FEL} \\
2,154 \mathrm{FHL} \\
1,485 \mathrm{FEL} \\
160 \mathrm{FEL} \\
195 \mathrm{FWL} \\
393 \mathrm{FWL} \\
92 \mathrm{FWL} \\
126 \mathrm{FEL} \\
323 \mathrm{FWL} \\
183 \mathrm{FWL} \\
198 \mathrm{FEL} \\
147 \mathrm{FWL} \\
613 \mathrm{FWL} \\
190 \mathrm{FWL} \\
1,647 \mathrm{FHL} \\
398 \mathrm{FWL} \\
733 \mathrm{FEL} \\
2.335 \mathrm{FWL} \\
799 \mathrm{FEL} \\
130 \mathrm{FEL}\end{array}$ & $\begin{array}{l}3,345.1 \\
3,479.7 \\
3,382.7 \\
3,443.8 \\
3,470.9 \\
3,354.1 \\
3,332.0 \\
3,338.6 \\
3,411.5 \\
3,509.3 \\
3,503.9 \\
3.373 .6 \\
3,345.2 \\
3,359.6 \\
3,309.5 \\
3,317.9 \\
3,335.9 \\
3,477.2 \\
3,545.1 \\
3,552.7 \\
3,509.0\end{array}$ & $\begin{array}{l}10 \\
18 \\
10 \\
\text { NP } \\
\text { NP } \\
8 \\
11 \\
9 \\
\text { NP } \\
\text { NP } \\
\text { NP } \\
\text { NP } \\
12 \\
10 \\
11 \\
14 \\
14 \\
\text { NP } \\
\text { NP } \\
\text { NP } \\
\text { NP }\end{array}$ & $\begin{array}{c}N P \\
3 R \\
N P \\
R \\
13 \\
13 \\
N P \\
N P \\
N P \\
11 \\
P \\
9 \\
N P \\
N P \\
N P \\
N P \\
N P \\
N P \\
9 \\
R \\
6 \\
8\end{array}$ & $\begin{array}{r}40 \\
164 \\
41 \\
99 \\
146 \\
18 \\
45 \\
39 \\
56 \\
151 \\
224 \\
8 \\
38 \\
42 \\
32 \\
32 \\
46 \\
87 \\
32 \\
261 \\
225\end{array}$ & $\begin{array}{l}358 \\
690 \\
468 \\
609 \\
623 \\
357 \\
312 \\
391 \\
562 \\
686 \\
745 \\
461 \\
427 \\
387 \\
231 \\
316 \\
382 \\
626 \\
758 \\
780 \\
734\end{array}$ & $\begin{array}{r}677 \\
1.008 \\
786 \\
930 \\
947 \\
659 \\
630 \\
715 \\
981 \\
1.086 \\
1.058 \\
749 \\
721 \\
687 \\
542 \\
646 \\
715 \\
1.088 \\
1,117 \\
1.103 \\
1.043\end{array}$ & 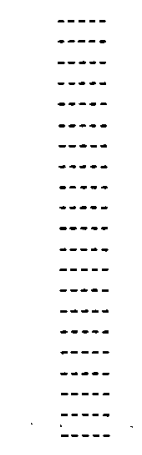 & 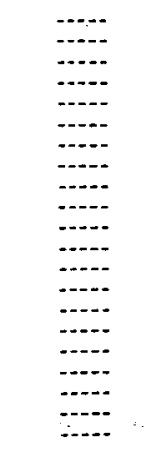 & $\begin{array}{l}1,591 \\
1,895 \\
1,676 \\
1,857 \\
1,830 \\
1,573 \\
1,574 \\
1,660 \\
1,796 \\
2,009 \\
1,940 \\
1,598 \\
1,576 \\
1,545 \\
1,465 \\
1,585 \\
1,660 \\
1,998 \\
2,000 \\
1,995 \\
1,915\end{array}$ \\
\hline \multicolumn{16}{|c|}{ Potash resource test holes (private industry): } \\
\hline $\begin{array}{l}D-48 \\
D-104 \\
0-120 \\
D-121\end{array}$ & $\begin{array}{l}14 \\
24 \\
13 \\
11\end{array}$ & $\begin{array}{ll}22 & 5 \\
22 & 5 \\
22 & 5 \\
22 & 5\end{array}$ & $\begin{array}{l}30 \mathrm{E} \\
30 \mathrm{E} \\
30 \mathrm{E} \\
30 \mathrm{E}\end{array}$ & $\begin{array}{r}136 \\
2,589 \\
1,574 \\
1,747\end{array}$ & $\begin{array}{l}F S L \\
F N L \\
F N L \\
F S I\end{array}$ & $\begin{array}{l}2.179 \mathrm{FEL} \\
1,396 \mathrm{FEL} \\
1,566 \mathrm{FNL} \\
1,301 \mathrm{FWL}\end{array}$ & $\begin{array}{l}3,343.9 \\
3,384.2 \\
3.327 .5 \\
3,307.6\end{array}$ & $\begin{array}{l}\mathrm{NP} \\
\mathrm{NP} \\
\mathrm{MP} \\
10+\end{array}$ & $\begin{array}{l}\text { NP } \\
\text { NP } \\
\text { NP } \\
\text { NP }\end{array}$ & $\begin{array}{c}10+ \\
5 \\
10+ \\
90\end{array}$ & $\begin{array}{l}360 \\
460 \\
360 \\
210\end{array}$ & $\begin{array}{l}635 \\
740 \\
655 \\
53 n\end{array}$ & $\begin{array}{l}\cdots \\
\cdots \cdots \\
\cdots \cdots\end{array}$ & $\begin{array}{l}\cdots \\
\cdots-1 \\
\cdots \cdots\end{array}$ & $\begin{array}{l}1.524 \\
1,597 \\
1,500 \\
1.259\end{array}$ \\
\hline $\begin{array}{l}0-123 \\
0-160 \\
0-179 \\
0-202 \\
0-203 \\
0-207 \\
0-231 \\
0-233 \\
0-234 \\
0-235 \\
0-249 \\
D-2504\end{array}$ & $\begin{array}{r}34 \\
36 \\
2 \\
23 \\
26 \\
19 \\
27 \\
26 \\
26 \\
25 \\
35 \\
35\end{array}$ & $\begin{array}{ll}22 & 5 \\
22 & 5 \\
23 & 5 \\
22 & 5 \\
22 & 5 \\
22 & 5 \\
22 & 5 \\
22 & 5 \\
22 & 5 \\
22 & 5 \\
22 & 5 \\
22 & 5\end{array}$ & $\begin{array}{l}31 \mathrm{E} \\
30 \mathrm{E} \\
30 \mathrm{E} \\
30 \mathrm{E} \\
30 \mathrm{E} \\
31 \mathrm{E} \\
30 \mathrm{E} \\
30 \mathrm{E} \\
30 \mathrm{E} \\
30 \mathrm{E} \\
30 \mathrm{E} \\
30 \mathrm{E}\end{array}$ & $\begin{array}{r}2,615 \\
2,463 \\
2,655 \\
1,235 \\
2,633 \\
1,481 \\
2,365 \\
477 \\
163 \\
2,400 \\
2,624 \\
2,472\end{array}$ & $\begin{array}{l}F S L \\
F S L \\
F M L \\
F S L \\
F M L \\
F S L \\
F S L \\
F M L \\
F S L \\
F H L \\
F M L \\
F M L\end{array}$ & $\begin{array}{r}277 \mathrm{FEL} \\
1,124 \mathrm{FHL} \\
2,655 \mathrm{FEL} \\
1,145 \mathrm{FWL} \\
1,261 \mathrm{FEL} \\
1,330 \mathrm{FWL} \\
222 \mathrm{FEL} \\
27 \mathrm{FWL} \\
667 \mathrm{FZL} \\
806 \mathrm{FWL} \\
306 \mathrm{FWL} \\
2,539 \mathrm{FEL}\end{array}$ & $\begin{array}{l}3,431.9 \\
3,305.5 \\
3,243.8 \\
3,323.3 \\
3,319.4 \\
3,402.7 \\
3,287.5 \\
3,302.1 \\
3,312.0 \\
3,338.6 \\
3,265.5 \\
3,281.9\end{array}$ & $\begin{array}{l}\text { NP } \\
\text { NP } \\
\text { NP } \\
\text { NP } \\
\text { NP } \\
\text { NP } \\
9 \\
\text { NP } \\
\text { NP } \\
-- \\
\text { NP } \\
11\end{array}$ & $\begin{array}{l}10+ \\
\text { NP } \\
\text { NP } \\
\text { NP } \\
\text { NP } \\
\text { NP } \\
\text { NP } \\
\text { MP } \\
\text { NP } \\
-- \\
\text { NP } \\
\text { NP }\end{array}$ & $\begin{array}{l}70 \\
10 \\
5 \pm \\
10 \pm \\
10 \pm \\
10 \pm \\
22 \\
14 \\
13 \\
1 . \\
14 \\
17\end{array}$ & $\begin{array}{l}625 \\
240 \\
110 \\
300 \\
300 \\
460 \\
214 \\
260 \\
259 \\
-150 \\
292\end{array}$ & $\begin{array}{r}987 \\
530 \\
430 \\
590 \\
610 \\
770 \\
518 \\
558 \\
563 \\
-454 \\
496 \\
496\end{array}$ & 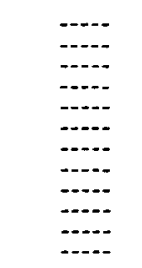 & 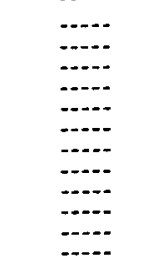 & $\begin{array}{l}1,880 \\
1,354 \\
1,350 \\
1,443 \\
1,443 \\
1,613 \\
1,378 \\
1,406 \\
1,425 \\
1,506 \\
1,346 \\
1,366\end{array}$ \\
\hline $\begin{array}{l}F C-70 \\
F C-81 \\
F C-82 \\
F C-91 \\
F C-92\end{array}$ & $\begin{array}{r}7 \\
3 \\
8 \\
10 \\
8\end{array}$ & $\begin{array}{ll}22 & 5 \\
22 & 5 \\
22 & 5 \\
22 & 5 \\
22 & 5\end{array}$ & $\begin{array}{ll}31 & E \\
31 & E \\
31 & E \\
31 & E \\
31 & E\end{array}$ & $\begin{array}{l}197 \\
166 \\
154 \\
248 \\
143\end{array}$ & $\begin{array}{l}\text { FML } \\
F S L \\
F S L \\
F S L \\
F S L\end{array}$ & $\begin{array}{r}167 \mathrm{FEL} \\
72 \mathrm{FWL} \\
37 \mathrm{FWL} \\
163 \mathrm{FUL} \\
249 \mathrm{FEL}\end{array}$ & $\begin{array}{l}3,382.3 \\
3,470.2 \\
3,380.5 \\
3,449.4 \\
3,420.6\end{array}$ & $\begin{array}{l}15 t \\
N P \\
14 \\
N P \\
N P\end{array}$ & $\begin{array}{l}N P \\
12 \\
N P \\
10 \pm \\
10 \pm\end{array}$ & $\begin{array}{r}90 \\
133 \\
49 \\
160 \\
115\end{array}$ & $\begin{array}{l}501 \\
645 \\
516 \\
660 \\
635\end{array}$ & $\begin{array}{l}800 \\
942 \\
812 \\
956 \\
960\end{array}$ & 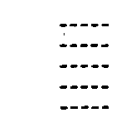 & 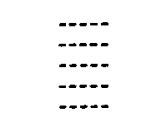 & $\begin{array}{l}1,603 \\
1,735 \\
1,684 \\
1,788 \\
1,818\end{array}$ \\
\hline
\end{tabular}


Table 2-1. (cont)

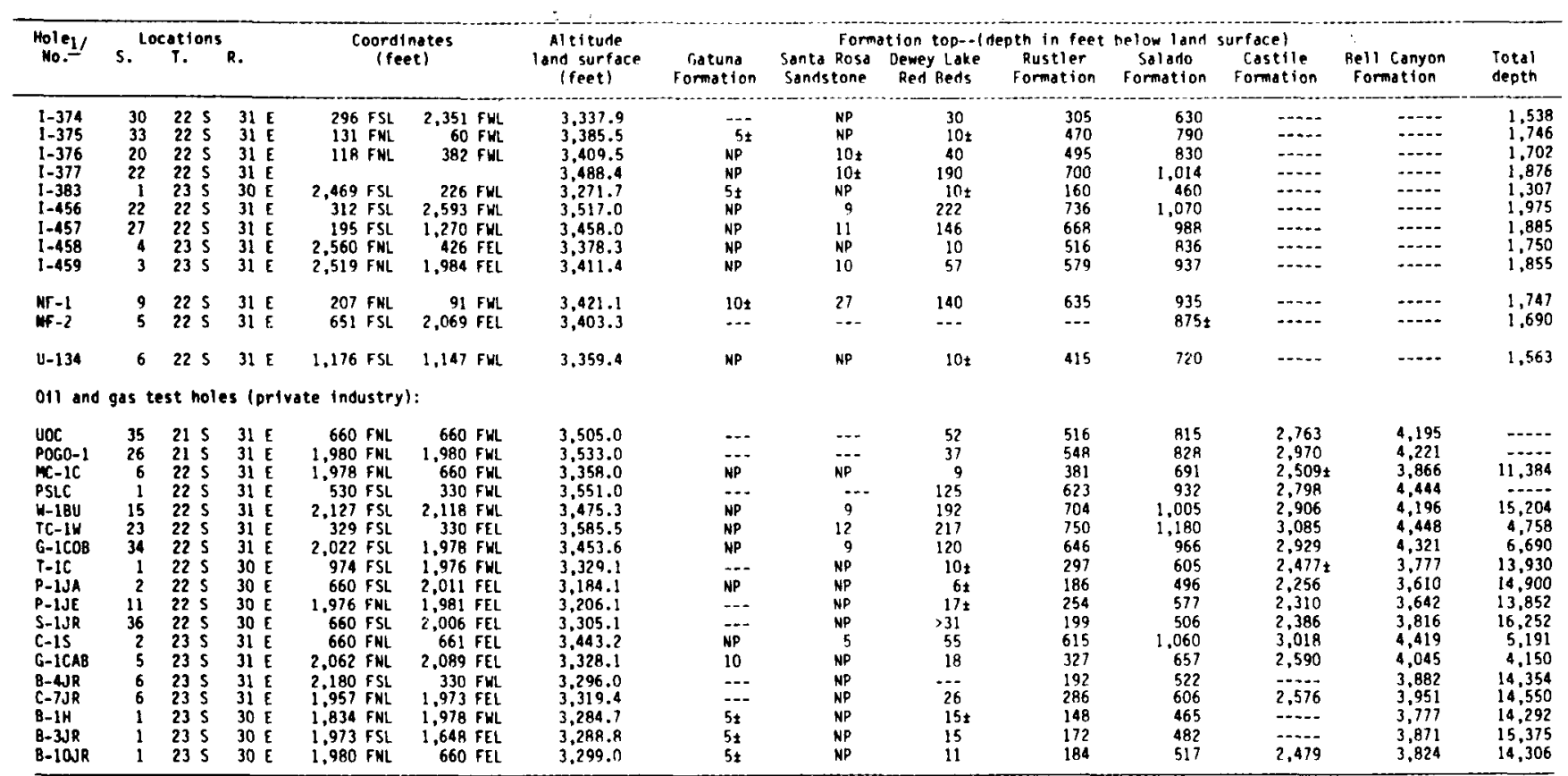

1/Key to abbreviations:

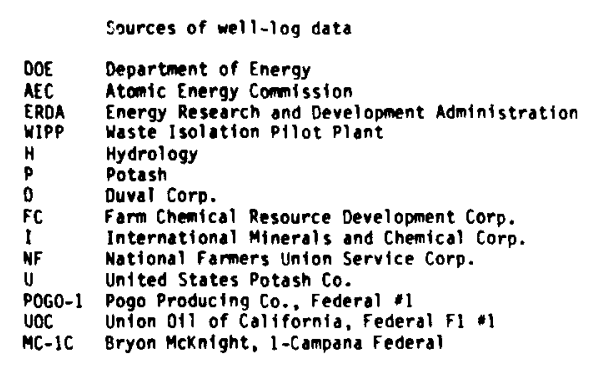

PSLC Pogo Producing Co., SLC Federal ol

W-IBU Clayton W. Williams, Jr., 1-Badger Unit Federal

IC-1W Texas Crude 0il Co., 1-23 Wright

$1-1 \mathrm{COB}$ Michael $P$. Grace, l-Grace Cotton Baby Federal

T-1C Troporo 011 and Gas Co., 1-Cabana

P-iJA Phillips Petroleum Co.. l-James "A"

$P$-iJE Phillips Petroleum Co., 1-James " $\xi$ "

S-1JR Shell oil Co., 1-State James Ranch

C-1S Continental 0il Co.. 1-State, AA-2

[i-1CAB Michael P. Grace, 1 -Cabin Baby Federal
B-4JR Belco Petroleum Corp. 4 James Ranch Unde

C-7JRR Continental O1l Co..; James Ranch Unit

B-1H Belco Petroleum Corp.. I Hudson Federal

B-3JR Belco Petroleum Corp.. 3 James Ranch Unit

B-10.jR Belco Petroleum Corp. 10 James Ranch Unit 
1) Phillips Pet. Co., Sondy Unit \#,

2) Belco Pot. Corp., Jomes Ranch \#10

3) Sholl Oil Co., Jomes Ranch Unit \#1

4) WIPP 13

5) WIPP 11

6) EROA 6

7) Union Oil of California, Federal FI $\# 1$

8) Pogo Producing Co., Federal \#1

9) Frod Turner Jr., AlO Foderal \#1

10) Phillips Pet. Co., Jomes " $C$ " \#1

11) Bryon McKnight, Campana $\# 1$

12) Clayton W. Willioms Jr., Badger Unit Federal 1

13) Texas Crude Oil Co., Wright-Federal \#1-23

14) Rolph Lowe, Bass Federal \#1

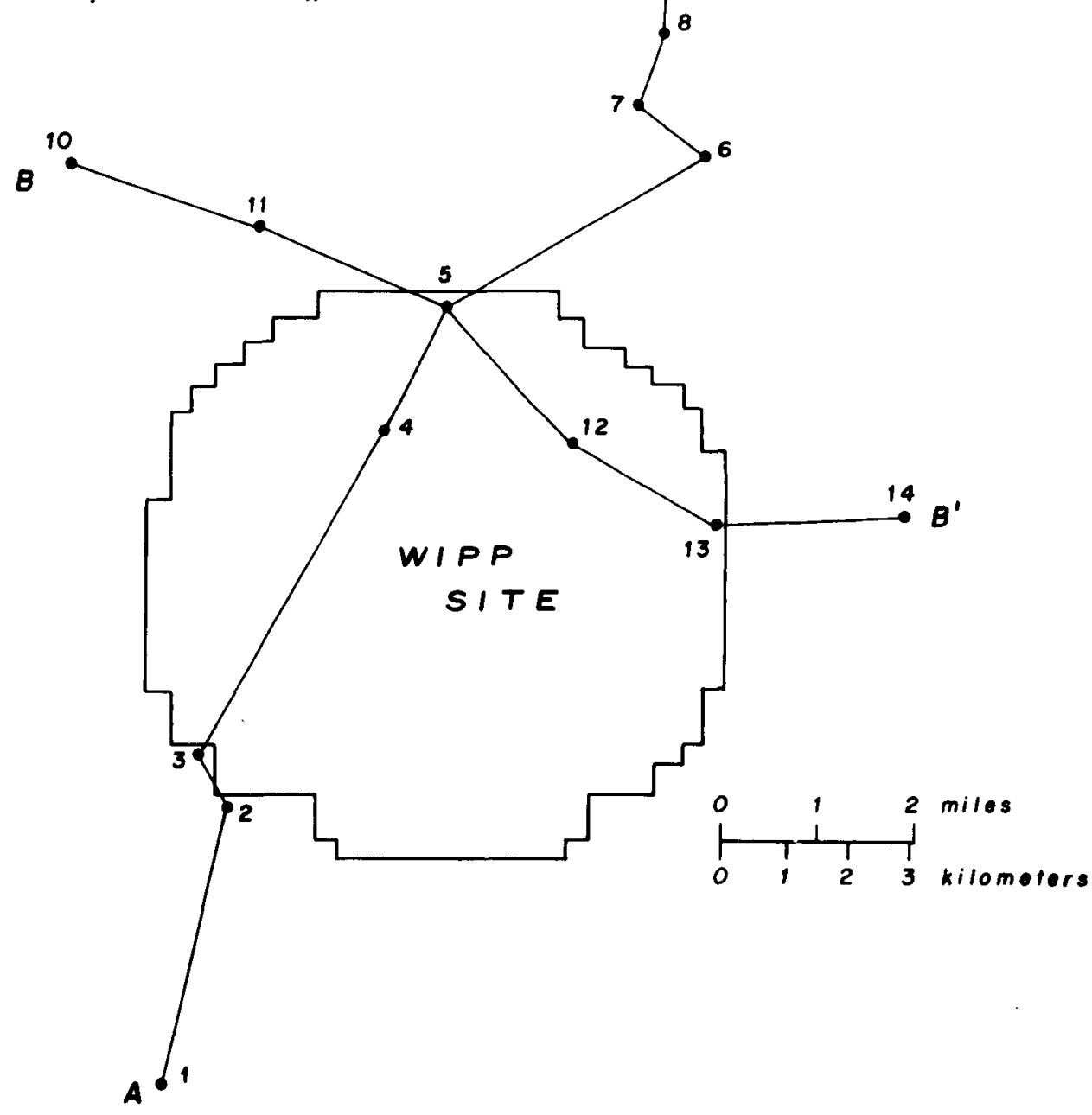

Figure 2-4. Index Map Showing Lines and Drill Holes Used in Cross Sections Shown on Figures 2-5 and 2-6 


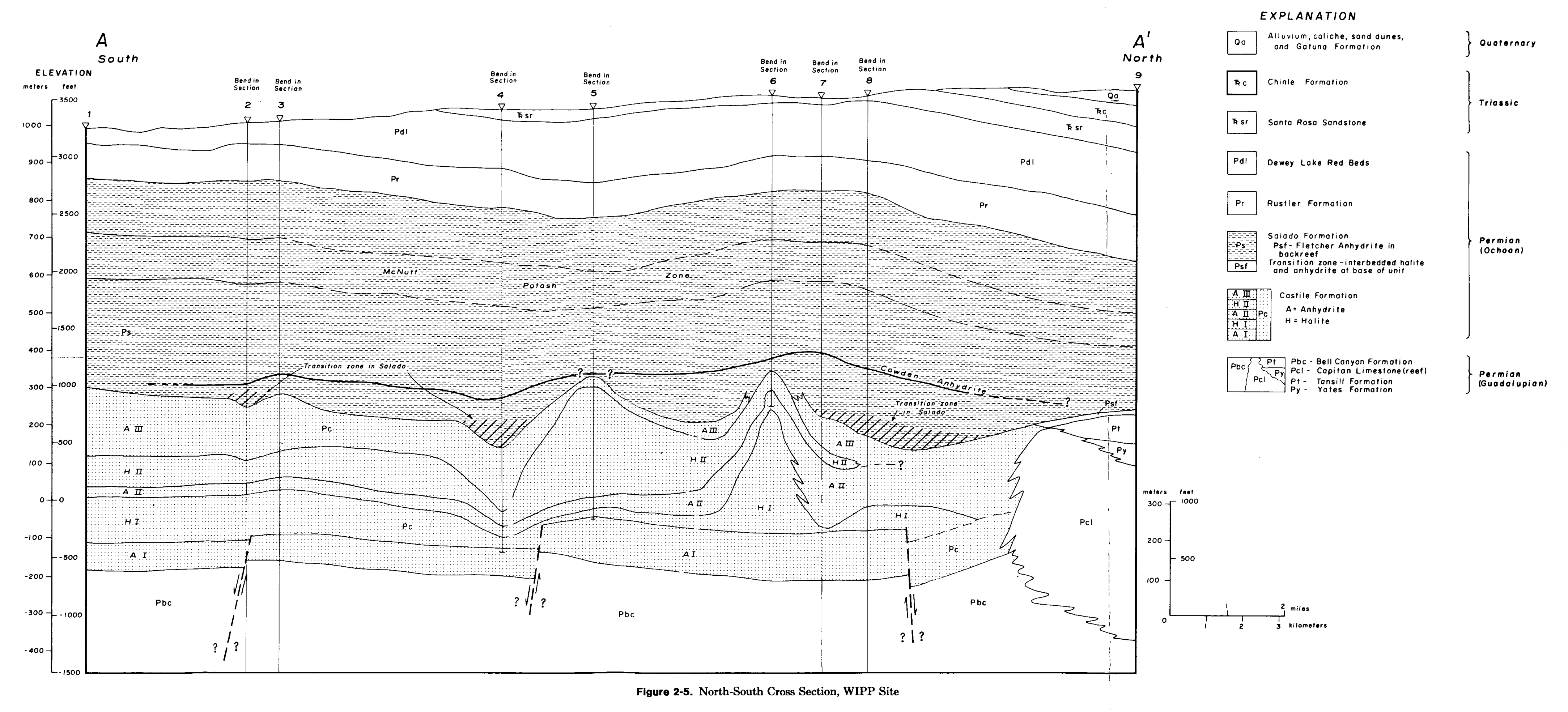




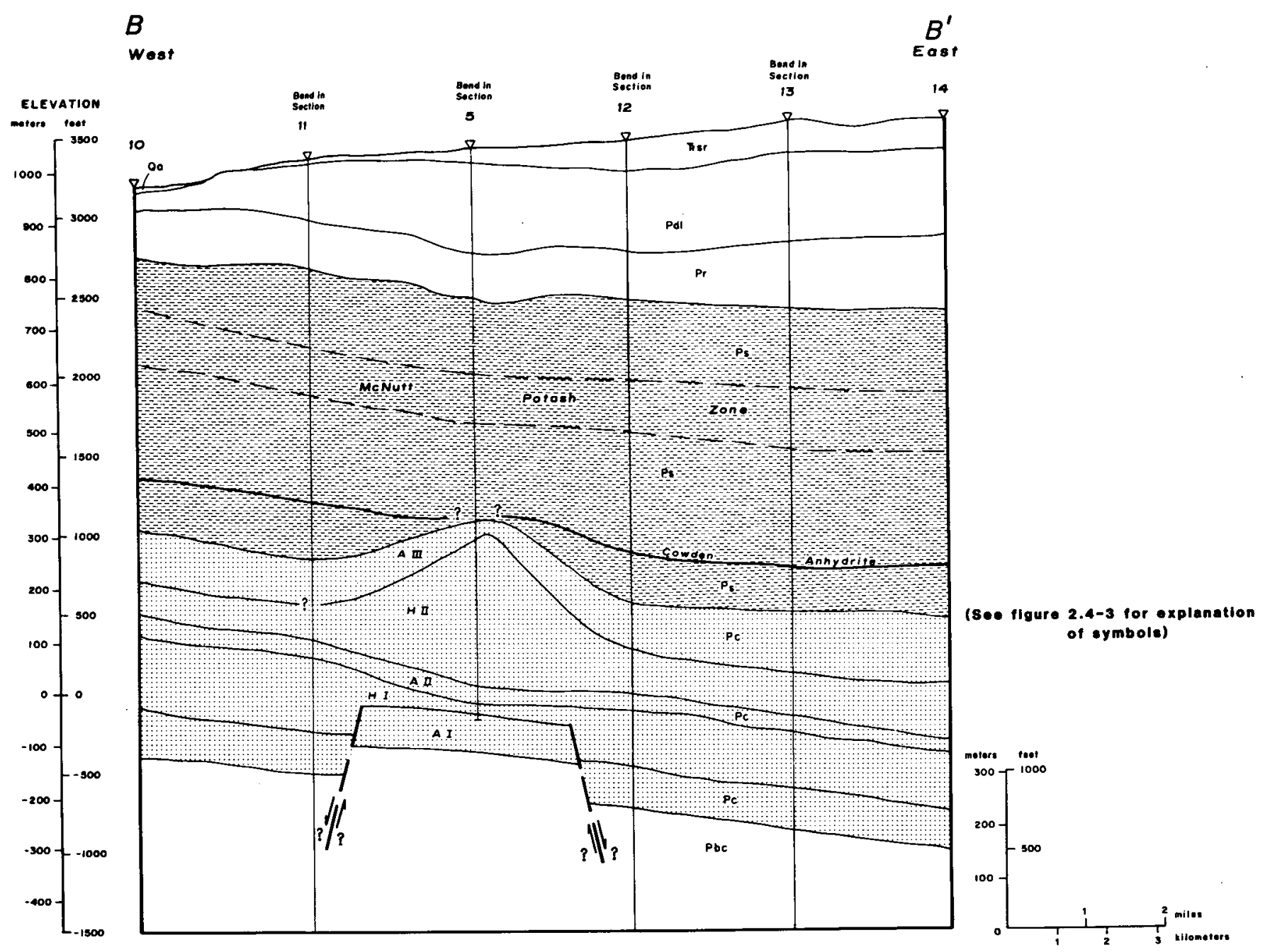

Figure 2-6. East-West Cross Section, WIPP Site 


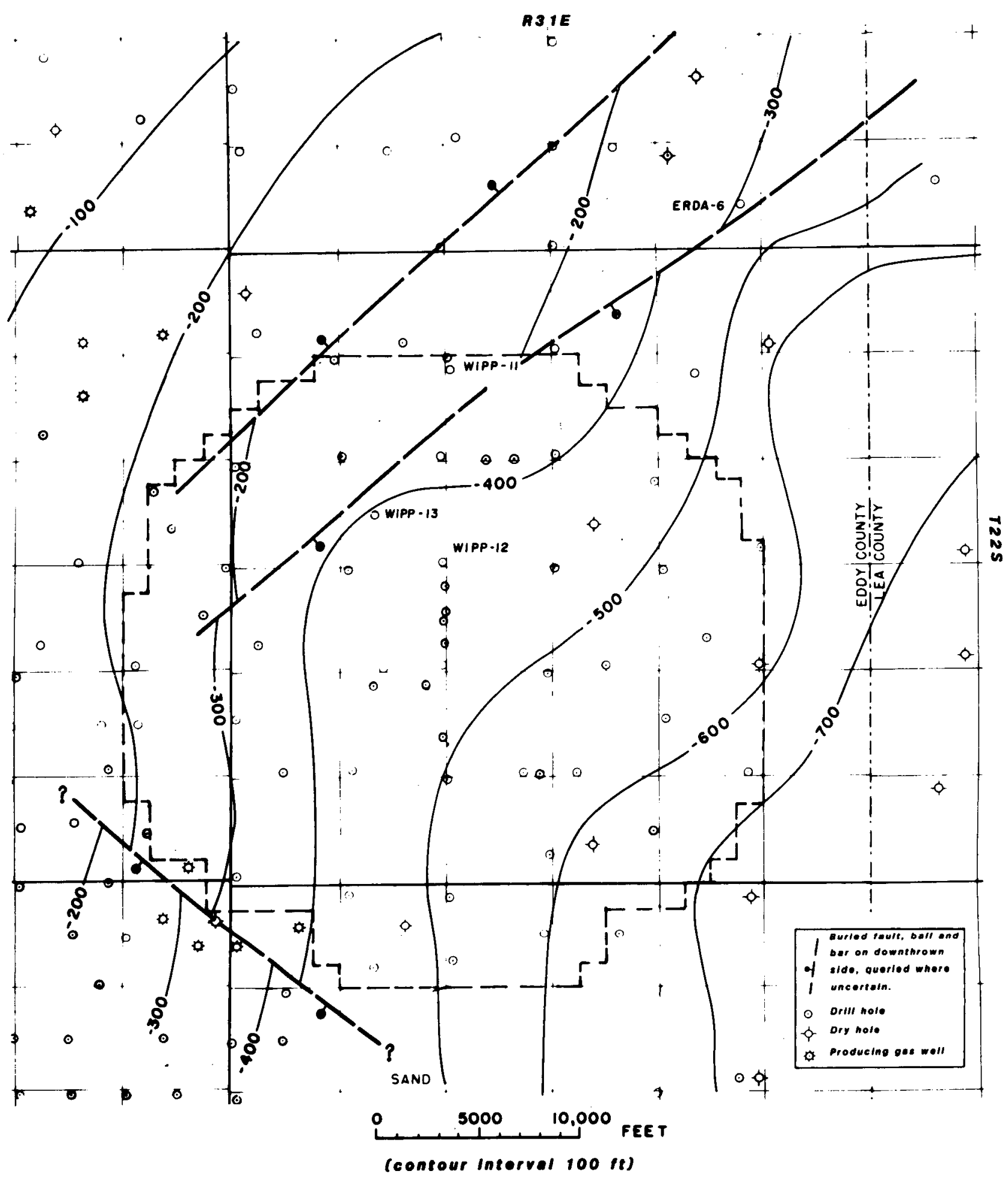

Figure 2-7. Structure Contour Map, Top of Anhydrite Unit AI, Castile Formation 
The northwest-trending fault at the southwest corner of the WIPP site is an interpretation to explain the abnormal thinning of $\mathrm{AI}$ in this area. In one drill hole (B10-JR) the total AI unit penetrated measured only $185 \mathrm{ft}$ thick. Holes nearby have AI thicknesses of $253 \mathrm{ft}(\mathrm{S}-1 \mathrm{JR})$ and $237 \mathrm{ft}$ (G-1CAB). The majority of the structures in and around the WIPP site appear to have been the result of movement of halite (HI and HII) in the Castile.

The structure contour map drawn on the top of AI (Figure 2-7) mirrors the structure on the Bell Canyon Formation.

The structure contour map drawn on the top of $\mathrm{HI}$ (Figure 2-8) shows the beginning of the chaotic distribution of the Castile halites. A broad area at the WIPP-13 drill site appears to be depressed $400 \mathrm{ft}$. Halite I is $94 \mathrm{ft}$ thick in WIPP-13; to the southeast about half a mile, HI is $516 \mathrm{ft}$ thick in WIPP-12. It appears that there has been movement of $\mathrm{HI}$ from the WIPP-13 area to the WIPP-12 area.

Northeast of the WIPP site at the ERDA-6 area, the structure on the top of HI shows a northwesttrending anticline. It appears that halite from HI has moved upward stratigraphically $>1000 \mathrm{ft}$.

The isopach map of HI (Figure 2-9) shows a thinning of HI at the WIPP-13 and WIPP-11 locations, a slight thickening at WIPP-12, and a major thickening at ERDA-6.

Overlying $\mathrm{HI}$ is AII, a generally $110-120$-ft-thick anhydrite layer. The structure contour map drawn on the top of AII (Figure 2-10) is similar to that of HI because this thin anhydrite usually was carried along with the movements of $\mathrm{HI}$ and mimics the HI structure. The surface of Halite II (Figure 2-11) overlying AII, also shows a low in the area of WIPP-13 and a high at ERDA-6. Additionally, there is an oval high in the WIPP-11 area. It appears that halite from HII has moved from the areas of WIPP-13 and ERDA-6 toward WIPP-11. The cross section (Figure 2-4) shows the interpretation of this. The isopach map (Figure 2-12) of HII shows that the majority of the halite that moved toward WIPP-11 came from the area of WIPP13 and from the area between WIPP-11 and ERDA-6.

The structure on the top of the Castile Formation is shown in Figure 2-13. The three major areas, highs at WIPP-11 and ERDA-6 and a low at WIPP-13, are apparent although there is some muting of the structures. The AIII isopach map (Figure 2-14) shows some interesting features. The thickness of AIII at WIPP13 is excessive. Core from the drill hole shows dips of $45^{\circ}$ or more on the laminations. The cross section (Figure 2-4) depicts the low point of the base of AII to be located at WIPP-13. This is probably not the case; the low point of the base may be offset to one side or the other. Obviously, the cored thickness is not the true depositional thickness; the true thickness of AIII at WIPP-13 is probably 350 to $400 \mathrm{ft}$.

At WIPP-11, AIII is $\sim 200 \mathrm{ft}$ thinner than normal (Figure 2-14). This may be due in part to stretching of the anhydrite as HII rose underneath and in part to nondeposition as HII may have been rising prior to deposition of AIII. In the ERDA- 6 area the structure has been interpreted as a diapir. AIII has been breached by the upwelling of the underlying HI (Figure 2-4). This interpretation of stretching and consequent thinning of AII had previously been made by Anderson and Powers (1978).

Salado Formation-The Salado Formation contains many thin beds of anhydrite and polyhalite, some of which have been used in this report in the construction of structure and isopach maps. A $30-\mathrm{ft}-$ thick anhydrite bed, the Cowden Anhydrite, in the lower unnamed member of the Salado, is one of these beds. Other markers used are the base of Marker Bed 126 and the top of the Vaca Triste Sandstone. These last two units divide the Salado into three units: the unnamed lower member, the McNutt potash zone (local usage), and the unnamed upper member.

The structure contour map drawn on the base of the Cowden Anhydrite (Figure 2-15) shows a remarkably smooth surface when compared with the previous structure maps of the various units in the Castile Formation. There is a low at the WIPP-13 area, not much structure at the WIPP-11 area, and a broad southeast-plunging nose at ERDA-6. Southwest of the WIPP site there is a small oblong high.

The isopach of the interval between the base of the Cowden and the top of the Castile (Figure 2-16) when compared with the structure contour map of the top of the Castile (Figure 2-13) looks as if the interval was deposited on already-existing and still-developing structures and deposition of the interval tended to level out the hundreds of feet of structure on the Castile Formation.

The structure of the top of the lower unnamed member of the Salado (Figure 2-17) bears almost no resemblance to the structure maps of the underlying units. There is a very slight high at the WIPP-11 site and an oblong northwest-trending high at ERDA-6. The small closed high off the southwest corner of the WIPP site is still evident. Most of the structural highs and lows seen on underlying surfaces have disappeared. Instead, a very broad northeast-plunging synclinal surface has developed in the eastern half of the site. 


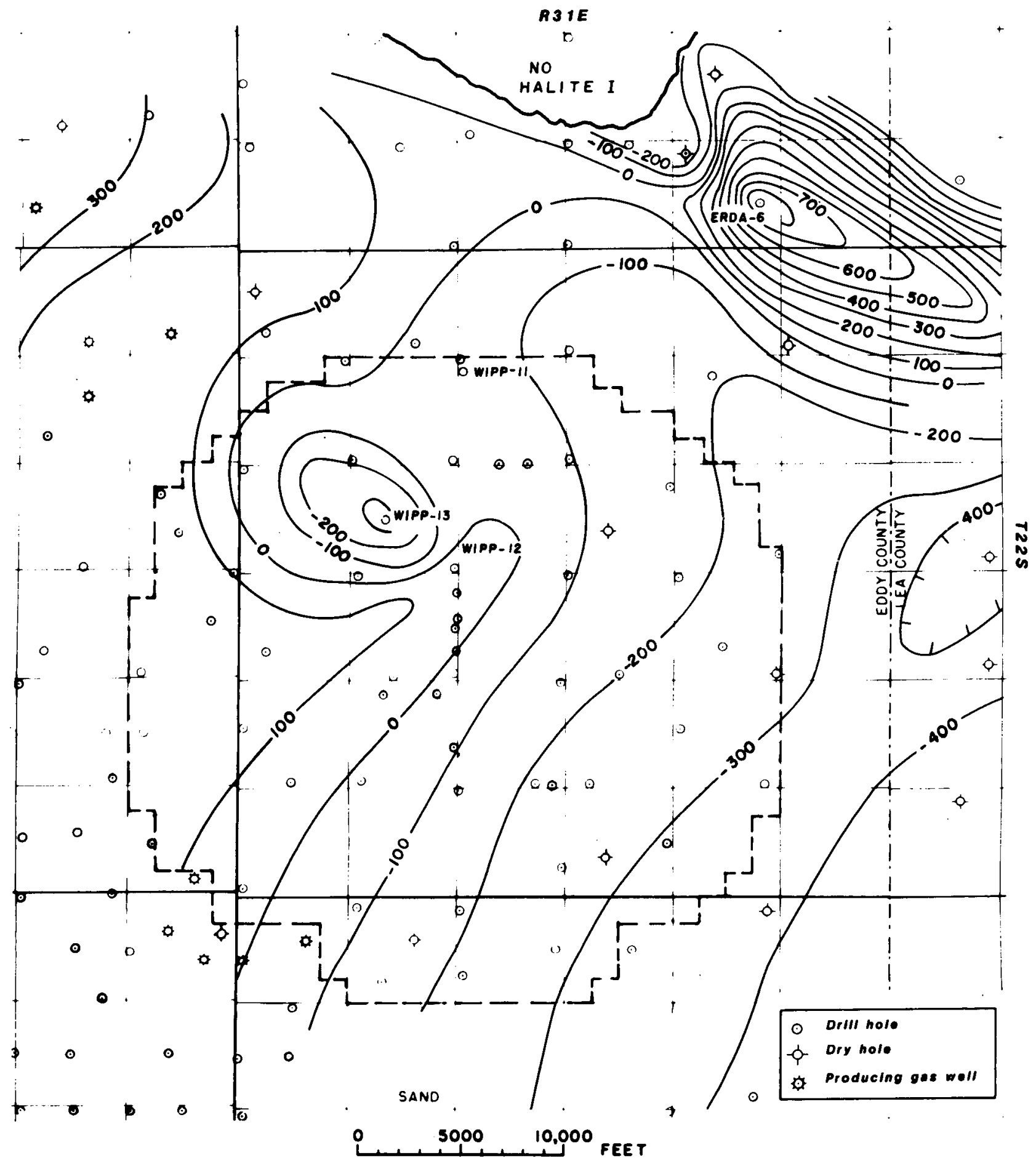

(contour Interval toort; hachures Indleate closed low)

Figure 2-8. Structure Contour Map, Top of Halite Unit HI, Castile Formation 
uo!ฺeuso

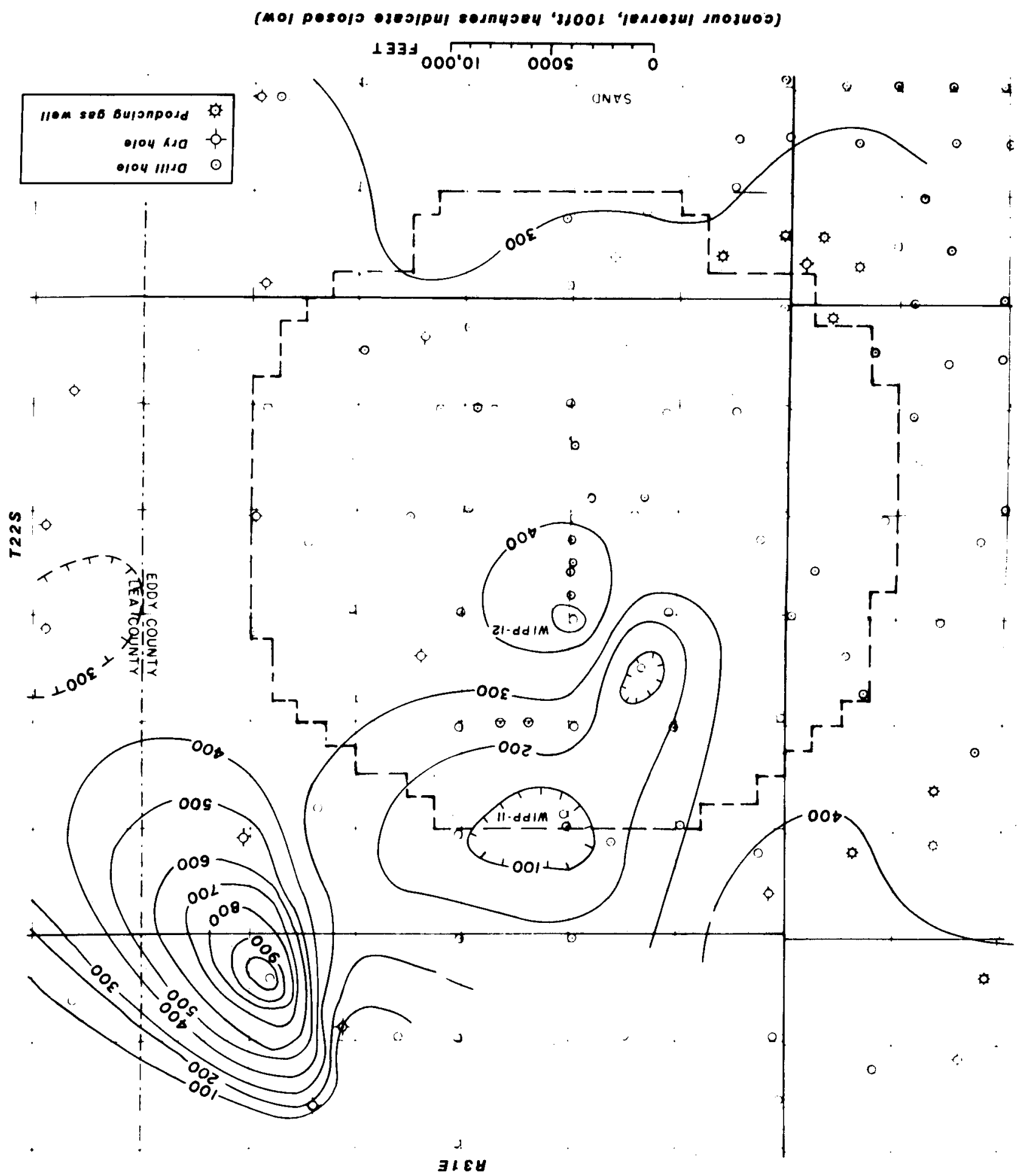




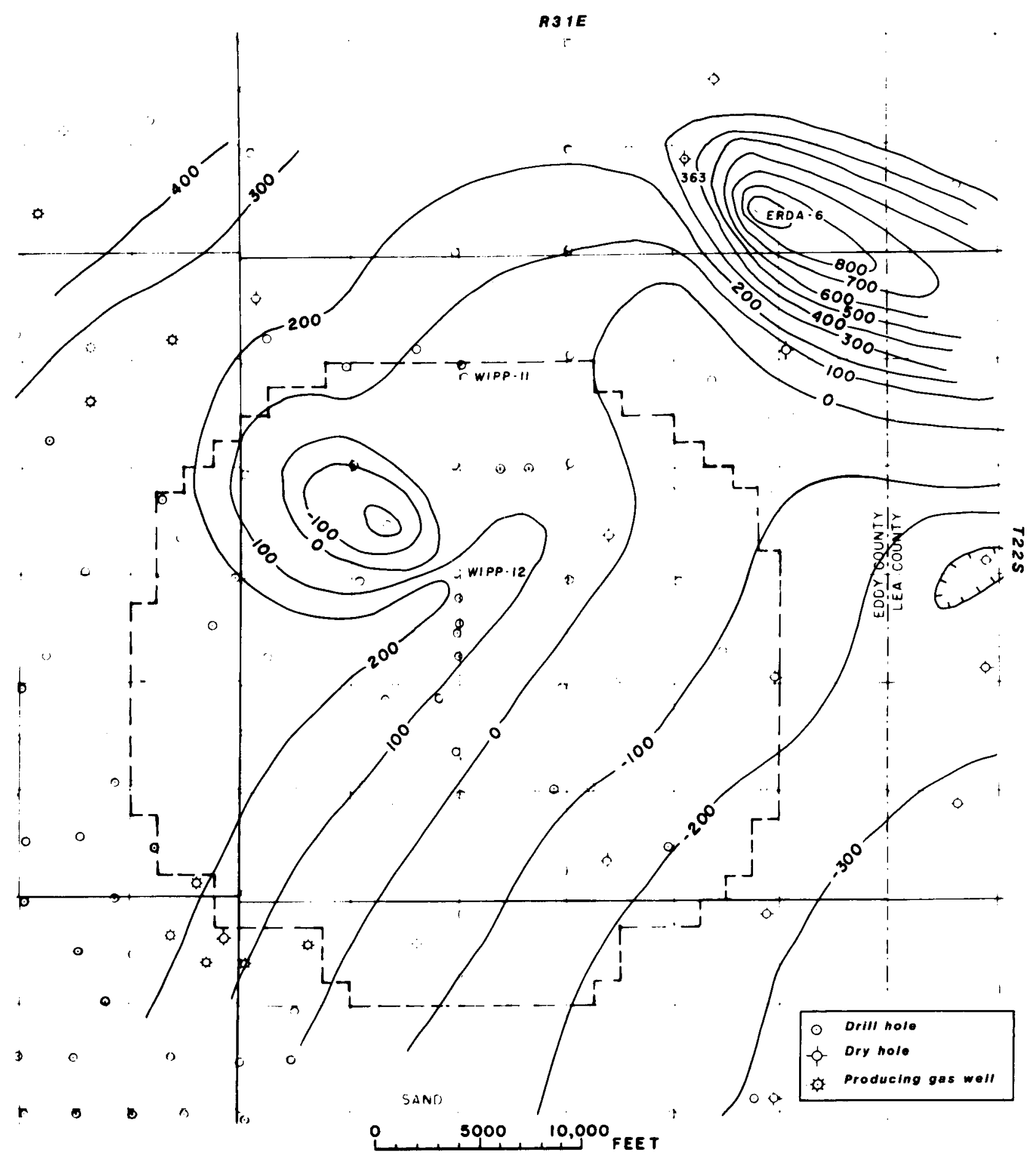

(contour Interval, 100rt; hechures indicate closed low)

Figure 2-10. Structure Contour Map, Top of Anhydrite Unit AII, Castile Formation 


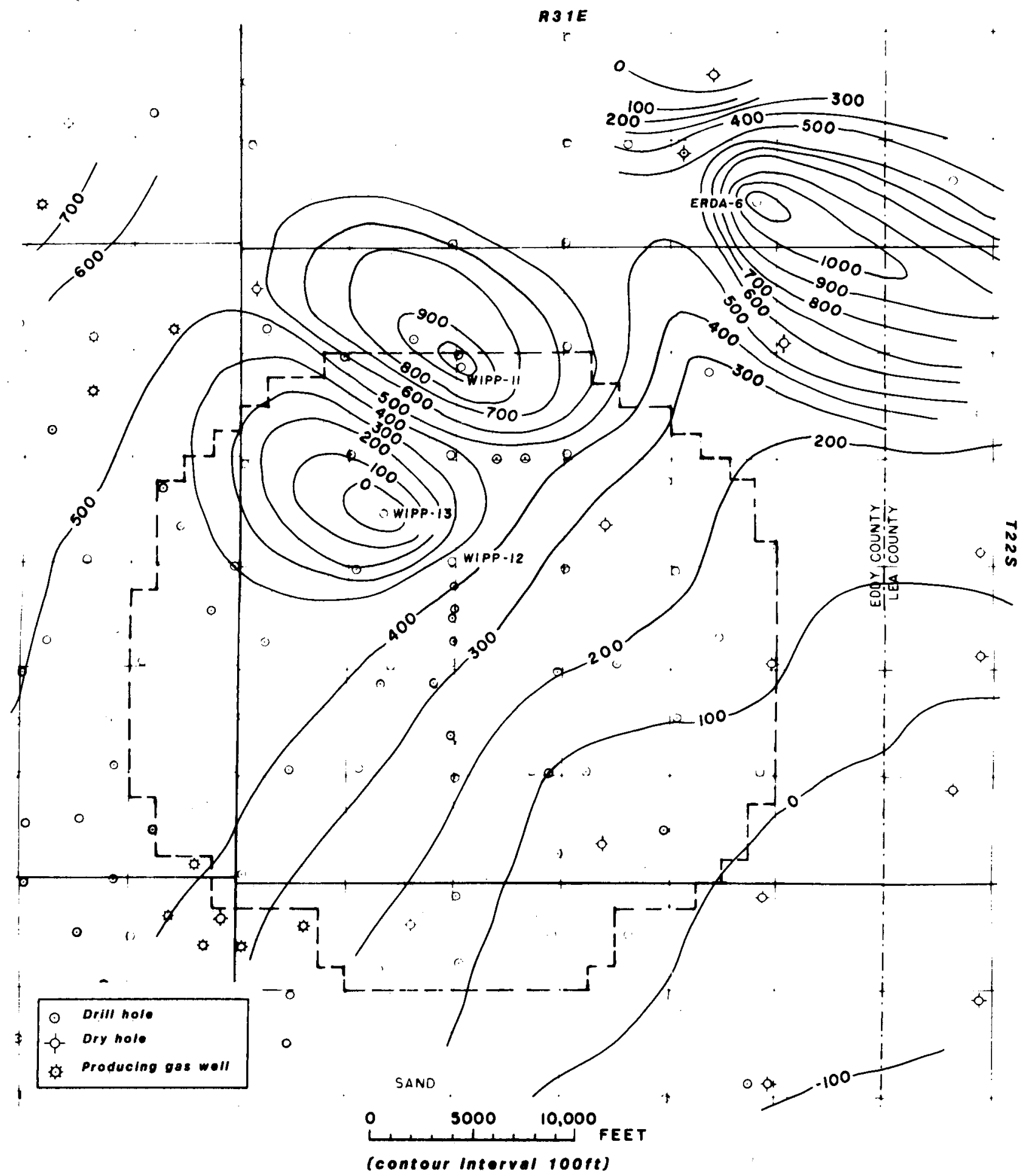

Figure 2-11. Structure Contour Map, Top of Halite Unit HII, Castile Formation 


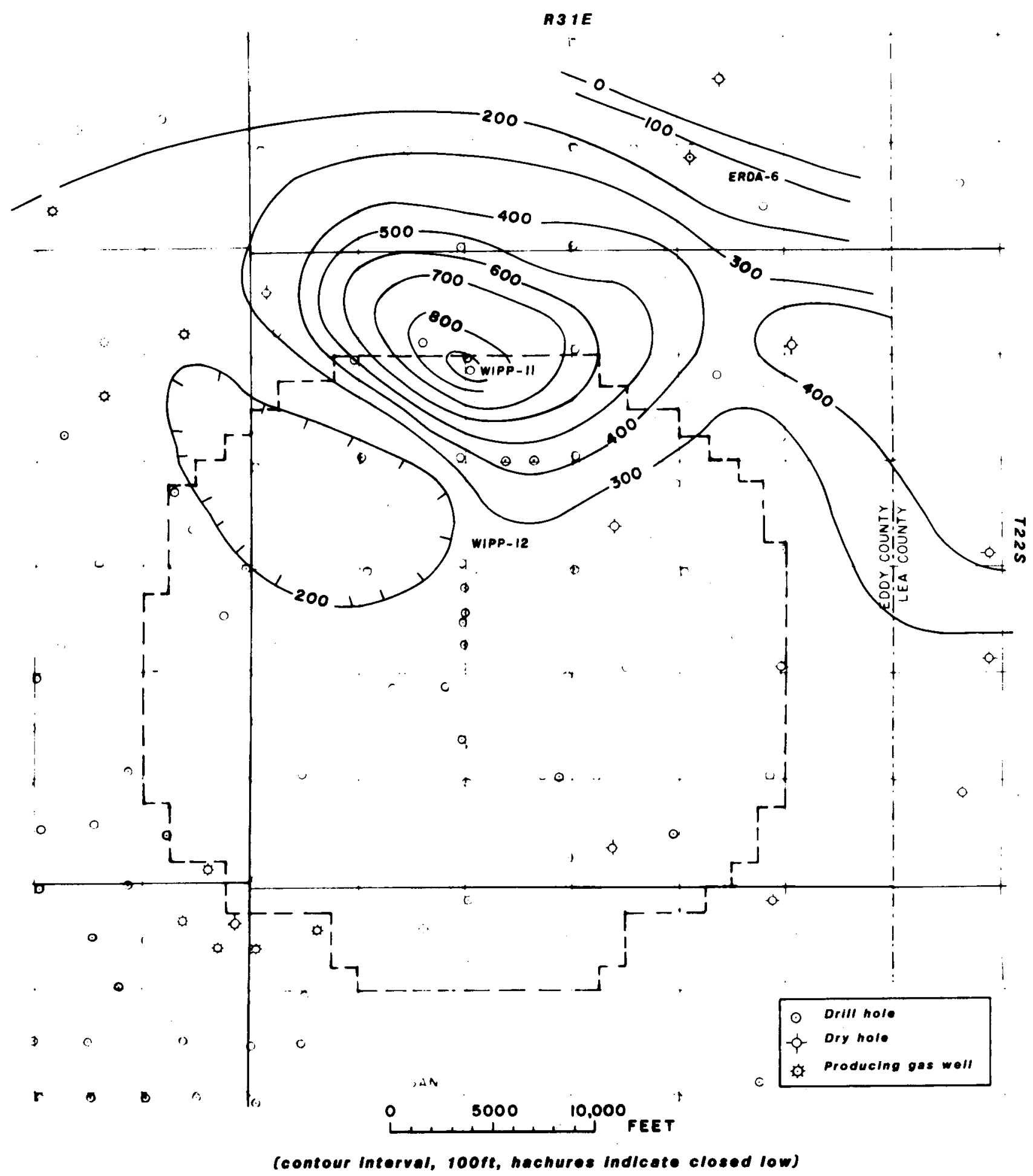

Figure 2-12. Isopach Map, Halite Unit HII, Castile Formation 


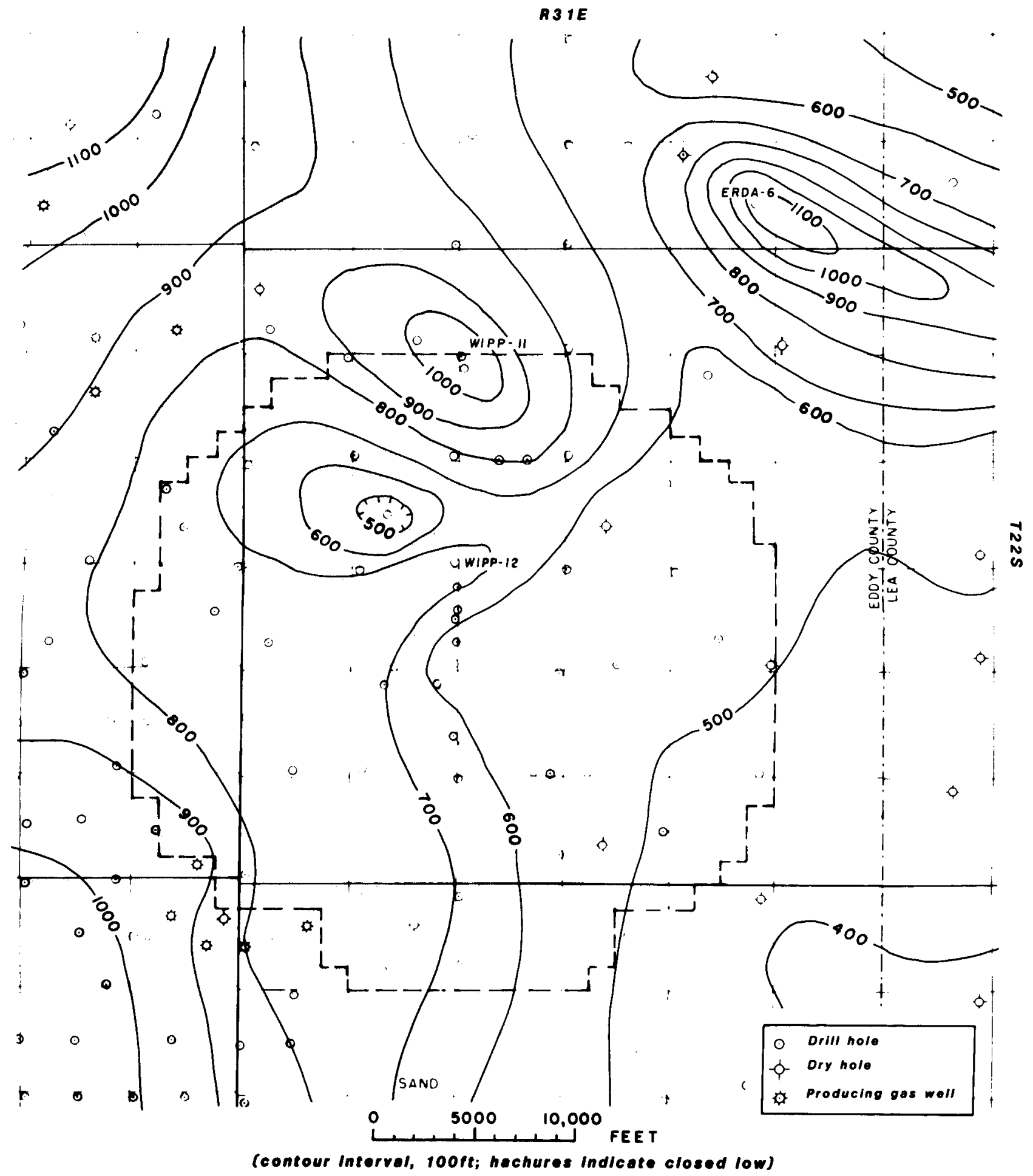

Figure 2-13. Structure Contour Map, Anhydrite Unit AIII, Top of Castile Formation 


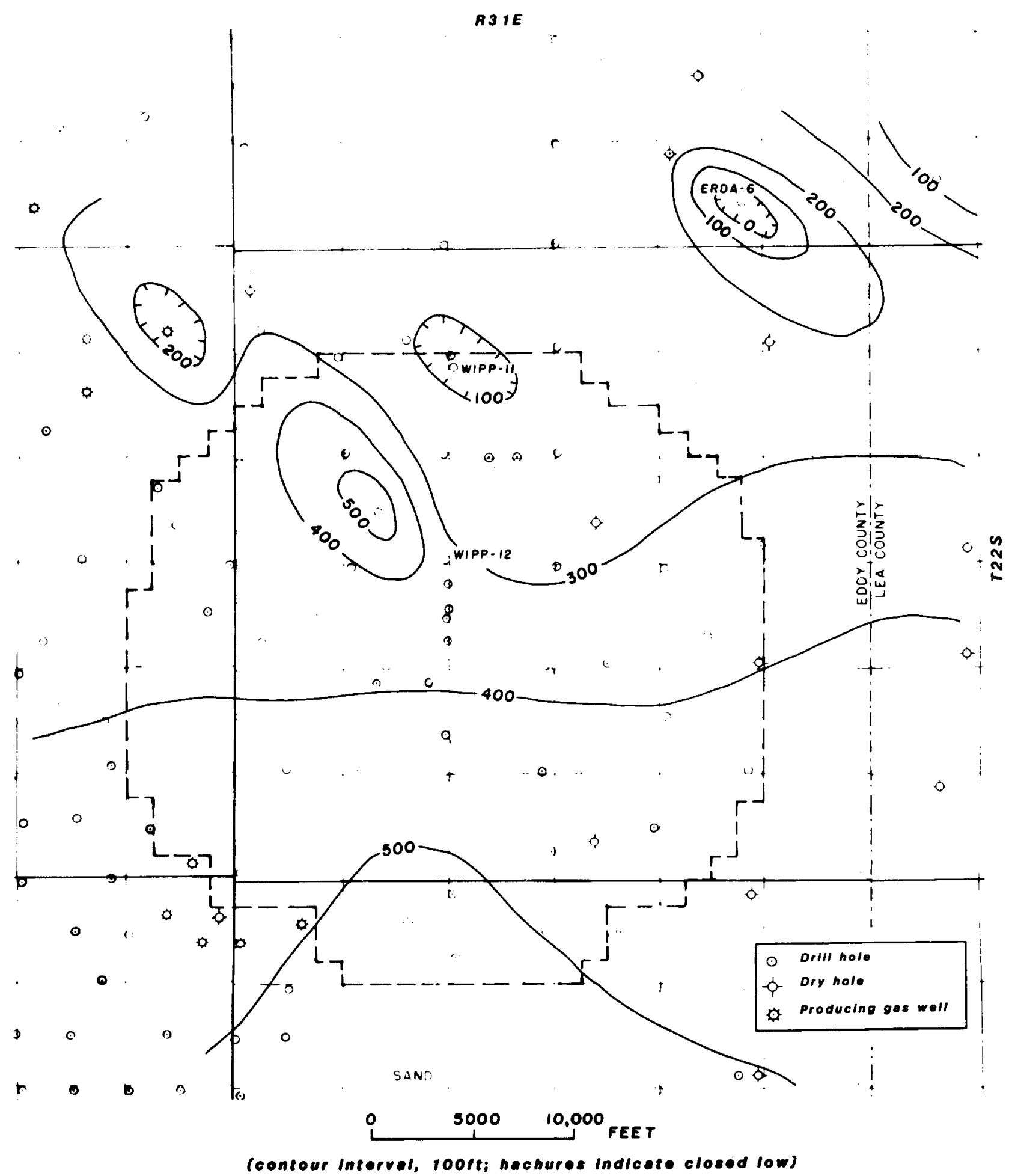

Figure 2-14. Isopach Map, Anhydrite Unit AIII, Castile Formation 


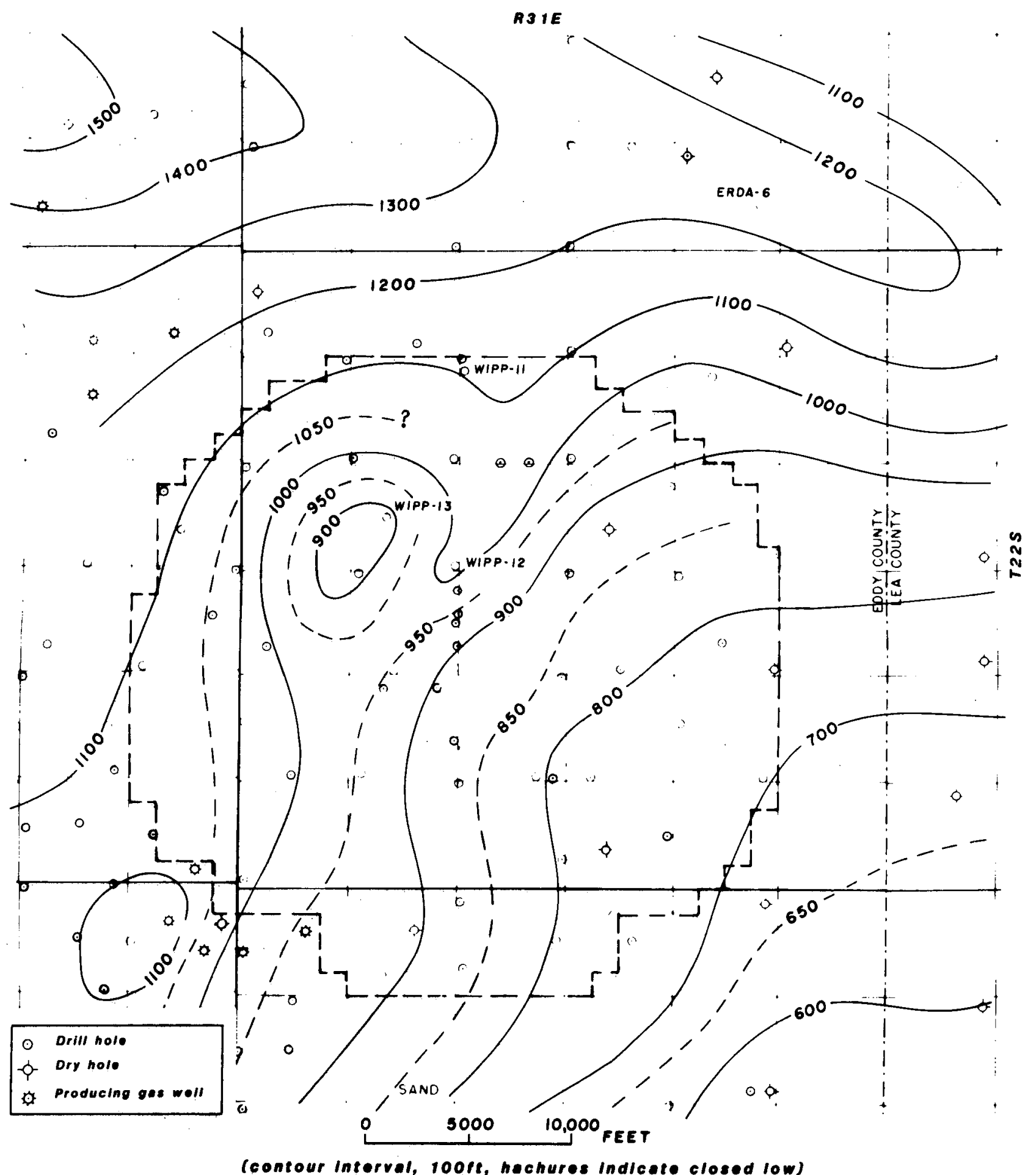

Figure 2-15. Structure Contour Map, Base of Cowden Anhydrite Member, Salado Formation 


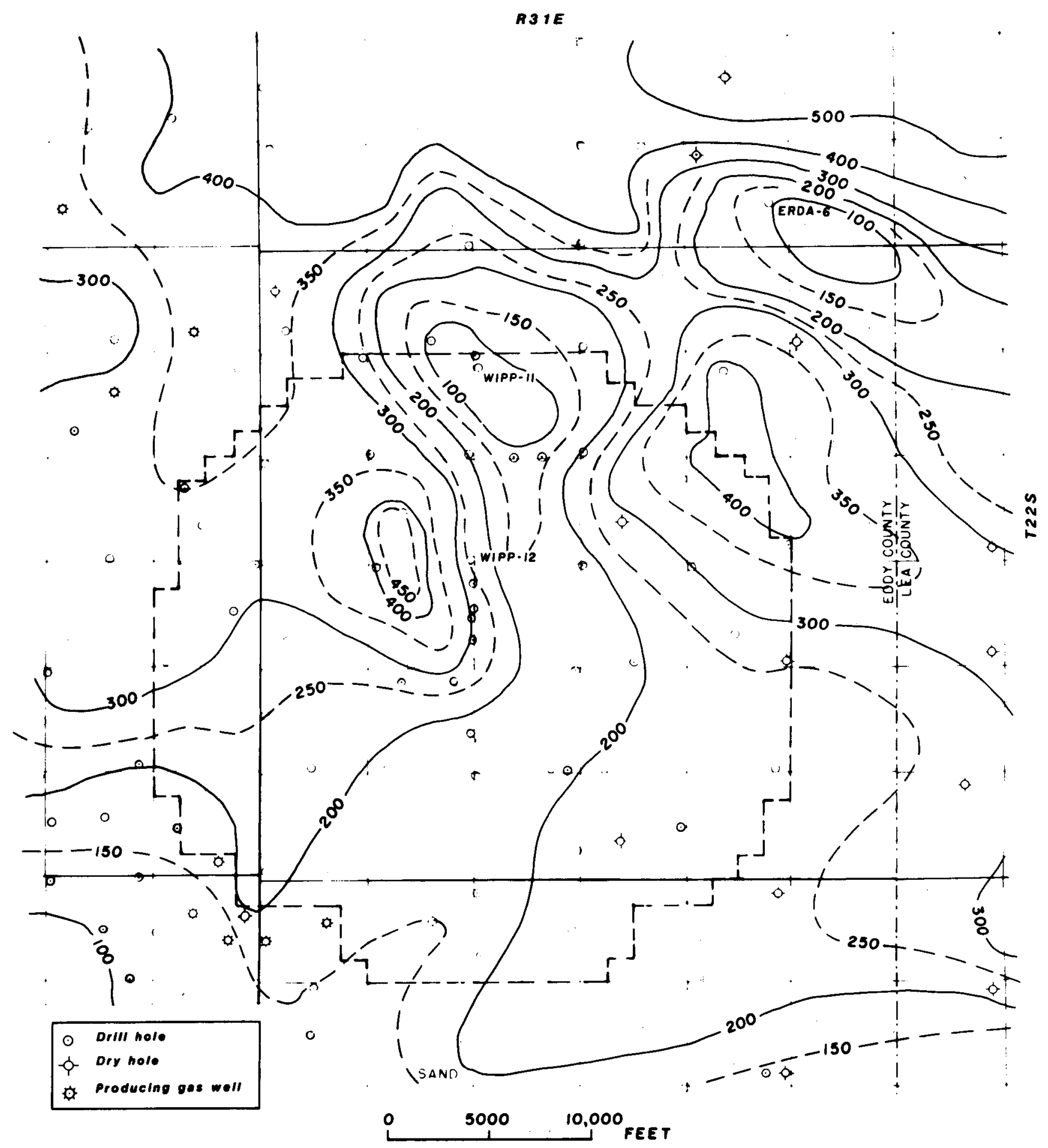

(contour Interval looft)

Figure 2-16. Isopach Map, Base of Cowden Anhydrite Member to Top of Castile Formation 


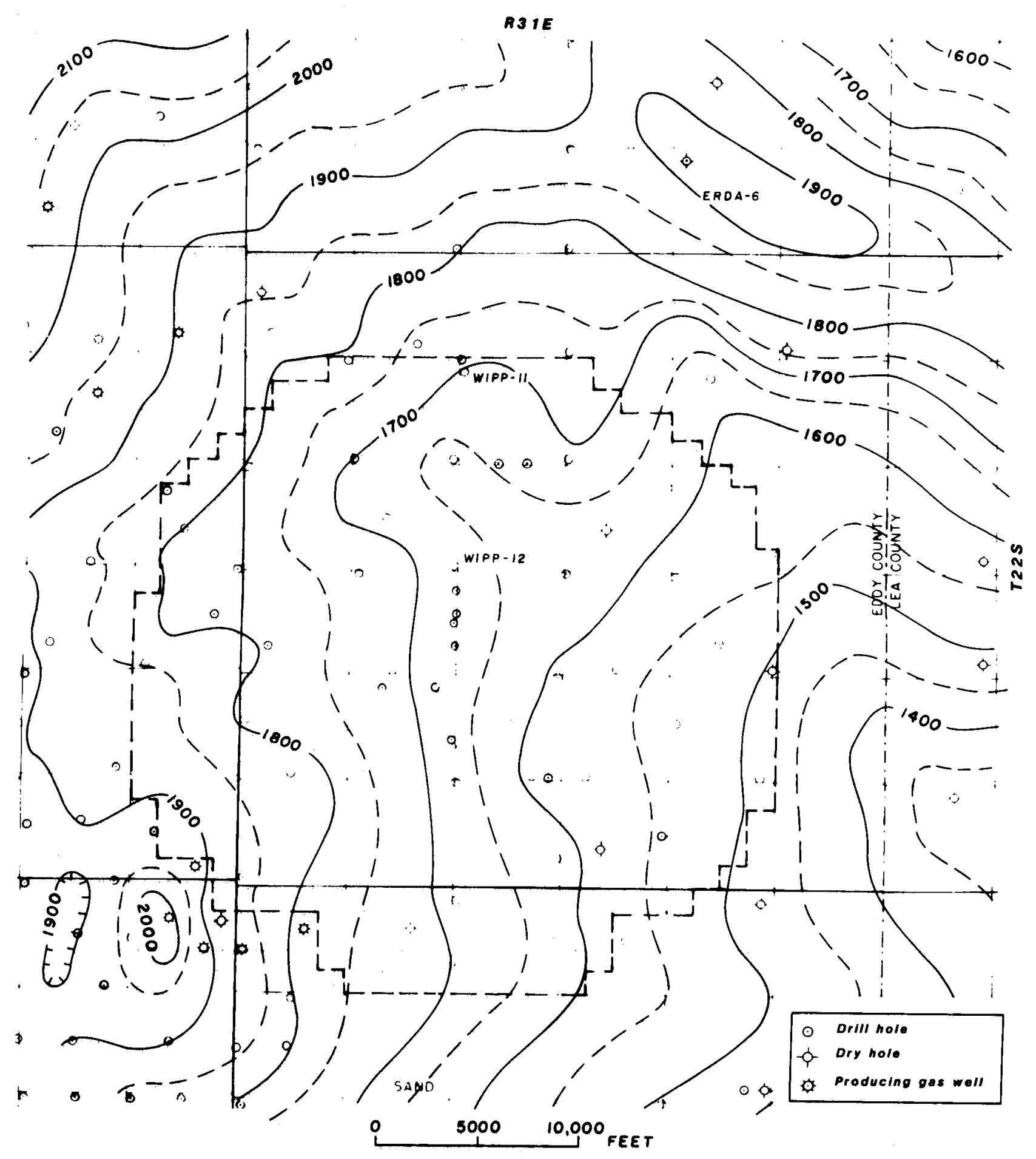

(contour Interval, 100ft; hachures indlcate closed low)

Figure 2-17. Structure Contour Map, Top of Lower Unnamed Unit, Salado Formation 
The isopach of the lower unnamed member (Figure 2-18) makes it appear as if depositional filling of existing structural lows and depositional thinning over existing structural highs of the Castile (Figure 2-13) was responsible for the thickness changes in the lower member. Structure on the McNutt potash-zone surface (Figure 2-19) reflects only in a vague manner the underlying surfaces (note the decrease in contour interval needed because of decreased vertical structure despite the increased number of control points). The structures at WIPP-11 and -13 have disappeared, the plunging nose at ERDA- 6 is present but muted, and a minor high is present off the southwest corner of the site. The isopach map (Figure 2-20) shows a range of $100 \mathrm{ft}$ of thickness over the WIPP site.

The structure of the top of the Salado Formation (Figure 2-21) looks much like that on the top of the McNutt. A broad southeast-dipping synclinal structure trends across the eastern half of the WIPP site. This structure begins to appear on the lower member of the Salado and becomes more pronounced upward. Neither the isopach map of the upper member of the Salado (Figure 2-22) nor the isopach maps lower in the Salado show a thickening of the formation over this synclinal feature. The rapid thinning of the upper Salado northwest of the WIPP site is caused by dissolution of halite at the upper contact of the formation. The line showing the easternmost extent of this dissolution is shown on Figure 2-22.

The numerous marker beds of anhydrite or polyhalite in the Salado Formation can be used for an interesting comparison. Thicknesses of halite between the marker beds between drill holes in the WIPP area show some apparent patterns for 20 of the drill holes, as shown on Figure 2-23. Most of the 20 drill holes have one to three intervals that are thinner or thicker than normal. This is understandable in terms of deposition of halite. Two drill holes, WIPP-11 and B-10JR, are anomalous in that WIPP-11 has thinner halite for 18 intervals, nearly all of which are in the lower unnamed member, and B-10JR has thicker than normal halite intervals in seven of the same intervals. In drill hole C-7JR, about $1 \mathrm{mi}$ east of B-10JR, five of the seven thickest intervals are in the lower Salado. The excess thickness of lower Salado units in the two JR holes may indicate that some causal relationship exists.

Because it is improbable that the thin marker beds in WIPP-11 were deposited on highly dipping surfaces or shallower underwater surfaces, only two reasons can be postulated for the abnormal thickening and thinning. In the case of WIPP-11, where there is a structural high on the Castile, the basin surface could have been slowly rising during early Salado time, or because of the suggested post-Triassic, pre-Pliocene deformation, halite could have been squeezed out of the halite intervals, leaving a thinner than normal section. Either case would explain the abnormal thinning. In the B-10JR area, the thicker lower Salado beds may have been deposited in a slowly downdropping surface. The area at C-7JR may have been affected the same way slightly later in lower Salado time.

The Castile structural high at the ERDA-6 area does not appear to have affected the lower Salado by thinning the halites. The "Infra-Cowden" is thinner than normal here, but only because the diapiric structure of the Castile actually moved upward into the Salado, forcing some "Infra-Cowden" halite aside. The arching of the formations overlying the Castile with no thinning of those formations indicates that at least some of the upward movement of the Castile halites occurred after deposition of these younger formations.

There is no similar arching over the WIPP-11 area, and either there was no post-lower Salado movement or, if movement occurred, the halites in the lower Salado were squeezed outward and thereby absorbed the vertical movement that was not transmitted upward into younger formations.

Rustler Formation-The surface of the Rustler Formation (Figure 2-24) appears much like that on the Salado. The oblong high at ERDA- 6 is present but not prominent, as is the high off the southwest corner of the WIPP site. The southwest-plunging syncline on the Salado in the eastern half of the site has become a closed low. The southeastern part of the syncline is now higher than the northeastern part. This can be explained by the thicker Rustler in the southeast part of the site. The isopach map (Figure 2-25) of the Rustler shows the greater thickness in the southeast. Dissolution of the halite beds in the Rustler is progressing from west to east across the site. As the halite is removed, the formation loses thickness. On the western half of the WIPP site, all of the halite has been removed and the anhydrite beds are hydrating to gypsum. This adds thickness to the formation. To complicate the isopach map even further, some of the newly created gypsum is being dissolved. This threestep alteration process causes the "hummocky" appearance in the western part of the site. Figure 2-25 shows the areas of the WIPP site where these dissolution stages occur. The closed contour at ERDA- 6 is also a reflection of dissolution of halite rather than deposition thinning over a preexisting high. 


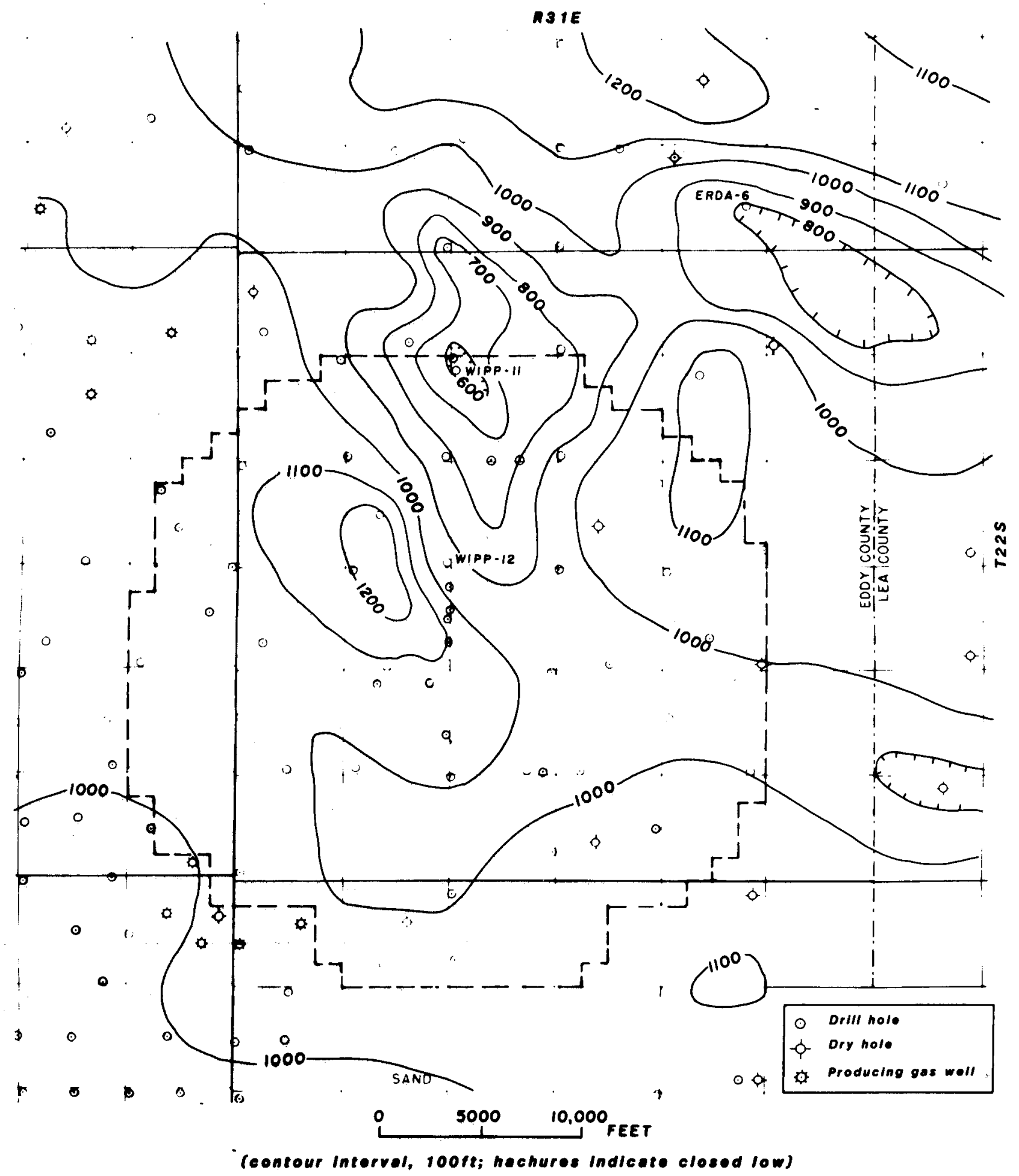

Figure 2-18. Isopach Map, Lower Unit, Salado Formation 


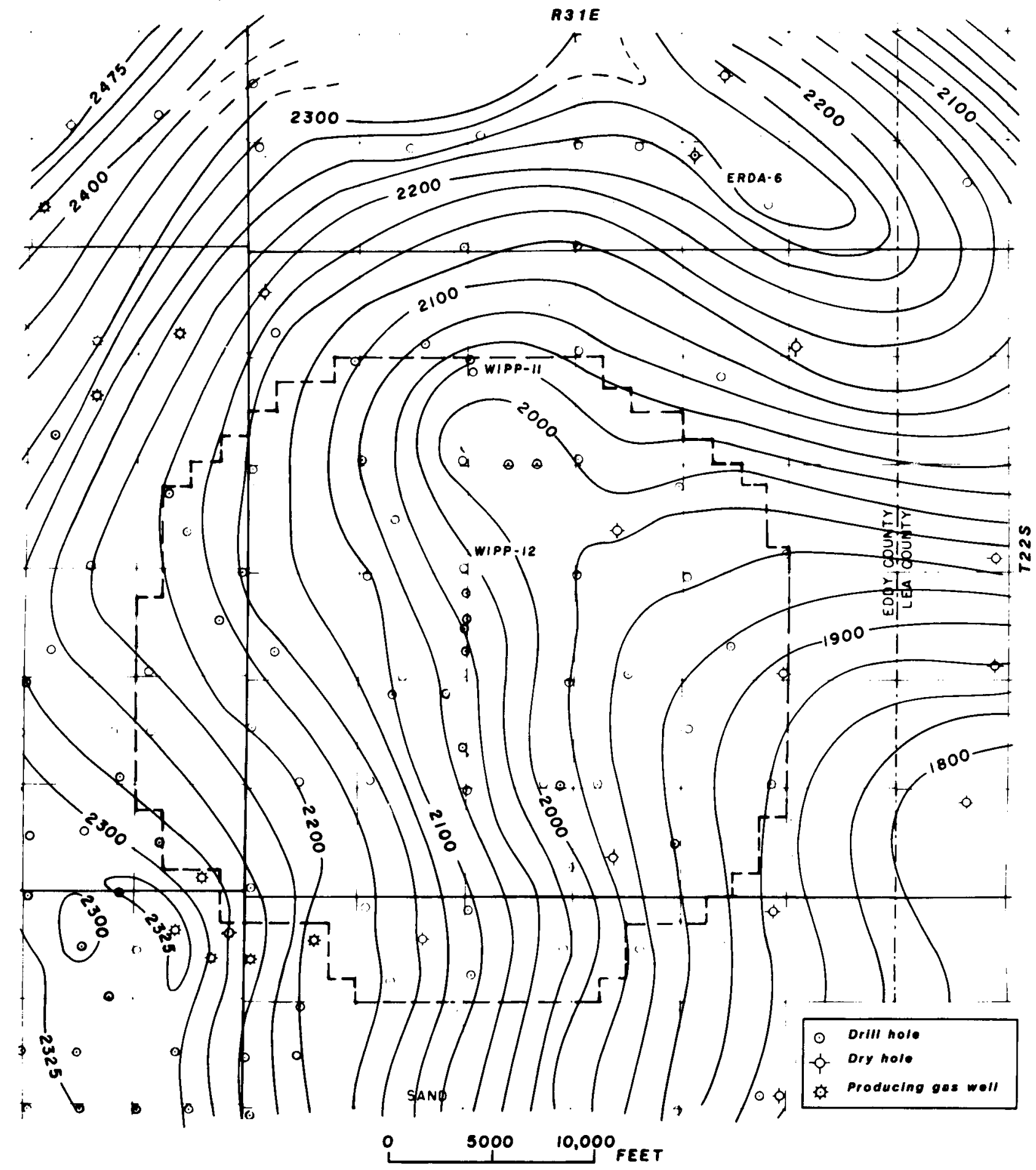

(contour Intervel, 25 ft; hechures Indlcate closed low)

Figure 2-19. Structure Contour Map, Top of McNutt Potash Zone, Salado Formation 


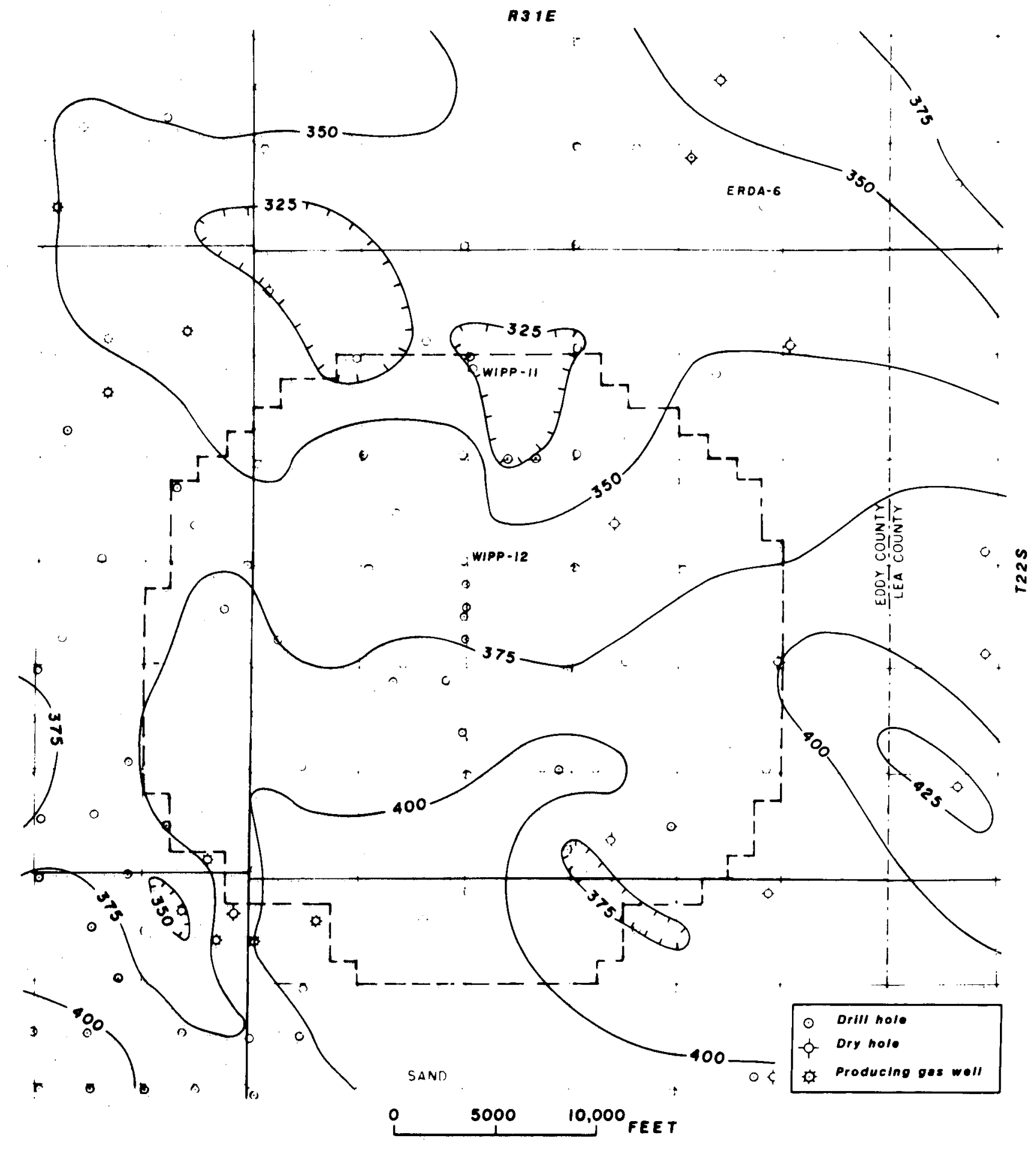

(consour Intervel, $26 \mathrm{ft}$; hechures Indlcete closed low)

Figure 2-20. Isopach Map, McNutt Potash Zone, Salado Formation 


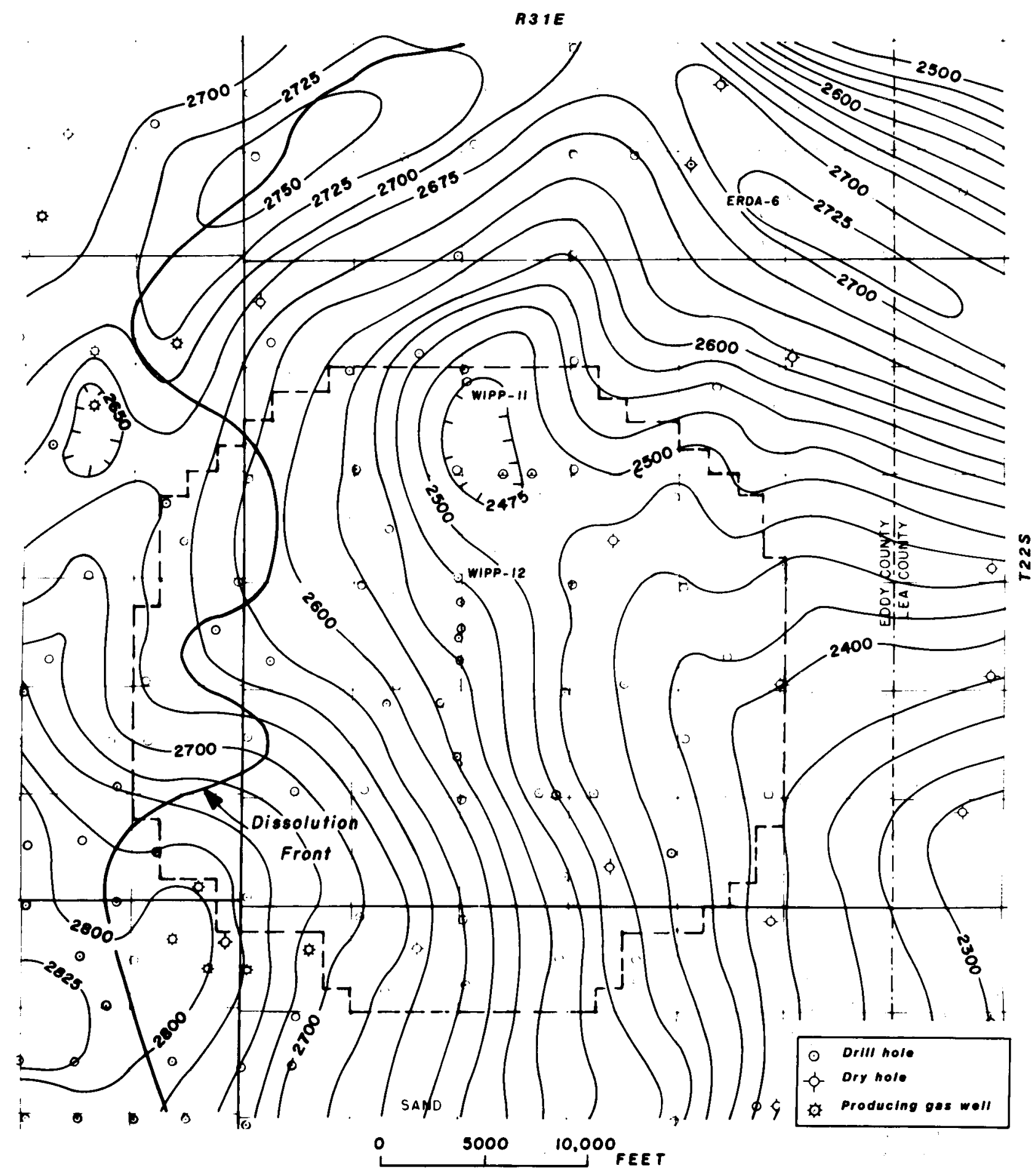

(contour Interval,25ft; hachures Indlcate closed low)

Figure 2-21. Structure Contour Map, Top of Salado Formation 


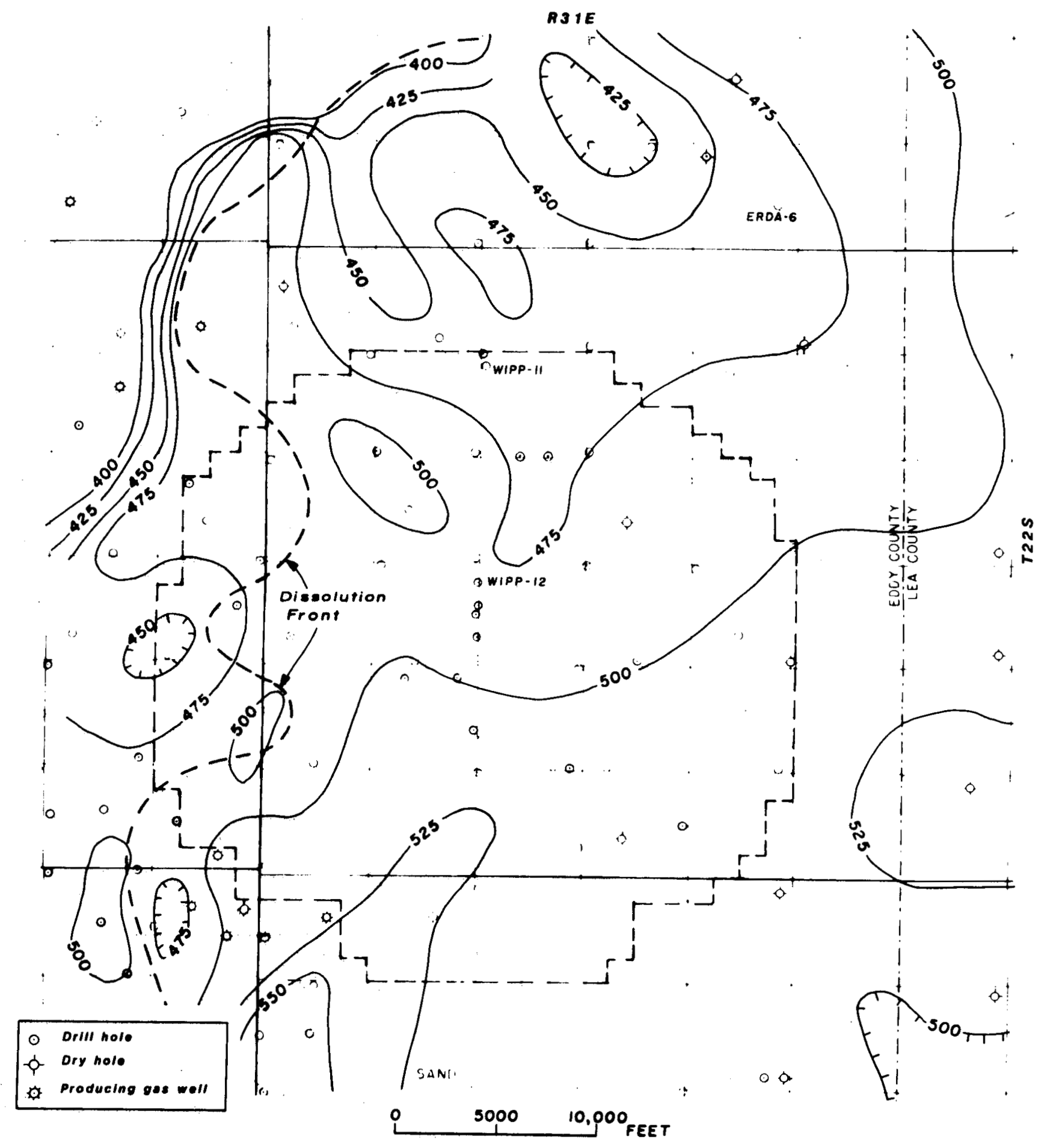

(contour intervat, 25 tt; hechures indlecte closed $10 \mathrm{w}$ )

Figure 2-22. Isopach Map, Upper Unit, Salado Formation 


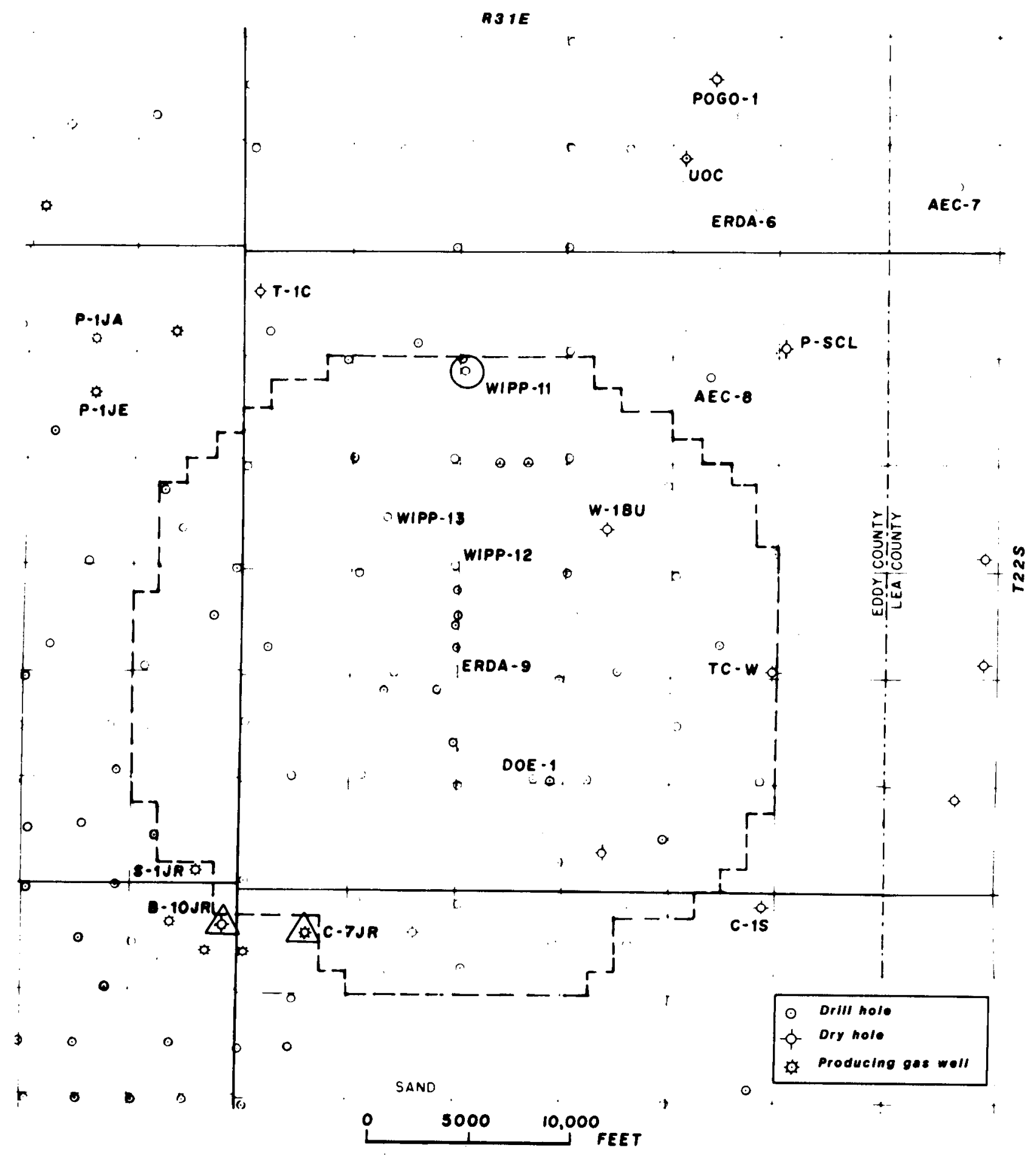

Figure 2-23. Location Map of 20 Drill Holes Used in Study of Salado Formation Marker Bed Intervals (O- Wipp-11 with 18 thinner than normal intervals, $\triangle-B-10 \mathrm{JR}$ and C-7JR with 7 thicker than normal intervals) 


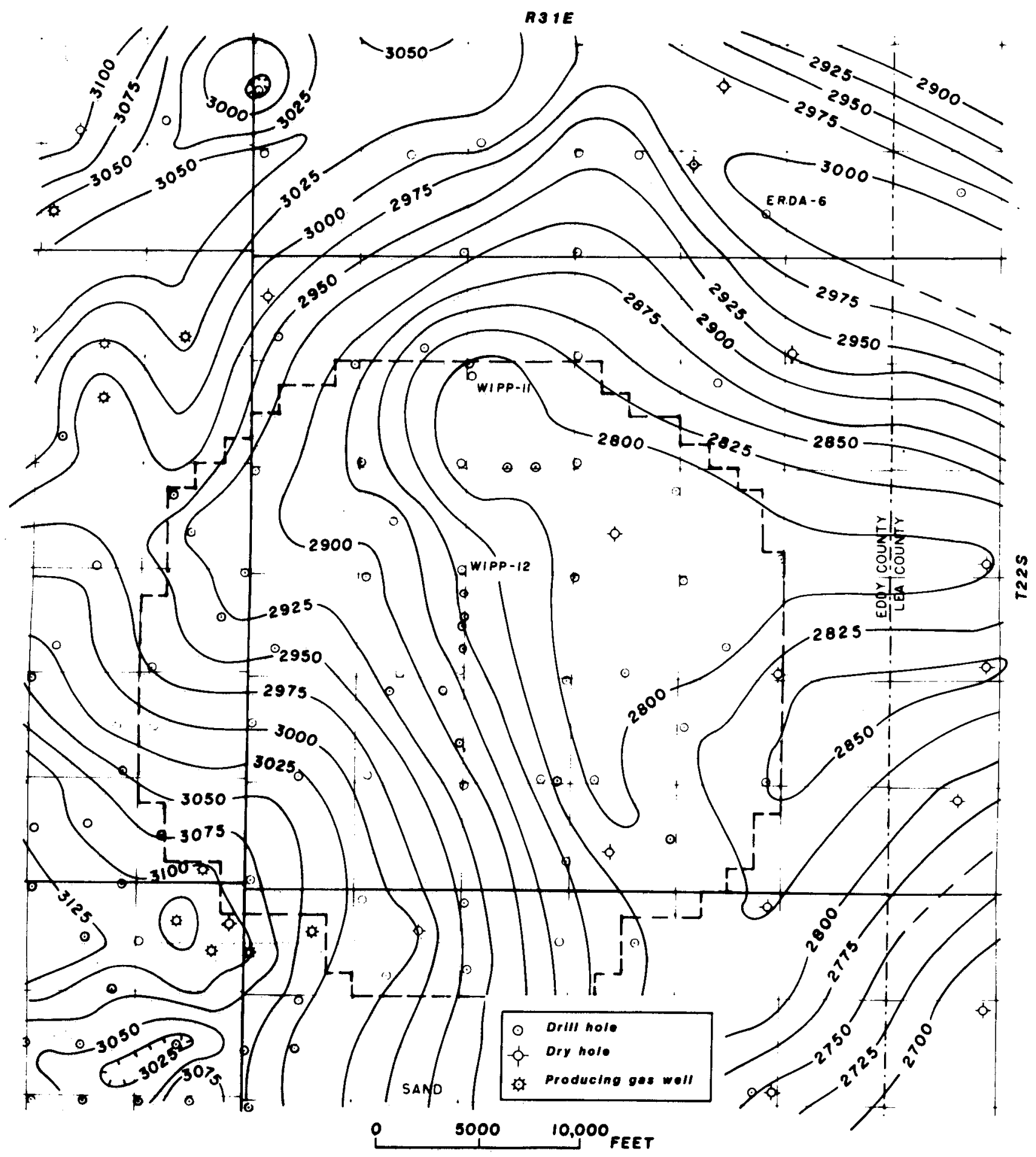

(oontour Intervel, 28 ft; hechures Indlcete closed low)

Figure 2-24. Structure Contour Map, Top of Rustler Formation 


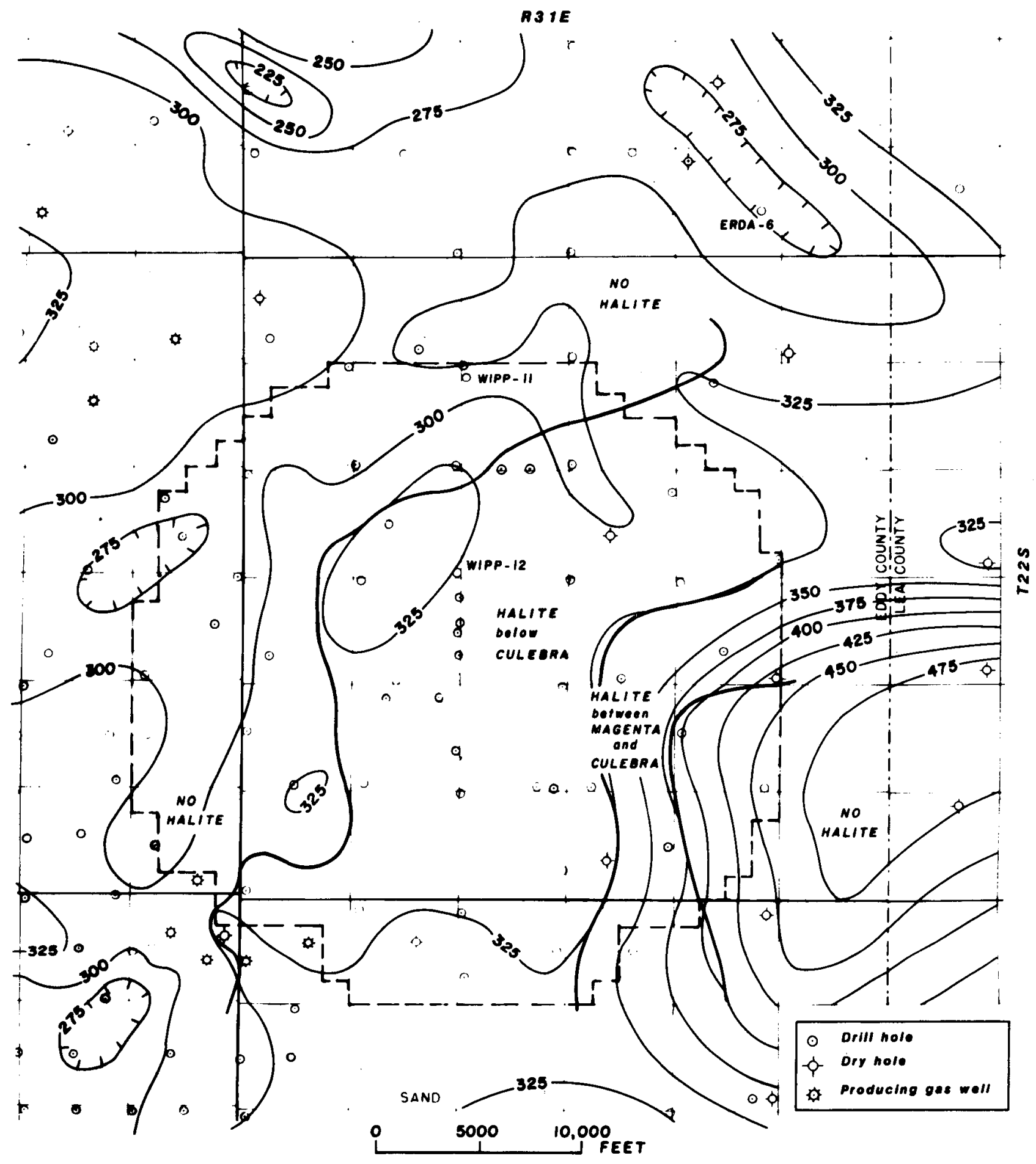

(coneour incerval, $26 f$; hechures indlcate closed low)

Figure 2-25. Isopach Map, Rustler Formation 
Dewey Lake Rod Bods-The Dewey Lake Red Beds are the oldest unit where the structure (Figure 2-26) and thickness (Figure 2-27) are more a reflection of surficial erosion than of underlying structure. Figure 2-27 shows the influence of surficial erosion on the western half of the WIPP site where the overlying Santa Rosa Sandstone has been stripped off, thus allowing erosion to occur. On the eastern half of the site, the surface of the Dewey Lake reflects some of the structure of the underlying Rustler Formation.

\subsubsection{Tertiary}

Santa Rosa Sandstone-The structure map on the Santa Rosa Sandstone (Figure 2-28) shows little in the way of underlying structure. The formation has been eroded from the western half of the site. The thickness map of the unit (Figure 2-29) indicates that the underlying synclinal feature in the eastern part of the site may have been filled in by thicker deposits of Santa Rosa material. The southwest-plunging trough in the southeast corner of the WIPP site may reflect a drainage channel that developed on the Santa Rosa during or after deposition.

\subsubsection{Quaternary}

Gatuñ Formation-Outcrops and deposits of the Gatuña Formation are sparse in the WIPP site area. A structure map shows very little that can be used in the interpretation, and no map is included here. The isopach map (Figure 2-30) is included here only to show the sporadic depositional pattern of the formation. The map shows in a general way that the formation was deposited in topographic lows on the Santa Rosa and Dewey Lake. Erosion of the Santa Rosa had progressed to the point that it had been removed from half of the WIPP site prior to Gatuna time.

\subsection{Discussion and Conclusions}

Definition of the structure of the rocks under the WIPP site is the main purpose of this chapter. This definition includes both the actual configuration of various units and, if possible, a reasonable time frame during which deformation of some of the units took place.

The major structural deformation, as presently mapped, occurs in the Castile Formation. The two cross sections (Figures 2-5 and 2-6) illustrate the differences in thickness and elevation of the various mappable units of the Castile. The structure and isopach maps of these units show the same features from a plan view.

It is apparent that the major cause of the structures under and around the northern part of the WIPP site has been the flowage of the two halite units (HI and HII) of the Castile. Movement on the interpreted faults cutting the lowest anhydrite (AI) may have been the triggering mechanism for this flowage. Another possible triggering mechanism may have been the eastward tilting of the Delaware Basin during mid- to late-Cenozoic time (Powers et al, 1978). Overburden, possibly including Cretaceous rocks not now present, may have helped in the Castile halite movement by adding sufficient weight in places over the halite to initiate movement (Jones, 1973). Jones (1973) has bracketed the age of Castile deformation to a period from post-late Triassic to late Cenozoic (prePliocene). There seems to be general agreement that movement of the halites of the Castile occurred sometime between the time after deposition (late Permian) of the Castile and before the time of deposition of the Pliocene Ogallala Formation.

Study of drill and geophysical logs shows that in the lower Salado, below the Cowden Anhydrite, there is a general thickening of the section in areas where the underlying Castile is structurally lower than normal. The geophysical logs also indicate numerous thin beds of anhydrite below the Cowden Anhydrite in these areas. It appears as if the structures were forming as the lower Salado was being deposited, and in minibasins over the Castile structural lows, some anhydrite was being deposited along with thicker halite beds. The cross section (Figure 2-4) shows these deposits as "transition zones" at three drill holes, B-JR10, WIPP-13, and POGO-1. WIPP-13 has core in this "transition zone," for the other two density logs were used to identify lithology. This lower part of the lower member of the Salado, called the "InfraCowden," is one of the most difficult lithologic units to interpret. Southward from the WIPP site the Cowden Anhydrite appears to cut across the lower Salado and merge with the uppermost Castile anhydrites (Jones, $1973, p$ 15). This relationship is shown on Figure 2-5 on the south side of the cross section at the Sandy Unit No. 1 drill hole. Across the WIPP site the InfraCowden thickens and thins as the underlying Castile surface lowers and rises. This change in thickness of the Infra-Cowden gives the appearance of a unit that was deposited on an uneven surface of the Castile. 


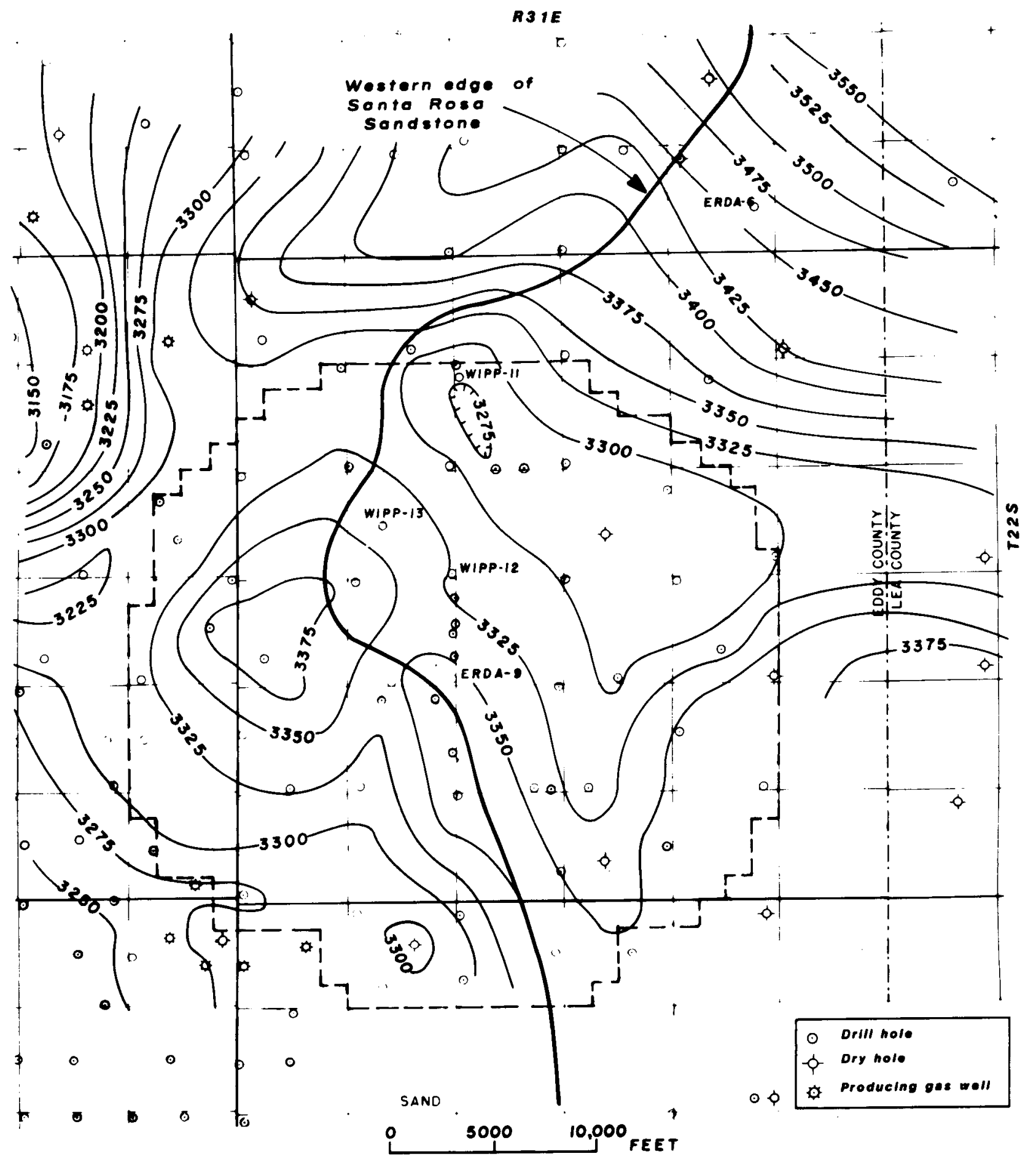

(contour interval, $25 \mathrm{ft}$; hechures indleate closed low)

Figure 2-26. Structure Contour Map, Top of Dewey Lake Red Beds 


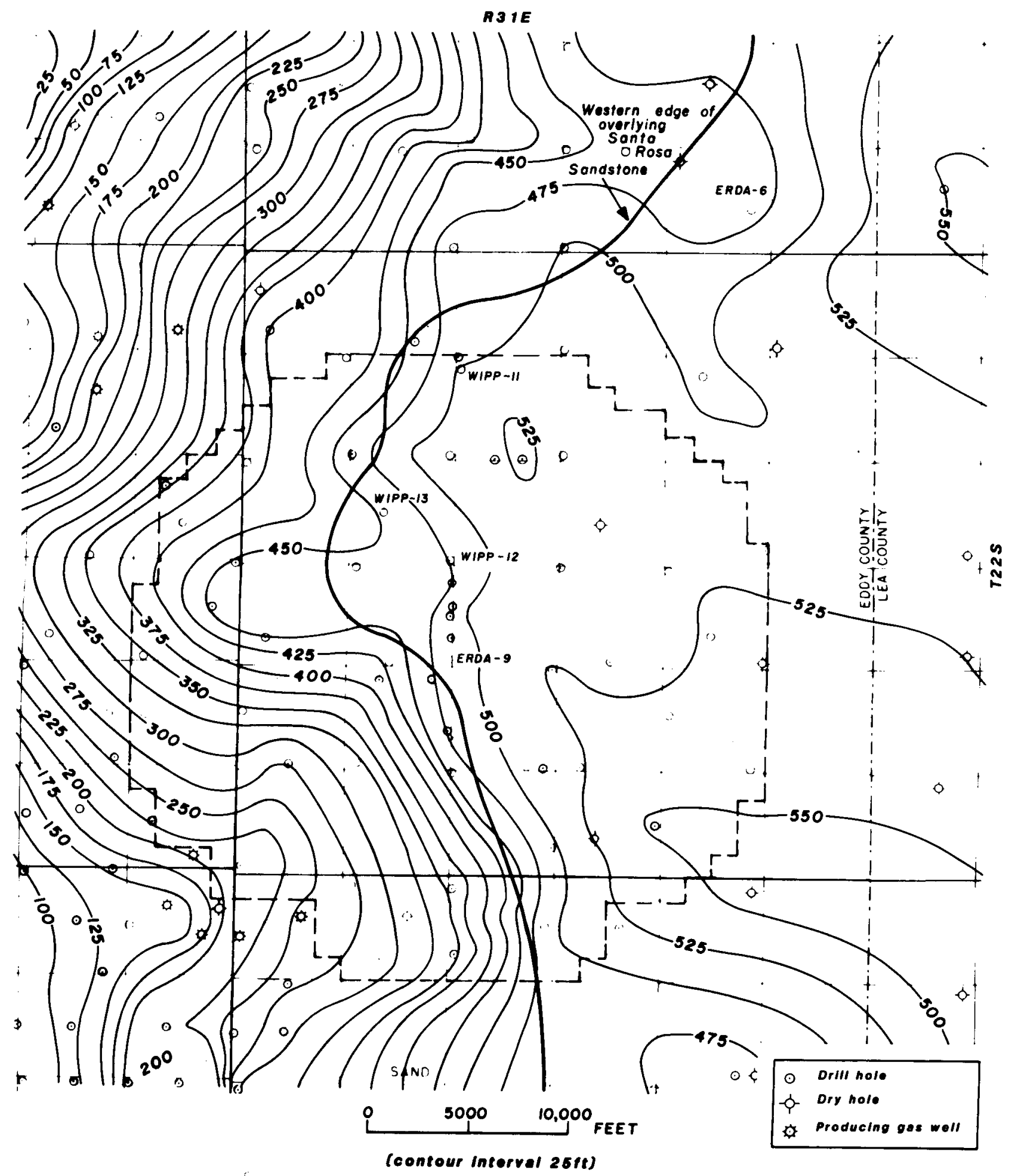

Figure 2-27. Isopach Map, Dewey Lake Red Beds 


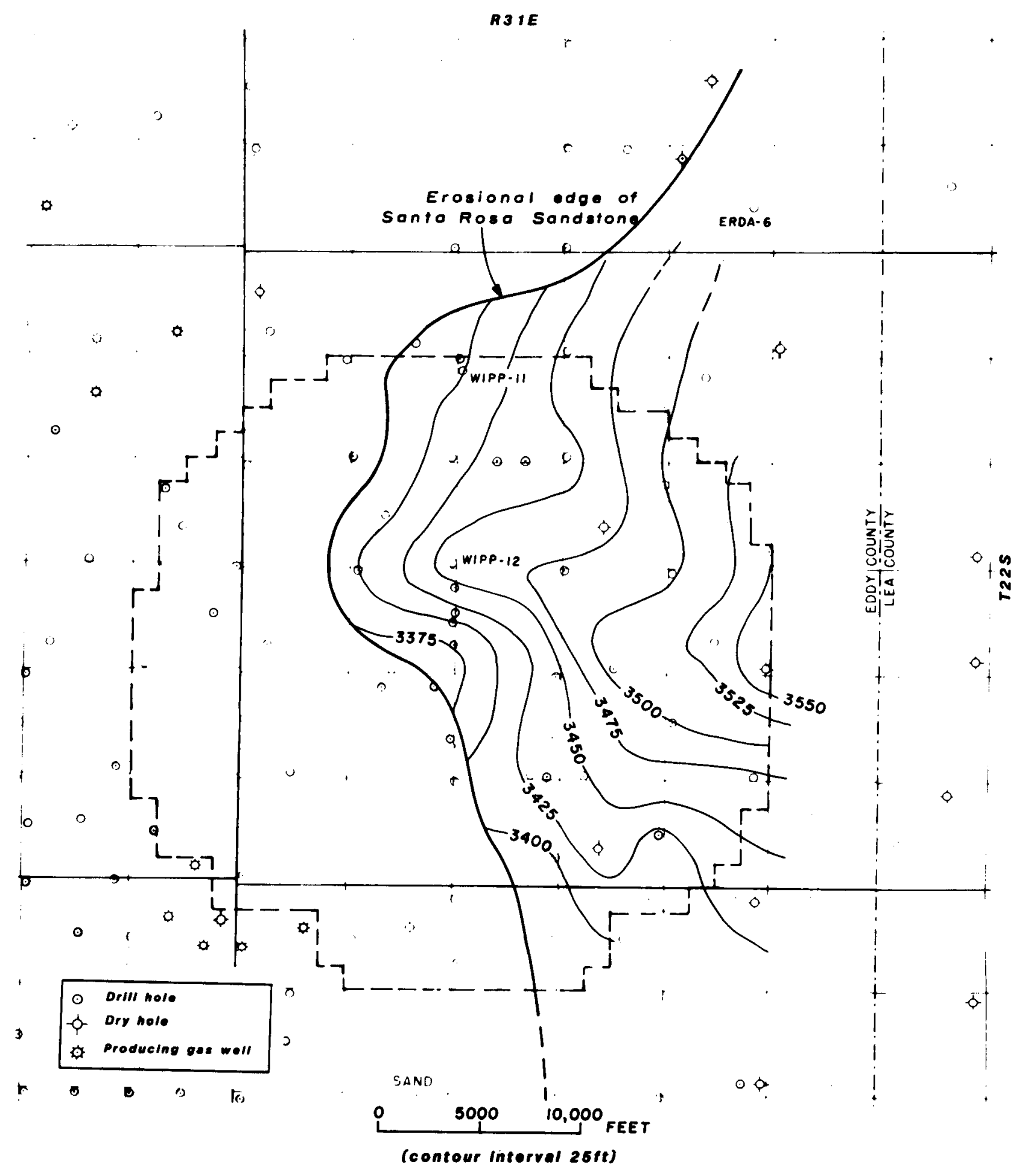

Figure 2-28. Structure Contour Map, Top of Santa Rosa Sandstone 


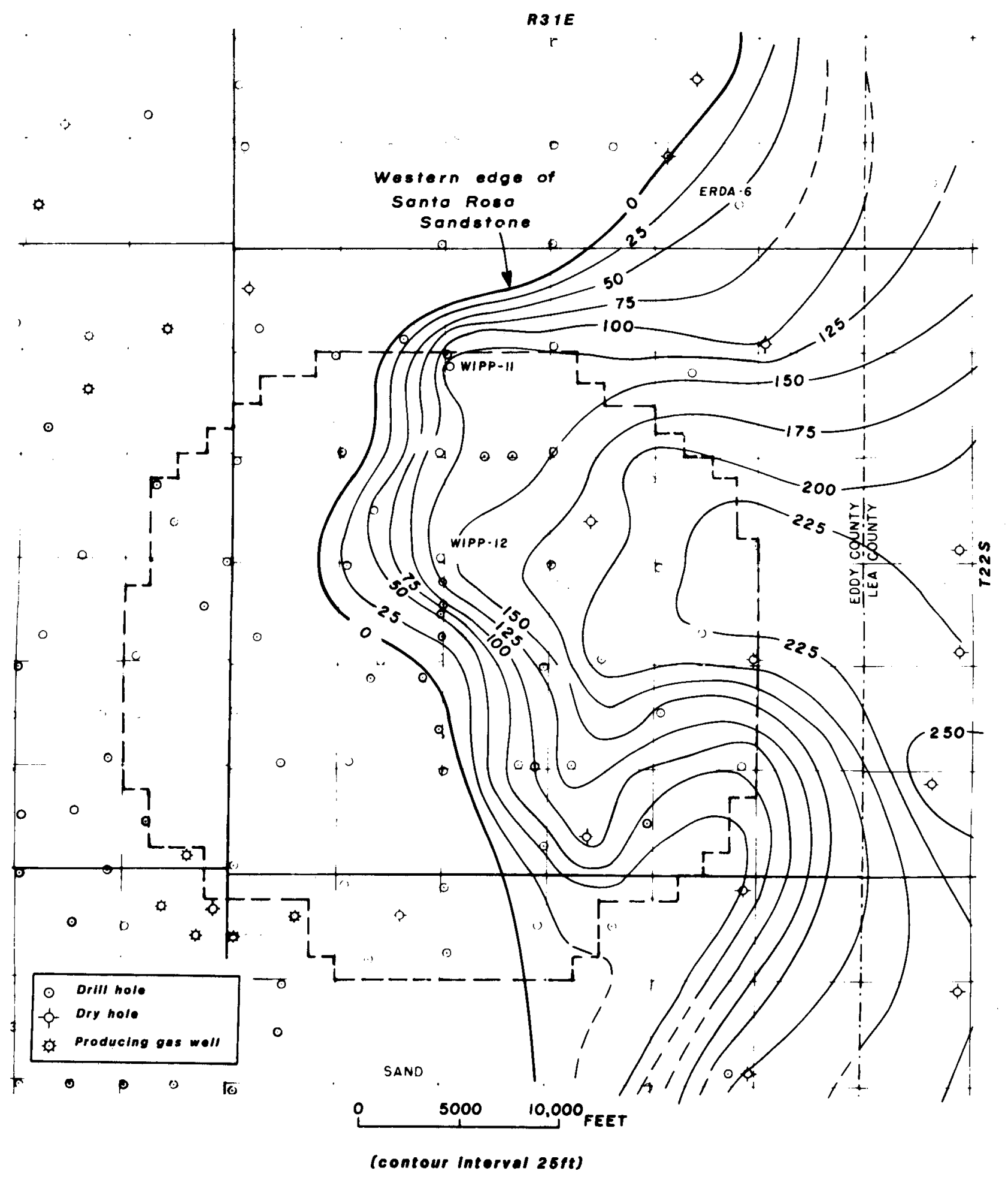

Figure 2-29. Isopach Map, Santa Rosa Sandstone 


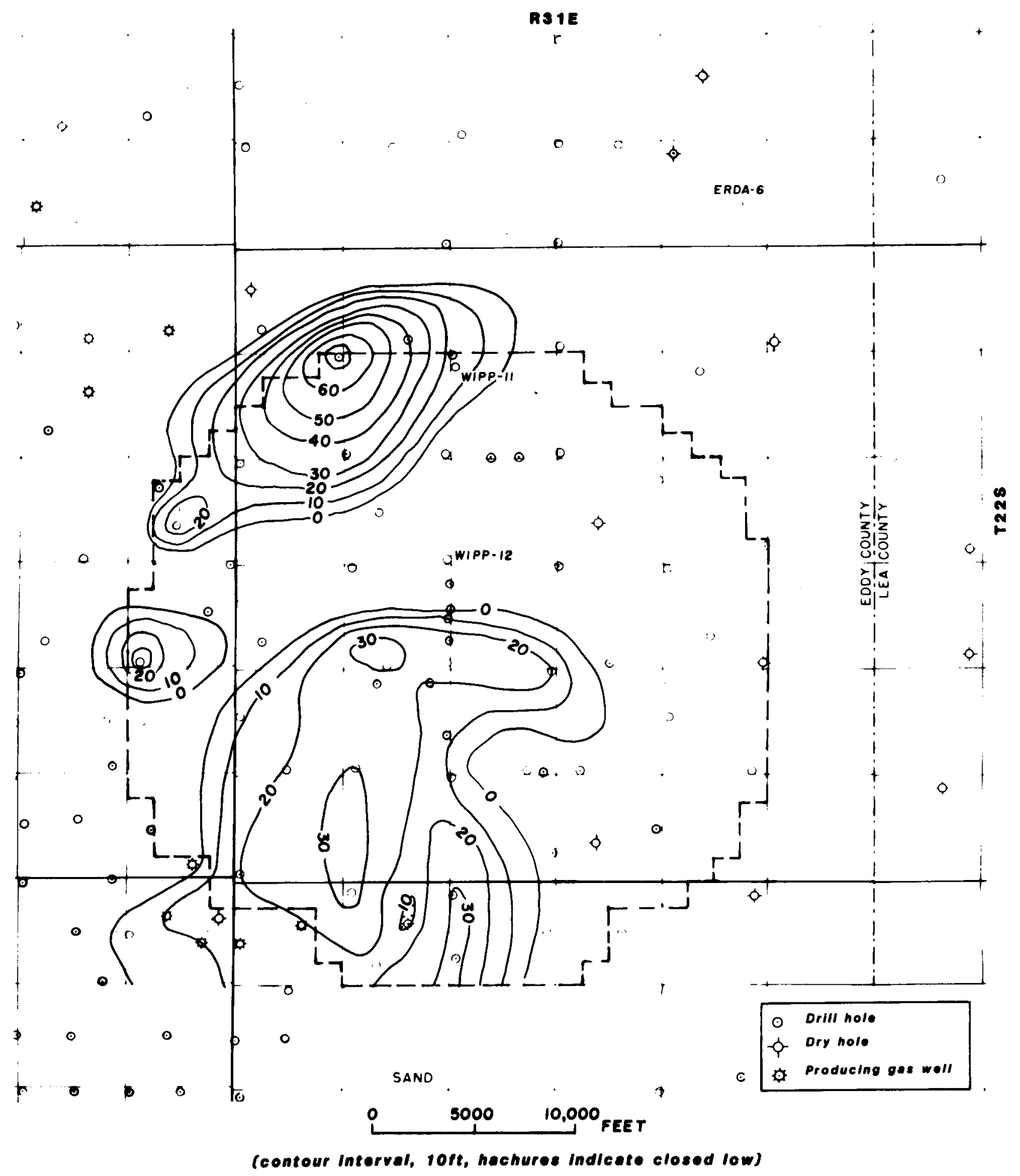

Figure 2-30. Isopach Map, Gatuña Formation 
This interpretation would call for movement of the Castile halites much earlier than has been suggested. The problem of what caused the movement is compounded because there would be almost no overlying sediments that are needed to instigate the initial halite movement (the generally classical cause of salt flowage).

The formations overlying the Castile, specifically the upper two-thirds of the Salado, the Rustler, and the Dewey Lake Red Beds, show no unusual thickening or thinning across the WIPP site. It is true that there are differences in thickness; the Salado thins to the northwest of the site, the Rustler thins from east to west, and the Dewey Lake thins east to west. In the first two cases, dissolution of halite causes the thinning. In the third case, surface erosion is the cause. Nowhere does it appear that these three formations were deposited on existing highs or lows caused by the vertical movements in the Castile. Even at ERDA-6 (Figure 2-4) the above units do not thin, although they are bowed upward. This indicates that at least some of the upward movement of the Castile occurred after deposition of the Dewey Lake Red Beds. Additional evidence presented by Jones (1973) indicates that this upward movement affects rocks as young as Triassic (Chinle Formation), but not the Ogallala of Pliocene age.

At the WIPP-11 site there is no evidence showing that the rocks younger than the Castile were pushed upward by the movement of HII. It is possible that the "Infra-Cowden" halite was squeezed out and away from the area of WIPP-11, but this loss does not account for all the extra thickness of the Castile at that location.

The stretching and consequent thinning of AII in the ERDA- 6 area has been discussed by Anderson and Powers (1978). They (and Jones, 1981) have suggested that the AII unit had been breached by the upwelling HII from below as a diapiric structure. AIII at the WIPP-11 site is thinner than normal and may have been thinned by stretching much like AII at ERDA-6. It is also possible that a topographic high existed at WIPP-11 during deposition of AIII and that the thinness of the unit is caused by original lack of deposition.

On the cross sections (Figures 2-4 and 2-5) AII is shown as a continuous band or layer. It is quite probable that in the areas of extreme structure, such as near ERDA-6 and WIPP-11, the anhydrite consists of larger broken and tilted blocks rather than a continuous layer.
At the WIPP-13 locality AIII is thicker than normal and HI and HII are thinner than normal. The area appears to have subsided prior to or during deposition of AIII. If faulting of the underlying Bell Canyon Formation and AI of the Castile as shown on Figure 2-5 occurred during this time, some of the halite could have been forced northeastward under the WIPP-11 site and AIII would have been deposited in a slowly subsiding local basin.

There is no indication that the Salado and younger beds over the Castile in the WIPP-11 area were forced upward as they are at ERDA-6. This fact again seems to indicate that the movement in the Castile at WIPP-11 occurred very early in Ochoan time, specifically at or near the end of Castile time. The movement of halite at the ERDA- 6 area, in contrast, seems to have occurred over a longer time period starting during late Castile and extending to the pre-Pliocene.

The structure and isopach maps of the upper twothirds of the Salado and younger formations give no real indication of the large amount of movement found in the Castile. Structure maps do show the uplifted area around ERDA-6.

Of more interest in the younger formations is the northwest-trending synclinal feature in the eastern part of the WIPP site. This feature begins to appear on the structure map drawn on the top of the unnamed lower member of the Salado. The structure is more noticeable on the top of the McNutt potash zone and the top of the Salado.

Isopach maps of the McNutt and upper unnamed members of the Salado do not show a thickened section over the syncline. This indicates that subsidence occurred after Salado time.

The structure maps of the top of Rustler and Dewey Lake Red Beds show that the syncline is still present at its northwestern end, but it dies out southeastward and actually becomes a closed depression. This apparent disappearance of the plunging syncline is caused by a thick deposit of the Rustler in the southeast part of the WIPP site. In this part of the site, no halite has been removed from the Rustler. The Rustler structure naturally reflects the thicker section and the Dewey Lake does the same.

The Santa Rosa Sandstone structure map (Figure 2-28) shows no indication of the syncline, but then not much of the eastern part of the WIPP site has been contoured. The isopach map of the Santa Rosa explains the disappearance of the syncline on the Santa Rosa structure. There is a thickening of the Santa Rosa over the synclinal area. The sedimentary rocks of 
the Santa Rosa were deposited in an already subsided or subsiding trough, and by the end of Santa Rosa time the trough had been filled in.

The subsidence of the syncline began sometime after Permian time and ceased prior to the Triassic. The subsidence apparently was rooted in the lower unnamed member of the Salado Formation.

The Gatuña Formation, a flood-plain deposit, was laid down about 500,000 yr ago and covered most of the area on and around the WIPP site. Remnants of the formation are still present, although much of the unit has eroded away. The isopach map (Figure 2-30) shows three prominent deposits on the western half of the WIPP site. The two easternmost deposits appear to have been deposited in erosional lows that straddle an east-west high on the Dewey Lake Red Beds. This high is believed to be the result of the Dewey Lake Red Beds having been protected from erosion until recent time by a cover of Santa Rosa Sandstone.

The caliche and sand-dune cover were studied for evidence of faulting at the surface. Trenches were dug through the caliche, but no displacements were seen. Likewise, arroyo banks were examined for displacements, but none were found.

From the preceding data it is not possible to date the age of Castile halite movement, except to say that it began no earlier than late-Castile time and ceased prior to pre-Pliocene time.

The synclinal structure apparent in the Salado and Rustler structure maps began no earlier than Salado time and ended prior to Dewey Lake Red Beds time (late Permian). Probably the total development of this structure occurred during deposition of the Dewey Lake Red Beds.

There is no evidence of movement of any of the Castile or Salado halite at the present time, although some halite at the top of the Salado has been removed by ground water.

\subsection{Selected References}

J. E. Adams, "Upper Permian Ochoan Series of Delaware Basin, West Texas and Southeastern New Mexico," American Assn of Petroleum Geologists Bull 28(11):15961625 (1944).

R. Y. Anderson, W. E. Dean, Jr., D. W. Kirkland, and H. I. Snider, "Permian Castile Carved Evaporite Sequence, West Texas and New Mexico," GSA Bull 83:59-86 (1972).

R. Y. Anderson and D. W. Powers, "Salt Anticlines in Castile-Salado Evaporite Sequence, Northern Delaware Basin," in Geology and Mineral Deposits of Delaware Basin and Adjacent Areas, Circular 159 (Santa Fe, NM: NM Bureau of Mines and Mineral Resources, 1978), pp 79-84.
G. O: Bachman, "Cenozoic Deposits of Southeastern New Mexico and An Outline of the History of Evaporite Dissolution," USGS J of Res 4(2):135-149 (1976).

G. O. Bachman, Regional Geology and Cenozoic History of Pecos Region, Southeastern New Mexico, Open-File Report 80-1099 (USGS, 1980).

A. L. Brokaw, C. L. Jones, M. E. Cooley, and W. H. Hays, Geology and Hydrology of the Carlsbad Potash Area, Eddy and Lea Counties, New Mexico, Open-File Report USGS-4339-1 (USGS, 1972).

C. L. Jones, The Occurrence and Distribution of Potassium Minerals in Southeastern New Mexico, NM Geol Soc Guidebook, 5th Field Conf (1954), pp 107-112.

C. L. Jones, Salt Deposits of Los Medaños Area, Eddy and Lea Counties, New Mexico (with sections on Ground Water Hydrology by M. E. Cooley and Surficial Geology by G. O. Bachman), Open-File Report USGS-4339-7 (1973).

C. L. Jones, Test Drilling for Potash Resources: Waste Isolation Pilot Plant Site, Eddy County, New Mexico, Open-File Report 78-592, vol 1 and 2 (USGS, 1978).

C. L. Jones, Geologic Data for Borehole ERDA-6, Eddy County, New Mexico, Open-File Report 81-468 (USGS, 1981).

C. L. Jones, C. G. Bowles, and K. G. Bell, Experimental Drill Hole Logging in Potash Deposits of the Carlsbad District, New Mexico, Open-File Report (1960).

P. B. King, "Permian of West Texas and Southeastern New Mexico," American Assn of Petroleum Geologists Bull 26(4):535-763 (1947).

S. J. Lambert, "Geochemistry of Delaware Basin Ground Waters," in Geology and Mineral Deposits of Ochoan Rocks in Delaware Basin and Adjacent Areas, Circular 159 (Santa Fe, NM: NM Bur of Mines and Minerals, 1978), pp 33-45.

W. B. Lang, Geology of the Pecos River Between Laguna Grande de La Sal and Pierce Canyon, New Mexico State Engineer 12th and 13th Biennial Rpt (1938).

S. S. Oriel, D. A. Myers, and E. J. Crosby, "West Texas Permian Basin Region," in Paleotectonic Investigations of the Permian System in the United States, USGS Prof Paper 515, pp 21-60 (1967).

D. W. Powers, S. J. Lambert, S-E. Shaffer, L. R. Hill, and W. D. Weart, ed, Geological Characterization Report, Waste Isolation Pilot Plant (WIPP) Site, Southeastern New Mexico, SAND78-1596, vol I (Albuquerque, NM: Sandia Laboratories, 1978).

R. P. Snyder, "Geologic Data for Borehole WIPP-11," in Basic Data Report for Drillhole WIPP-11 (Waste Isolation Pilot Plant-WIPP), SAND79-0272 (Albuquerque, NM: Sandia National Laboratories, 1982), pp 5-23.

J. D. Vine, "Surface Geology of the Nash Draw Quadrangle, Eddy County, New Mexico," USGS Bull 1141-B (1963). 


\section{Site Deformation}

\subsection{Borehole Data}

The DZ was initially identified on seismic reflection lines and confirmed by later drilling. The boreholes, cores, seismic lines, and regional geologic structure form the data base for the $\mathrm{DZ}$ interpretation.

Figure 3-1 shows the location of those boreholes in the DZ that penetrate the Castile Formation. Figures 3-2 and 3-3 are borehole log correlations of the Salado and Castile Formations along the two lines on Figure 3-1. The correlations are tied to sealevel.
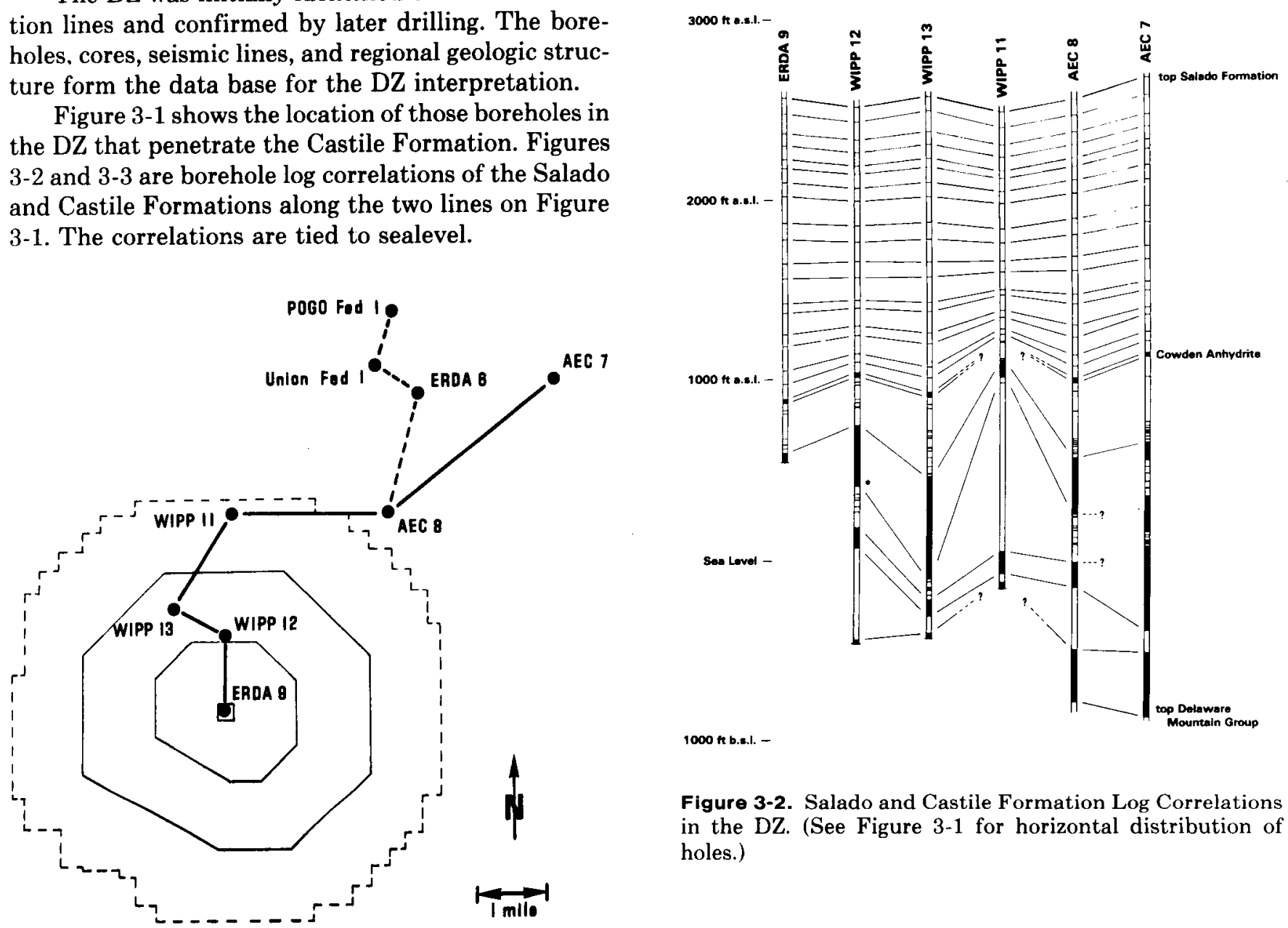

$1000 \mathrm{n}$ b.s.1. -

Figure 3-2. Salado and Castile Formation Log Correlations in the DZ. (See Figure 3-1 for horizontal distribution of holes.)

Figure 3-1. Boreholes in the DZ That Penetrate the Castile Formation 


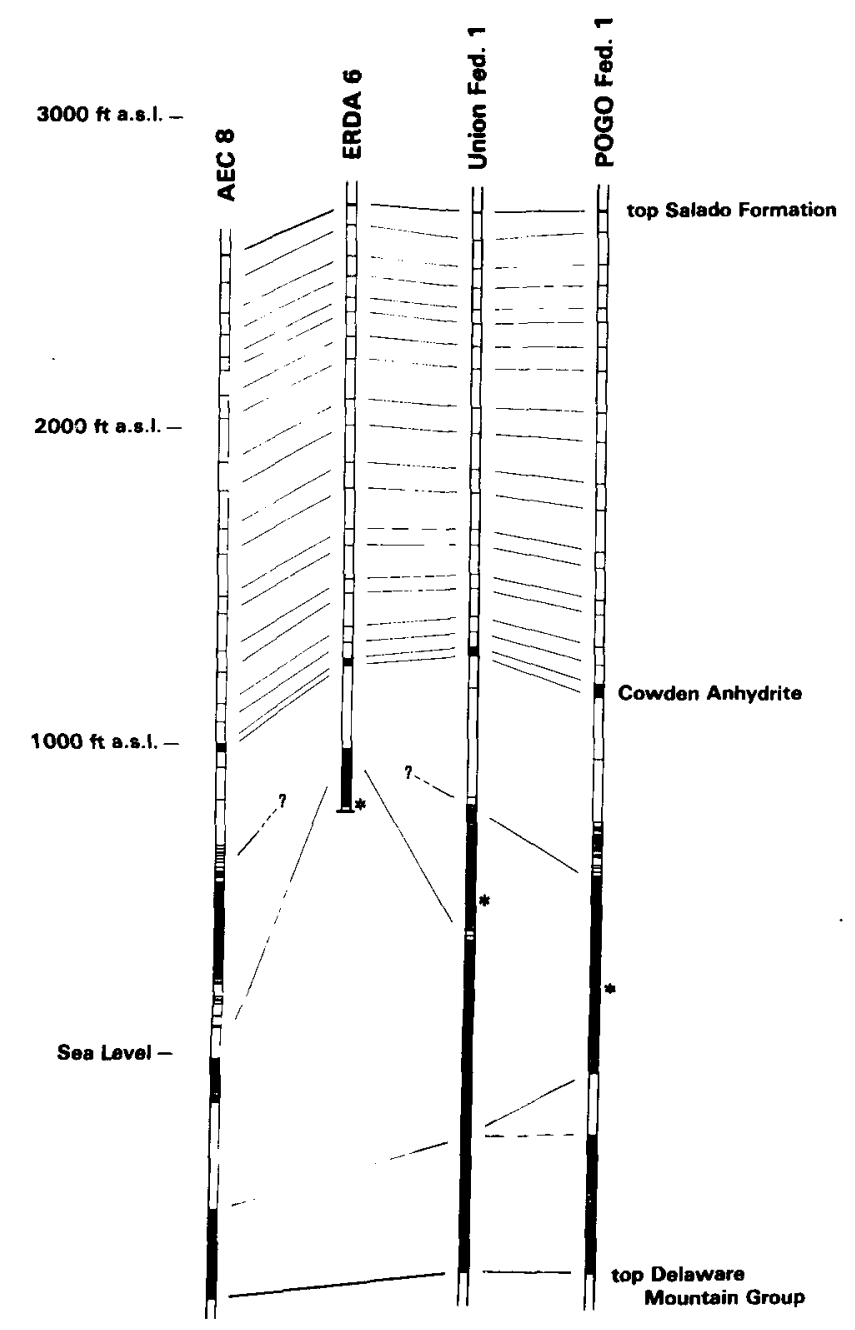

$1000 \mathrm{ft}$ b.s.l. -

Figure 3-3. Salado and Castile Formation Log Correlations in the DZ. (see Figure 3-1 for horizontal distribution of holes.)

Within the Salado Formation, the distinctive log character can be used to identify particular stratigraphic horizons. Log correlation is straightforward and easy. The Salado Formation correlations on Figures 3-2 and 3-3 are convenient wiggles on the compensated neutron density logs selected primarily because of the spacing of stratigraphic markers on these logs. Except for the Cowden Anhydrite in WIPP 11, the units are present on all the logs. The Cowden Anhydrite in WIPP 11 was not cored, and the drill cuttings over this interval were not described. Based on the acoustic and density logs, this interval is either not present or is greatly altered. Borehole WIPP 11 (and to a lesser extent ERDA 6 and WIPP 12) exhibits a thinning in the lower half of the Salado Formation. This thinning at WIPP 11 is shown in Figure 3-4, which is a tracing of the borehole-compensated acoustilogs from AEC 8 and WIPP 11 (similar relations are evident on the compensated neutron density logs). The logs are correlated, and the relative thinning of intervals between markers is plotted along the left side of the figure.

Within the Castile Formation DZ, the logs can be used to distinguish between halite and anhydrite, but it is generally not possible to identify specific stratigraphic horizons on the basis of log character alone. In undisturbed areas the logs can be reliably correlated because the units are laterally persistent and changes are gradational. Examples of such correlations are given in Snider (1966). Within disturbed areas, log identification within the Castile Formation may be less certain.

On Figures 3-2 and 3-3, the Castile Formation is divided into dark and light intervals. The dark intervals are primarily anhydrite; the light intervals are primarily halite. The distinction was made through the use of the compensated neutron density logs and may locally differ from core descriptions or a more thorough multilog analysis. The asterisks indicate occurrences of brine. All of the pressurized brine encounters in the Castile Formation of the northern Delaware Basin have been in disturbed areas.

Structural deformation is locally intense within the Castile Formation (Figures 3-2 and 3-3). There are vertical displacements of hundreds of feet and thickness variations of hundreds of percent. In AEC 7 there are four massive anhydrites with a probable repeat of AII; in POGO Fed. 1 there are two (the latter may be a depositional pinchout of HII along the reef margin). In ERDA 6, the uppermost Castile anhydrite unit was identified from core as AII (Anderson, 1976), and AIII is missing. The sequence of thinner anhydrite beds above AIII and in HII is not always observed within the $\mathrm{DZ}$.

At WIPP 11 the first massive anhydrite encountered below AII (identified by distinct laminations in the core) is regarded as AI. If correct, then the top of AI is $\sim 225 \mathrm{ft}$ above its expected elevation. This observation is significant because it implies one of two things. Either AI is involved in the $\mathrm{DZ}$ salt flowage deformation, or the underlying Delaware Mountain Group is deformed, perhaps by faulting (as interpreted in Chap 2). 


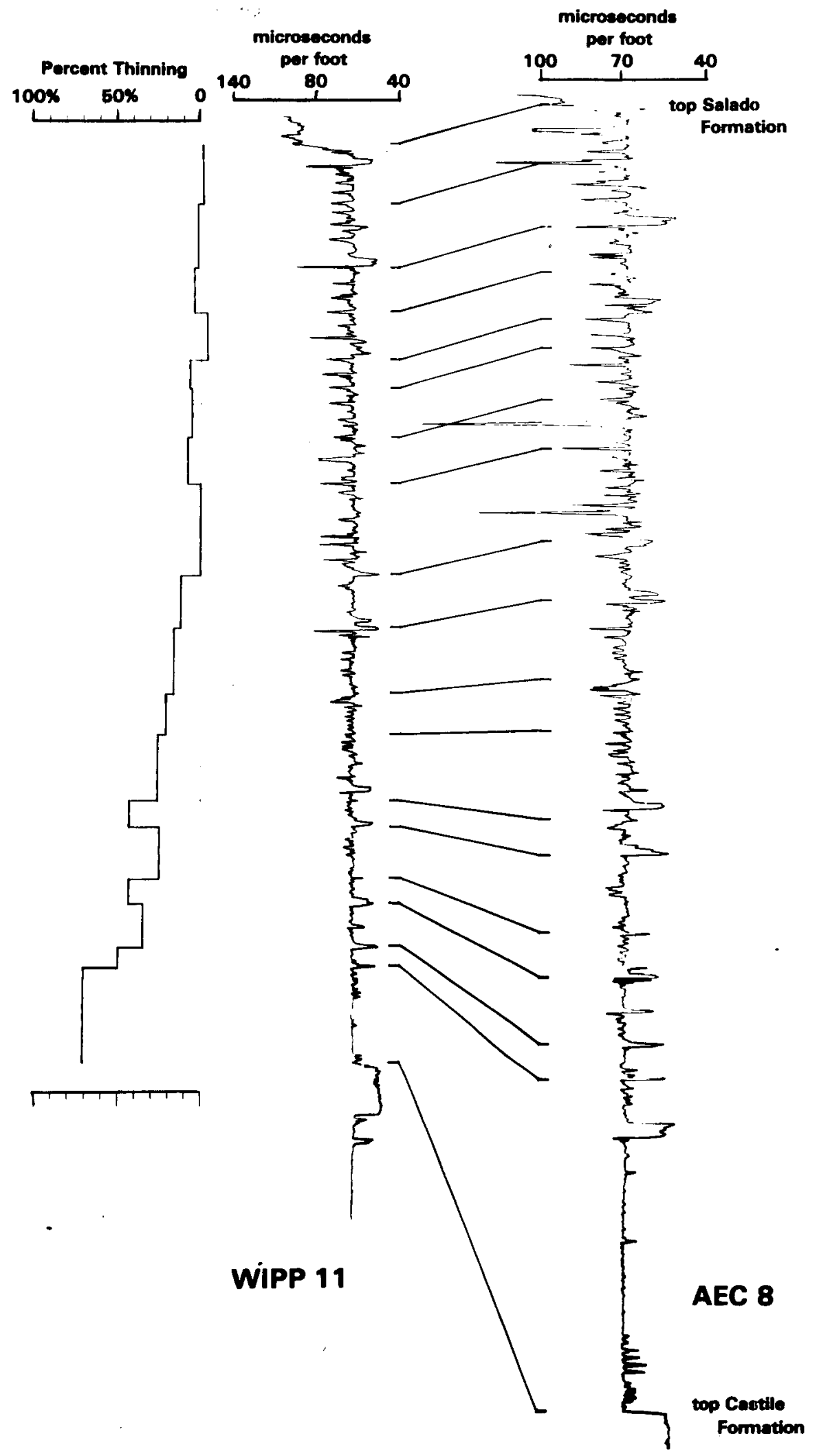

Figure 3-4. Acoustilog Correlation of the Salado Formation in AEC 8 and WIPP 11 
Further indication of some deformation in $\mathrm{AI}$ and possibly the Delaware Mountain Group is described in the preceding discussion of borehole data from the James Ranch anticline (Sec 1, T23S, R30E). However, not all disturbed areas are underlain by complex structure (compare Figures 3-13 and 3-14 in Sec 3.2.2) in the Delaware Mountain Group; the seismic reflection lines show relative continuity of the Cherry Canyon and Bone Spring events beneath the DZ.

Data from individual wells were used to establish the geologic section at the borehole. In regions of simple, gradational structure, the boreholes and the seismic lines can be used to interpret the actual form of the subsurface structures. In the heart of the DZ the geologic structure is too complex and the boreholes too widely spaced to apply these techniques. Even though the megascopic structures cannot be interpreted, the meso- and microscopic style of deformation is represented by existing borehole, seismic, and petrographic data. Overall, the $\mathrm{DZ}$ is best described as a structural complex.

\subsection{Seismic Reflection}

\subsubsection{Data}

The WIPP site was extensively surveyed with the seismic reflection technique in 1976, 1977, and 1978. These data provide good resolution of the seismic time structure from the top of the Castile Formation to the Bone Spring Formation. Reflections from shallower and deeper horizons are too unreliable to map with these data. High-resolution seismic experiments were conducted in 1979 and 1980 to determine if these techniques could resolve the shallower horizons, but results were generally discouraging. Results of the detailed gravity survey of 1979-1981 indicate that at least part of the problem with high-resolution techniques stems from lateral variations in velocity and density within the formations. These lateral variations are discussed in the following section on the WIPP-site gravity field.

The seismic reflection data were collected during four sequential Vibroseis surveys. Table 3-1 lists all the seismic surveys, including the high-resolution experiments. Figure 3-5 is a composite line location map of the four Vibroseis surveys.

Field and processing parameters and uninterpreted seismic sections from the 76SAN, 77X, and 78Y surveys are in Hern et al (1979). An interpretation of the 78GG survey is given in Bell and Murphy and Associates, Inc. (1979), but the data are not included.

Table 3-1. WIPP Site Seismic Surveys

\begin{tabular}{clc} 
Year & Designation & Line Miles \\
\hline Vibroseis & & \\
\hline 1976 & $76 \mathrm{SAN}$ & 25 \\
1977 & $77 \mathrm{X}$ & 47 \\
1978 & $78 \mathrm{Y}$ & 5 \\
1978 & $78 \mathrm{GG}$ & 74 \\
High-Resolution & & \\
1979 & $79 \mathrm{EX}$ & 1 \\
1980 & $80 \mathrm{EX}$ & 1.3 \\
\hline \hline
\end{tabular}

The following briefly summarizes the field and processing parameters used in the WIPP Vibroseis seismic surveys. The 76SAN was conducted by Dresser Olympic and supervised by Collin McMillan of the Permian Basin Exploration Company (Hern et al, 1979). This survey used 48 receivers at a 220 -ft spacing in a 5940-880-0-880-5940 split-spread configuration (processed as a 24 -fold CDP stack). The source was four vibrators, distributed over $220 \mathrm{ft}$, generating a sweep of 8 to $30 \mathrm{~Hz}$. The signal was sampled at intervals of $4 \mathrm{~ms}$. These parameters are fairly common to petroleum exploration in the region.

The 76SAN sections do not show reliable events within the Castile Formation, because of the field parameters, which were selected to resolve deeper structures of interest to petroleum geologists. On the sections, the dominant frequency is near $25 \mathrm{~Hz}$ and the vertical resolution should not be better than $\pm 56 \mathrm{ft}(10 \%$ of one wavelength at $14000 \mathrm{ft} / \mathrm{s})$. The 76 SAN sections show fairly consistent parallel events over most of the site, the western edge of the DZ near shotpoint 25 of line 76SAN3, and an area of structural complexity to the southwest of the site (shotpoints 135 through 160 of line 76SAN2).

The 76SAN data differ significantly in both resolution and seismic character (wiggle shape) from the later surveys. The 76SAN sections were checked for consistency with the interpretation of these later surveys, but they were not incorporated into the timestructure and isochron contour maps (Figures 3-6 through 3-12). 


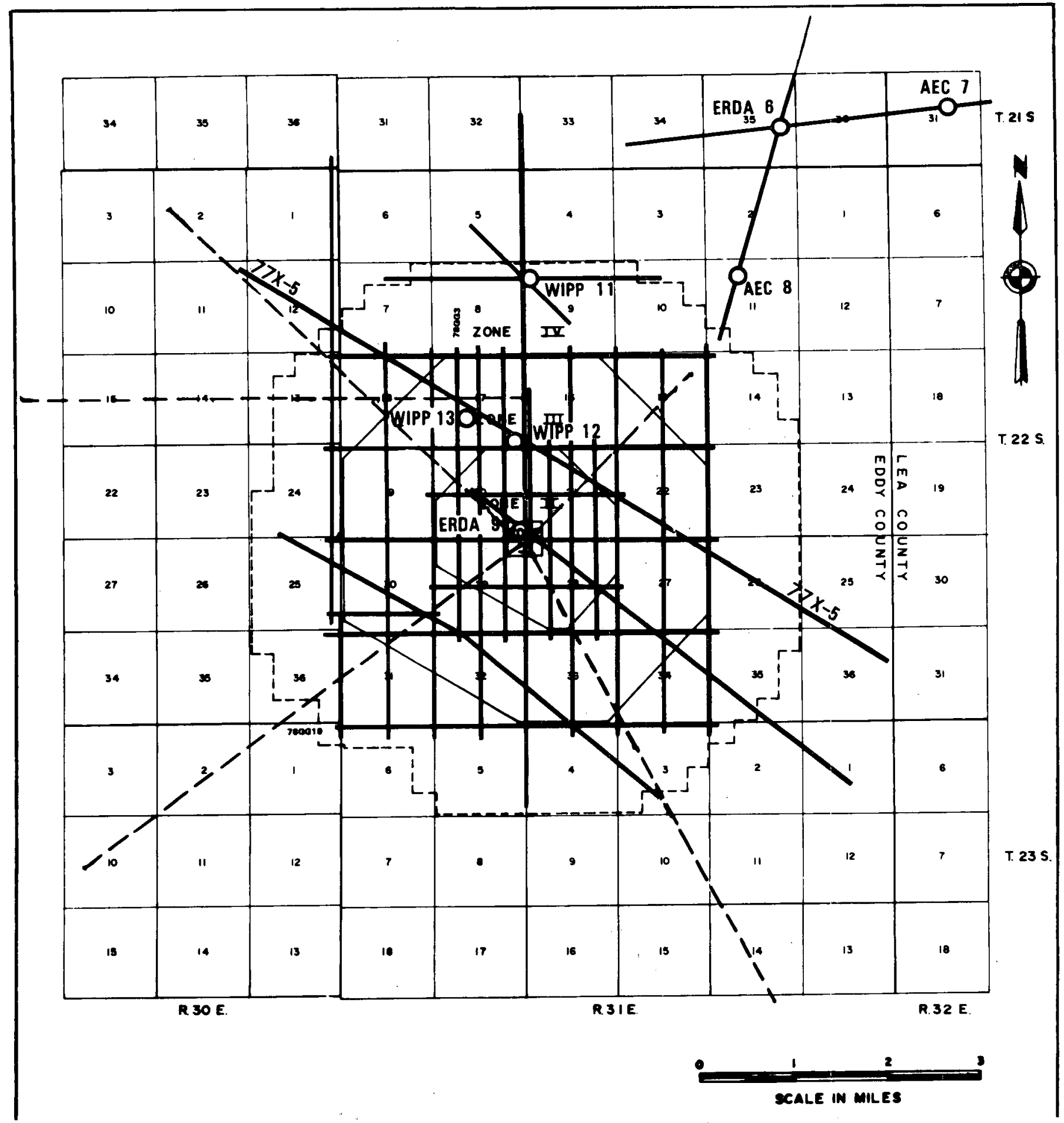

Figure 3-5. Vibroseis Line Locations. (The three heavy lines are included as Figures 3-13, 3-14, and 3-15 of this report.) 


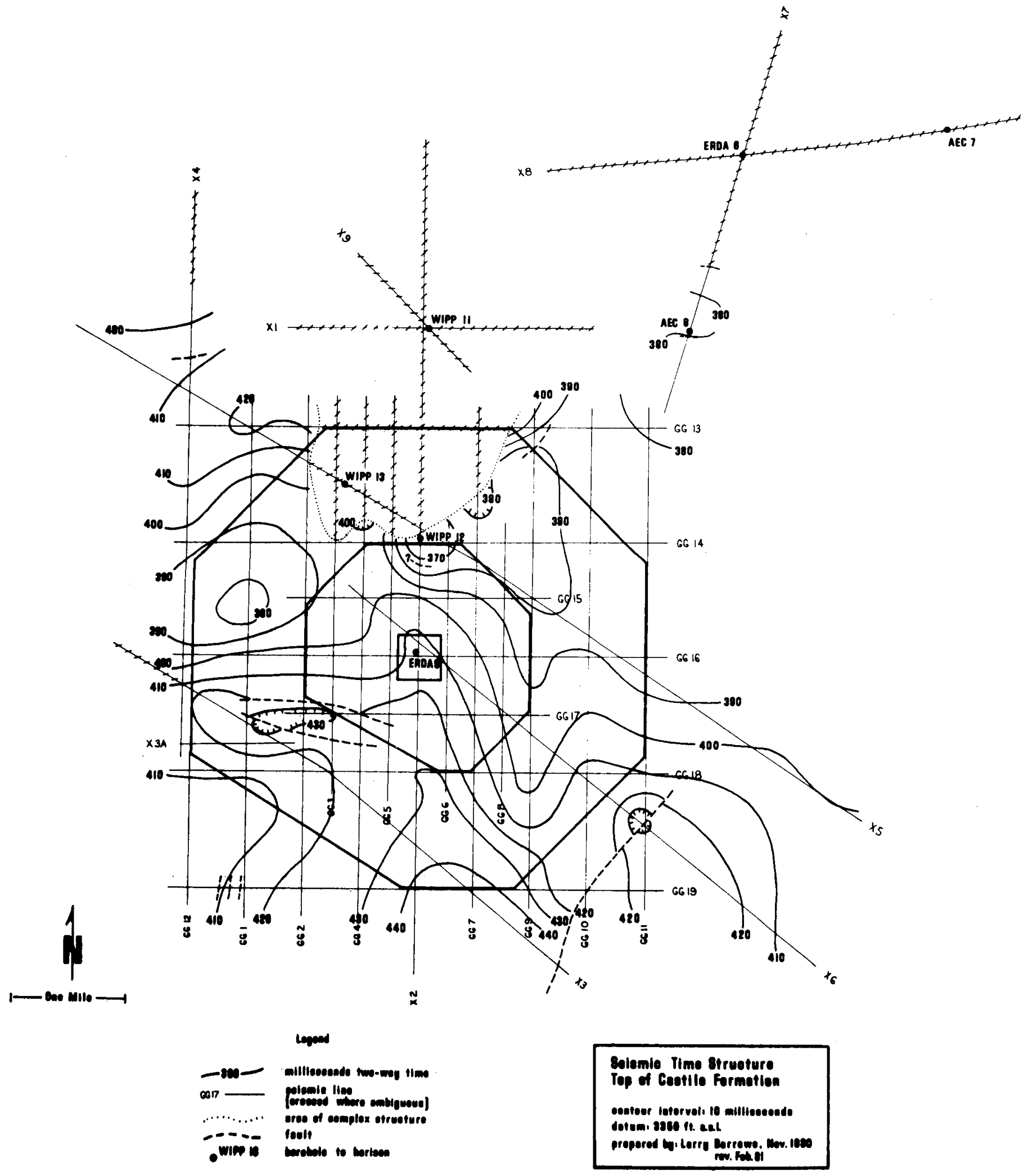

Figure 3-6. Seismic Time Structure - Top of Castile Formation 


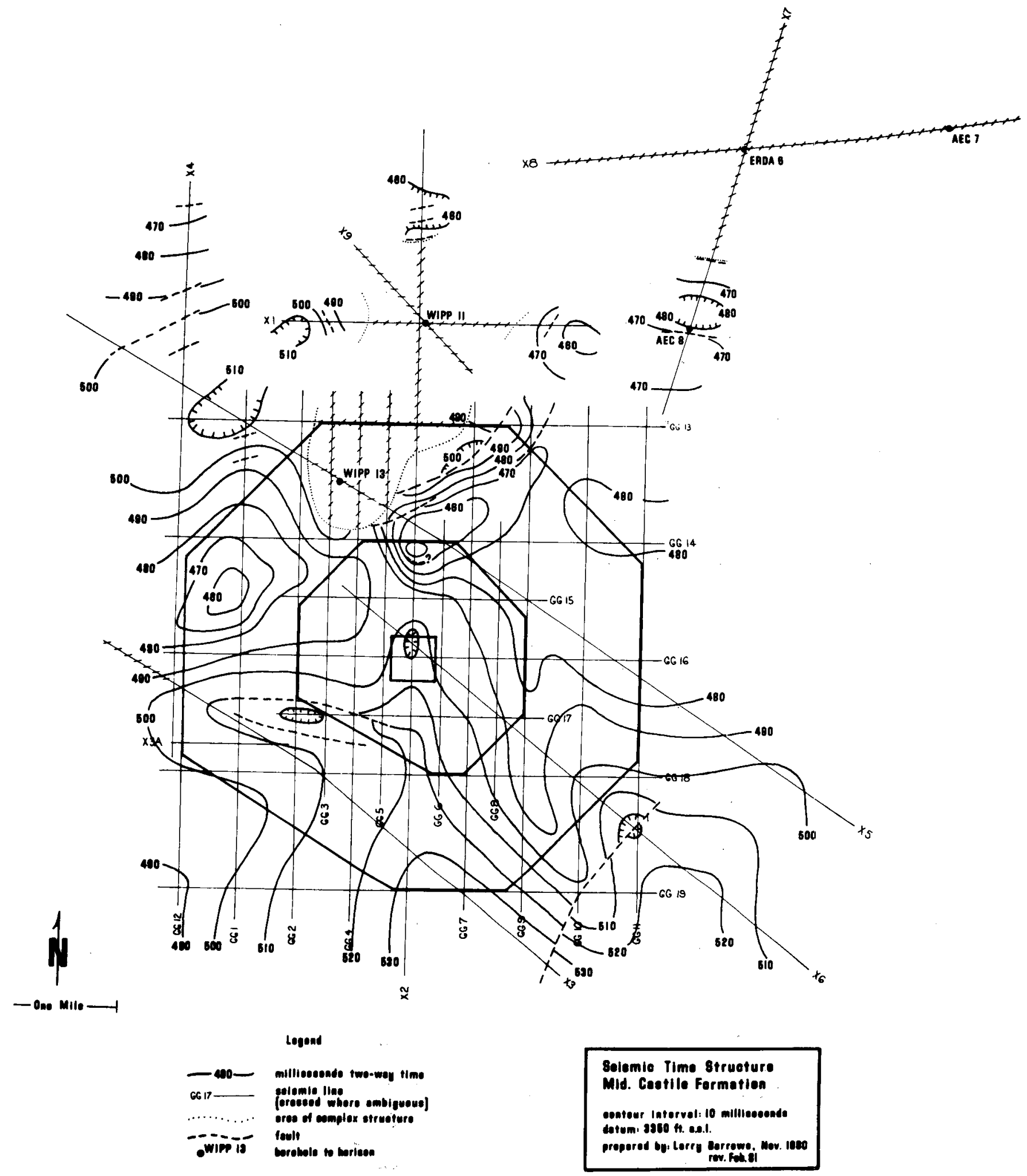

Figure 3-7. Seismic Time Structure - Mid-Castile Formation 


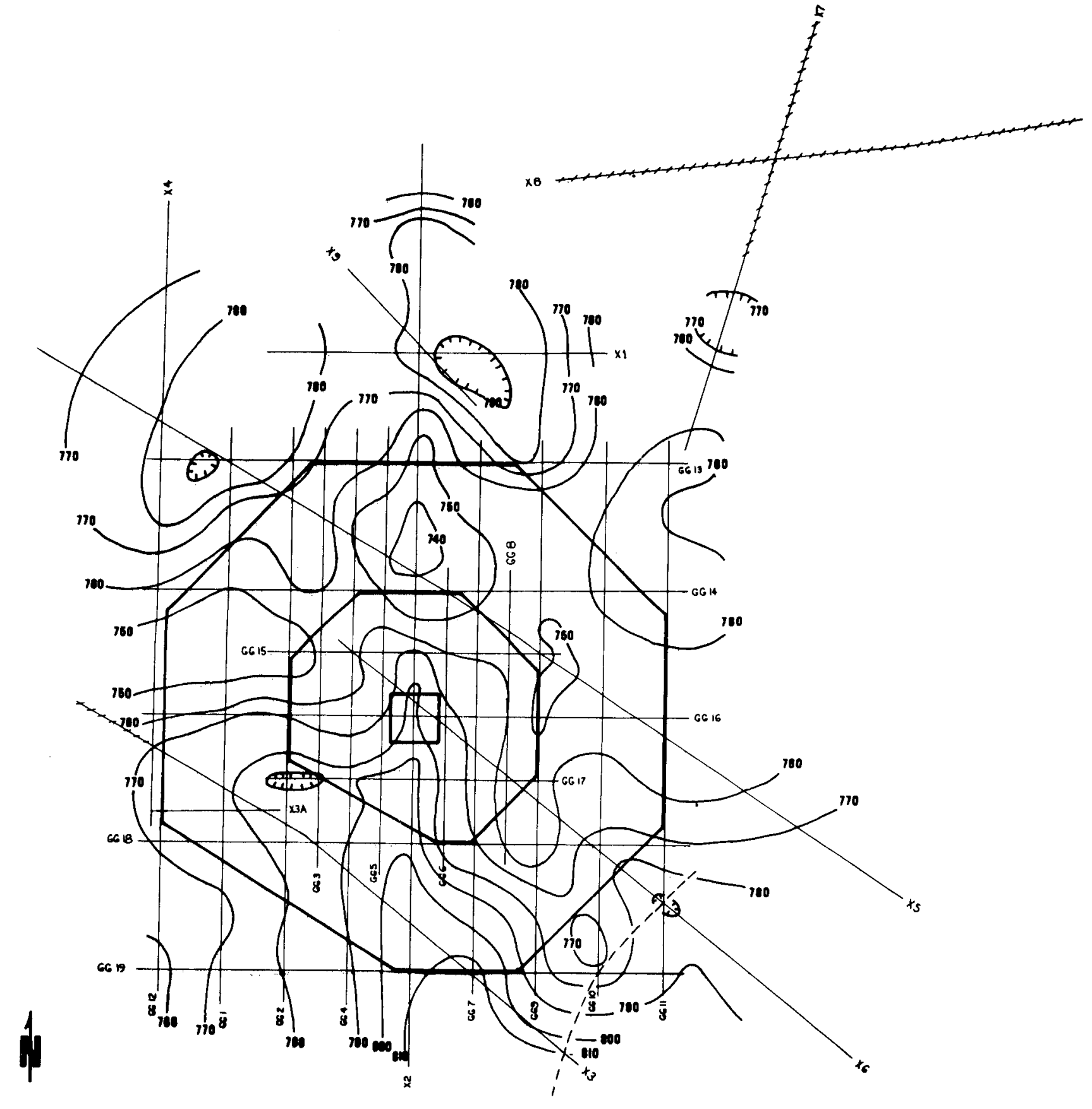

$\longrightarrow$ m miln $\longrightarrow$

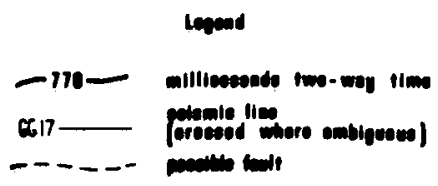

Elemio tine strueture

Top of Chorry Ganes Formation

Contour latermal 10 milligeneonde

Cotumi asce if. ceol.

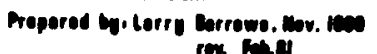

Figure 3-8. Seismic Time Structure - Top of Cherry Canyon Formation 


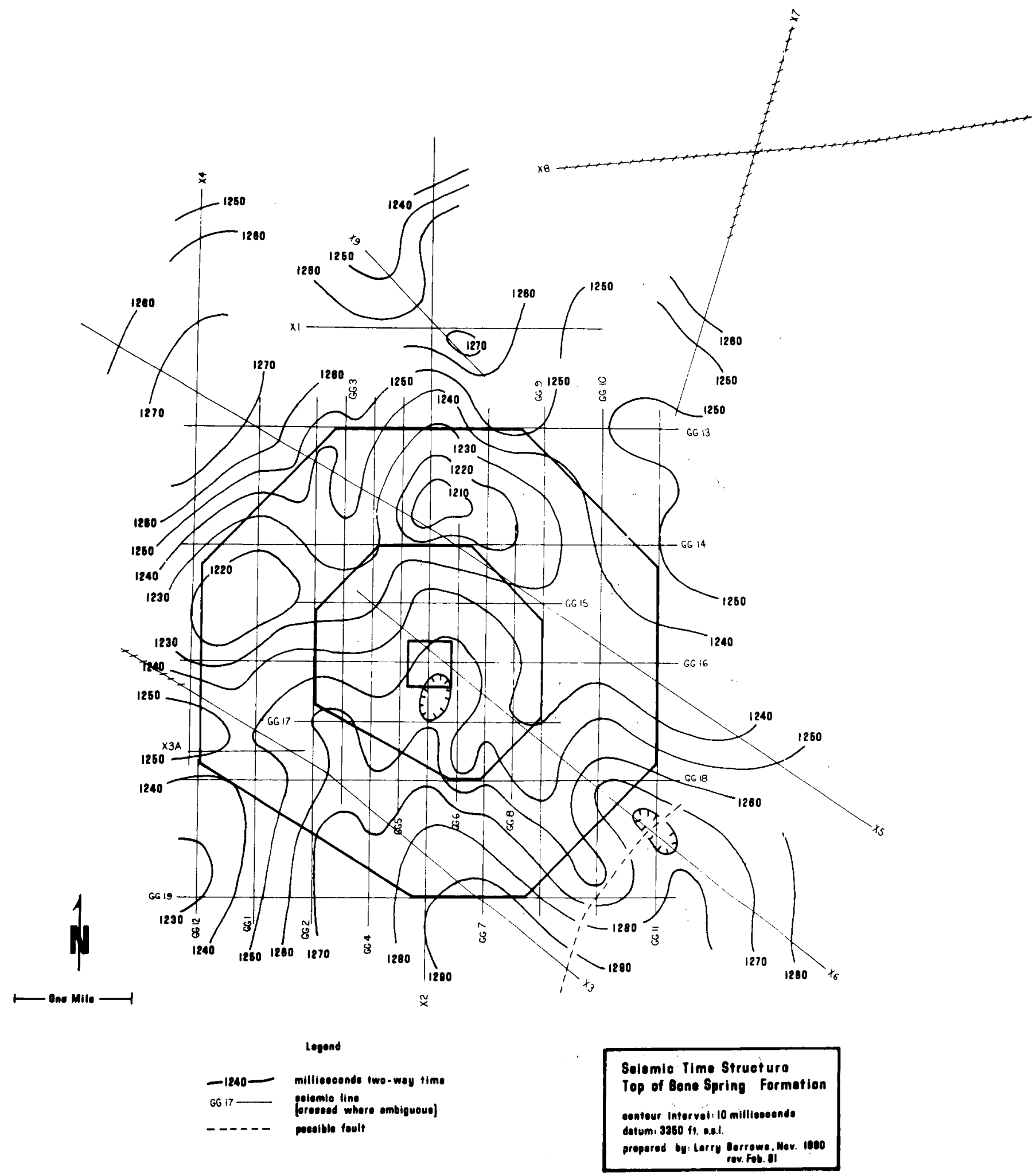

Figure 3-9. Seismic Time Structure - Top of Bone Spring Formation 


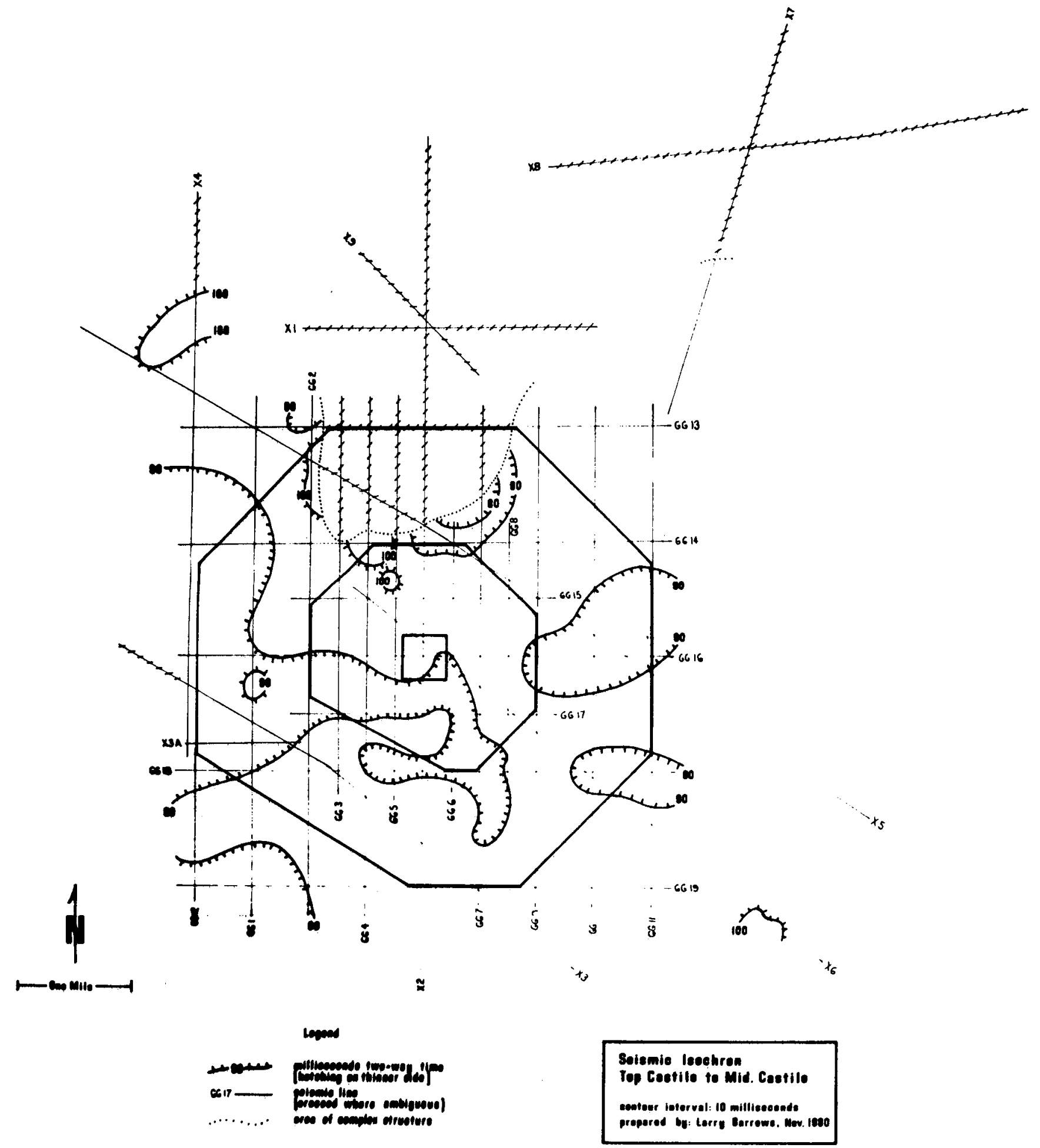

Figure 3-10. Seismic Isochron - Top Castile to Mid-Castile 

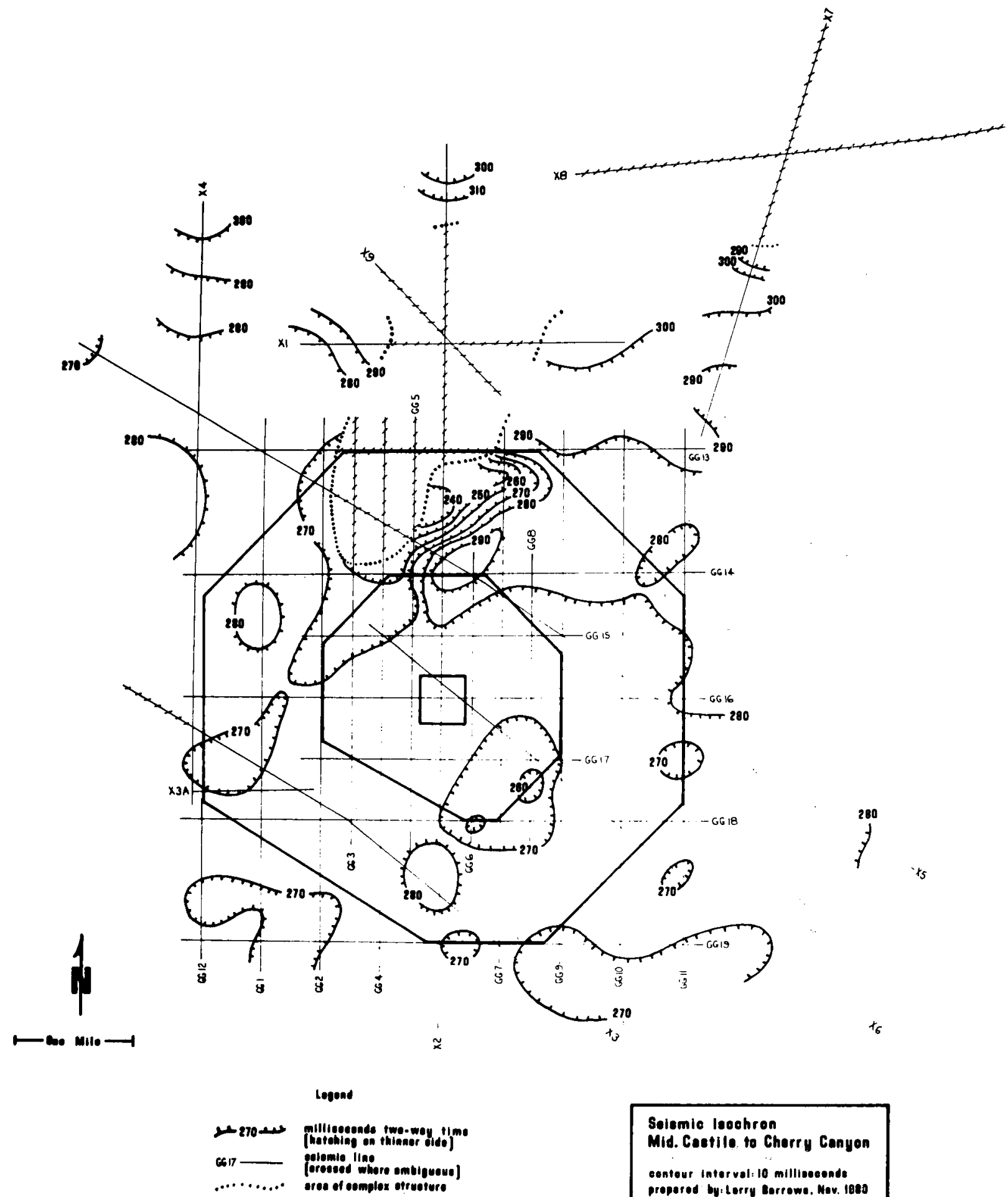

Selemic leoohron Mid. Castile to Cherry Canyen

Figure 3-11. Seismic Isochron - Mid-Castile to Cherry Canyon 


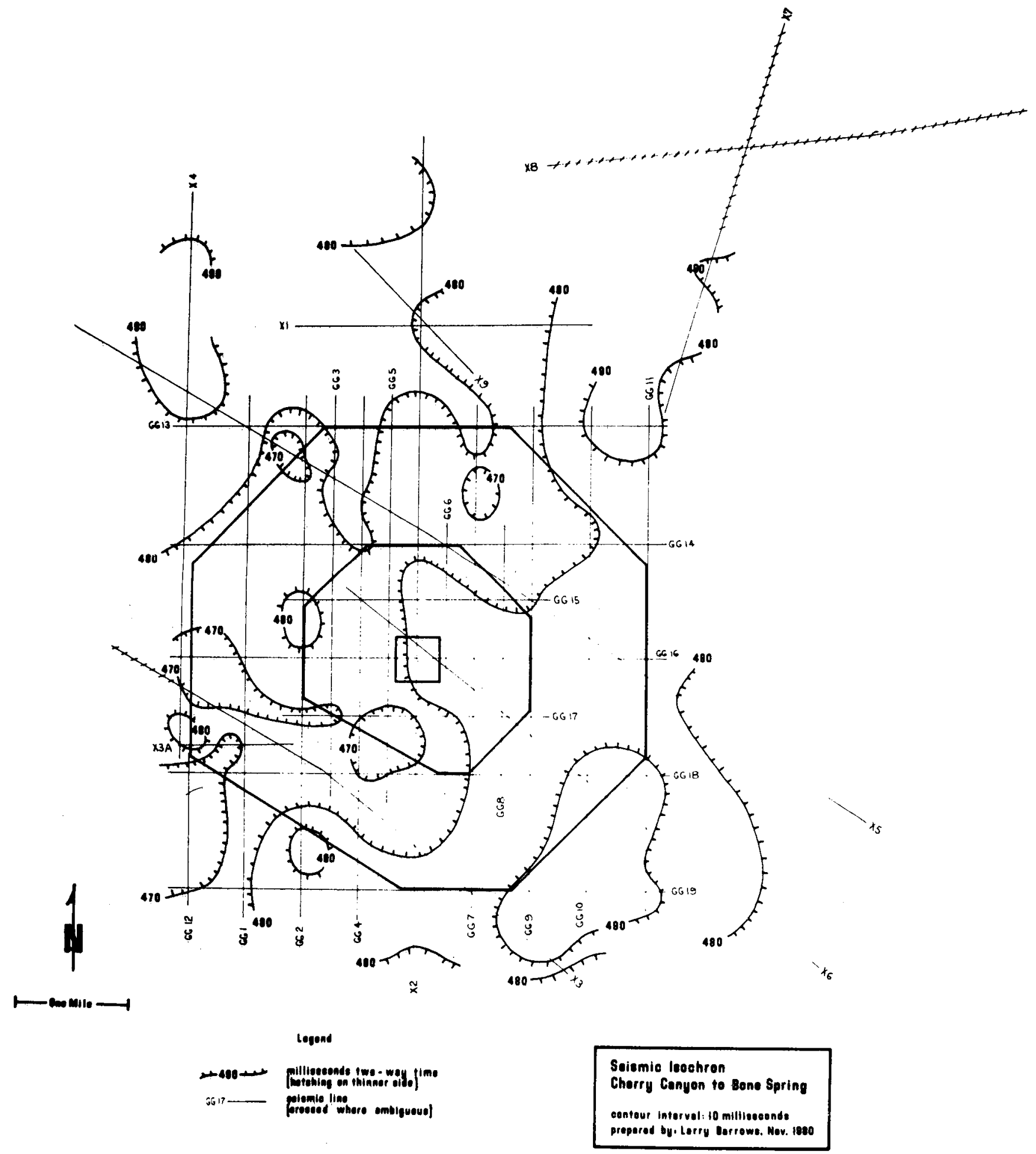

Figure 3-12. Seismic Isochron - Cherry Canyon to Bone Spring 
The 77X survey was conducted by Dresser Olympic and supervised by John L. Hern of G. J. Long and Associates. For this and subsequent surveys, field techniques were modified from those of the 76SAN survey to obtain better resolution of the shallower horizons. The $77 \mathrm{X}, 78 \mathrm{Y}$, and $78 \mathrm{GG}$ surveys used 24 receivers at a spacing of $110 \mathrm{ft}$ in a split-spread configuration (processed as a 12-fold CDP stack). Vibrator sweep frequencies were increased to 25 to $100 \mathrm{~Hz}$, and the sample rate was increased to $2 \mathrm{~ms}$. The 77X and 78GG surveys both used a 1650-440-0440-1650 split-spread configuration with three to four vibrators (depending on how many were operational) stepped over $220 \mathrm{ft}$. The $78 \mathrm{Y}$ survey used a 1440-1100-110-1440 configuration with one vibrator stepped over $110 \mathrm{ft}$.

The 77X sections indicate the seismic features of interest at the WIPP site and extend the data beyond WIPP site Zone III. By themselves the 77X lines were too widely spaced to allow a reliable threedimensional interpretation. They were worked into the interpretation of the 78GG sections and form part of the data from which the following maps were made.

The 78Y survey was run by CXC Inc. and processed by Seismic and Digital Concepts, Inc., both of Houston, Texas. John L. Hern of G. J. Long and Associates managed the survey.

The field techniques were similar to the $77 \mathrm{X}$ and $78 \mathrm{GG}$ surveys, except that the $78 \mathrm{Y}$ survey used only one vibrator instead of three to four and a shorter near-offset distance (110 ft vs $440 \mathrm{ft}$ ). The processed sections show reliable events, but they are not as clear as those from the $77 \mathrm{X}$ and $78 \mathrm{GG}$ surveys. The relatively better quality of data from these other surveys is likely due to the repression of surface noise by multiple vibrators.

The $78 \mathrm{Y}$ lines coincide with some of the $78 \mathrm{GG}$ lines. The 78GG sections were used in the seismic interpretation because of the better apparent quality of data and because the redundant 78GG sections are part of a larger data set. The interpretation was checked against the 78Y sections; no inconsistencies were found.

The 78GG survey was conducted by Grant Geophysical Corp. (formerly Dresser Olympic) for Bechtel National Inc. and supervised by Bell and Murphy and Associates, Inc. (1979). Twenty lines cover WIPP site Zones I, II, and III at an approximate spacing of $1 / 4 \mathrm{mi}$. Field parameters were identical to the $77 \mathrm{X}$ survey, except that the vibrators used an upsweep (frequency increasing with time) instead of a down- sweep. The 78GG survey also included two experimental lines (78GG5X and 78GG6X) with a receiver spacing of $55 \mathrm{ft}$ and a 935-330-0-330-935 split-spread configuration. The processed sections of these experimental lines revealed no data that were not already contained in the normal sections.

\subsubsection{Interpretation}

The 78GG survey forms the basis for the present interpretation. The $77 \mathrm{X}$ sections were used to verify and expand this interpretation.

The processed seismic sections, along with the boreholes, core descriptions, and regional geology, form the basic data set for interpreting subsurface structures at the WIPP site. It was thought that the gravity field would provide significant additional control on the interpretation. However, the gravity field was found to be dominated by lateral density variations in relatively undeformed shallower strata; gravity data are interpreted in a later section.

Figures 3-13, 3-14, and 3-15 are three representative interpreted seismic sections. Locations of lines 77X5, 78GG3, and 78GG19 are indicated on Figure 3-5. Four interpreted seismic horizons and the tie to boreholes WIPP 12 and WIPP 13 are indicated on the sections. (The four interpreted horizons are identified later in Table 3-3.)

The interpretive process involves more than isolated seismic sections. Each seismic horizon is initially identified with one of the continuous series of troughs on the individual traces (vertical wiggly lines) that make up a total section. The horizons are carried along the section to intersecting cross lines. The two-way travel times are transferred to the intersecting section, and the horizons are carried along this section to the next intersecting cross line. This process is repeated until the horizons are tied back to themselves on the original section. In this way the interpretation is developed as a system of closed loops. Seismic two-way times are read off the sections, posted on shotpoint maps, and contoured. Structural features (e.g., faults) are correlated between adjacent or intersecting sections, located on the shotpoint maps, and worked into the contours. The incremental two-way time between horizons is also posted and contoured as isochrons. Finally, the resulting time-structure and isochron maps are examined for geologic consistency. The mutual cross-checks of the entire interpretive process result in maps that are more reliable than could be achieved with the sum of the individual pieces. 


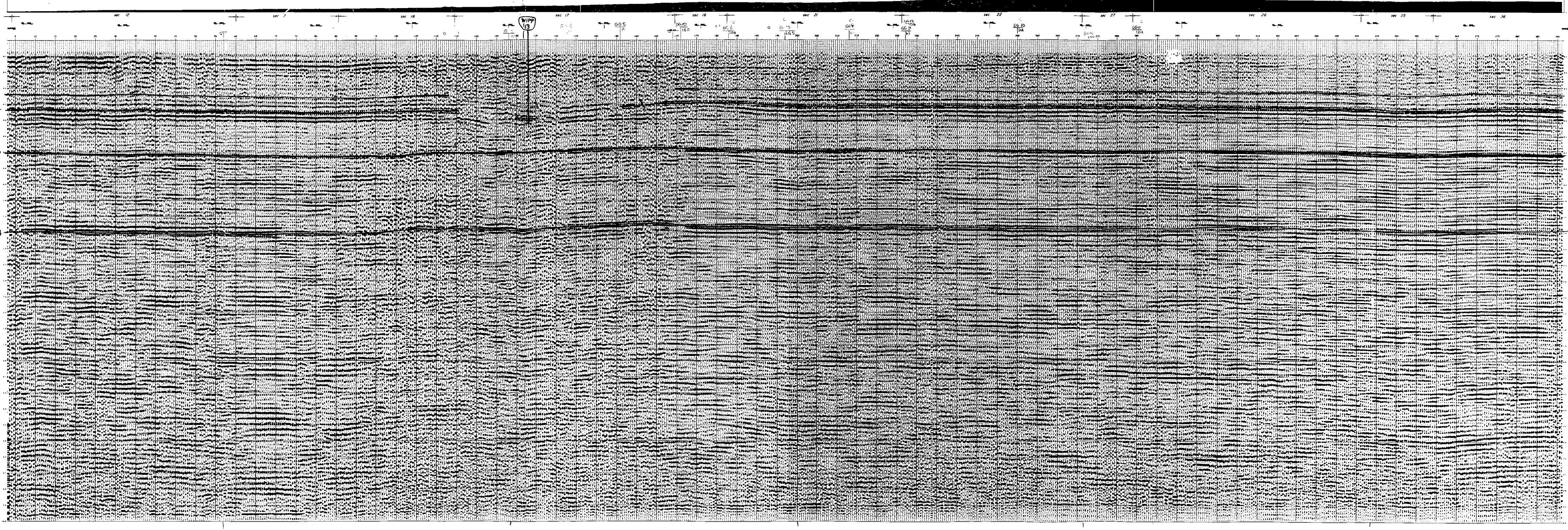




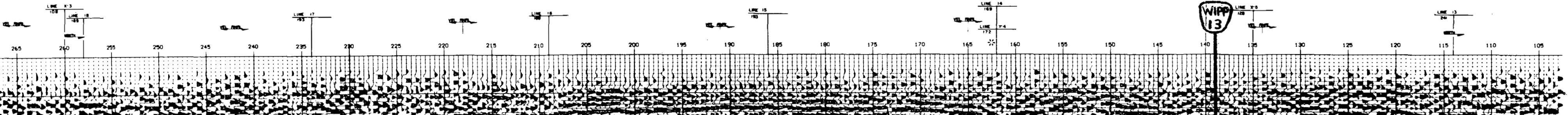

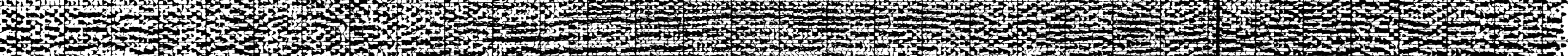

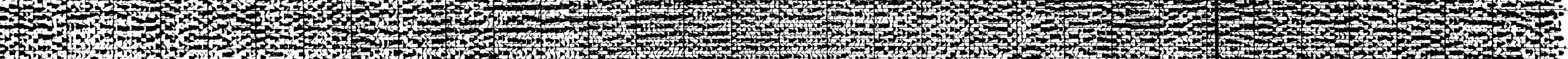
3.

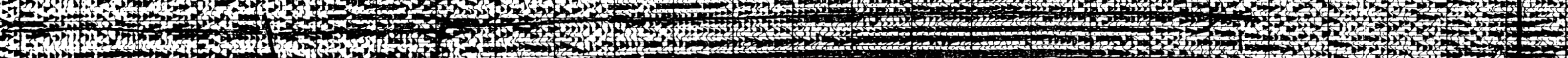

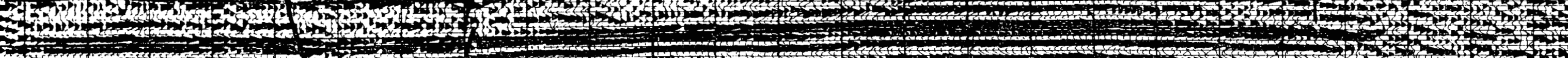

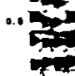

3.

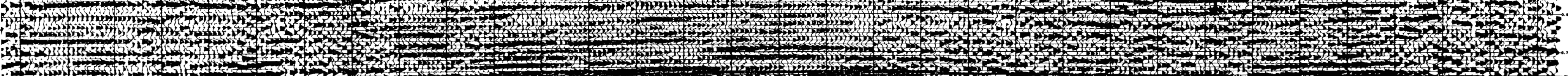

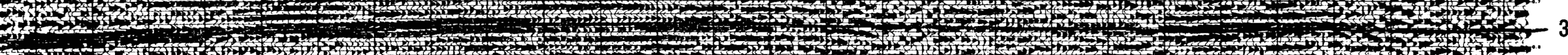
Tra

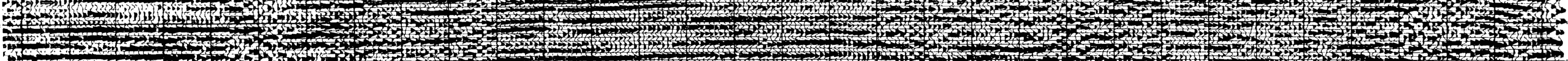

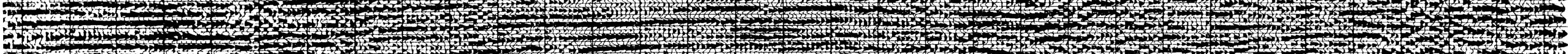

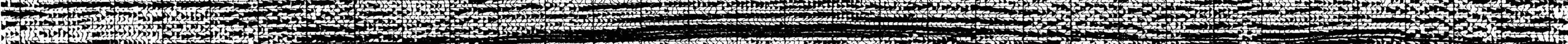

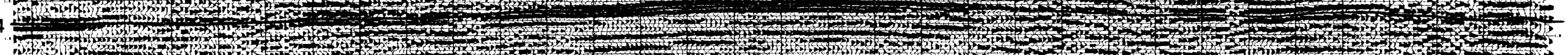
J

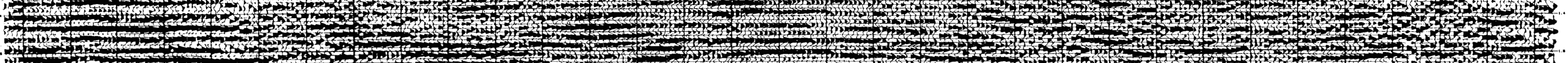
1.t. F

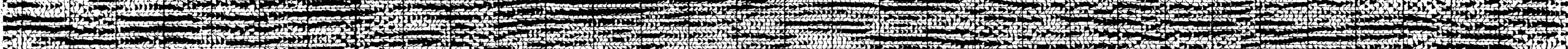

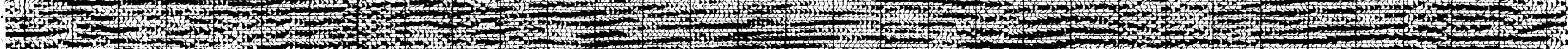
3.

uscouscruen

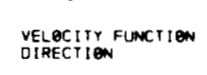

\section{GRANT}

U.S. DEPT. OF ENERG

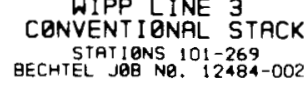
露 Fit: $=$

\section{$=$} $=$ $x=$ $=-10$ in $-=$ Aris 


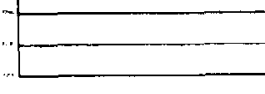 \\ $-\infty$

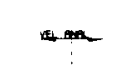

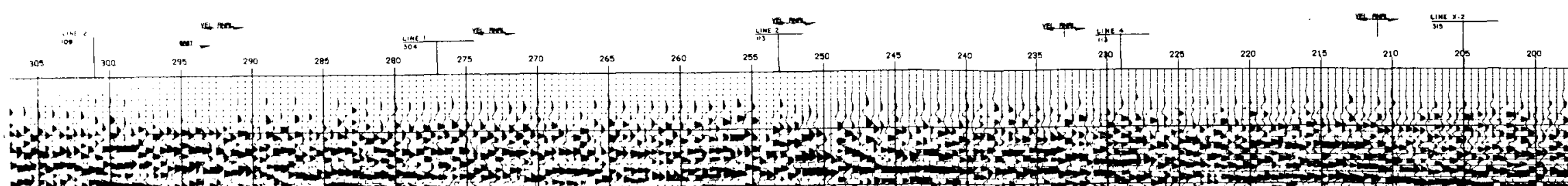

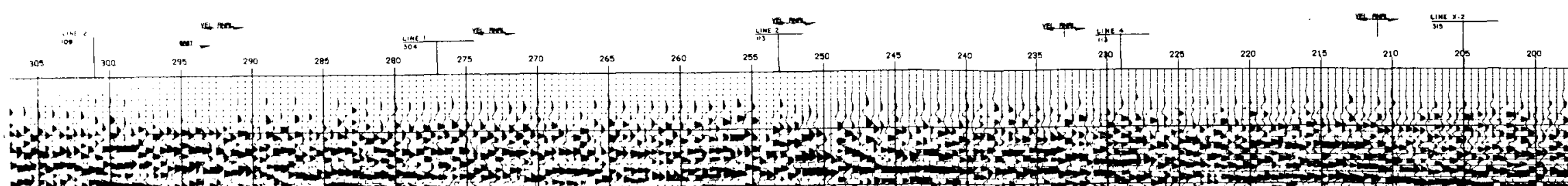

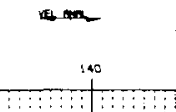

\section{cising}

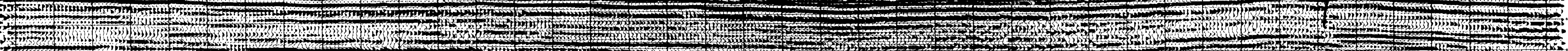

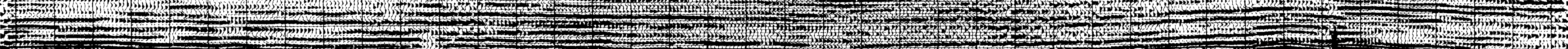

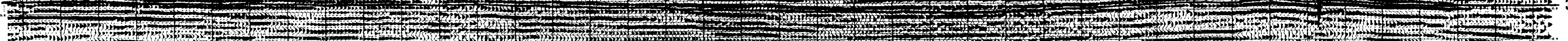

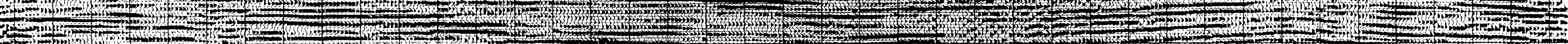

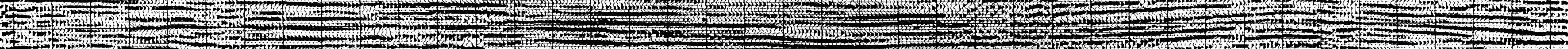

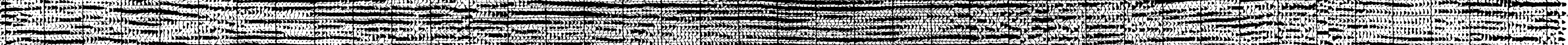

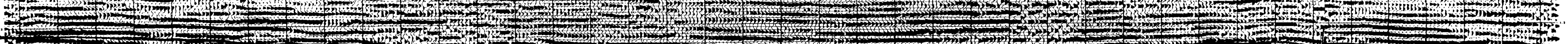

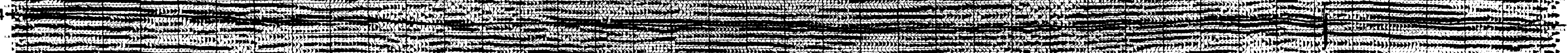

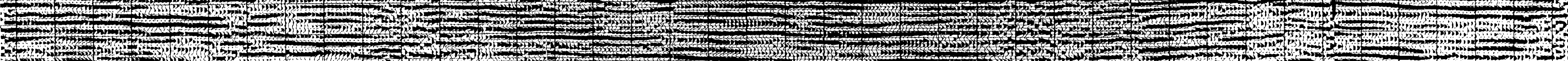

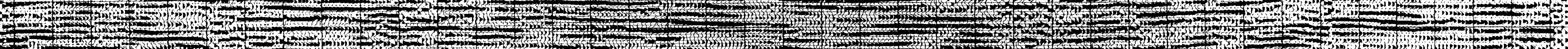

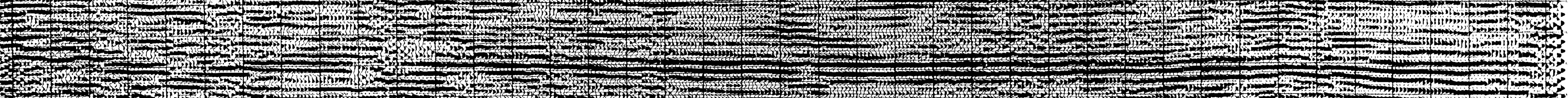
17.

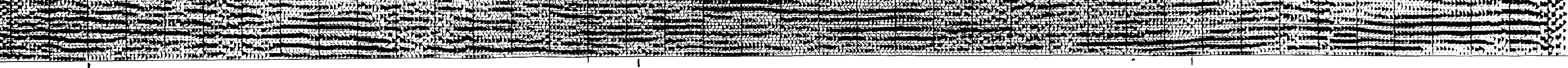


The mutual cross-checks also allow the interpreter to develop an understanding of the quality of data. The WIPP seismic time structure (Figures 3-6, 3-7, 3-8, and 3-9) and isochron maps (Figures 3-10, 3-11, and $3-12$ ) are regarded by this interpreter (Larry Barrows) as reliable.

Several features on the seismic time structure and isochron maps warrant further discussion. First, most of the site is characterized by broad, open, lowamplitude (10 to $40 \mathrm{~ms}$ of closure) folds. Except where shown on the maps, the events are continuous, indicating the absence of significant faults. Over most of the site the isochron maps are featureless, indicating uniform stratigraphic thicknesses.

There is a northeast-trending fault southeast of WIPP site Zone III. This feature is strong on lines 77X3, 77X6, 78GG11, and 78GG19; moderate on line 78GG10; and weak to nonexistent on lines 76SAN1, $77 \mathrm{X} 5$, and 78GG18. It appears to extend through the top of the Castile Formation and down into the underlying Delaware Mountain Group. This displacement is small (10 to $20 \mathrm{~ms}$ ) and shows no consistent offset. The arcuate map trace, lack of consistent offset, and absence of a fault indication at its projection onto line $77 \mathrm{X} 5$, all suggest this is not a major through-going tectonic feature. Figure 3-15 shows the feature on line 78GG19.

There is an east-trending elongated syncline in Sec 29, 30 of R31E, T22S. It is best seen on the two Castile Formation time-structure maps (Figures 3-6 and $3-7)$. The relief is $\sim 30 \mathrm{~ms}$ two-way time (210 $\mathrm{ft}$ at $14000 \mathrm{ft} / \mathrm{s})$. The sides of the syncline appear to be slightly ( 5 to $10 \mathrm{~ms}$ ) faulted. This fault indication can be seen on line 78GG3 (Figure 3-14). If the fault indications are valid, this feature is a small graben.

The largest anomaly on the seismic sections is the DZ. Seismic line 77X5 (Figure 3-13) is reasonably representative of data from this area. This line extends from a normal area across the $\mathrm{DZ}$ and back into a normal area. From shotpoints 112 through 160 the Castile horizon reflections are considered too unreliable to map. The seismic data are valid, but the geologic structures within the Castile Formation are too complex to map with the seismic technique. These conclusions are supported by the steep lamination dips, variable stratigraphic thicknesses, and petrographic features (e.g., recumbent folds, shear zones) exhibited by core. The seismic data indicate a blocky structure with abrupt dip changes and offsets (faults) between units. The seismic character (wiggle shape) changes, which indicates variations in thicknesses and/or acoustic properties. From shotpoints 160 through 190, Figure 3-13 indicates an anticlinal flexure on the mid-Castile horizon.

The use of seismic bright-spot techniques to detect brine pockets within the Castile Formation has been suggested. These techniques are based on the change in acoustic properties accompanying changes in the content (gas, oil, water) of pore spaces. Such acoustic variations sometimes cause changes in seismic character that can be correlated with a prospective geologic structure that indicates an oil or gas reservoir. Based on core examination, the WIPP 12 brine occurrence is from a few nearly vertical fractures within AIII. These fractures are not expected to produce an identifiable seismic signal. If the fractures are part of a spatially finite, pervasively fractured volume of anhydrite, the associated variations in bulk acoustic properties might produce a change in seismic character. This change would have to be distinguished from those resulting from the existing but unknown lateral variations in stratigraphic thicknesses. At this time the use of bright-spot techniques to detect brine pockets does not appear feasible.

The lateral extent of the $\mathrm{DZ}$ is best established from Figures 3-6, 3-7, 3-10, and 3-11. These maps show an "area of complex structure" within which the Castile Formation's geologic structures are too complex to map with the seismic technique. This area includes boreholes WIPP 13, WIPP 11, ERDA 6, AEC 7 , and is open to the northeast. Bordering this is an area where the Castile Formation horizons show salt flow structures and some faulting. Boreholes AEC 8, WIPP 12, and SCL Fed. No. 1 are in this peripheral region. The outer edge of the mapped flow structures is here taken as the limit of the DZ. This definition is necessarily ambiguous. It includes the anticline at WIPP 12, and may or may not include the anticline in Sec 19.

The seismically indicated $\mathrm{DZ}$ affects primarily the Castile Formation horizons. The underlying Cherry Canyon and Bone Spring horizons have reduced data quality, but are continuous enough to map. As noted below, the irregular seismic time structure on these horizons may be caused by velocity variations within the evaporites. Borehole control supports the interpretation that the $\mathrm{DZ}$ structures either do not extend into the Delaware Mountain Group or are very much reduced in amplitude. 


\subsubsection{Stratigraphic Correlation}

The seismic horizons need to be identified with particular levels in the stratigraphic section. At boreholes the stratigraphic section is known in feet; seismic horizons are known in seconds of acoustic travel time. Uphole velocity surveys are used to correlate the two.

Uphole velocity surveys are available for ERDA 9, WIPP 12 (above $2789 \mathrm{ft}$ ), WIPP 13, WIPP 18, and WIPP 34. Additional surveys in WIPP 11, WIPP 12 (below $2789 \mathrm{ft}$ ), WIPP 14, and WIPP 33 would aid the gravity interpretation. The new WIPP 12 survey would also help identify the mid-Castile seismic horizon.

The uppermost mapped seismic horizon is near the top of the Castile Formation. Boreholes WIPP 18 and WIPP 34 do not penetrate to this depth. WIPP 13 is within that area of the $\mathrm{DZ}$ where geologic structures are too complex to map with the seismic technique. The geologic markers at this borehole are indicated on the seismic sections (Figures 3-13 and 3-14).

The uphole velocity surveys of WIPP 12 and ERDA 9 were used to determine the acoustic two-way travel time to the top of the AIII member of the Castile Formation. Depths and travel times are indicated on Table 3-2. Posting these times onto seismic section 78GG20 indicates that the top of the Castile Formation is at or very near the uppermost seismic horizon.

Table 3-2. Stratigraphic Identification of Uppermost Seismic Horizon

\begin{tabular}{lcc} 
& $\begin{array}{c}\text { ERDA 9 } \\
\text { (ft) }\end{array}$ & $\begin{array}{c}\text { WIPP 12 } \\
\text { (ft) }\end{array}$ \\
\hline Kelly Bushing & 3420 & 3484 \\
Ground Level & 3409 & 3472 \\
$\begin{array}{l}\text { Depth to Anhydrite III } \\
\text { (from KB) }\end{array}$ & 2836 & 2741 \\
Time to 3300 datum & 0.2000 & - \\
(from survey) & & \\
Time to KB & - & 0.2114 \\
(from survey) & & \\
Adjusted two-way time to & 0.417 & 0.378 \\
3350 datum (@ 6000 ft/s) & & \\
\hline \hline
\end{tabular}

The deeper seismic horizons are only tentatively correlated with the stratigraphic section as indicated in Table 3-3.

\section{Table 3-3. Tentative Stratigraphic Identification of Lower Three Seismic}

Horizons

\begin{tabular}{clccc}
$\begin{array}{c}\text { Seismic } \\
\text { Horizon }\end{array}$ & $\begin{array}{c}\text { Stratigraphic } \\
\text { Identity }\end{array}$ & $\begin{array}{c}\text { Depth at } \\
\text { Site Center } \\
(\text { GCR Fig. 3.3-2) } \\
(\mathrm{ft})\end{array}$ & $\begin{array}{c}\text { Seismic Time } \\
\text { at Site Center } \\
(3350-\mathrm{ft} \text { datum }) \\
(\mathrm{s})\end{array}$ & $\begin{array}{c}\text { Interval } \\
\text { Velocity } \\
(\mathrm{ft} / \mathrm{s})\end{array}$ \\
\hline 1 & T/Anhydrite III & 2825 & 0.417 & \\
2 & Anhydrite II & 3450 & 0.505 & 14200 \\
3 & T/Cherry Canyon & 5100 & 0.775 & 12200 \\
4 & T/Bone Spring & 8000 & 1.255 & 12100 \\
\hline \hline
\end{tabular}




\subsubsection{Velocity Control}

The seismic interpretation resulted in a set of time-structure and isochron maps. Converting these seismic maps into geologic depth-structure and isopach maps requires a known (or assumed) velocity structure.

The velocity structure at the WIPP site is known directly through uphole velocity surveys and is indirectly indicated by the gravity field (see Sec 3.3). Both data indicate large lateral velocity variations within the stratigraphic layers.

The uphole velocity surveys measured the acoustic travel time between a source at the surface and receivers at known depths in the boreholes. The ERDA 9, WIPP 12, and WIPP 18 surveys were conducted by Seismic Reference Service, Inc. by using explosives in shallow (about 100-ft) shotholes. The WIPP 13 and WIPP 34 surveys were conducted by the Seismograph Service Corp. through the use of mechanical vibrators on the surface of the ground.

It is difficult to compare the source-to-receiver travel times between these different surveys because the field parameters (seismic wavelets, near-surface velocity variations, depths of measurements) differ. However, the interval velocities are found by dividing the depth increments by the corresponding increments of travel time; these interval velocities can then be compared directly.

In the following section on the interpretation of gravity, the interval velocities of the Dewey Lake, Rustler, and upper part of the Salado Formation measured at WIPP 13 are contrasted with those of WIPP 34. It is shown that the seismic velocity in the Rustler and Dewey Lake Formations at WIPP 13 is significantly less than at WIPP 34.

These variations of velocity apparently extend throughout the Salado Formation. Figure $3-16$ is a comparison of the interval velocities measured at ERDA 9, WIPP 12, and WIPP 13. The surveys differed in the number of measurements; ERDA 9 had the fewest. For this comparison, the interval velocities for WIPP 12 and WIPP 13 were recalculated at increments similar to those for ERDA 9.

The contrast in velocities for the Salado Formation between ERDA 9 and WIPP 12 accounts for $20 \mathrm{~ms}$ of seismic time structure. Similar effects result from the contrast for the Rustler and Dewey Lake Formations between WIPP 13 and ERDA 9 and
WIPP 12. The conclusion is that the lateral velocity variations preclude reliable conversion of the seismic time structure and isochron maps into geologic depth structure and isopach maps. The seismic maps reliably display seismic time structures, but it is uncertain whether the indicated time structures result from geologic depth variations or seismic velocity variations.

$\mathbf{0}$

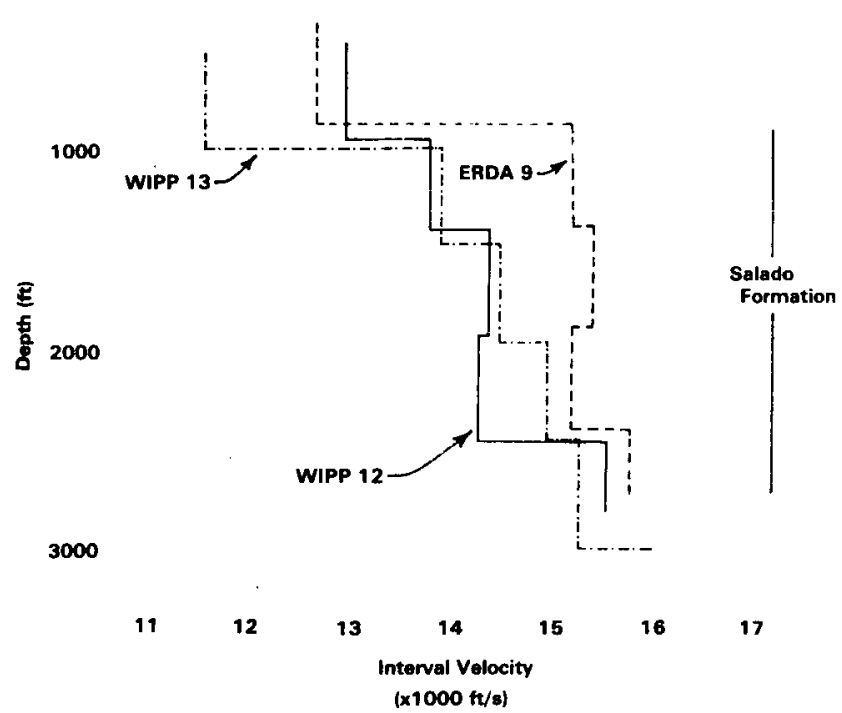

Figure 3-16. Comparison of Interval Velocities Measured During Uphole Velocity Surveys - ERDA 9, WIPP 12, WIPP 13

In petroleum exploration, seismic maps are almost always converted to geologic depth maps to determine the extent and closure of prospective structures. If no other information is available, a standard velocity is used in these cases to make the conversion. For the WIPP site evaluation, variations in lateral velocity may be as significant as the geologic depth structure. Because there is not enough information to separate the two effects and because both may be significant, the seismic interpretation is left in the form of seismic time structure and isochron maps. 
The broad open folds may be caused either by geologic depth structures or by lateral velocity variations. Their interpretation is ambiguous. However, the subtle fault indications ( 5 to $20 \mathrm{~ms}$ ) discussed in Sec 3.2.2 cannot be attributed to lateral velocity variations. This follows from the field and data processing parameters used to prepare the record sections. Recall that the survey used a 1650-440-0-440-1650 splitspread configuration with receivers spaced at $110-\mathrm{ft}$ intervals. This means that receivers were located at distances of 440 to $1650 \mathrm{ft}$ on either side of the shotpoint (24 receivers). For each sequential shot the entire assemblage was advanced $110 \mathrm{ft}$ along the line. (Physically one new receiver is added to one end, one is removed from the other end, the vibrators advance $110 \mathrm{ft}$, and receiver outputs are assigned new identification numbers.) During 12 -fold CDP data processing, the receiver outputs are gathered into groups of shot/receiver pairs where each pair in the group is symmetrically distributed with respect to the common-depth-point (CDP) in the middle. Each gather is added or stacked into a single trace in a method that emphasizes the best velocity for the reflections. Details of CDP shooting are described by Waters (1978). A single trace on the processed seismic section is comprised of energy traveling along 12 different paths distributed over $1650 \mathrm{ft}$ of the line. An abrupt change in the velocity of the overlying rock will gradationally affect $30(1650 / 110 \times 2)$ traces. However, small faults affect only a few adjacent traces. The resolving power of seismic reflection data is much better when considering small offsets between adjacent traces than when measuring total depth to geologic strata.

\subsection{Gravity}

The subsurface geologic structures at the WIPP site are known primarily through boreholes and seismic sections. These data indicate broad open folds over most of the site; a northeast-trending fault in the southeast corner of Zone IV; an east-trending faulted syncline (possibly a graben) in Sec 29, 30 of R31E, T22S; an area of complex structure in Sec 1, 2 of R30E, $\mathrm{T} 23 \mathrm{~S}$, and an area of complex structure in the northern part of the site (the DZ). Most of the deformation is restricted to the Castile Formation and involves redistribution of the massive anhydrite and halite members of this formation.

The density stratification of the Castile Formation is particularly striking. Figure $3-17$ is a copy of the compensated neutron density log of the Castile Formation in borehole AEC 8. The three massive anhydrite members with a density $\sim 2.95 \mathrm{~g} / \mathrm{c}^{3}$ are separated by halite members with a density $\sim 2.1 \mathrm{~g} / \mathrm{c}^{3}$.

The strong density contrast between the massive anhydrite and halite members and the localization of deformations to the Castile Formation suggested use of the gravity technique to investigate the structures. A survey was planned, and the gravity effect of some postulated structures was modeled to assist in selecting the field parameters. The modeled gravity anomalies were generally small (a few tenths of a milligal) and had double half-widths $\sim 2 \mathrm{~km}$. The WIPP survey was originally planned to resolve these anomalies.

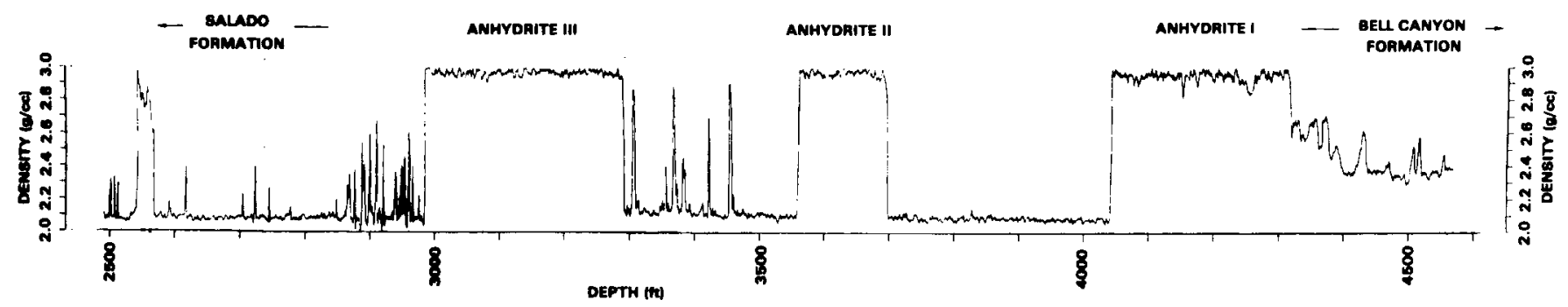

Figure 3-17. Compensated Densilog, Castile Formation, Borehole AEC 8 
SNLA had purchased a petroleum exploration regional gravity survey of the northern Delaware Basin before conducting the WIPP survey. (These data are proprietary and cannot be released.) This survey provides control for the regional gradient at the WIPP site and indications of an anomalous gravity field in the area of the DZ.

The WIPP gravity survey covered all of $\operatorname{Sec} 8,9$, $16,17,20,21,28,29$ and the southern third of Sec 4 and 5 of R31E, T22S. Stations or observations were spaced at 1/18-mi intervals along north-south lines 1/6 mi apart. Figure 3-18 shows the area of the survey and a net of reconnaissance profiles in the vicinity of borehole WIPP 33 .

The gravity field over the WIPP site is dominated by a strong regional gradient associated with the Delaware Basin and by a broad, east-trending, positive 1-mgal anomaly that peaks near the line between Sec 20,21 , and 17, 16. This positive anomaly was indicated by the proprietary regional gravity survey. It coincides with a topographic ridge (Figure 3-18) and with a seismic time-structure anticline in the Delaware Mountain Group (Figure 3-8). The correlation is such that $0.05 \mathrm{~s}$ of seismic two-way time structure corresponds to a 1-mgal gravity anomaly. Both the broad seismic time structure and the associated gravity anomaly could be due to geologic depth structures and a normal density increase with stratigraphic depth of about $0.22 \mathrm{~g} / \mathrm{c}^{3}$. However, borehole depths indicate deep structure that is discordant with this interpretation. An alternate interpretation is that the broad seismic time structure is a velocity effect resulting from lateral velocity variations within the overlying strata. The higher velocity material overlying the seismic pullup should have higher density that, in turn, would cause the positive gravity anomaly. Lateral velocity variations sufficient to cause such seismic effects are indicated by comparison of uphole velocity surveys through the Ochoan Series.

The WIPP gravity data were reduced by subtracting both a linear regional trend and a simple secondorder polynomial surface approximating the broad 1-mgal anomaly. Neither of these regional fields is rigorously controlled by geologic data; thus the residual map should be regarded as having undetermined first- and second-order trends. The elevation correction density of $2.3 \mathrm{~g} / \mathrm{c}^{3}$ was selected from borehole densilogs and inspection of gravity profiles over the topographic hill in the southeast corner of Sec 28.
Figure 3-19 is the resulting simple Bouguer gravity contour map.

The features on Figure 3-19 differ significantly from those anticipated during planning of the survey. The anomalies are much too sharp (shorter double half-width) to originate within the Castile Formation. They extend into areas that are indicated by the seismic profiles as undeformed.

The negative gravity anomalies were established by drilling to originate from lateral density variations within relatively flat strata. A detailed survey was conducted over a topographic depression that may be an alluvial doline centered on one of the negative gravity anomalies. The area of this detailed survey is indicated on Figure 3-19 and the resulting simple Bouguer gravity map is shown on Figure 3-20. The data for this detailed map were reduced with the same elevation correction density and regional trend as used for the WIPP survey map (Figure 3-18).

Figure $3-21$ is a profile across the anomaly along the line indicated on Figure 3-20. The anomaly at this location is $\sim 0.4 \mathrm{mgal}$ and has a double half-width of $500 \mathrm{ft}$. If a two-dimensional structure is assumed, the top to the causative density structure should be at or above $250 \mathrm{ft}$ (Nettleton, 1976, p 192), and the minimum missing mass was calculated as 470 tons per linear foot along the anomaly (method described in Nettleton, 1976, p 212).

Also shown on Figure 3-21 are the family of horizontal cylinders of varying densities and radii that each causes the modeled gravity anomaly. They show only the approximate scale of possible density structures and are not intended to indicate an interpretation.

Borehole WIPP 14 was drilled at the location indicated on Figure 3-20. The hole encountered normal depths to the stratigraphic horizons, but the measured densities in both the Dewey Lake and Rustler Formations were less than at nearby WIPP 34 . Part of the decreased density could be caused by conversion of anhydrite to gypsum.

The negative gravity anomaly at WIPP 14 extends generally west-northwest across Sec 9 and 8. Seismic line $\mathrm{X} 2$ runs north-south through the site center and transects the gravity anomaly near shotpoint 90 . The shallow seismic events near the Rustler Formation exhibit a pronounced depression in the area of the gravity anomaly. Both the seismic time structure and the gravity anomaly can result from lateral variations in density and velocity. 


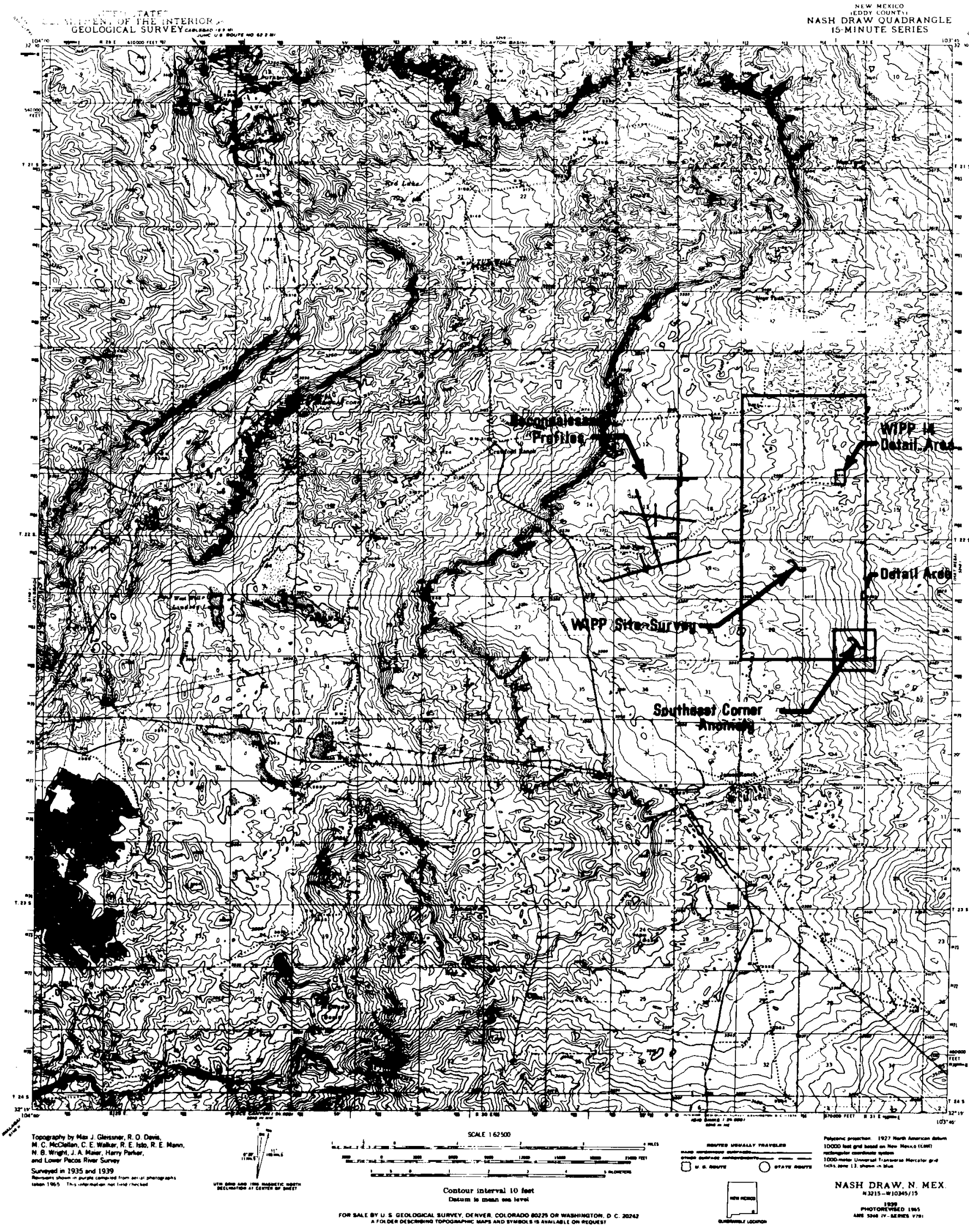

Figure 3-18. WIPP Gravity Survey, Detailed Areas, and Reconnaissance Profiles 


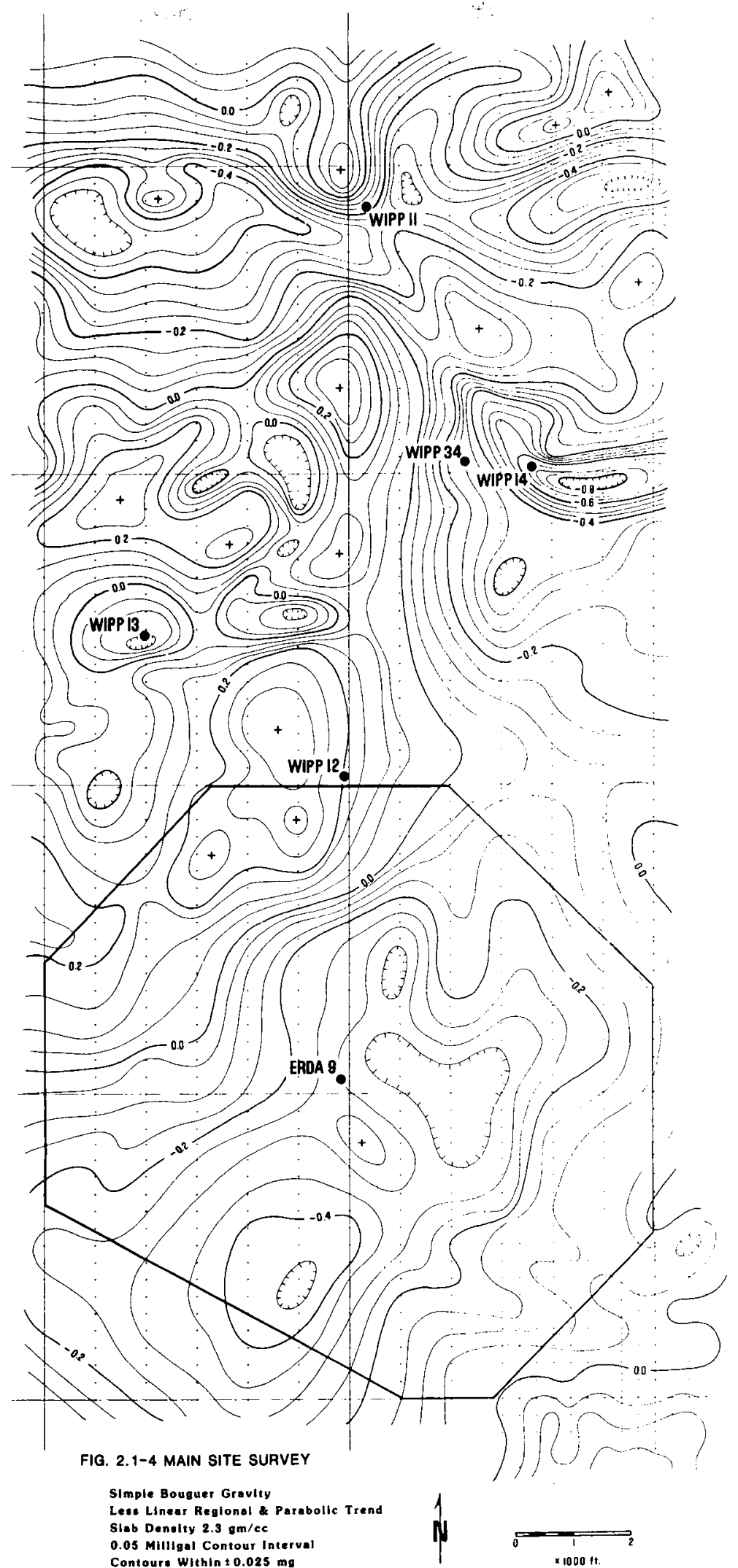

Figure 3-19. WIPP Gravity Survey, Simple Bouguer Gravity Map 


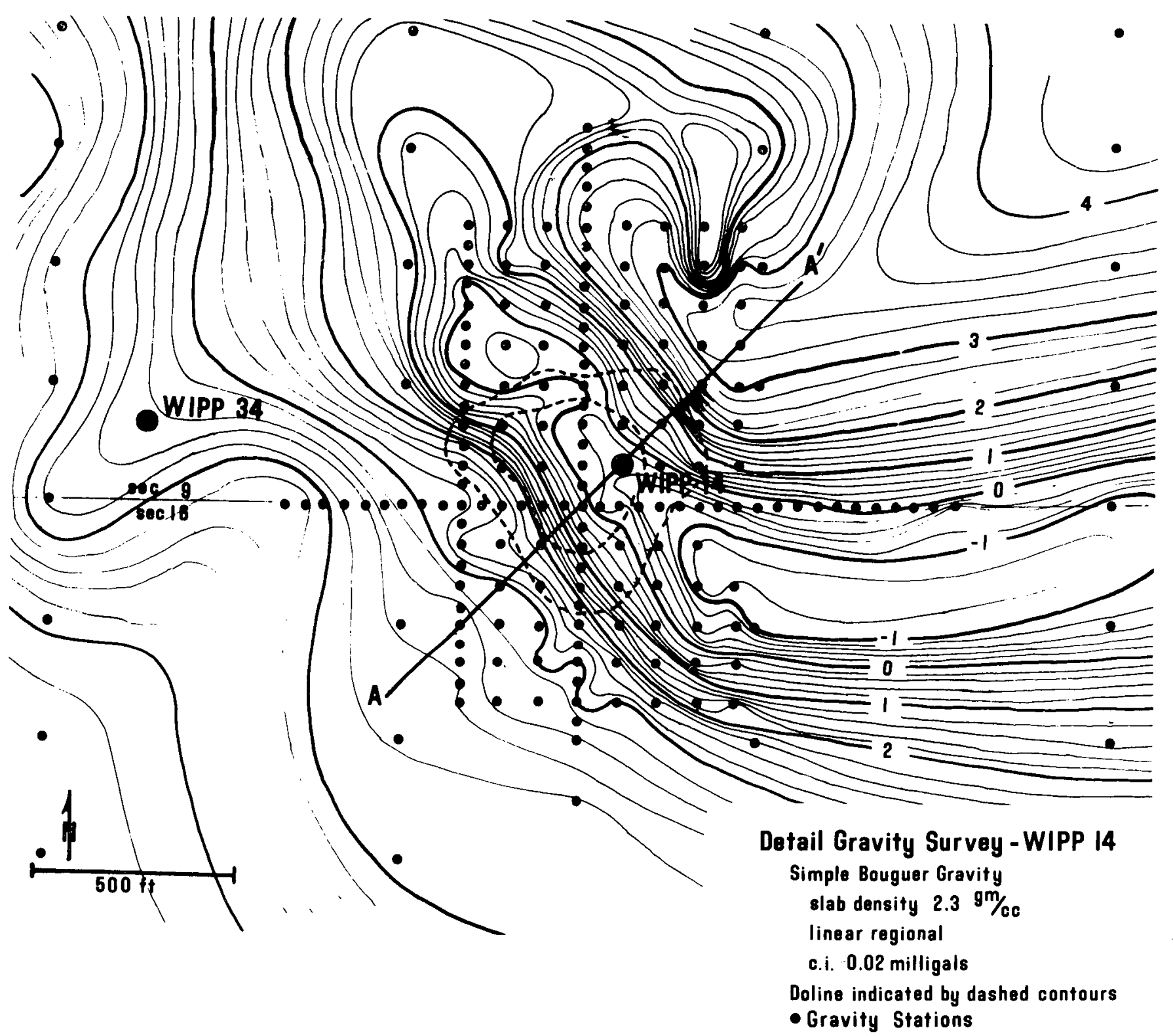

Figure 3-20. WIPP Gravity Survey, Simple Bouguer Gravity Map in Vicinity of Borehole WIPP 14 


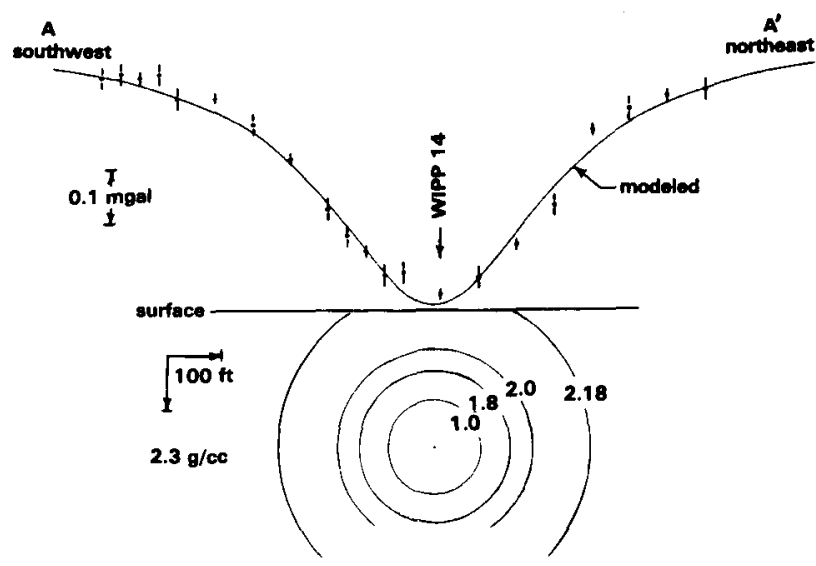

Figure 3-21. Profile Across the Negative Gravity Anomaly at Borehole WIPP 14

Figure 3-22 is a copy of seismic line $\mathrm{X} 2$ between shotpoints 58 and 105 along with seismic two-way times for borehole WIPP 11 (Table 3-4). WIPP 11 lacks the uphole velocity survey needed to rigorously convert horizon depths to seismic times. An approximate tie was made with measured velocities from WIPP 34 for rocks above the Salado Formation and from WIPP 13 for rocks below the Rustler Formation. This combination was used because WIPP 13 lies in a shallow-origin negative gravity anomaly; both WIPP 11 and WIPP 34 are in a normal gravity field. Velocities for the deeper horizons are from WIPP 13 because this is the closest borehole with measured velocities in both the Salado and Castile Formations.

Gravity survey line G (Figure 3-23) runs northsouth through the site center coincident with seismic line 77X2. The anomaly is identified in Figure 3-23, removed from the indicated broader trend, and plotted in Figure 3-22 on the same horizontal scale as the seismic section.

The seismically indicated syncline extends between shotpoints 80 and 97 , has a maximum amplitude of $0.035 \mathrm{~s}$, and is generally at the level of the Rustler Formation. The gravity anomaly at this location has an amplitude of $-0.55 \mathrm{mgal}$ and a double half-width of $1400 \mathrm{ft}$. The top of the density structure causing this anomaly should be no deeper than $700 \mathrm{ft}$.

If the seismically indicated syncline is a structural feature with no associated lateral velocity variations, it would have $\sim 135 \mathrm{ft}$ of closure $(0.035 \mathrm{~s}$ two-way time at $7734 \mathrm{ft} / \mathrm{s}$ ).
If the seismically indicated syncline is caused by lateral velocity variations in rocks above the Rustler Formation, the necessary velocity contrast is 7734 to $6420 \mathrm{ft} / \mathrm{s}$.

$662 \mathrm{ft}$ at $6420 \mathrm{ft} / \mathrm{s}=0.206 \mathrm{~s}$ two-way time

$662 \mathrm{ft}$ at $7734 \mathrm{ft} / \mathrm{s}=\underline{0.071} \mathrm{~s}$ two-way time

$$
\Delta=\overline{0.035}
$$

The high velocity $(7734 \mathrm{ft} / \mathrm{s})$ was measured at WIPP 34 . The low velocity $(6420 \mathrm{ft} / \mathrm{s})$ compares reasonably with the $6549 \mathrm{ft} / \mathrm{s}$ measured at WIPP 13.

Table 3-4 shows the interval velocities measured at WIPP 13 and WIPP 34, along with the seismic twoway times calculated for WIPP 11. Figure 3-24 compares the interval velocities calculated from the WIPP 13 and WIPP 34 surveys. The lateral velocity variations are consistent with the observation that WIPP 13 lies in a negative gravity anomaly.

The empirical Nafe and Drake curve (Nettleton, 1976, p 252) relates rock densities to velocities. The Nafe and Drake relation works well for common sedimentary rocks undergoing normal compaction and lithification. It is less reliable for evaporite rocks and should be applied with caution. For a velocity contrast of 7734 to $6420 \mathrm{ft} / \mathrm{s}$, the corresponding density contrast is near $-0.12 \mathrm{~g} / \mathrm{c}^{3}$. Figure $3-25$ is a model with this density contrast and a maximum thickness of $200 \mathrm{~m}(656 \mathrm{ft})$. The details needed to fit the model to the gravity observations are within the uncertainty in the control.

A first-order approximation of the seismic effect caused by the density structure is made with the following assumptions:

- The density contrast of $-0.12 \mathrm{~g} / \mathrm{c}^{3}$ is associated with a velocity contrast of 6420 to $7734 \mathrm{ft} / \mathrm{s}$.

- Vertical ray paths to the top of the Rustler Formation from coincident source/receivers at the surface.

This approximate seismic effect is shown in Figure 3-22.

A better seismic model would include the effects of ray bending at the sloping interface of the anomalous structure. Another, probably more important, correction is the effects of the actual vibrator/receiver array. Note that the total width of the modeled body is $550 \mathrm{~m}$ (1804 ft), and the survey used a 1650-440-0-4401650 split-spread configuration (processed as a 12 -fold CDP stack). Note also that the signal was muted so that shallow events are from only the inner receivers; deeper events are from all receivers. This probably explains why the shallow seismic structure is considerably reduced at the deeper horizons. 

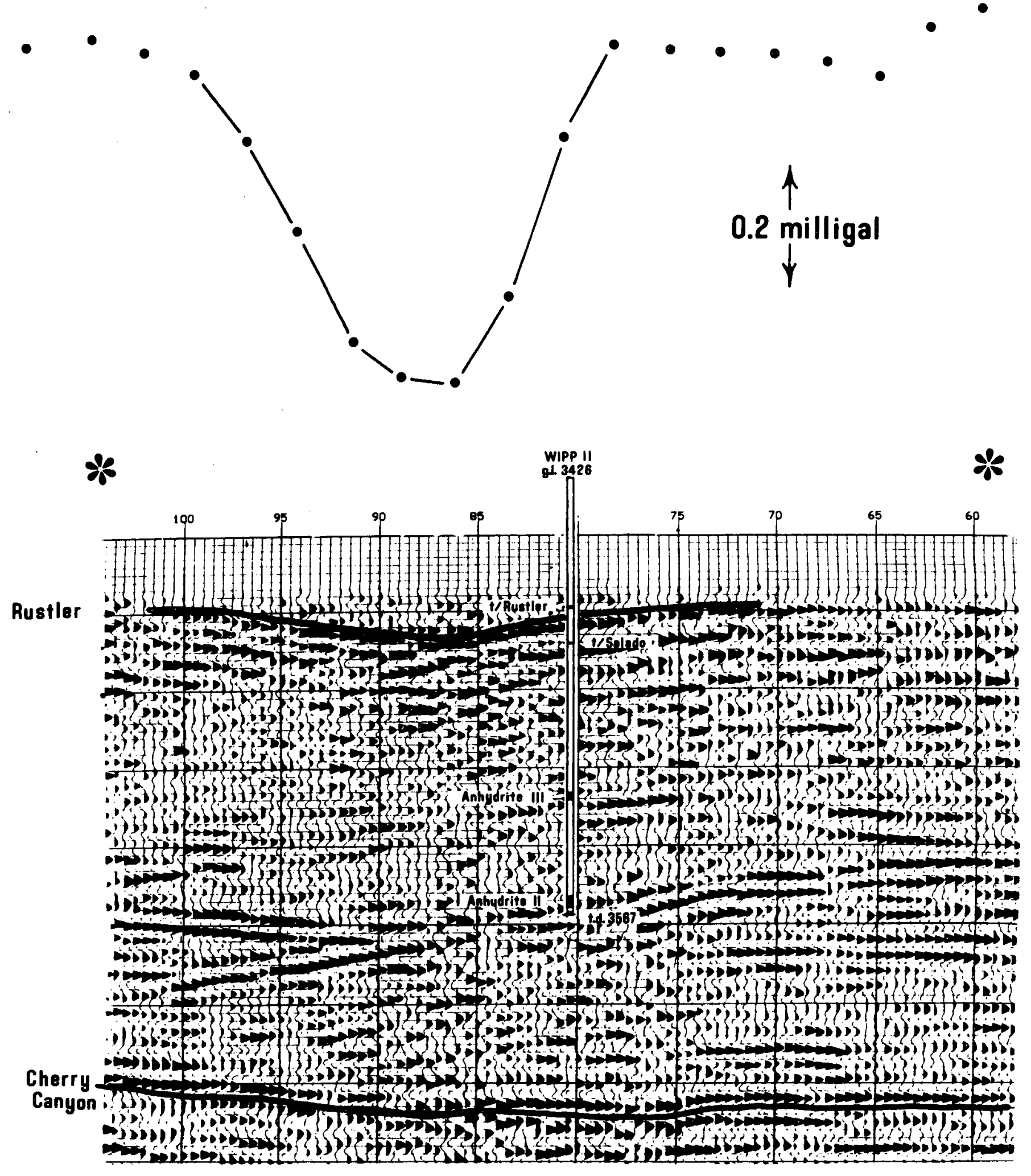

Figure 3-22. That Portion of Seismic Line 77X2 That Intersects the Negative Gravity Anomaly 
Table 3-4. Measured Velocities and Calculated WIPP 11 Depth-Time Tie

\begin{tabular}{|c|c|c|c|c|c|c|c|c|c|c|}
\hline \multirow[b]{2}{*}{$\begin{array}{l}\text { Horizon } \\
\text { Top }\end{array}$} & \multicolumn{3}{|c|}{$\begin{array}{c}\text { WIPP } 34 \\
(\mathrm{GL} 3433 \mathrm{ft})\end{array}$} & \multicolumn{3}{|c|}{$\begin{array}{c}\text { WIPP } 13 \\
(\mathrm{GL} 3405 \mathrm{ft})\end{array}$} & \multicolumn{4}{|c|}{$\begin{array}{c}\text { WIPP } 11 \\
(\mathrm{GL} 3426 \mathrm{ft})\end{array}$} \\
\hline & $\begin{array}{c}\text { depth } \\
\text { (ft) }\end{array}$ & $\begin{array}{c}\text { time } \\
(\mathrm{s})\end{array}$ & $\begin{array}{c}\text { velocity } \\
(\mathrm{ft} / \mathrm{s})\end{array}$ & $\begin{array}{c}\text { depth } \\
\text { (ft) }\end{array}$ & $\begin{array}{c}\text { time } \\
(\mathrm{s})\end{array}$ & $\begin{array}{c}\text { velocity } \\
(\mathrm{ft} / \mathrm{s})\end{array}$ & $\begin{array}{c}\text { depth } \\
\text { (ft) }\end{array}$ & $\begin{array}{c}\text { assumed } \\
\text { velocity } \\
(\mathrm{ft} / \mathrm{s})\end{array}$ & $\begin{array}{c}\text { time } \\
(s)\end{array}$ & $\begin{array}{r}\text { Seismic } 2 \text {-Way Time } \\
(\text { datum corrected to } \\
3200 \text { asl @ } 6000 \mathrm{ft} / \mathrm{s})\end{array}$ \\
\hline Surface & - & - & & - & - & & - & & - & -0.0753 \\
\hline Rustler Formation & 652 & 0.0843 & $\begin{array}{r}7734 \\
12570\end{array}$ & 518 & 0.0791 & $\begin{array}{r}6549 \\
11474\end{array}$ & 662 & $\begin{array}{r}7734 \\
12570\end{array}$ & 0.0856 & 0.0959 \\
\hline Salado Formation & 965 & 0.1092 & & 845 & 0.1076 & 14426 & 943 & 14426 & 0.1080 & 0.1407 \\
\hline Anhydrite III & & & & 2957 & 0.2540 & 19266 & 2330 & 19266 & 0.2041 & 0.3329 \\
\hline Halite II & & & & 3508 & 0.2826 & 15600 & 2411 & 15600 & 0.2083 & 0.3413 \\
\hline Anhydrite II & & & & 3625 & 0.2901 & 18958 & 3377 & 18958 & 0.2702 & 0.4651 \\
\hline Halite I & & & & 3716 & 0.2949 & 14921 & 3499 & 14921 & 0.2767 & 0.4781 \\
\hline Anhydrite I & & & & 3810 & 0.3012 & 16428 & 3549 & 16428 & 0.2800 & 0.4847 \\
\hline TD & & & & 3856 & 0.3040 & & 3567 & & 0.2811 & 0.4869 \\
\hline
\end{tabular}



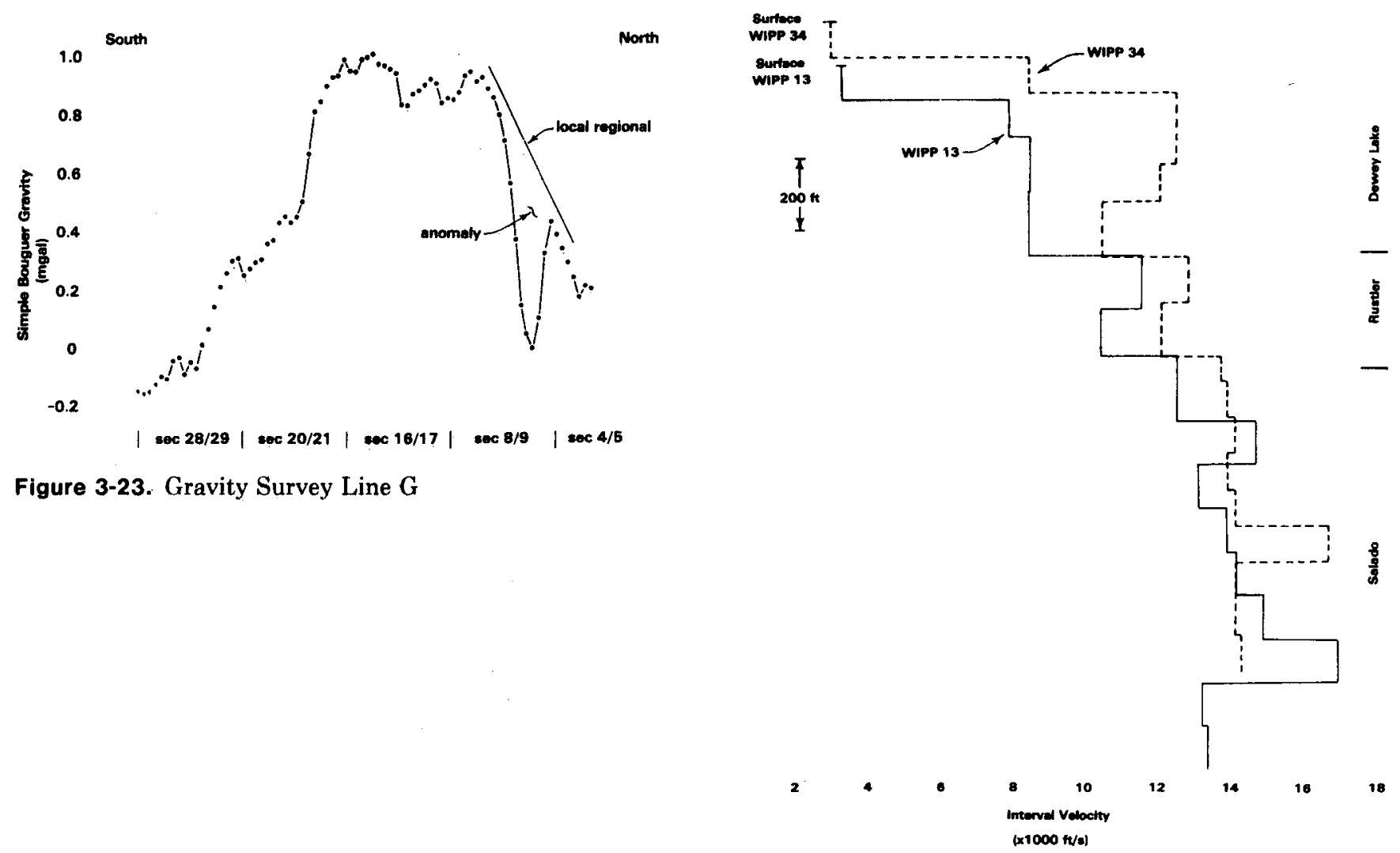

Figure 3-23. Gravity Survey Line G

Figure 3-24. Comparison of Interval Velocities Measured During Uphole Velocity Surveys - WIPP 13, WIPP 34

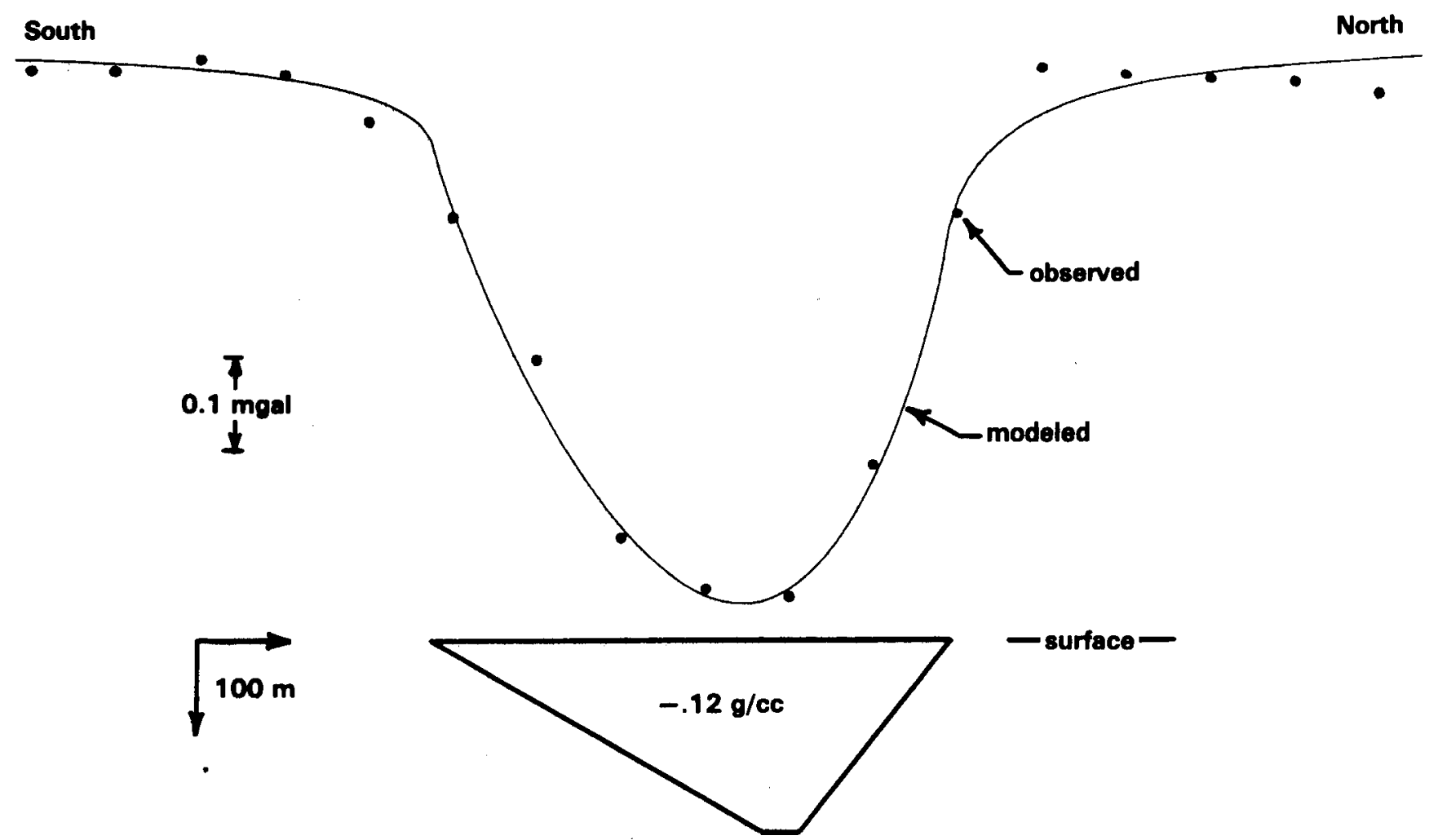

Figure 3-25. Modeled Gravity Anomaly - Survey Line G 
The seismic and gravity models show that the observed seismic and the negative gravity anomalies might originate from common lateral variations in velocity and density. The possibility of structural synclines or shallow stratigraphic channels cannot be ruled out, but appear very unlikely considering the existing borehole control, well logs, and core description.

The existence of the lateral variations in velocity and density is reasonably established by the gravity, seismic, and borehole data along with the uphole velocity surveys. A common consensus about their origin has not formed among the WIPP geologic investigators. L. Barrows believes they result from karst processes. The following discussion is of that interpretation by L. Barrows and is not necessarily agreed to by others and does not imply endorsement by Sandia National Laboratories.

The detailed gravity survey midway along the line between Sec 9 and 16 (later drilled by borehole WIPP 14) was centered on a closed topographic depression. This depression is $\sim 10 \mathrm{ft}$ deep and $700 \mathrm{ft}$ across, and it is one of many scattered through the Permian Basin. It is interpreted as an alluvial doline formed when loose surficial material washes through cracks in the Dewey Lake Formation into solution conduits in the Rustler Formation.

Borehole WIPP 33 was also drilled in a closed topographic depression and encountered normal depths to the stratigraphic horizons. This depression and borehole are in Sec 13 of T22S, R30E $\sim 1$ mi east of the edge of Nash Draw. A network of reconnaissance gravity profiles shows a negative anomaly of $0.6 \mathrm{mgal}$, with a double half-width of $900 \mathrm{ft}$ centered on this depression.

Borehole WIPP 33 encountered four cavities in the Forty-niner and Magenta Dolomite Members of the Rustler Formation. The alluvial dolines are reasonably related to cavernous zones, and the correlation of negative gravity anomalies with the dolines suggests that the lowered velocities and densities are also related to cavernous zones. The anomalies are too large to be due solely to the open space of the cavities. However, karst channels are persistent over long time periods, and it is reasonable to think that rock near karst channels would have altered petrophysical properties, perhaps by leaching, and that the anhydrite would be hydrated to gypsum. The negative gravity anomalies would then result from decreased rock densities near karst channels, primarily in the Rustler
Formation. This interpretation is consistent with those given by Arzi (1977) and by Omnes (1977) for microgravity surveys in other karst regions.

The interpretation of the negative gravity anomalies is understandably ambiguous. Spatial correlation between the negative gravity anomalies, the closed topographic depressions (here interpreted as alluvial dolines), and the cavernous zone in WIPP 33 may be coincidental. Not all of the topographic depressions have negative gravity anomalies, and not all negative gravity anomalies have closed topographic depressions. The seismic time-structure syncline on line $77 \mathrm{X} 2$ would be considered unreliable if it did not correlate with the negative gravity anomaly. Additional uphole velocity surveys (WIPP 11, WIPP 14, and WIPP 33) and borehole gravimeter surveys (WIPP 12, WIPP 13, WIPP 14, WIPP 33, and WIPP 34) are recommended.

Particularly important is the petrologic nature of the lateral variations within the Dewey Lake Formation. Inspection of the core from WIPP 14 and comparison with core of the Dewey Lake Formation in WIPP 19 did not reveal obvious differences. Further petrophysical analysis might provide additional insight into these lateral density variations.

Stratigraphic facies refers to aspects of the lithology that are attributable to lateral variations in the depositional environment. The possibility that the lateral density variations are caused by facies variations cannot be ruled out on the basis of gravity data alone. However, several observations suggest that this is extremely unlikely. First, the variations occur between two boreholes (WIPP 14 and WIPP 34) slightly more than $1000 \mathrm{ft}$ apart, and they affect most of both the Rustler and Dewey Lake Formations. These formations were deposited over tens of thousands of square miles in a broad depositional basin (Snider, 1966, Figure 34), and both holes are within this basin. C. L. Jones (1954, p 110) notes that while some halite members in the Rustler Formation thin reefward, the two dolomite members and several silt and sand layers form remarkably persistent stratigraphic markers. For the facies interpretation to be feasible, there would have to be a very localized depositional anomaly within the basin that persisted through the deposition of both formations. Considering the indications of halite dissolution within the Rustler Formation (Snyder, this volume, Sec 2.4.3; Ferrall and Gibbons, 1980; Bachman, 1980) the karst interpretation is much simpler. 
The gravity survey was unsuccessful in its original objective of delineating the DZ structures. Both the broad anomalies apparently originating from lateral velocity/density variations and the sharp negative anomalies, interpreted by $\mathrm{L}$. Barrows as resulting from karst processes, are sufficient to mask anomalies originating within DZ structures.

\subsection{Detailed Core Description}

The primary working tools of a structural geologist are observable folds, lineations, and their orientations. These structures often have a distinctive style, characterized by properties such as fold shape (isoclinal or open) and asymmetry or by observations of what mineral(s) or structure(s) defines a lineation. Such information often allows separation of the observed deformation into different events characterized by distinctive structural styles. The events may represent different episodes separated in space and/or time, or the separate events may signify discontinuous changes in mechanism during a continuum of one deformational episode. As these observations and divisions are made over an area, one may begin to construct an image of deformational events in time and space. Such an areal description has been done for the WIPP site and is reported here.

\subsubsection{Multiple Fold and Deformation Textures}

Several generations of folds and deformation are observed as follows (see Figures 3-26 through 3-29):

- Isoclinal folds with opposite sense of asymmetry, i.e., Z- vs S-type folds instead of younger folds. These isoclinal folds may represent a sedimentation or resedimentation accompanying a slumping event (Parea and Ricci-Lucchi, 1972; Ricci-Lucci, 1973).

- Open asymmetric folds related to a penetrative deformation accompanied by an extension jointing and vein system that parallels the axial plane of the open folds similar to a zoned crenulation cleavage of Gray (1977).

- Ptygmatic and often disrupted folding of isolated anhydrite laminae in halite.

- Dimensional halite fabric.

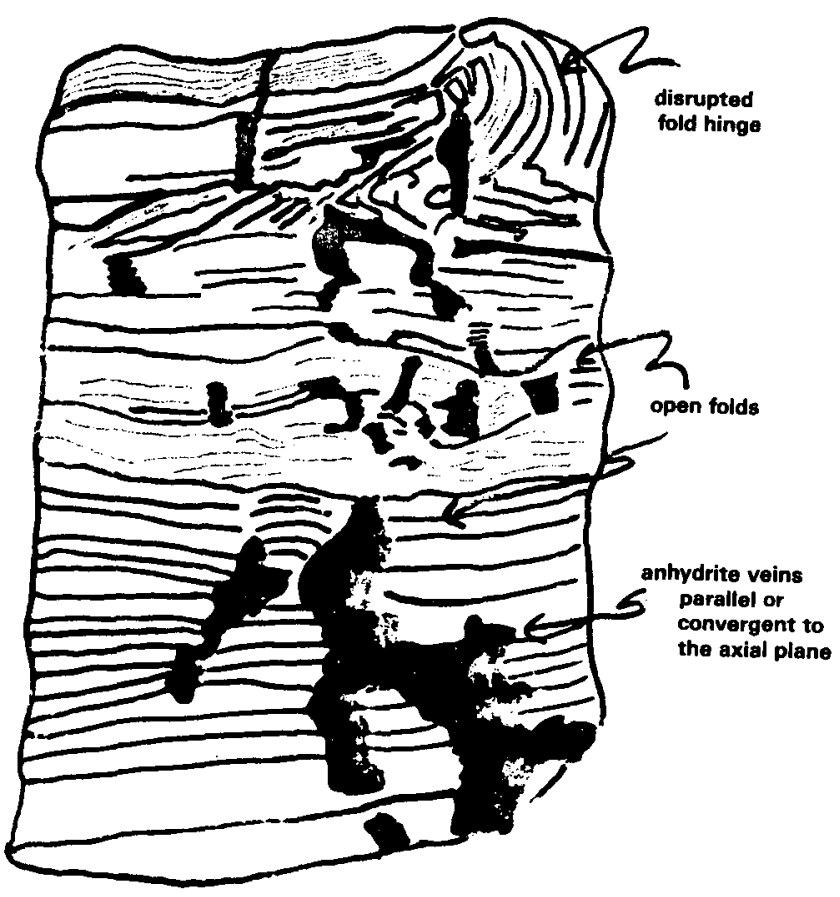

Figure 3-26. Deformation Styles in Laminated Carbonate Anhydrite Units of the Castile (WIPP 13, $3727 \mathrm{ft}$ )

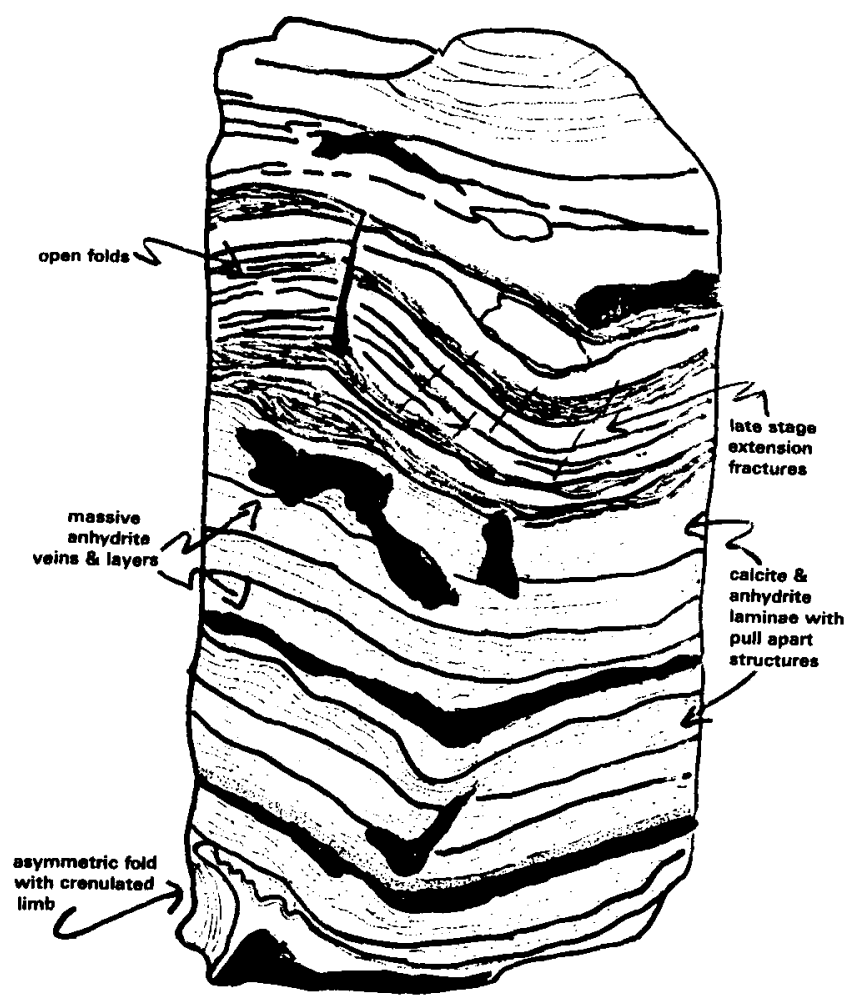

Figure 3-27. Deformation Styles in Laminated Carbonate Anhydrite Units of the Castile (WIPP 13, $3727 \mathrm{ft}$ ) 


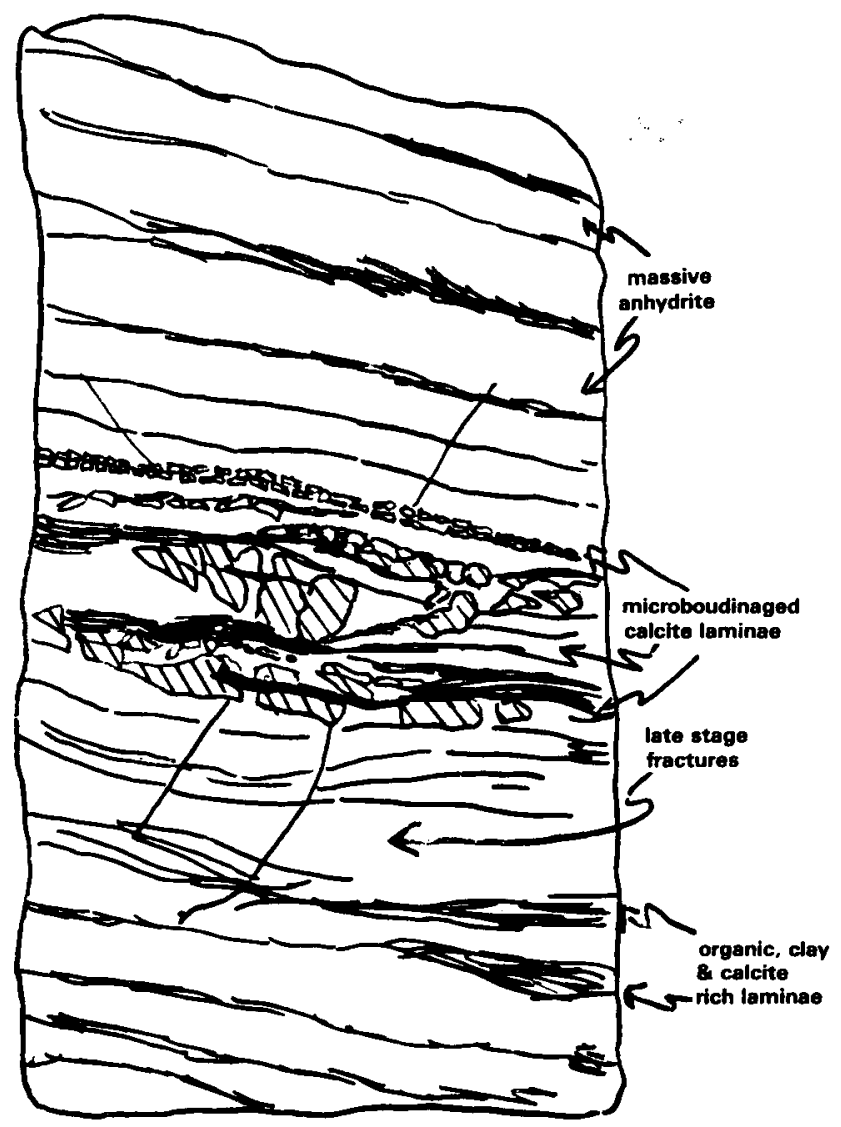

Figure 3-28. Deformation Styles in Laminated Carbonate Anhydrite Units of the Castile (WIPP 13, $3729 \mathrm{ft}$ )

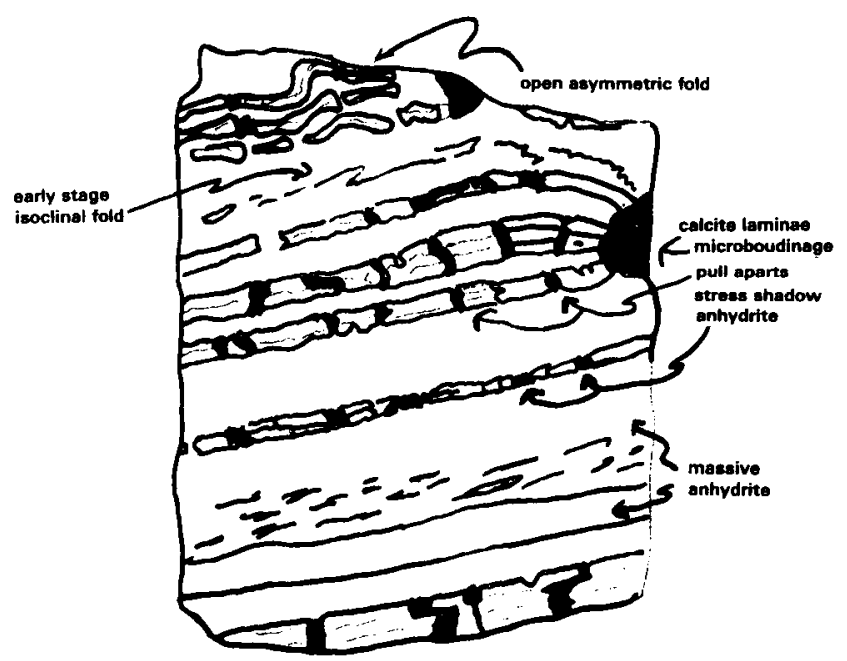

Figure 3-29. Deformation Styles in Laminated Carbonate Anhydrite Units of the Castile (WIPP 13, $3733 \mathrm{ft}$ )
The fold styles and opposite sense of asymmetry identify the early sedimentary or metasedimentary deformation relative to a later stage, possibly tectonic structures. The opposite sense of asymmetry and layer confinement of the sedimentary structures imply that these structures could not have formed during the tectonic deformation. The tectonic structures are characterized by asymmetric folds, necking, or pulling apart of competent calcite laminae and veining parallel to the axial plane of folds developed during this stage. Structures suggest the presence of a fluid accompanied by solution and redeposition during deformation. Such evidence is the axial plane veining, pressure solution in nodes of folds, and shadow zone halite in pull-apart structures. The extension fractures as described by Kirkland and Anderson (1970) and Anderson and Powers (1978) are not a purely fracture phenomenon, as attested by bounding organic-rich laminae extending part way across the pullapart structure. This structure developed in response to extension and associated pressure solution.

Other solution-related features accompanying deformation are exhibited at the 2733-ft level of ERDA 6 , a section described as a fault zone by Jones (1981). However, current reexamination indicates that this section is a major halite vein that encroached along the foliation planes of the Castile. This vein enlarged by dissolution of the country rock and incorporated clay-band residues that are relics of the Castile foliation.

\subsubsection{Petrographic Description: Deformation Mechanism}

\section{Introduction}

Microstructures are revealed through petrographic description, and clues for determining the deformation process come through such study. These important clues are often the destruction of preexisting grains and the formation of new grains related to the kinematic history of the rock. Observations like these allow an initial determination of relative ages for deformation events. Also, intergranular textures and internal textures of individual grains often reveal some information such as saturated grain boundaries or twinning, which helps to pinpoint which deformation mechanisms have occurred. 
Several distinct processes manifest deformation mechanisms in rocks:

- Grain reorientation

- Grain breakage

- Plastic deformation

- Dissolution - precipitation reactions

Each of these processes will characterize the deformation mechanism at different stresses, strain rates, and temperatures. To understand the deformation of the disturbed zone, we need to determine which mechanisms were active within the halite and anhydrite units.

\section{Experimental Studies}

Muller and Briegel (1978) and Muller et al (1981) investigated the rheological behavior and deformation of natural anhydrite. Generally, the strength of anhydrite was found to be between that of halite and finegrained limestones (see Figure 3-30). Intracrystalline glide and twinning were the major deformation mechanisms (Muller et al, 1981). The transition from workhardening to steady-state flow at low stresses correlates with the onset of dynamic recrystallization by grain-boundary migration. For geologically reasonable strain rates $\left(10^{-10} / \mathrm{s}\right.$ to $\left.10^{-14} / \mathrm{s}\right)$, the temperature threshold for drastic strength reduction in anhydrite is placed between $180^{\circ} \mathrm{C}$ and $200^{\circ} \mathrm{C}$.

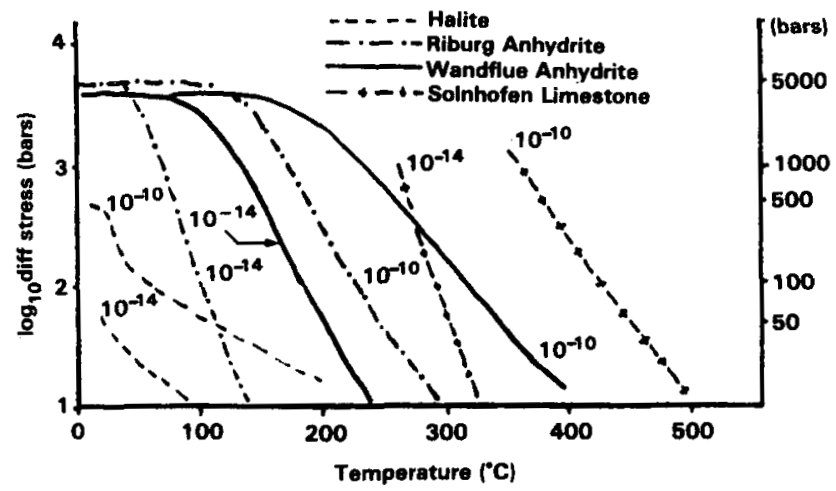

Figure 3-30. Synoptic Diagram of Log Stress vs Temperature Illustrates the Relative Strength at $10 \%$ Strain of Halite, Anhydrite, and Limestone Expected Under Geological Strain Rates

\section{Microscopic Textures}

In the experiment conducted by Muller et al (1981), the anhydrites that were deformed at room temperatures exhibited undulatory extinction. At higher temperatures, twinning became the dominant microstructural feature in weakly deformed anhydrites. As deformation increased, lattice reorientation occurred by shear twinning and twin boundary migration. Dynamic recrystallization is evident at higher temperatures in the region of steady-state flow. Sutured grain boundaries suggest that grain-boundary migration occurred instead of nucleation and growth or subgrain rotation.

\section{WIPP 13 Microscopic Textures}

Thin sections from WIPP 13 at depths of 3667.4, 3727.7 , and $3733.5 \mathrm{ft}$ were made for petrographic studies (Figures 3-31 and 3-32).

These samples exhibit microboudinage of calcite laminae (see Figure 3-32) as expected because of the relative strengths of calcite and anhydrite. However, the microboudinaged calcite laminae do not form perfect jigsaw puzzles. Pull-apart boundaries are diffuse or embayed, suggesting some dissolution of the boundary.

Anhydrite occurs in the fine-grained matrix mosaic or as coarser grained neoblasts (new relative growth grains; see Figures 3-31 and 3-32). The neoblasts exhibit pressure shadow growth in the pull-aparts of the microboudinaged calcite laminae. The deeper specimens, $3727.7 \mathrm{ft}$ and $3733.5 \mathrm{ft}$, display nucleation of anyhydrite on the pull-apart surface and elongation of the anhydrite neoblasts. Some elongated neoblasts (see Figure 3-31) contain helicitic inclusion trains, suggesting synkinematic growth and rotation (Vernon, 1975). Such rotated neoblasts are similar to propellor chloritoids in the Alps (Zwart and Calon, 1977). Despite the suggestion of the synkinematic growth and rotation, the anhydrites lack twinning and undulatory extinction. 


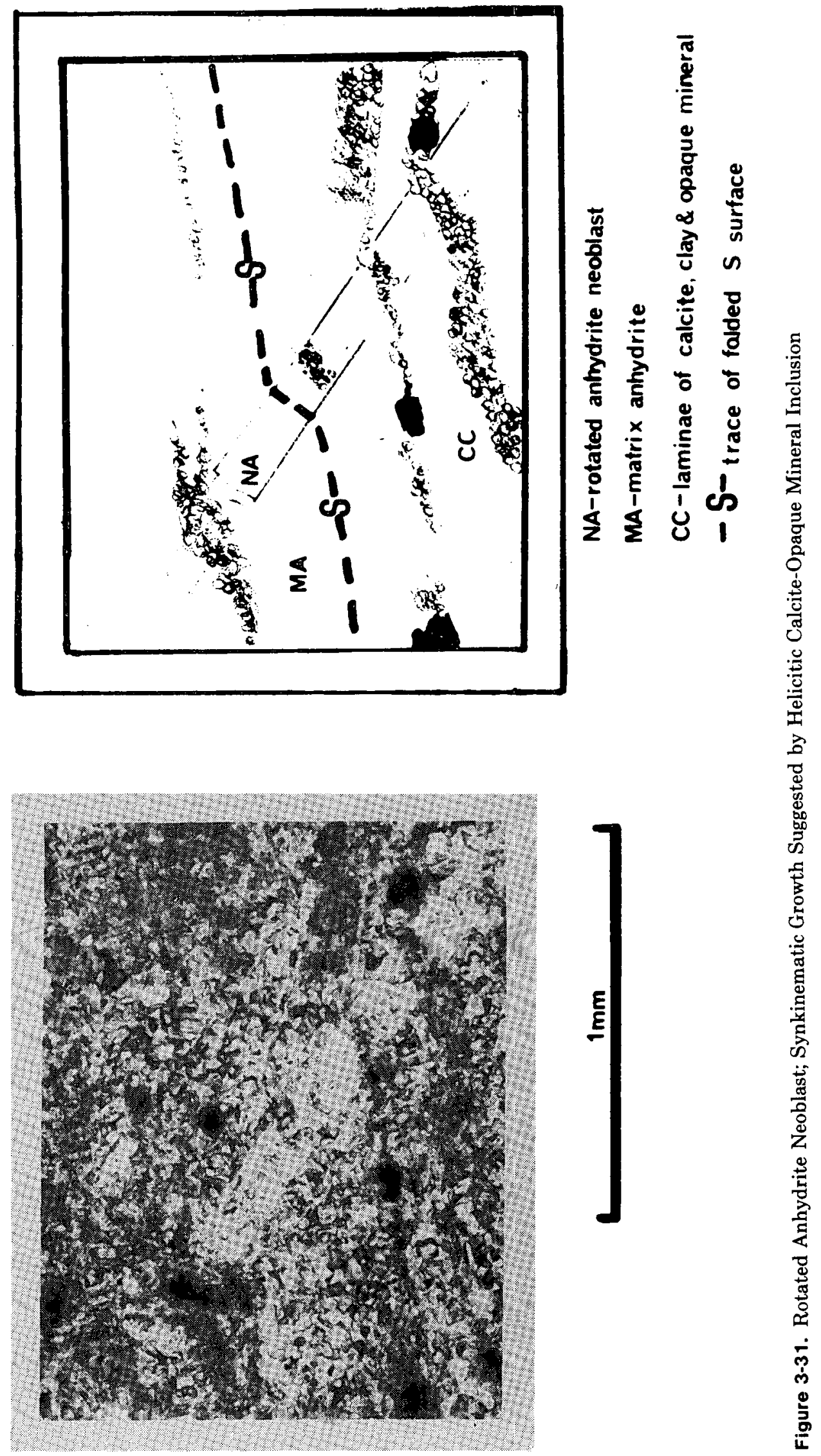




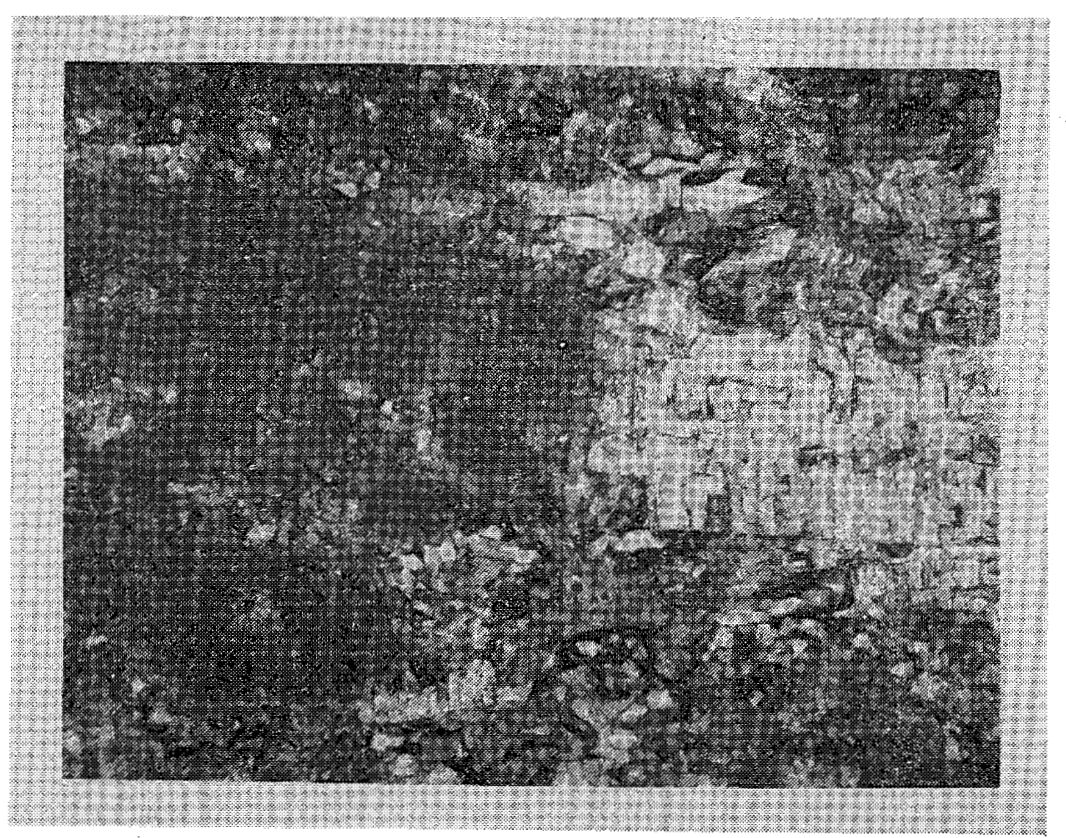

$1 \mathrm{~mm}$

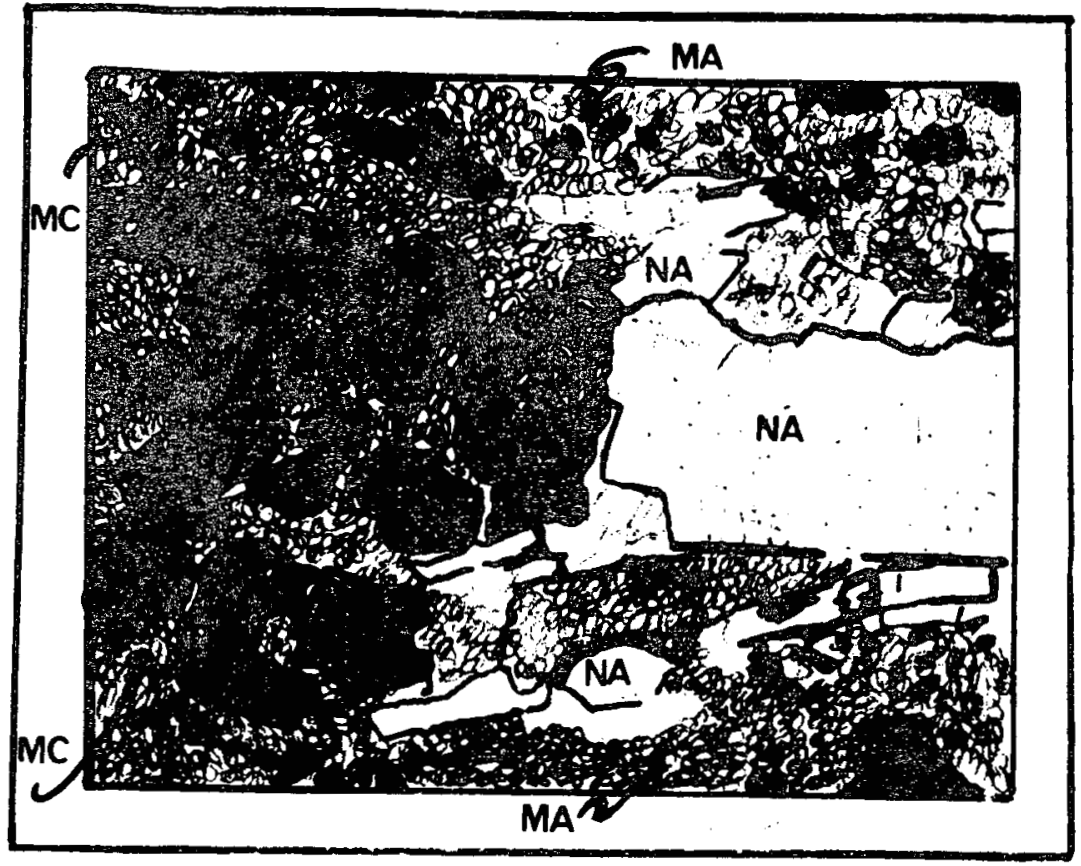

NA-neoblast anhydrite

MA-matrix anhydrite \& clay

MC-microboudinaged calcite laminae

Figure 3-32. Pressure Shadow Growth of Anhydrite Neoblast; Microboudinage of Calcite Laminae 


\section{Hypotheses of Origin}

\subsection{Gravity Foundering}

At least some tectonic stress results from gravity acting on the earth's complex density structures. Such structures may be formed by processes other than structural deformation, such as thermal expansion, mineral phase changes, or initial deposition. In these cases the density structures can be primary sources of tectonic stress. The tectonic stress comes from the tendency of the materials to deform towards a state of minimum gravitational potential energy in which the denser material is on the bottom and the lighter is on the top. Even global plate tectonics probably results from the gravitational rise of hot low-density material at the ridges and from complementary sinking of cool higher-density material at the trenches (Jacoby, 1970). Concepts of gravitational tectonics are developed in the texts by DeJong and Scholten (1973) and Hans Ramberg (1981) and in articles by Artyushkov (1973), Barrows and Langer (1981), Dennison (1976), Milici (1975), Price (1971, 1973), and VanBemmelen (1976).

The density stratification of the Castile Formation is particularly striking. Figure 3-17 is the compensated neutron density log of the Castile Formation at borehole AEC 8 . The three massive anhydrite members with a density of $\sim 2.95 \mathrm{~g} / \mathrm{c}^{3}$ are separated by lighter halite members. This density structure is gravitationally unstable. There are tendencies inherent in the density structure for the massive anhydrite to sink below the less dense halite, and the less dense halite to rise above the anhydrite. Whether the deformation occurs, and its rate, depends on the physical properties of the actual rocks. Ramberg (1981) has extensively investigated systems similar to the density stratification in the northern Delaware Basin. Part of this work involves the mechanical analysis of the gravitational deformation of a sequence of initially horizontal, viscous layers of varying densities, thicknesses, and viscosities.
In the Appendix to this report, these analytic techniques are applied to the regional density stratification of the WIPP site. The analysis is consistent with high-amplitude closely spaced folds in the Castile Formation; low-amplitude broad folds at the top of the Salado Formation; and little or no deformation at the ground surface, the repository horizon, and in the Delaware Mountain Group. If effective viscosities are assumed that are typical of those used to model salt diapirs, $\left(10^{18} \mathrm{P}\right)$, the rate of deformation is $0.05 \mathrm{~cm} / \mathrm{yr}$.

Another part of Ramberg's work involves centrifuge modeling of gravitational deformations. Such models are significant to tectonic studies because if they are properly scaled they pass through a structural evolution identical to that of their geologic prototype. In the Appendix, the scaling ratios of centrifuge models or orogenic belts are redefined so that models represent gravitational foundering of massive anhydrite through less dense halite. The models provide an appreciation of the structural complexity resulting from the gravitational process. There is an inference that the required duration for development of the $\mathrm{DZ}$ is about $700000 \mathrm{yr}$.

The apparent stability of undeformed areas is less well understood. A possible explanation lies in the dependency of gravitational shear stress on the amplitude of existing deformations. As noted in the Appendix, the shear stress at the deforming interface between two gravitationally unstable layers is proportional to the amplitude of the deformation. No deformation would occur if the evaporites possess a finite yield strength that is higher than the gravitational stress inherent in naturally occurring lowamplitude structures. Secondary processes, such as external tectonic faulting, could produce initial structures whose gravitational tectonic stress is above this yield strength. The DZ deformation would then grow 
outward from this area. An indication of such initiating structures is the high on the top of Anhydrite I at WIPP 11.

An alternate interpretation for localization of complex structures within undeformed areas is suggested by the effect of water on evaporite rheology. Wenkert (1979) noted that the strain rate in Iranian salt glaciers was very much larger than predicted by previously investigated halite flow mechanisms. He attributed this to an interstitial solution of saltwater. D. Borns (Sec 3.4) suggested that low-temperature pressure solution facilitated by water may be a deformation mechanism in the DZ. Anomalously high water content may be supported by the brine pockets encountered in disturbed structures in the northern Delaware Basin. In this interpretation, the complex structures form in areas of anomalously high water content or anomalously distributed water because the water facilitates grain boundary pressure solution. The brine pockets form when intergranular water migrates into low stress regions in the developing structures.

The gravitational foundering mechanism is consistent with available observations. The mathematical analysis and centrifuge models presented in the Appendix suggest that $\mathrm{DZ}$ structures are the expected consequence of existing density stratification, along with reasonable estimates of evaporite viscosity.

\subsection{Dissolution Mechanisms}

Dissolution of salt in the Castile Formation has been proposed as the origin of the structures near the site and in the northern Delaware Basin. It has been proposed in two somewhat different forms: (1) dissolution near the top of the evaporite section may have caused collapse and fill, and the reduced local density permitted structural deformation to start (Anderson and Powers, 1978); (2) dissolution in the Castile (or perhaps lower Salado) removed halite and resulted in deformation of overlying and surrounding beds, as in the DZ (e.g., Anderson, 1981). Neither form of the mechanism recognizes a potential role for intergranular fluids in changing the mechanical behavior of the rock. The association of deformation and brine was made, but the various discussions (e.g., Chaturvedi, 1980 ) indicate that brine is considered to have been trapped by the structure without playing an active role in its deformation. We will discuss our present concept of the role of fluids in deformation in Sec 6.4.

Lambert (1983) has summarized the evidence for dissolution as the origin of various features around the northern Delaware Basin. In this discussion, we consider only features within the Delaware Basin that appear nominally similar to the DZ. We do not discuss single borehole anomalies in salt thickness nor various manifestations of dissolution such as "breccia pipes," karst mounds or domes, and the like. Of interest here are the $\mathrm{DZ}$, the deformation adjacent to the reef margin, structures of the Poker Lake field, and the structure southwest of the site at the James Ranch field. These features are amenable to some analyses of the role of dissolution.

How can we examine the effects of dissolution on such deformation? If near-surface dissolution has initiated deformation, the remains of collapse-and-fill structures should be prominent in the region of deformation. The Bilbrey Basin and San Simon Swale areas have fill of probable lower density sediments. (The differentiation between erosion and shallow dissolution is unimportant here.) This is consistent with the general statement of the hypothesis (Anderson and Powers, 1978). The DZ near the WIPP site has some dissolution indications of such shallow density changes, according to high-precision gravity data. However, as shown by the Rustler isopach (Figure $2-8$ ), the more general pattern of shallow dissolution is roughly north-south and exhibits very little correlation with the boundary of the DZ. Equivalent detail is not available for the James Ranch anticline and the Poker Lake structures.

Dissolution within the evaporite beds, particularly the Castile and lower Salado, is supposed to have a more direct effect on deformation by removing salt. Two effects, apart from deformation, are probable: the formation of dissolution residues and the net loss of sediment from the section. Recrystallized halite has been taken as prima facie evidence of dissolution (e.g., Anderson, 1981), but for the $\mathrm{DZ}$ there is no such unique relationship to the large deformation features. Likewise, the brine reservoirs in deformed evaporites have been associated with dissolution by Anderson (1981). He also invokes a connection in the past (and possibly in the future) with the underlying fluidbearing unit of the Delaware Mountain Group. We do not believe there is a major credible association between the Delaware Mountain Group, regional dissolution, and brine reservoirs, because of the chemistry (Lambert, 1978 and 1983) and the small volume of brines. 


\subsection{Gravity Slides}

Gravity tectonics is a highly scale-dependent concept. Large-scale phenomena such as lithospheric plate interactions can be attributed to gravitational processes. However, gravity tectonics in the restricted sense is the process where at crustal levels a regionally integrated tectonic system has lost potential gravitative energy during deformation (De Jong and Scholten, 1973). Such reduction of free potential energy can be accomplished either through vertical displacement (diapirism), or by gravity slides that are dominantly lateral displacements. Diapirism, or halokinesis, is discussed in the Appendix. Gravity slides are the focus of this section.

Two processes of gravity slides can be envisaged for the WIPP site deformation. One is the initiation of gravity slides by basin tilting. The other is slides produced by density contrasts within interfingering anhydrite-halite sequences at the reef margins. Problems with such processes are the relative timing of deformation and tilting, and the question whether the angle of tilting or the strength of density inversion is adequate to initiate deformation.

Another objection would be the lack of detachment or decollement surfaces for the gravity slides. However, a zone of low viscosity such as the halite layers in the Castile can facilitate mass movement rather than discrete surfaces (De Jong and Scholten, 1973). The problems of timing and adequate energy to initiate deformation are discussed individually below.

The important question rises whether deformation occurred coeval to or after basin tilting. Deformation is related by Kirkland and Anderson (1972) and Anderson and Powers (1978) to tilting because of the parallelism of fold hinges and strike of the basin during tilting. The timing of basin uplift and tilting is placed as follows by King (1948), Hayes (1964), and Anderson (1981), respectively:

- Minor uplift and exhumation in the early Cenozoic

- Earliest identifiable phase of uplift, probably in the Miocene to early Pliocene

- Main phase of uplift, in the late Pliocene to early Pleistocene

However, Jones (1981) places the ERDA 6 anticline as pre-Ogallala Formation and therefore as pre-Miocene. Thus, some of the site deformation occurred before the suggested main stage of tilting. The interrelationship of basin flexure and deformation may be critical, but it is not clear and possibly could be only a covariance.

Regarding the question of adequate strength, Wenkert (1979) calculated the shear stresses at the base of salt glaciers. Under the conditions of temperature, strain rate, and calculated stress for the glaciers under consideration, Wenkert concluded that deformation did not occur through either of the mechanisms of Nabarro-Herring creep or dislocation climb. However, he proposed a deformation mechanism of ion diffusion through an interstitial saltwater solution from intercrystalline boundaries of high stress to those of low stress. This process is equivalent to pressure-solution mechanisms discussed elsewhere in this report. Similar calculations can be made for the WIPP site and result in a shear stress an order of magnitude higher than Wenkert's calculation for the salt glacier $\left(2 \times 10^{5} \mathrm{~Pa}\right.$ compared to $\left.3 \times 10^{4} \mathrm{~Pa}\right)$. Still, it is not clear, based on experimental and theoretical conditions, whether the slope of the Delaware Basin is adequate to initiate salt movement through the mechanisms of creep and/or dislocation climb. Again, the presence of an intergranular fluid may lower the thresholds of deformation. Much work remains to be done on halite and anhydrite petrofabrics from the WIPP site to determine the active deformation mechanisms.

In summary, the relative timing of deformation and basin tilting is critically important in ascertaining whether gravity sliding was or is a mechanism in site deformation. Some field evidence in the case of the ERDA 6 anticline suggests that deformation occurred before the main stage of basin tilting. However, we must be wary not to preclude earlier basin tilting. Such tilting, although minor, could have been related to the Nevada-Sevier and Laramide orogenies that affected the Cordillera during the Mesozoic. It is harder to evaluate the potential for gravity slides that are related to the density contrast and inherent metastability at the reef margins. Again, under the low temperatures of the Delaware Basin, the stresses produced by such density contrasts may not be adequate to initiate deformation without weakening by intergranular fluids, or unless deformation occurred in the Permian before consolidation. Kirkland and Anderson (1970) argue that several meters of laminated 
anhydrite and carbonate involved in the folding contain $10000 \mathrm{yr}$ of varves. Their argument continues in that it is unlikely that the sediments remained unconsolidated over such periods of time; therefore, deformation occurred after consolidation. Also, the syndepositional folding described in this report is layer-bound; later structures involve multiple layers. Hence, most of the deformation is inferred as younger than the Permian deposition of units in the basin. Reef margin gravity slides cannot explain the deformation that occurs in the center of the basin. In conclusion, lateral displacement gravity tectonics or gravity slides may be attractive processes for the site deformation, but there are serious mechanistic and timing problems.

\subsection{Gypsum Dehydration}

Kirkland and Anderson (1970) discuss the historical development of the gypsum dehydration hypothesis. From the experimental standpoint, Heard and Rubey (1966) proposed that deformation in evaporite sequences and movement of thrust sheets with basal zones of evaporite were facilitated by the dehydration of gypsum.

$$
\underset{\text { gypsum }}{\mathrm{Ca} \mathrm{SO}_{4} \cdot 2 \mathrm{H}_{2} \mathrm{O}}=\underset{\text { anhydrite }}{\mathrm{Ca} \mathrm{SO}_{4}}+\underset{\text { water }}{2 \mathrm{H}_{2} \mathrm{O}}
$$

This hydraulic weakening was suggested by an observed tenfold decrease in strength during Heard and Rubey's experiments. The process envisaged is the increase in fluid pressure within relatively impermeable rock sequences caused by thermal decomposition of hydrous minerals such as gypsum. For gypsum in the experimental runs, this decomposition and associated strength decrease occurred over the temperature range of $100^{\circ} \mathrm{C}$ to $150^{\circ} \mathrm{C}$. In the Gulf Coast, such temperature thresholds would be encountered at depths of 2500 to $6000 \mathrm{ft}$. However, Heard and Rubey have not considered the effects of lowered $\mathrm{H}_{2} \mathrm{O}$ activity in associated brines. Such lowered activity as expected in nature would lower the equilibrium temperature of reaction, $\mathrm{Eq}(1)$.

In the case of the deformed evaporites of the WIPP site, the dehydration hypothesis would require that areas within the lower evaporites such as the Cowden and the anhydrites of the Castile contain heterogeneous pockets of gypsum. Such pockets could be relics of sedimentary processes. However, little evidence exists to suggest such a distribution of gypsum. Also, regardless of the temperature reduction of the dehydration equilibrium (Eq (1)) caused by lower $\mathrm{H}_{2} \mathrm{O}$ activity, the units in question may not have been buried nor heated sufficiently to bring about dehydration if gypsum was present. Gypsum pseudomorphs after anhydrite are rarely observed, and some structures such as bladed anhydrite clusters in Anhydrite I of DOE 1 and WIPP 13 suggest primary anhydrite growth. Therefore most deposition need not have been gypsum, and the observable evidence indicates that anhydrite is primary. Hence, the gypsum dehydration hypothesis for the WIPP site is at best conjecture.

\subsection{Depositional Processes}

Several depositional processes have been suggested as mechanisms for the deformation observed in the Delaware Basin:

- Penecontemporaneous folding

- Resedimentation

- Slump blocks off reef margins

- Sedimentation on inclined surfaces

Penecontemporaneous folding or movement associated with deposition is commonly diapiric (Gale, 1980). Accompanying this deformation, reexposure of the rising units occurs. Downbuilding has been invoked as the possible syndepositional process in the Delaware Basin (Snider, 1966); however, reexposure features are rarely observed in the Castile evaporites. Also, the thickness of varied Castile sequences that are affected by deformation requires thousands of years for accumulation. Such time spans would imply consolidation before deformation (Kirkland and Anderson, 1970).

Resedimentation of evaporite sequences has been observed in the Mediterranean region (Parea and Ricci-Lucchi, 1972). Such units occur as slumped bodies overlying or replacing normal evaporites in the slope area. Also, gypsum turbidites are associated with sandstone turbidites. These resedimented evaporites are attributed to overloading and to density instability of newly deposited beds. Resedimentation is characterized by chaotic levels in the sequence; such levels 
exhibit slumping and mud flows that are mixed with other clastic material. In contrast, the units of the WIPP area show little chaotic or clastic structures. Also, Kirkland and Anderson's (1970) argument that the deformed units were consolidated at the time of the deformation applies to resedimentation.

Slump blocks off reef margins into the basin would result in olistoliths and blocky units as described above in Parea and Ricci-Lucchi's (1973) resedimented evaporites. Again, such phenomena are not identified in the WIPP area.

If the structures observed were the result of sedimentation on inclined surfaces, then the steepness of such surfaces, up to $70^{\circ}$ (e.g., Anderson and Powers, 1978), would be unreasonable. Again, the inferred consolidation of units argues against such sedimentation on inclined surfaces.

Overall, depositional processes are inconsistent with most of the deformation observed. However, some overturned tight folds as seen in core slabs, inclined unconformities, and scour marks suggest some syndepositional deformation. Still, such structures are only a minor component of deformation near the site. 


\section{Discussion}

\subsection{Data Base}

The WIPP site is one of the most intensely studied bedded evaporite areas in the world. Regional geology is known both from outcrops along the western side of the Delaware Basin and from subsurface petroleum exploration. Petroleum exploration has provided regional gravity, aeromagnetic, and reflection seismic surveys, along with many boreholes. In addition, the potash mining industry has cored many holes through the McNutt ore zone and has ultimately established the geologic structure for the mined-out areas by virtue of several thousand miles of drift.

Local WIPP site characterization has included geologic, hydraulic, geochemical, petrofabric, and geophysical studies. Seventy-eight boreholes have been specifically drilled for WIPP investigations, including nine that penetrate the Castile Formation. The geophysical site surveys include electrical resistivity, seismic refraction and reflection, surface magnetic profiling, first-order leveling, and high-precision gravity. The data base on the site is extensive; the primary task is to interpret these data.

\subsection{Geologic Structure}

Boreholes and seismic reflection surveys have established very gentle dips and minimal structure over most of the site. There is a seismically indicated fault in the southeast quadrant of Zone IV and possible faulting along the sides of an elongated syncline in Sec 29,30 . Both these features appear limited and are near the resolution limits of the present seismic data. Offsets are not expected to exceed 70 to $140 \mathrm{ft}$ (10 to $20 \mathrm{~ms}$ two-way time at $14000 \mathrm{ft} / \mathrm{s}$ ), and recent fault scarps are not present at the surface.

The broad open folds indicated on the seismic time-structure maps may be caused either by geologic structure or by lateral variations in velocity within the overlying formations. Gravity data along with uphole velocity surveys support the existence of lateral variations in velocity and density within the Dewey Lake, Rustler, and Salado Formations.

The principal structural feature near the WIPP site is the DZ. This area was identified as anomalous on seismic reflection data and was later found by drilling to be a structural complex. The areal extent of the $\mathrm{DZ}$ includes all or part of Sec $2-5,8,9,16,17$, and the northern fifth of Sec 20, 21; it is open to the northeast. Boreholes in the DZ that penetrate the Castile Formation include ERDA 6, AEC 7, WIPP 11, WIPP 12, WIPP 13, UNION Fed. 1, POGO Fed. 1, and POGO SCL Fed. 1.

The $\mathrm{DZ}$ is one of several structural complexes of the Castile Formation in the northern Delaware Basin. Most are along the northern periphery of the reefbounded basin, but some occur as isolated structures surrounded by undisturbed strata. We have assumed a common origin for these Castile Formation structures. However, in view of the multiple hypotheses proposed and the limited geologic control, it is possible that several processes are involved. Other structural features in the northern Delaware Basin are sufficiently distinct from the $\mathrm{DZ}$ to assume that they resulted from different processes. These include the "breccia pipes," Bell Lake and Slick Sinks, the igneous dike, and San Simon Swale.

Both borehole and seismic data indicate that the most intensive $\mathrm{DZ}$ deformation is in the Castile and lowermost Salado Formations. Some structure in the underlying Delaware Mountain Group is indicated by the "high" on the top of Anhydrite I at WIPP 11 and the interpreted faulting in Sec 1, T23S, R30E. However, the vertical displacements are much less than are commonly found within the Castile Formation. The shallower structure at the top of the Salado Formation is characterized by broad, low-amplitude, open folds. This includes a syncline over the DZ just north of the site and broad anticlines at ERDA 6 and in Sec 1, 2 of 
T23S, R30E. Above the Salado Formation it is difficult to distinguish geologic structure from the effects of near-surface dissolution.

It is difficult to establish the true form of the geologic structures. The "bull's eye" character of the borehole-controlled structural contour maps, along with the complex structure observed in the cores, strongly implies that present borehole control is insufficient to adequately resolve the structures. The seismic lines support the presence of a more complex structure than that appearing on the boreholecontrolled structural contour maps. For example, line $77 \mathrm{X} 7$, shotpoints 117 through 130 , shows strata dipping toward ERDA 6; the borehole-controlled map indicates a regular anticline.

\subsection{Age of Deformation}

The age of the $\mathrm{DZ}$ is equivocal and likely to remain so. An angular unconformity has been identified at $1744 \mathrm{ft}$ near the middle of the Salado Formation in ERDA 6, indicating that at least some deformation is Permian. However, the unconformity is localized within a normal section, and it may not be related to the DZ structures. Anderson and Powers (1978) noted that the extension fractures in Anhydrite II at ERDA 6 cut across microfolds in the anhydrite/calcite laminations. Kirkland and Anderson (1970) have argued from microfold orientation and relation to larger scale folds that the microfolds developed during Cenozoic tilting of the Delaware Basin. The implication is that the $\mathrm{DZ}$ deformation at least partially postdates the regional tilting. However, the microfolds are irregularly distributed in the basin, and those examined by Kirkland and Anderson may be genetically unrelated to those found at ERDA 6. At ERDA 6 the microfolding and extension fractures may have both been produced by multicomponent deformation during a single deformation event.

Another approach to establishing the age of the $\mathrm{DZ}$ is to apply the axiom that the deformation must predate deposition of the oldest undeformed strata. The $\mathrm{DZ}$ would then have largely formed before middle Salado time. Subsequent deformation such as observed at the top of the Salado Formation is limited to broad, low-amplitude, open folds. In an attempt to establish a minimum age, Jones $(1981, p 18)$ notes that uplifted and arched Triassic rocks near the ERDA 6 borehole are truncated by the flat-lying, undeformed Pliocene Ogallala Formation. He interpreted this as an indication that salt movement was complete before deposition of the Ogallala Formation. However, he does not explain either how the Triassic structure relates to the deeper $\mathrm{DZ}$ or how it is distinguished from near-surface dissolution effects.

The problem with this approach is the inherent assumption that deformations persist upward into overlying formations. Most of the salt deformation processes considered in this report (gravity foundering, dissolution, gravity sliding, and gypsum dehydration) could conceivably occur at depth with little effect on the free surface.

Finally, some age indications might be inferred from the fundamental mechanics of the deformation process. Depositional variations would, of course, be Permian. Gypsum dehydration could also reasonably be assumed a penecontemporaneous process. If the calcium sulfate was originally precipitated from seawater as gypsum, then in a normal geothermal gradient the gypsum is stable at depths of above $800 \mathrm{~m}$ $(2625 \mathrm{ft})$. Below these depths anhydrite is the stable form so that gypsum-anhydrite conversion should have occurred before complete deposition of the Permo-Triassic Dewey Lake Formation. Further discussion of the gypsum-anhydrite system is available in Braitsch (1971, pp 37-40). The gypsum dehydration mechanism would presently be inactive because no gypsum is present in the Castile Formation within the DZ.

The gravity gliding or decollement mechanism is reasonably attributed to regional tilting of the basin, but relating the timing of the $\mathrm{DZ}$ deformation to that timing of regional tilting is complicated. The difficulty is that gravity gliding is the combined result of all the sloping density interfaces in the system, including the free surface. The free surface may be an erosional product whose slope is not directly related to the deeper structure. If we ignore this complication, then the $\mathrm{DZ}$ deformation should be synchronous with the regional tilting. In his discussion of deep-seated salt dissolution, Anderson (1981, p 144) discusses the timing of the regional tilting:

The advanced stage of dissolution in the Delaware Basin developed after a relatively recent history of uplift and exhumation. According to King (1948, pp 120-122) minor uplift may have taken place in early Cenozoic time, but 
the earliest identifiable phase was probably in Miocene to early Pliocene time. The main phase of the uplift occurred in late Pliocene to early Pleistocene time (King, 1948; Hayes, 1964), or perhaps 2-6 m.y. ago. A more recent study since those of King and Hayes has identified the Salt Basin grabens, the Guadalupe Mountains, and the Delaware Basin uplift as features marginal to, and associated with, the Rio Grande rift (Seager and Morgan, 1979). The development of the rift in southern New Mexico culminated about 4 m.y. ago.

A Plio-Pleistocene age can thus be inferred for the gravity gliding mechanism. However, Bachman (1980) argues for an earlier stage of uplift based on an angular unconformity of Cretaceous sediments over Triassic and Permian units; and Chap 2 argues for a pre-Pliocene cutoff.

Age implications of the salt-dissolution mechanism are less certain. According to Anderson (1981) some salt was dissolved from the top of the Castile Formation before deposition of the Salado Formation; from the top of the Salado before deposition of the Rustler Formation; after the Permian and before the Cretaceous; and after the late Cenozoic uplift, tilting, and erosion of the Delaware Basin. A salt dissolution/ deformation process could then have been operative over any of these time spans, including the present.

Gravity foundering results from the sinking of more dense anhydrite through less dense halite. Deformation stress results from the density inversion and will remain "active" until all the anhydrite has settled beneath the halite. In this sense gravitational foundering should be regarded as a possibly ongoing process. In the Appendix it is shown that, for reasonable values of evaporite viscosity, the time required for the $\mathrm{DZ}$ deformation $\left(10^{6} \mathrm{yr}\right)$ is much less than the age of the evaporites $\left(220 \times 10^{6} \mathrm{yr}\right)$. A finite yield strength is assumed to retard deformation in the undisturbed normal areas. Conceivably the gravity foundering mechanism may have operated in the geologic past and the yield strength increased later. If so, the deformation would now be inactive. Unless this conjecture is valid, however, the gravity foundering mechanism implies a potentially active process.

\subsection{The Role of Pressure Solution}

The rarity of twinning and undulatory extinction in WIPP 13 specimens is in stark contrast to the experimentally deformed microtextures of Muller et al (1981). Since temperatures of the deformed anhydrite units probably never exceeded $35^{\circ} \mathrm{C}$ (Powers et al, 1978), annealing has not occurred. Therefore, some mechanism has taken place other than cataclasis, dynamic recrystallization, or dislocation glide. The occurrence of oriented fabrics and stress (pressure) shadows suggests a process of pressure solution (Elliot, 1973; DeBoer, 1977; Robin, 1978).

Pressure solution is the tendency for crystals to dissolve in places where the stress component normal to the crystal face is high, and to precipitate simultaneously in places where this stress component is low (DeBoer, 1977). Confusion can stem from the application of pressure solution to both sedimentary (diagenetic) and tectonic processes. Diagenetic pressure solution occurs in response to gravitational load; tectonic pressure solution occurs in response to weak tectonic/compressive loads (Durney, 1972). There may be gradations between the two, but the WIPP 13 deformation is an example of tectonic pressure solution.

Stress and permanent strain compete in controlling pressure solution (Bosworth, 1981). The role of stress is the migration of chemical components down chemical potential gradients that are functions of stress gradients (Robin, 1978). Strain effects are the variation in dislocation density and in turn the solubility product of the host grain (Bosworth, 1981).

By drawing the analogy to quartz where pressure solution is the dominant deformation mechanism at low metamorphic grades (low temperature), one can suggest that anhydrite (and to some extent halite) may be affected by pressure solution at the low temperatures of the Delaware Basin. Elliot (1973) noted that in halite the presence of impurities such as $\mathrm{H}_{2} \mathrm{O}$ on grain boundaries produces an enormous increase in diffusion rates of grain boundaries. The irregular distribution of such $\mathrm{H}_{2} \mathrm{O}$ impurities may influence the distribution of deformation at the WIPP site. 


\subsection{Rates of Structural Development}

Barrows in the Appendix to this report has calculated that the time required for halokinetic deformation should be of the order of $10^{6}$ ranging from $10^{4}$ to $10^{7} \mathrm{yr}$. Such a time frame would result in a strain rate $3.17 \times 10^{-16} \mathrm{~s}^{-1}\left(1 \times 10^{-8} \mathrm{yr}^{-1}\right)$. In comparison, Heard (1972) uses a strain rate of $3 \times 10^{-14} \mathrm{~s}^{-1}$ as representative of the natural deformation of halite in Gulf Coast salt domes. Carter and Heard (1970) report maximum and minimum strain rates for Gulf Coast salt domes of $10^{-11}$ and $10^{-15} \mathrm{~s}^{-1}$, respectively. Wenkert (1979) calculated an average strain rate for Iranian salt glaciers as $5 \times 10^{-11} \mathrm{~s}^{-1}$, with a range from $10^{-8}$ to $10^{-13} \mathrm{~s}^{-1}$ (note that $10^{-8} \mathrm{~s}^{-1}$ is a very rapid geological strain rate). Such data set bounds on the range strain rates to be considered during site deformation.

In an attempt to scale the differences in deformation parameters between Gulf Coast salt domes and the WIPP site, we can note the strain rate dependence on $\sigma$ and $\mathrm{T}$ for the possible mechanisms: dislocation climb; dislocation creep; Nabarro-Herring and Coble creep; pressure solution (see Table 5-1). Using these dependencies, we can calculate the ratios of strain rate for the Gulf Coast and the WIPP site for each mechanism (Table 5-2). However, ratios of strain rates may not be so easily comparable. One mechanism, pressure solution, may be active at the WIPP site; another mechanism such as dislocation climb may be active in a salt dome.

Absolute strain-rate calculations are not as simple as the comparative ratios above. Table 5-3 shows comparative calculations for pressure solution made by using the equations of Rutter (1976), and for dislocation climb made by using the parameters of Herrmann et al (1982). The greatest source of error is the value used for grain boundary diffusivity since the value differs for a solution in a narrow 3-nm grain boundary as compared to empirically determined diffusivity in a solution of larger volume. This effect is due primarily to electro-viscous interactions between the solution and the grain boundary. Despite the uncertainties, we can note an average scaling factor of $10^{-2}$ to $10^{-3}$ between the growth of Gulf Coast salt domes and structures at the WIPP site. Such factors make Barrow's theoretically calculated rate of $3.2 \mathrm{x}$
$10^{-16} \mathrm{~s}^{-1}$ for halokinetic structures at the WIPP site consistent with Heard's salt dome rate of $3 \times 10^{-14} \mathrm{~s}^{-1}$. From Table 5-4, we can consider the rate of structural development in the context of the long-term WIPP time frame of $\sim 10^{4}$ to $2.5 \times 10^{5} \mathrm{yr}$. Within this time frame, if these processes are active at the WIPP site, a structure the size of the WIPP 12 anticline could develop. The worse case is if a WIPP 12-type structure developed that was centered on the WIPP site. Hence, a WIPP 12-scale anticline could develop within $3 \mathrm{x}$ $10^{5} \mathrm{yr}$; such a structure would not disturb the facility level. Fractures could develop in Castile anhydrites, possibly providing a reservoir for brine accumulation.

However, initiation of a structure centering on the site would be a random event. Site deformation is concentrated on the reef margins. Given that the driving mechanisms for deformation have existed for from 30 to $200 \mathrm{my}$, this areal limitation of deformation argues against both a random process and distribution. Deformation probably develops sequentially. Hence, a more appropriate consideration is the rate at which the deformation front progresses toward the site. A first approximation can be derived from observing an average width of $10 \mathrm{~km}$ for the $\mathrm{DZ}$ adjacent to the reef. If deformation began with basin tilting at $30 \mathrm{my}$, the belt has grown at a rate of $0.3 \mathrm{~mm} / \mathrm{yr}$. At this rate, $4.6 \mathrm{my}$ would be required for the deformation front to progress over the site.

Another approach to such rate calculations is to view the development of the boundary of a structure such as the WIPP 12 anticline as it forms. The geometric layout of this approach is shown in Figure 5-1. As the structure rises, its edge progresses outward. The rate of this progression is in proportion to the rate at which the structure rises times the ratio of the height to the half-width of the structure ( $\mathrm{rh}=\frac{\mathrm{do}}{\mathrm{no}} \mathrm{rv}$ ). Calculations can be made for the progression of the anticline edge toward the site (see Table 5-5). A time of $3 \times 10^{5} \mathrm{yr}$ is derived for this process, by using a relatively rapid strain rate, $10^{-15} \mathrm{~s}^{-1}$, of the bounding calculations. The result probably varies by an order of magnitude either way $\left(10^{4}\right.$ to $\left.10^{6} \mathrm{yr}\right)$.

Hence, within $2.5 \times 10^{5} \mathrm{yr}$, the edge of the deformation could just progress to the site center. However, this is only the edge, where deformation is minimal (a vertical displacement $<10 \mathrm{~m}$ in Castile anhydrites). 


\section{Table 5-1. Strain Rates as Related to the Deformation Mechanism}

Deformation Mechanism*

Pressure Solution

Nabarro-Herring and Coble Creep
Nabarro-Herring Creep

Coble Creep

Dislocation Creep

Dislocation Climb
Source

Rutter (1976)

Raj and Ashby (1970)

(processes combined for polycrystalline material)

\section{Strain Rates}

$\dot{\epsilon} \alpha \sigma \frac{\exp -\mathrm{H}_{\mathrm{f}} / \mathrm{RT}}{\mathrm{RT}}$

$H_{f}$ and $D_{f}$ are used herein for interfacial-fluid, grain-boundary diffusion to avoid confusion in Rutter (1976) in using $\mathrm{H}_{b}$ and $\mathrm{D}_{b}$ for both solid and fluid grain boundary diffusion.

$\epsilon \alpha \sigma \frac{\mathrm{V}}{\mathrm{RTd}^{3}} \mathrm{D}_{\mathrm{v}}\left(1+\pi \frac{\mathrm{w}}{\mathrm{d}}\left(\frac{\mathrm{D}_{\mathrm{b}}}{\mathrm{D}_{\mathrm{v}}}\right)\right)$

- if $\pi \frac{w}{d}\left(\frac{D_{b}}{D_{v}}\right)<<1$, then mechanism called Nabarro-Herring creep

- if $\pi \frac{w}{d}\left(\frac{D_{b}}{D_{v}}\right)>>1$, then mechanism called Coble creep

therefore

$$
\begin{aligned}
& \dot{\epsilon} \alpha \frac{\sigma}{\mathrm{RT}} \exp \left(-\frac{\mathrm{H}_{\mathrm{v}}}{\mathrm{RT}}\right) \\
& \left(1+\pi \frac{\mathrm{w}}{\mathrm{d}} \exp \left(\frac{\mathrm{H}_{\mathrm{v}}-\mathrm{H}_{\mathrm{b}}}{\mathrm{RT}}\right)\right)
\end{aligned}
$$

derived from combined form above

Rutter (1976) (applicable to single spherical grain or polycrystal when

$$
\dot{\epsilon} \alpha \sigma \frac{\exp \left(-\mathrm{H}_{\mathrm{v}} / \mathrm{RT}\right)}{\mathrm{RT}}
$$

$$
\pi \frac{w}{d}\left(\frac{D_{b}}{D_{v}}\right)<<1
$$

Coble (1963) (applicable to single spherical grain)*

$\dot{\epsilon} \alpha \sigma \frac{\exp \left(-\mathrm{H}_{\mathrm{b}} / \mathrm{RT}\right)}{\mathrm{RT}}$

Rutter (1976)

$\epsilon \alpha \sigma^{\mathrm{n}} \frac{\exp \left(-\mathrm{H}_{\mathrm{v}} / \mathrm{RT}\right)}{\mathrm{RT}}$

Weertman (1968) $\dot{\epsilon} \alpha \sigma^{\mathrm{n}} \frac{\exp (-\mathrm{Q} / \mathrm{RT})}{\mathrm{RT}}$

where $Q$ is an empirical parameter from Herrmann et al (1982) 
Table 5-1. (cont)

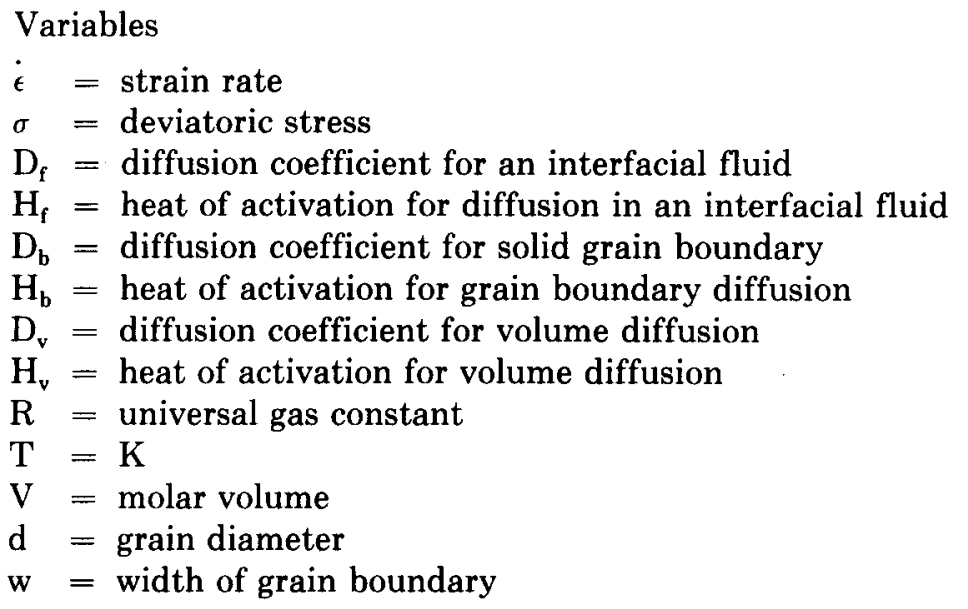

Approximate

$D_{\mathrm{f}}=10^{-10} \mathrm{~cm}^{2} \mathrm{~s}^{-1}$

$\mathrm{D}_{\mathrm{b}}=10^{-20} \mathrm{~cm}^{2} \mathrm{~s}^{-1}$

$\mathrm{D}_{\mathrm{v}}=10^{-30} \mathrm{~cm}^{2} \mathrm{~s}^{-1}$

$\mathrm{H}_{\mathrm{f}}=40 \mathrm{~kJ} \mathrm{~mol}^{-1}$

$\mathrm{H}_{\mathrm{b}}=110 \mathrm{~kJ} \mathrm{~mol}^{-1}$

$\mathrm{H}_{\mathrm{v}}=160 \mathrm{~kJ} \mathrm{~mol}^{-1}$

calculated based on Rutter (1976)

*Definitions of mechanisms used herein are from Stocker and Ashby (1973).

\section{Table 5-2. The Effects on Comparative Strain Rates of Thermal and Stress Differences Between WIPP Site and Gulf Coast Salt Domes}

\begin{tabular}{|c|c|c|c|c|}
\hline \multirow[b]{2}{*}{ Deformation Mechanism } & \multicolumn{2}{|c|}{$\begin{array}{l}\text { Temperature Effects* } \\
(\dot{\epsilon} \text { WIPP/ } / \epsilon \text { Gulf Coast) }\end{array}$} & \multicolumn{2}{|c|}{$\begin{array}{c}\text { Differential Stress Effects** } \\
(\dot{\epsilon} \text { WIPP } / \epsilon \text { Gulf Coast })\end{array}$} \\
\hline & Min & $\operatorname{Max}$ & Min & Max \\
\hline Pressure Solution & 0.82 & 0.52 & $1.2 \times 10^{2}$ & $6 \times 10^{-2}$ \\
\hline Nabarro-Herring and Coble Creep & $3 \times 10^{-1}$ & $10^{-4}$ & $1.2 \times 10^{2}$ & $6 \times 10^{-2}$ \\
\hline Dislocation Creep & $3 \times 10^{-1}$ & $10^{-4}$ & $10^{9}$ & $10^{-6}$ \\
\hline Dislocation Climb & 0.42 & $10^{-3}$ & $10^{9}$ & $10^{-6}$ \\
\hline
\end{tabular}

\footnotetext{
*Conditions used: $\mathrm{T}_{\text {wIPP }}=308 \mathrm{~K}$

$\mathrm{T}_{\text {Gulf Coast }}^{\min }=323 \mathrm{~K} \quad$ Derived by (Heard, 1972) from regional geothermal

$\mathrm{T}_{\mathrm{Gulf}}^{\mathrm{max}}$ Coast $=473 \mathrm{~K} \quad$ gradient; see also Heroy (1968)

${ }^{* *}$ Conditions used: $\sigma_{\text {WIPP }}=5 \times 10^{-1} \mathrm{MPa}$

$$
\begin{aligned}
& \sigma_{\text {Gulf Coast }}^{\min }=8 \times 10^{-3} \mathrm{MPa} \text { derived graphically by } \\
& \sigma_{\text {Gulf Coast }}^{\max }=8 \mathrm{MPa} \quad \text { (Heard, 1972, Figure 12) }
\end{aligned}
$$


Table 5-3. Comparative Strain Rate Calculations for Pressure Solution and Dislocation Climb @ $\sigma=0.5 \mathrm{MPa}$ and $\mathrm{T}=308 \mathrm{~K}\left(35^{\circ} \mathrm{C}\right)$

Pressure Solution

$\dot{\epsilon}=1 / 2 \frac{\mathrm{V} \mathrm{C}_{0} \mathrm{D}_{\mathrm{b}} \mathrm{w}}{{\mathrm{RT} \rho \mathrm{d}^{3}}_{1}} \quad \sigma \quad$ (Rutter, 1976)*

where

$$
\begin{aligned}
\mathrm{V} & =\text { molar volume solid }=27 \mathrm{~cm}^{3} \mathrm{~mole}^{-1} \\
\mathrm{C}_{0} & =\text { concentration of solution }=36.9 \mathrm{~g} / 100 \mathrm{c}^{3} \\
\mathrm{D}_{\mathrm{b}} & =\text { grain boundary diffusivity }=10^{-10} \mathrm{~cm}^{2} \mathrm{~s}^{-1} \\
\mathrm{w} & =\text { width of grain boundary }=3 \mathrm{~nm} \\
\rho & =\text { density of solid }=2.16 \mathrm{~g} / \mathrm{cm}^{3} \\
\mathrm{~d} & =\text { grain diameter }=1 \mathrm{~cm} \\
\dot{\epsilon} & =1.4 \times 10^{-16} \mathrm{~s}^{-1}
\end{aligned}
$$

Dislocation Climb

$\dot{\epsilon}=\mathrm{A}\left(\frac{\sigma}{\mu}\right)^{\mathrm{n}} \exp \left(-\frac{\mathrm{Q}}{\mathrm{RT}}\right) \quad$ (Herrmann et al, 1982)

Parameters (A, $\mu, \mathrm{n}, \mathrm{Q})$ are from Herrmann et al (1982)

$$
\begin{aligned}
& \mathrm{A}=6.7 \times 10^{14} \mathrm{~s}^{-1} \\
& \mathrm{M}=12.4 \mathrm{GPa} \\
& \mathrm{n}=4.9 \\
& \mathrm{Q}=50.2 \mathrm{~kJ} \mathrm{~mole} \mathrm{k}^{-1} \\
& \dot{t}=5.82 \times 10^{-16} \mathrm{~s}^{-1} \\
& \dot{\epsilon}=1.4 \times 10^{-15} \mathrm{~s}^{-1} \quad @ 50^{\circ} \mathrm{C} \quad \text { range of Gulf Coast } \\
& \dot{\epsilon}=5.8 \times 10^{-13} \mathrm{~s}^{-1} \quad @ 200^{\circ} \mathrm{C} \quad \text { salt dome temperatures }
\end{aligned}
$$

*Corrected for iteration error in Rutter (1976) 


\section{Table c-4. Time Required for Developing WIPP 12-Type Anticline at $1 \%$ Volumetric Strain}

Time Required for WIPP 12-Type

Strain Rate

(ं) $\mathrm{s}^{-1}$

Source

Structure to Develop

$5 \times 10^{-11}$

Salt glacier, Wenkert (1979) surface and groundwater weakened

$10^{-11} \quad$ Closure of mined cavity in salt dome, @ (yr) $25^{\circ} \mathrm{C} \sigma=10 \mathrm{MPa}$ (Serata and Gloyna, 1959, in Carter and Heard, 1970)

$3 \times 10^{-14}$

"Characteristic" geologic strain rate for salt dome, Heard (1972)

$10^{-15} \quad$ Gulf Coast salt domes, calculated on basis of $1.2 \times 10^{8} \mathrm{yr}$ of movement (Lower Cretaceous to Recent), $\epsilon=3.2$ to 4.6 , Carter and Heard (1970)

$3.2 \times 10^{-16}$ WIPP Site calculation in this report

6.4

32

$1.1 \times 10^{-4}$

$3.2 \times 10^{5}$

$10^{6}$ 
Table 5-5. Horizontal Rate Calculations for Growth of an Anticline Edge

If

$$
\begin{aligned}
& \mathrm{rh}=\frac{\mathrm{do}}{\mathrm{ho}} \mathrm{rv}, \\
& \frac{\mathrm{do}}{\mathrm{ho}}=\frac{1000 \mathrm{~m}}{60 \mathrm{~m}}=17, \\
& \mathrm{rv}=\frac{\mathrm{h} 1-\mathrm{h} 0}{\mathrm{t}} . \\
& \mathrm{h} 1-\mathrm{h} 0=60 \mathrm{~m} \\
& \mathrm{t}=3 \times 10^{5} \mathrm{yr} @ \dot{\epsilon}=10^{-15} \mathrm{~s}^{-1} .^{*}
\end{aligned}
$$

Then

$$
\begin{aligned}
\mathrm{rv} & =2.0 \times 10^{-4} \mathrm{~m} / \mathrm{yr} \\
\mathrm{rh} & =3.4 \times 10^{-3} \mathrm{~m} / \mathrm{yr}
\end{aligned}
$$

Therefore,

Time for edge of anticline to reach edge of site:

$$
\frac{1000 \mathrm{~m}}{\mathrm{rh}}=3 \times 10^{5} \mathrm{yr}
$$

*assumed most rapid bounding rate

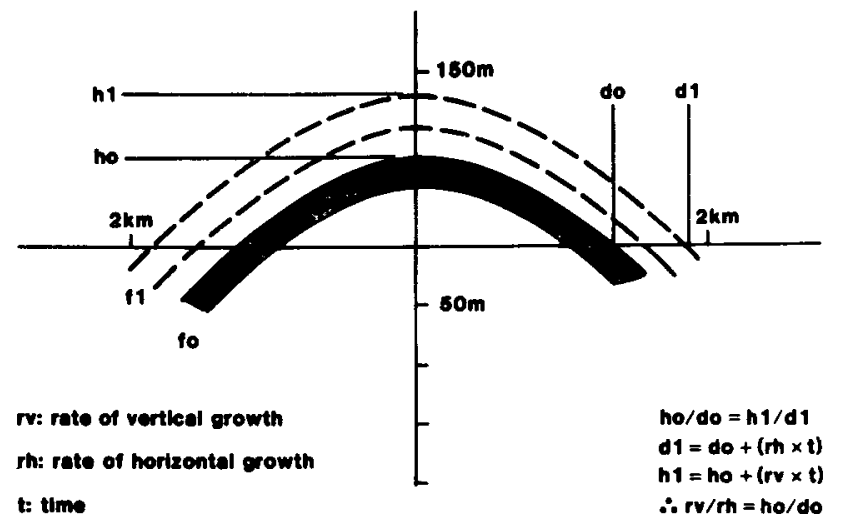

Figure 5-1. Geometry of Boundary Development of a Structure Such as the WIPP 12 Anticline 


\section{Conclusions}

This report is a product of several authors with different backgrounds and working philosophies. Such a diverse group will naturally favor different mechanisms for the origin of site deformation. Still, we basically agree that deformation is largely a result of salt flowage in Halite I and II. Our ideas diverge on what mechanism accounts for this flowage. From the discussion in Chap 5, we have narrowed the working hypotheses to three: (1) syndeposition or closely postdepositional deformation that is gravity-driven and in part initiated by irregular basement topography or by minor basement faulting, (2) gravity foundering, and (3) gravity sliding. However, in the context and the spectrum of objectives of this report, it is not necessary to select one favored mechanism of deformation. It is enough merely to examine the effects of each mechanism and its relevance to site suitability and stability.

\subsection{Constraints on Age of Deformation}

Angular unconformities are observed in the lower Salado of ERDA 6, and Snyder in Chap 2 describes syndepositional troughs in the Salado. Such observations suggest a Permian component of the deformation. But it must be stressed that it is only a component. Jones (1981) noted the Ogallala unconformity at ERDA 6, which implies a pre-Pliocene deformation stage.

Gravity-driven deformation mechanisms require different age constraints. The force for gravity foundering has been present since deposition in the Permian, and is still a force today. Gravity sliding could be associated with basin tilting events that have occurred since deposition through the Mesozoic and Cenozoic; gravity sliding could also be ongoing.

\subsection{Syndepositional to Closely Postdepositional Deformation}

The Salado in the $\mathrm{DZ}$ is smooth relative to the underlying Castile. Broad, open, low-amplitude folds characterize the Salado in these areas. Also, such broad structures are not observed in the stratigraphically higher Dewey Lake Red Beds. These observations led Snyder (in Chap 2) to suggest that the Salado was deposited onto an already deforming Castile surface, and that the deformation was largely complete before deposition of the Dewey Lake. Meso- and microscopic structures also suggest a syndepositional stage of deformation. However, these structures are layer-confined and exhibit opposite senses of asymmetry compared to other sets of structures. These other structures (crenulation folds, boudinage, veins, recrystallized matrix) occurred after consolidation, as suggested by the high number of yearly varves involved in the structure.

The other crucial question in regard to syndepositional processes is to what extent laws of stratigraphic superposition apply in evaporite deformation. The viscosity contrasts between halite and other units are such that the halite may, over geologic time, behave nearly like a fluid relative to the other units. Hence, structures need not be propagated upward through the halite units. By means of halokinetic modeling in the Appendix to this report, Barrows demonstrates that in one such deformation event, stacked units may exhibit different wavelengths similar to the observations that stimulated Snyder's suggestion that the Salado was deposited on a deforming surface.

In summary, strong evidence exists for a syndepositional stage of deformation. But equally strong data suggest that this stage was not the only episode of deformation. 


\subsection{Gravity Foundering}

In the Appendix to this report, Barrows presents a theoretical basis for gravity foundering in the Delaware Basin. This theory, and the similarity of large DZ structures to those produced by scaled centrifuge models, are the main evidence for gravity foundering. However, small-scale structures were not observed that show nonhorizontal flow in the halites, nor were parasitic folds with reverse drag observed. Hence, no actual observations from the WIPP studies uniquely support gravity foundering. Since the driving force for gravity foundering is present throughout the basin, we need to account for the irregular distribution of deformation. In Sections 4.1, 4.3, and 5.4, we have stated the importance of an intergranular fluid to the initiation of deformation. The areal distribution of the $\mathrm{DZ}$ may reflect heterogeneities in fluid content within the evaporite section. However, such relationships have not as yet been empirically demonstrated.

\subsection{Gravity Sliding}

Kirkland and Anderson (1970) and Anderson and Power (1978) observed a parallelism of linear structures in the DZ to basin trends. Such evidence suggests that these structures developed as a tectonic response to basin tilting. This conclusion is supported by the observation of horizontal flow indicators in Halite I and II from holes in the DZ as well as in the weakly deformed beds observed in borehole core from elsewhere in the basin. Still, inconsistencies exist with the gravity-sliding paradigm. Deformation is distributed around the reef with no obvious down-dip piling up. Above in Section 6.3, we have restated the relationship of an intergranular fluid and deformation. The evaporite sequence is weakened enough by the fluid, which allows pressure solution to occur, so that the units can deform under the low stresses and temperatures in the DZ. An irregular distribution of fluids would limit the distribution of deformation to areas where the fluid content is large enough to facilitate deformation. Castile units adjacent to the reef conceptually would have higher water content because of the availability of reef waters and original sedimentation processes. The distribution of deformation features driven by either gravity foundering or by sliding may reflect this; however, these areal heterogeneities have not yet been demonstrated empirically.
The apparent concentration of deformation adjacent to the reef may also result from (besides heterogeneous fluid distribution) flow processes in response to buttressing by the bounding units, irregular topography of the boundary, and fixed-boundary effects. Holes such as AEC 7, 8, ERDA 10, and DOE 1 in relatively undeformed areas compared to ERDA 6, WIPP 11, 12, and 13 still exhibit lateral flow textures in Castile halites. Such observations suggest that salt flowage may exist throughout the basin, but that complex structures (especially in the anhydrite units) are possibly in response to some boundary effect in addition to the effect of irregular fluid distribution.

\subsection{Effects of Various Mechanisms on Site Suitability and Stability}

Distinctions between several mechanisms in geology can often be equivocal. This is the case with the three postulated driving mechanisms. Rather than deciding which mechanism is the dominant one, in the context of this report, we can approach the more significant question of what the effects of the different mechanisms are on WIPP site suitability. The processes can be divided into those now active and those that occurred only in the past. Past deformation events are areally delineated by geophysics and borehole mapping. Hence, complicated structures and (possibly) associated brine reservoirs can be avoided through proper location of the site. One must, however, consider whether the processes responsible for creating existing deformation structures could recur and cause significant deformation at the WIPP site. This concern can be evaluated along with the analyses of ongoing events. If deformation is now active, as may be true of gravity foundering or gravity sliding, the important consideration is the rate of deformation.

Active deformation in the basin is not a random process (see Section 5.5). Deformation structures would sequentially develop, and the boundary of the DZ would progress towards the site. As stated above, the rate of this sequential development is the important consideration. In Section 5.5, the growth of the DZ toward the WIPP site can be calculated at several rates: $4.2 \times 10^{6}$ yr (using $30 \mathrm{my}$ for initiation of deformation and a width of the DZ of $10 \mathrm{~km}$ ); $3 \times 10^{5} \mathrm{yr}$ 
@ $\dot{\epsilon}=10^{-15} \mathrm{~s}^{-1}$ and $3 \times 10^{6} @ \dot{\epsilon}=10^{-16} \mathrm{~s}^{-1}$ (using progression calculation for WIPP 12 anticline edge). There is a remarkable agreement from the various forms of calculation that reasonable strain rates for the WIPP site range between $10^{-15}$ and $10^{-16} \mathrm{~s}^{-1}$. Hence, in predicting the history of the facility through $2.5 \times 10^{5}$ yr we can not exclude the possibility that the edge of deformation will reach under the facility near the very end of the time frame. This is a bounding but not absolute calculation. From analogy to the WIPP 12 structure, the size of the developing structure will not displace the repository level. Minor deformation of the Castile units could develop; fractures in Castile anhydrites could provide a reservoir for brine accumulation. Fractures that would connect the mid-Salado and the Castile anhydrites could not develop in halites at the strain rates involved. Although a brine reservoir could develop at depth, progressing deformation would not directly jeopardize the facility.

\section{References}

R. Y. Anderson, "Correlation and Structural Relationships of the Castile-Salado Evaporite Sequence in ERDA 6, AEC 7, and AEC 8 Boreholes, Eddy and Lea Counties, New Mexico," Open-File Rpt to Sandia (1976).

R. Y. Anderson and D. W. Powers, "Salt Anticlines in Castile-Salado Evaporite Sequence, Northern Delaware Basin, New Mexico," in G. S. Austin, Geology and Mineral Deposits of Ochoan Rocks in Delaware Basin and Adjacent Areas, Circular 159 (Santa Fe, NM: New Mexico Bureau of Mines and Mineral Resources, 1978), pp 79-83.

R. Y. Anderson, Deep-Seated Salt Dissolution in the Delaware Basin, Texas and New Mexico, Special Publication 10 (NM Geol Soc, 1981), pp 133-145.

E. V. Artyushkov, "Stresses in the Lithosphere Caused by Crustal Thickness Inhomogeneities," JGR 78:7676-7708 (1973).

A. A. Arzi, "Remote Sensing of Subsurface Karst by Microgravity," in J. S. Tolson and F. L. Doyle, ed, Proc of the 12th Intl Congress on Karst Hydrology (Huntsville, AL: UAH Press, 1977), pp 271-272.

G. O. Bachman, "Cenozoic Deposits of Southeastern New Mexico and an Outline of the History of Evaporite Dissolution," USGS J of Res 4:2 (1976), pp 135-149.

G. O. Bachman, Regional Geology and Cenozoic History of Pecos Region, Southeastern New Mexico, Open-File Report 80-1099 (USGS, 1980).

L. J. Barrows and C. J. Langer, "Gravitational Potential as a Source of Earthquake Energy," Tectonophysics 78:237255 (1981).

Bell and Murphy and Assoc., Inc., Geophysical Investigation of the Waste Isolation Pilot Plant, Report for USDOE (1979).
W. Bosworth, "Strain-Induced Preferential Dissolution of Halite," Tectonophysics 78:509-525 (1981).

O. Braitsch, Salt Deposits, Their Origin and Composition (Berlin: Springer-Verlag, 1971).

L. Chaturvedi, ed, WIPP Site and Vicinity, Geologic Field Trip: New Mexico State Environment Evaluation Group, EEG-7 (1980).

R. L. Cobel, "A Model for Boundary Diffusion Controlled Creep in Polycrystalline Materials," J Appl Phys 34:1679-1682 (1963)

R. B. DeBoer, "On the Thermodynamics of Pressure Solution - Interaction Between Chemical and Mechanical Forces," Geochimica et Cosmochimica Acta 41:249-256 (1977).

K. A. De Jong and R. Scholten, ed, Gravity and Tectonics (New York: John Wiley and Sons, 1973).

J. M. Dennison, "Gravity Tectonic Removal of the Blue Ridge Anticlinorium to Form Valley and Ridge Province," GSA Bull 87:1470-1476 (1976).

US Department of Energy, Waste Isolation Pilot Plant Safety Analysis Report, Vol 1-5 (Albuquerque, NM: US DOE, WIPP Project Office, 1980; rev 1980 and 1981).

M. B. Dobrin, Consultant Report on Seismic Survey of WIPP Site Conducted by Bechtel in 1979, Report for the US DOE (1979).

D. W. Durney, "Solution-Transfer, an Important Geological Deformation Mechanism," Nature 235:315-317 (1972).

D. Elliot, "Diffusion Flow Laws in Metamorphic Rocks," GSA Bull 84:2645-2664 (1973).

A. S. Gale, "Penecontemporaneous Folding, Sedimentation and Erosion in Campanian Chalk Near Portsmouth, England," Sedimentology 27:137-151 (1980).

D. R. Gray, "Morphologic Classification of Crenulation Cleavage," J of Geol 85:229-235 (1977).

P. T. Hayes, Geology of the Guadalupe Mountains, New Mexico, USGS Prof Paper 446 (1964).

H. C. Heard, "Steady-State Flow in Polycrystalline Halite at Pressure of 2 Kilobars," in H. C. Heard, I. V. Borg, N. L. Carter, C. B. Raleigh, ed, Flow and Fracture of Rocks (Geophys Monogr Series), Am Geophys Union 76:191-210 (1972).

H. C. Heard and W. W. Rubey, "Tectonic Implications of Gypsum Dehydration," GSA Bull 77:741-760 (1966).

J. L. Hern, D. W. Powers, and L. J. Barrows, Seismic Reflection Data Report, Waste Isolation Pilot Plant (WIPP) Site, Southeastern New Mexico, SAND79-0264, Vol 1 and 2 (Albuquerque, NM: Sandia National Laboratories, 1979).

W. B. Heroy, "Thermicity of Salt as a Geologic Function," in R. B. Mattox et al, eds, Saline Deposits, GSA Special Papers 88:619-629 (1968).

W. Herrmann, W. R. Wawersik, and S. T. Montgomery, Review of Creep Modeling for Rock Salt (Albuquerque, NM: Sandia National Laboratories, 1982). 
W. R. Jacoby, "Instability in the Upper Mantle and Global Plate Movements,” JGR 75 (29):5671 (1970).

C. L. Jones, Geologic Data for Borehole ERDA 6, Eddy County, New Mexico, Open-File Report 81-468 (USGS, 1981).

C. L. Jones, "The Occurrence and Distribution of Potassium Minerals in Southeastern New Mexico," NM Geol Soc Guidebook 5th Field Conf (1954), pp 107-112.

P. B. King, Geology of the Southern Guadalupe Mountains, Texas, USGS Professional Paper 214 (1948).

D. W. Kirkland and R. Y. Anderson, "Microfolding in the Castile and Todilto Evaporites, Texas and New Mexico," GSA Bull 81:3259-3282 (1970).

S. J. Lambert, Geochemistry of Delaware Basin Ground Waters, Circular 159 (Santa Fe, NM: New Mexico Bureau of Mines and Mineral Resources, 1978), pp 32-38.

S. J. Lambert, Dissolution of Evaporites in and Around the Delaware Basin, Southeast New Mexico and West Texas, SAND82-0461 (Albuquerque, NM: Sandia National Laboratories, February 1983).

G. J. Long and Associates, Report: Interpretation of Geophysical Data, Los Medaños and Vicinity, Lea and Eddy Counties, New Mexico, Report to Sandia Laboratories (1976).

J. M. McGough, DOE-AL, Ltr on WIPP Surface Control Zones, WIPP, JMM 83-0125, February 17, 1983.

R. C. Milici, "Structural Patterns in the Southern Appalachians - Evidence for a Gravity Slide Mechanism for Alleghenian Deformation," GSA Bull 86:1316-1320 (1975).

W. H. Muller and U. Briegel, "The Rheological Behavior of Polycrystalline Anhydrite," Eclogue Geol Helv 71:397407 (1978).

W. H. Muller, S. M. Schmid, and U. Briegel, "Deformation Experiments on Anhydrite Rocks of Different Grain Sizes: Rheology and Microfabric," Tectonophysics 78:527543 (1981).

L. L. Nettleton, Gravity and Magnetics in Oil Prospecting (New York: McGraw-Hill, 1976).

G. Omnes, "High Accuracy Gravity Applied to the Detection of Karstic Cavities," in J. S. Tolson and F. L. Doyle, ed, Proc of the 12th Intl Congress on Karst Hydrology (Huntsville, AL: UAH Press, 1977), pp 273-284.

G. C. Parea and R. Ricci-Lucchi, "Resedimented Evaporites in the Periadriatic Trough (Upper Miocene, Italy)," Israel J of Earth-Sciences 21:125-141 (1973).

D. W. Powers, S. J. Lambert, S-E. Shaffer, L. R. Hill, and W. D. Weart, ed, Geological Characterization Report, Waste Isolation Pilot Plant (WIPP) Site, Southeastern New Mexico, SAND78-1596, Vol I and II (Albuquerque, NM: Sandia Laboratories, 1978).

R. A. Price, "Gravitational Sliding and the Foreland Thrust and Fold Belt of the North American Cordillera Discussion," GSA Bull 82:1133-3317 (1971).

R. A. Price, "Large-Scale Gravitational Flow of Supracrustal Rocks, Southern Canadian Rockies," in De Jong and Scholten, ed, Gravity and Tectonics (New York: John Wiley and Sons, 1973), pp 491-502.
R. Raj and M. F. Ashby, "On Grain Boundary Sliding and Diffusional Creep," Trans Met Soc AIME 2:113 (1971).

H. Ramberg, Gravity, Deformation and the Earth's Crust (London: Academic Press, 1981).

F. Ricci-Lucchi, "Resedimented Evaporites: Indicators of Slope Instability and Deep-Basin Conditions in Periadriatic Messenian (Apennines Foredeep, Italy)," in W. Drooger, ed, Messenian Events in the Mediterranean (Amsterdam: North Holland Publishing Co., 1973), pp 124-141.

P-Y. F. Robin, "Pressure Solution at Grain-to-Grain Contacts," Geochem et Cosmochimica Acta 42:1383-1398 (1978).

E. H. Rutter, "The Kinetics of Rock Deformation by Pressure Solution," Phil Trans Royal Soc London, Ser A 283:203-209 (1976).

Sandia National Laboratories and US Geological Survey, Basic Data Report for Drillhole WIPP 11 (Waste Isolation Pilot Plant-WIPP), SAND79-0272 (Albuquerque, NM: Sandia National Laboratories, 1982).

Sandia National Laboratories and US Geological Survey, Basic Data Report for Drillhole WIPP 33 (Waste Isolation Pilot Plant-WIPP), SAND80-2011 (Albuquerque, NM: Sandia National Laboratories, 1981).

S. M. Schmid, J. N. Boland, and M. S. Paterson, "Superplastic Flow in Fine-Grained Limestone," Tectonophysics 43:257-291 (1977).

W. R. Seager and P. Morgan, "Rio Grande Rift in Southern New Mexico, West Texas, and Northern Chihuahua," in R. E. Riecker, ed, Rio Grande Rift: Tectonics and Magmatism (Washington, DC: AGU, 1979), pp 87-106.

H. I. Snider, "Stratigraphy and Associated Tectonics of the Upper Permian Castile-Salado-Rustler Evaporite Complex, Delaware Basin, West Texas and Southeast New Mexico" (PhD diss, University of New Mexico, 2 parts; $p 2$ charts, 1966).

R. L. Stocker and M. F. Ashby, "On the Rheology of the Upper Mantle," Reviews of Geophysics and Space Physics 11:391-426 (1973).

M. Sweeting, Karst Landforms (New York: Columbia University Press, 1973).

R. W. VanBemmelen, "Plate Tectonics and the Inundation Model - A Comparison," Tectonophysics 32:145-182 (1976).

R. H. Vernon, Metamorphic Processes: Reactions and Microstructure Development (New York: John Wiley and Sons, 1975).

K. H. Waters, Reflection Seismology (New York: John Wiley \& Sons, 1978).

J. Weertman, "Dislocation Climb Theory of SteadyState Creep," Trans Amer Soc Metals 61:681-694 (1968).

D. D. Wenkert, "The Flow of Salt Glaciers," Geophys Res Ltrs 6:523-526 (1979).

H. J. Zwart and T. J. Calon, "Chloritoid Crystals From Curaglig; Growth During Flattening or Pushing Aside," Tectonophysics 43:477-486 (1977). 


\title{
APPENDIX
}

\section{Halokinetic* Development of the Disturbed Zone}

\author{
Larry Barrows \\ Sandia National Laboratories \\ Albuquerque, NM 87185
}

November 1981

(Rev. May 6, 1982)

\begin{abstract}
Note
This report concerns the mechanical development of the disturbed zone and, to a lesser extent, the migration of brine pockets. It is assumed that the reader is familiar with the WIPP, its local geology, and the general concepts of gravitational tectonics as developed by Hans Ramberg.

No attempt is made to assess the implications of this material upon suitability of the site. Such assessment requires careful consideration of this material along with many other factors.
\end{abstract}

${ }^{*}$ Halokinesis-autonomous, isostatic movement of salt (Halbouty, 1967) 


\section{Abstract}

The disturbed zone was initially identified as an area of chaotic seismic reflection data in the northern part of the WIPP site. Boreholes have encountered complex deformation within the Castile Formation and a broad gentle syncline near the top of the Salado Formation. The underlying Delaware Mountain Group is relatively undeformed.

The disturbed zone can be attributed to gravitational foundering of the massive anhydrite members of the Castile Formation through the less dense halite. Following Ramberg (1981, Chap 7), the process was analyzed as the growth of sinusoidal waves in a system of viscous layers with differing thicknesses, viscosities, and densities. Analysis of the density stratification of the WIPP site is consistent with intense short-wavelength deformation within the Castile Formation; less-intense longer wavelength deformation at the Rustler/Salado interface; and little or no deformation at the free surface, repository horizon, and Delaware Mountain Group. For effective evaporite viscosities similar to those used in modeling salt diapirs $\left(10^{17}\right.$ to $\left.10^{19} \mathrm{P}\right)$, the rate of deformation is 0.5 to $0.005 \mathrm{~cm} / \mathrm{yr}$.

Centrifuge models of orogenic belts described by Ramberg (1981, Chap 15) were reinterpreted as models of foundering anhydrite layers. The models provide a qualitative appreciation of the structural complexity resulting from gravitational foundering.

Other centrifuge models were reinterpreted as representing the rise of brine pockets through the evaporite section. The models suggest upward brine velocities of about $1 \mathrm{~cm} / \mathrm{yr}$.

Disturbed-zone deformations are the expected result of the WIPP density stratification, along with reasonable estimates of evaporite viscosity. The stability of undeformed areas is less understood, but may be due to a finite yield strength of the rocks. 


\section{Contents}

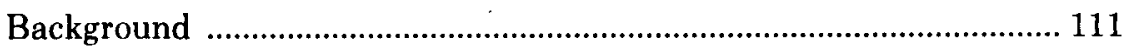

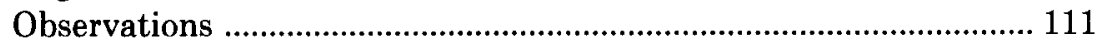

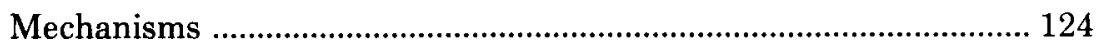

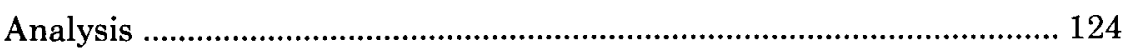

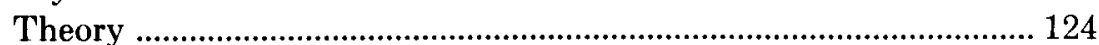

WIPP Models ............................................................................ 127

Rates of Growth ............................................................................ 131

Centrifuge Models ......................................................................... 133

Gravitational Foundering ............................................................. 133

Migration of Brine Pockets ........................................................ 137

Discussion ........................................................................ 139 


\section{Background}

\section{Observations}

The "disturbed zone" (DZ) is loosely defined as an area of chaotic seismic reflection data in the northern part of the WIPP site. Figure A-1 is a representative seismic line (77X5) crossing the DZ. Figures A-2 through A-5 are seismic time structure maps, and Figures A-6 through A-8 are seismic isochron maps. These maps show the areal extent of the DZ (Figures A-2, A-3), the absence of deformation in the underlying Delaware Mountain Group (Figures A-4, A-5, $\mathrm{A}-8)$, and thickness variations within and on the periphery of the DZ (Figures A-6, A-7). The seismic lines (e.g., Figure A-1) indicated a blocky chaotic structure with abrupt offsets (faults) and changes in dip between units. Changes in the seismic character indicate variations in unit thicknesses and/or acoustic properties.

Figures A-9, A-10, and A-11 show correlations between those boreholes in the $\mathrm{DZ}$ that penetrate the Castile Formation. The units in the Salado Formation are convenient markers on the compensated neutron density logs. Within the Castile Formation the dark bands are anhydrite; the light areas are halite (as indicated on the density logs). Brine encounters are marked by asterisks. The top of the Salado Formation at borehole ERDA 6 is higher than at the flanking boreholes AEC 7, AEC 8, and Union Fed. 1.

Figure A-12 is a top-of-Salado structural contour map prepared by C. L. Jones, USGS, from borehole control. There is a broad gentle syncline in the area of the $\mathrm{DZ}$, but no indication of deformations as intense as those encountered in the underlying Castile Formation. On Figure A-12 there is a broad gentle anticline to the southwest of the WIPP site.

Figure A-13 is that portion of seismic line 76SAN2 that crosses this area. Locations of this line segment and the Belco-Federal well (a brine encounter) are indicated on Figure A-12. Seismic line 76SAN2 was gathered with field parameters typical of petroleum exploration in the region. It does not resolve structural features within the Castile Formation nearly so well as the seismic lines gathered with modified field parameters (the $77 \mathrm{X}, 78 \mathrm{Y}$, and 78GG surveys). Despite the relatively poor resolution, the line does indicate structure within the Castile Formation. The seismic character of this structure is similar to that portion of line 76SAN3 that is in the $\mathrm{DZ}$ north of the site.

There appears to be a spatial relation between low-amplitude folding at the top of the Salado Formation and areas of disturbed structures within the Castile Formation. The top of Salado deformations involves both anticlines and synclines.

The DZ is one of many Castile Formation structural complexes in the northern Delaware Basin. Most of the others are known only from borehole data, although some are indicated on proprietary petroleum exploration seismic lines. H. Snider (1966) presents documented contour maps prepared from the borehole data available at that time. R. Y. Anderson (1978) presents contour maps prepared from the larger data set then available. In Anderson's report the well locations are indicated, but the data are not posted on the maps nor tabulated in the text.

Figure A-14 is a structural contour map prepared from the posted borehole control. The contoured horizon is the top of the first massive halite encountered below the uppermost massive anhydrite in the Castile Formation. Generally (but not always) this is the top of Halite II. The data points were taken from a preliminary contour map by R. Snyder, USGS, and contoured by L. Barrows. Some of the structures evident at other stratigraphic horizons are not indicated at this mapped horizon (see Snider, 1966, or Anderson, 1978). The "bull's-eye" character indicates that structures are not resolved by the present borehole control, and it is likely that additional structures remain undetected in the basin. Nevertheless, Figure A-14 indicates the general distribution of Castile Formation structural complexes in the northern Delaware Basin. 


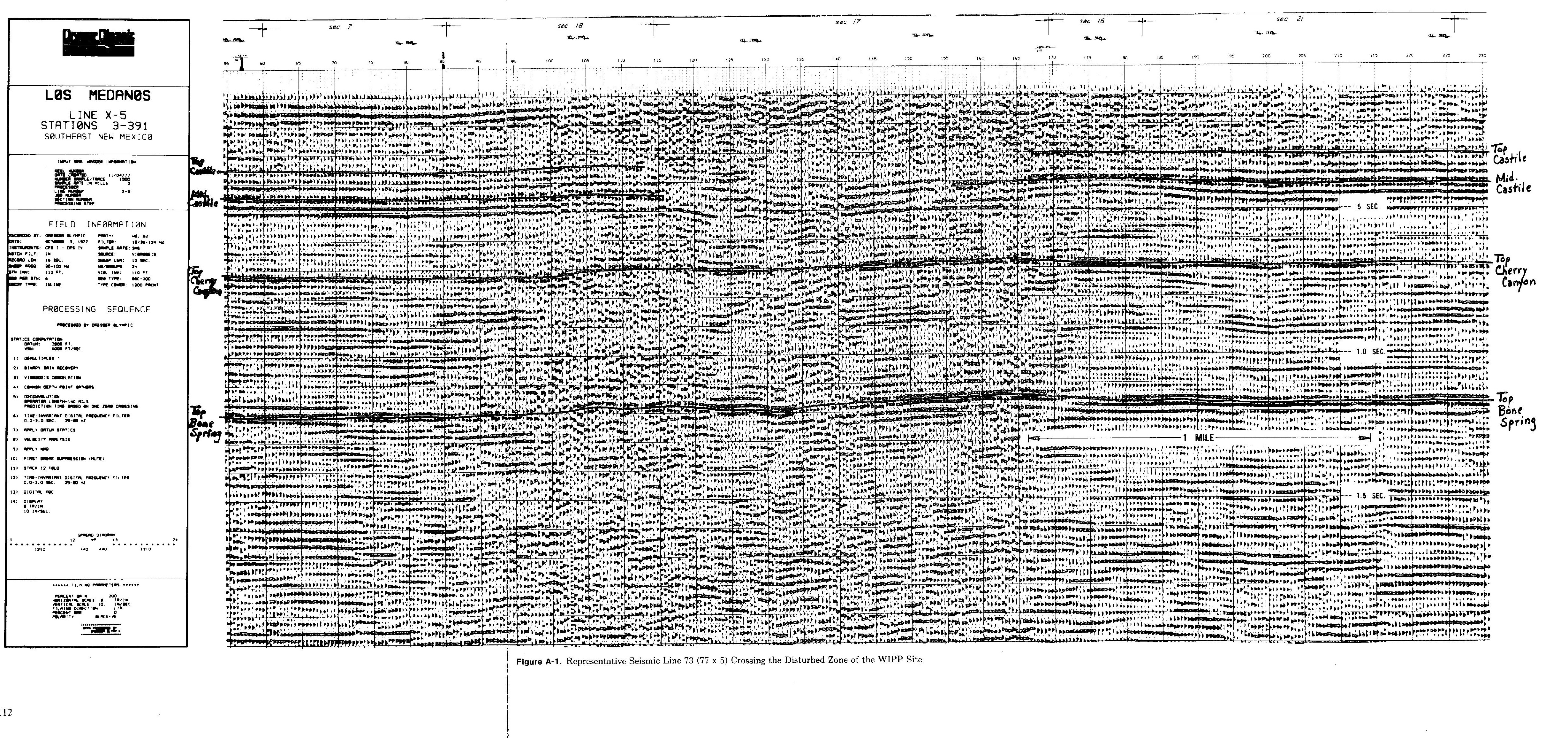




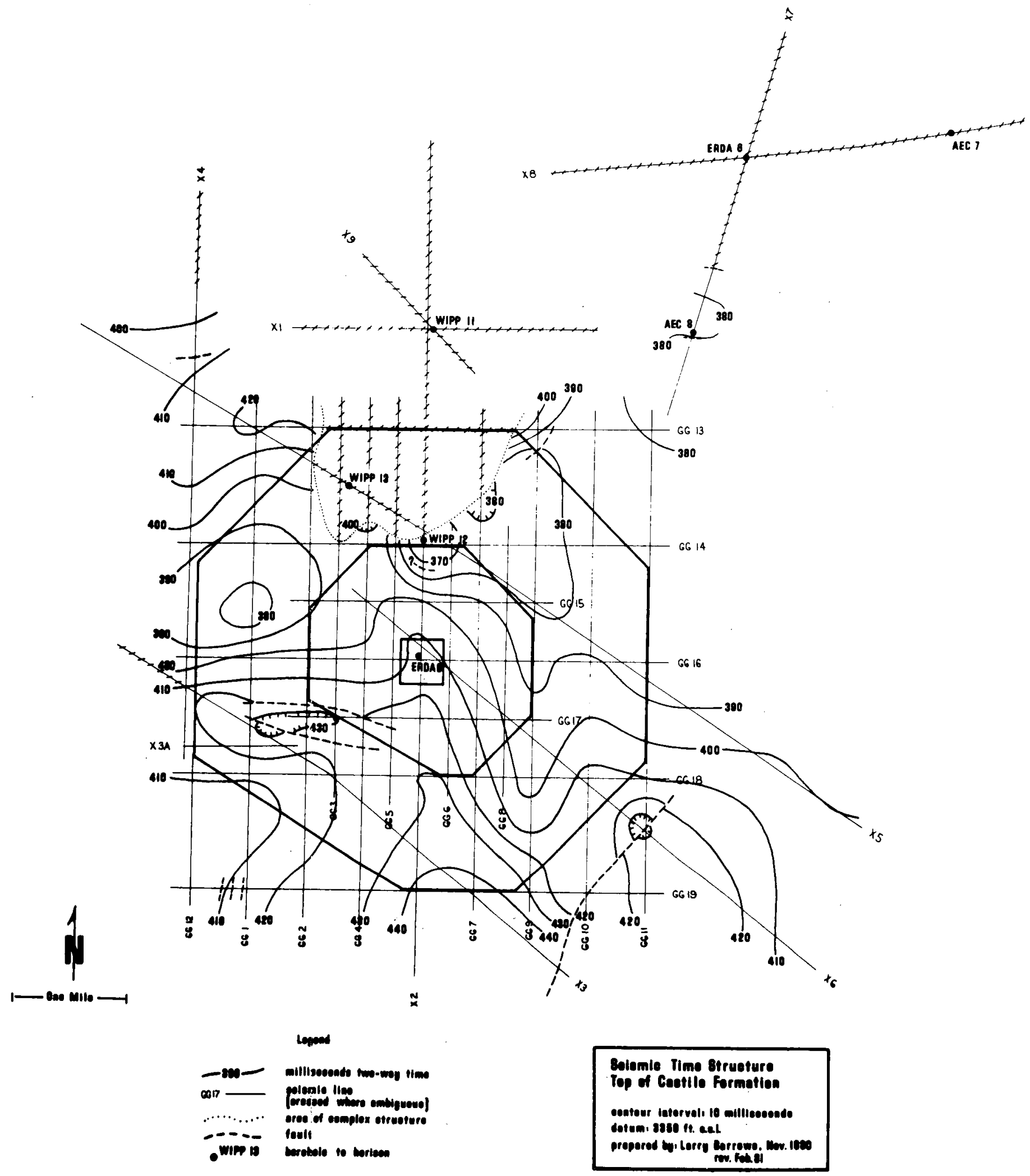

Figure A-2. Seismic Time Structure - Top of Castile Formation 

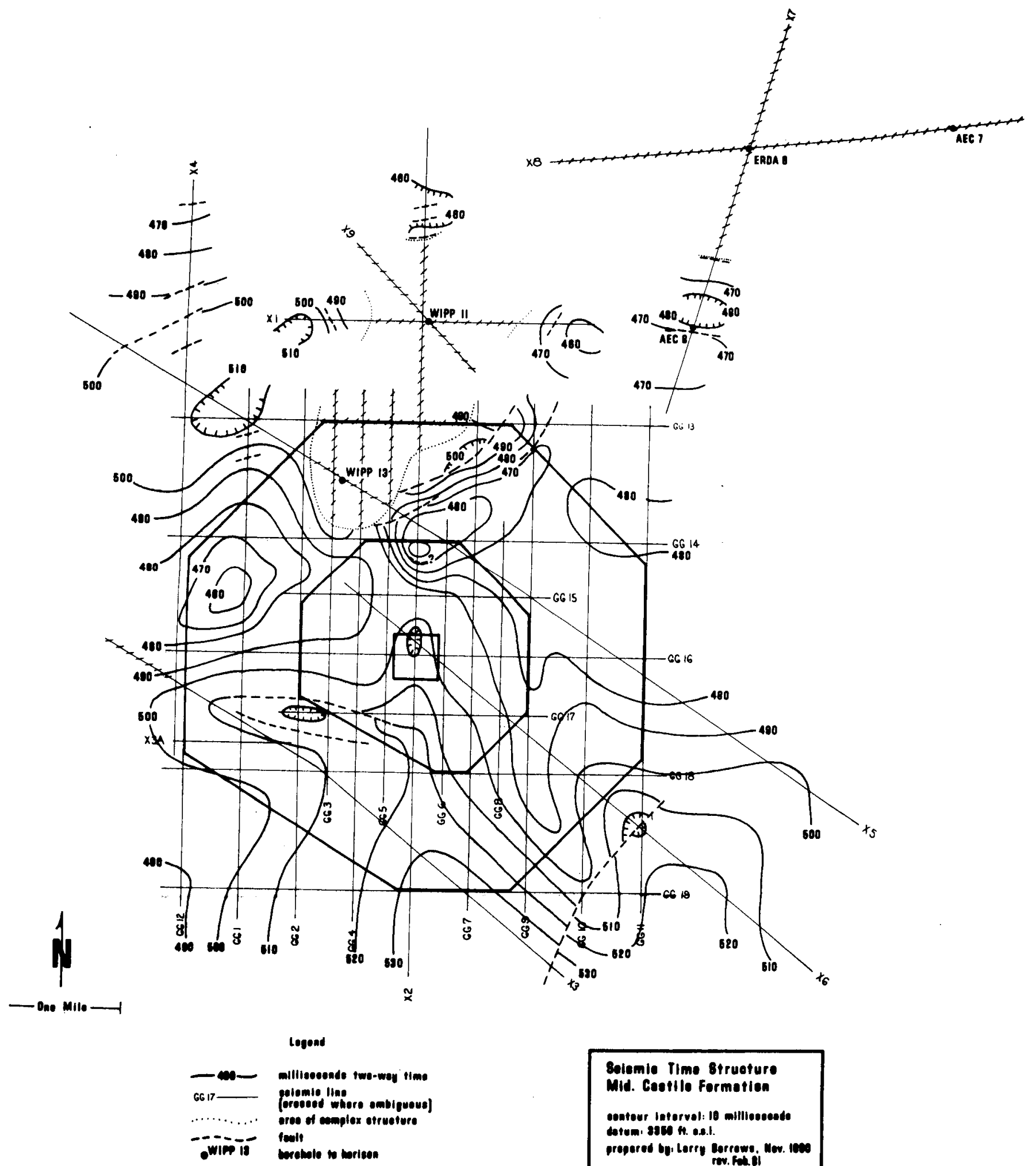

Seiemie Time strueture Mid. Cestlle Formetien

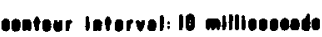
catum. sact H. a.s.

prepared by lorry Marrown. Mow. Ines nev. Fentel

Figure A-3. Seismic Time Structure - Mid-Castile Formation 


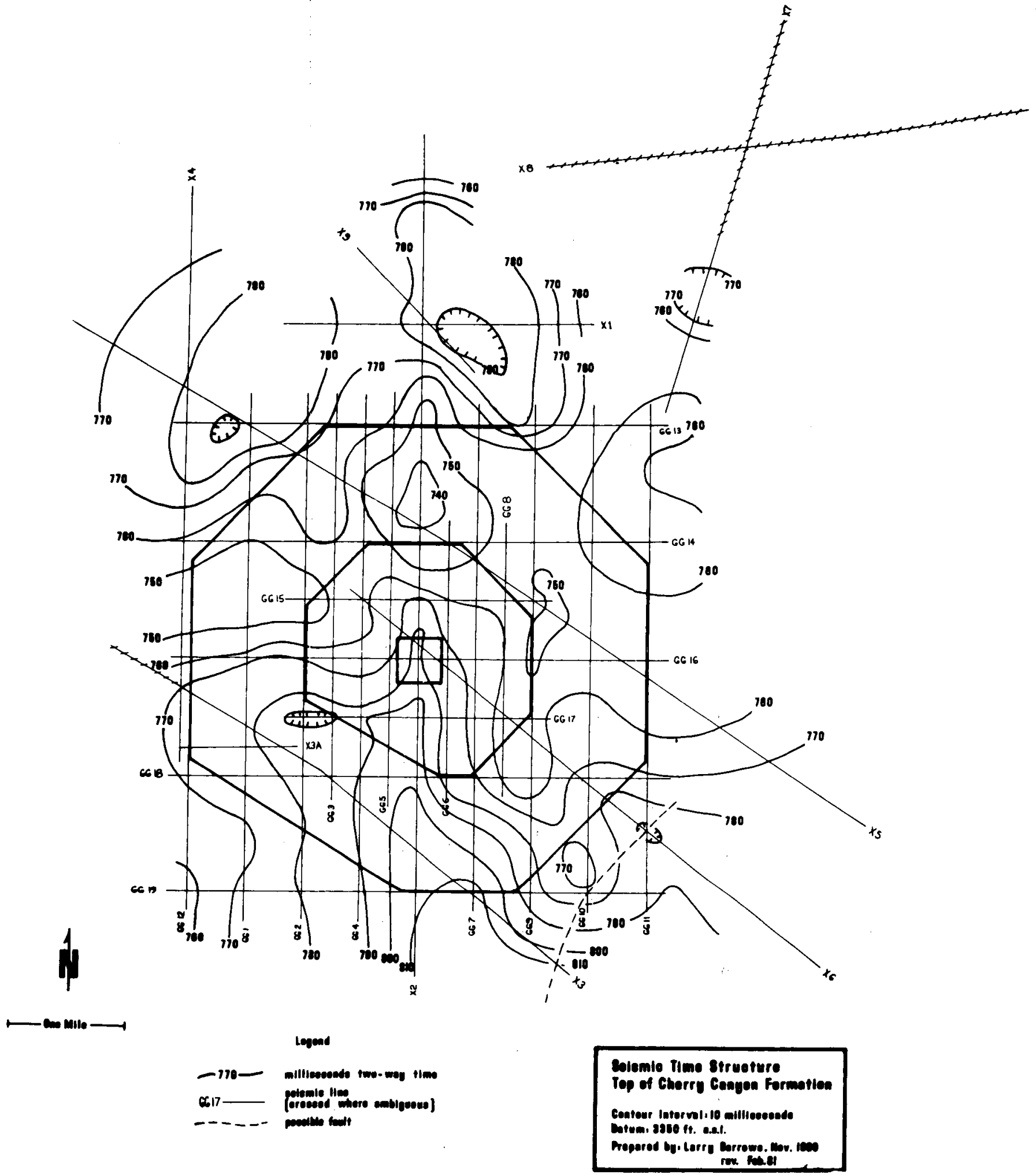

Figure A-4. Seismic Time Structure - Top of Cherry Canyon Formation 


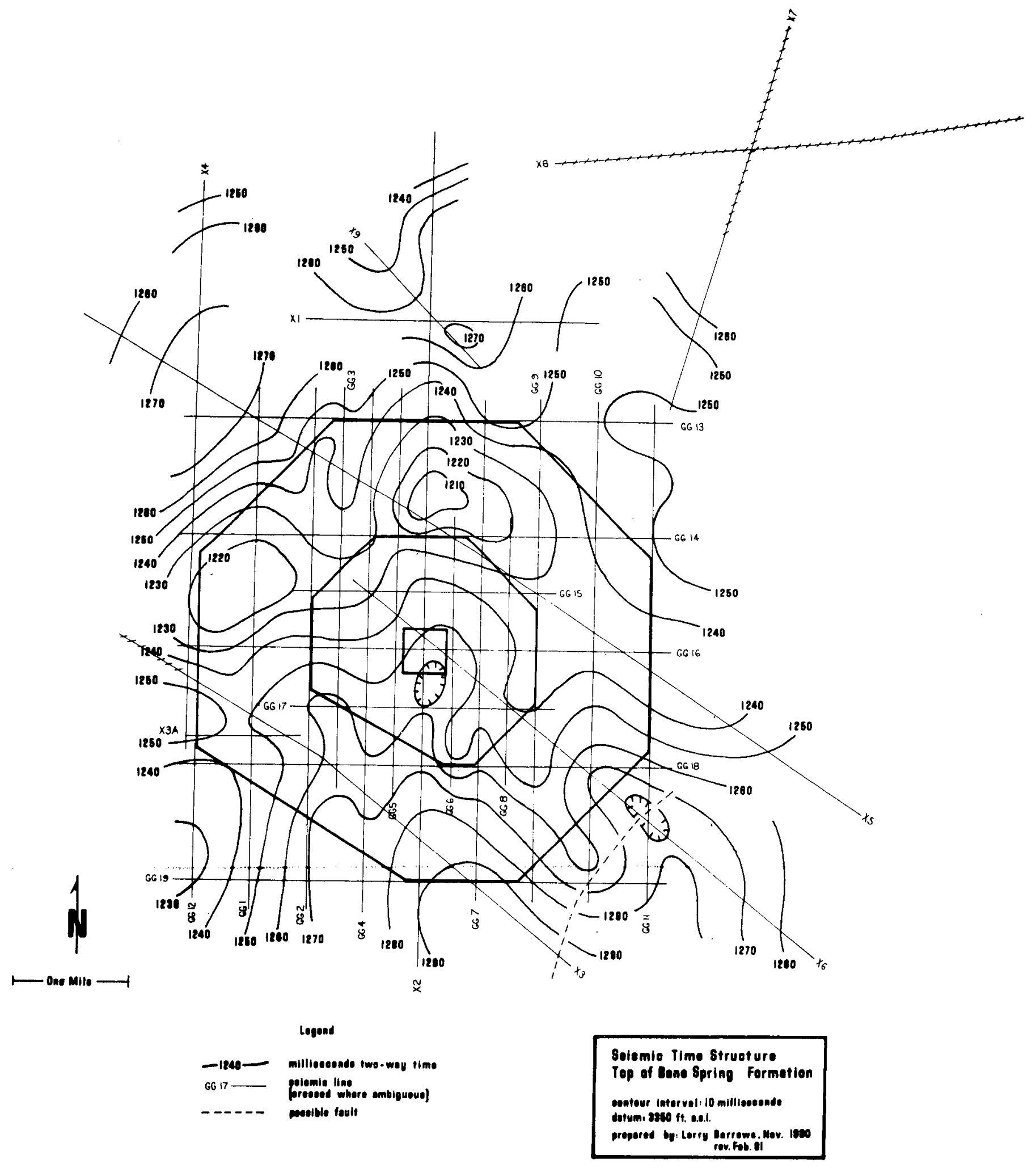

Figure A-5. Seismic Time Structure - Top of Bone Spring Formation 


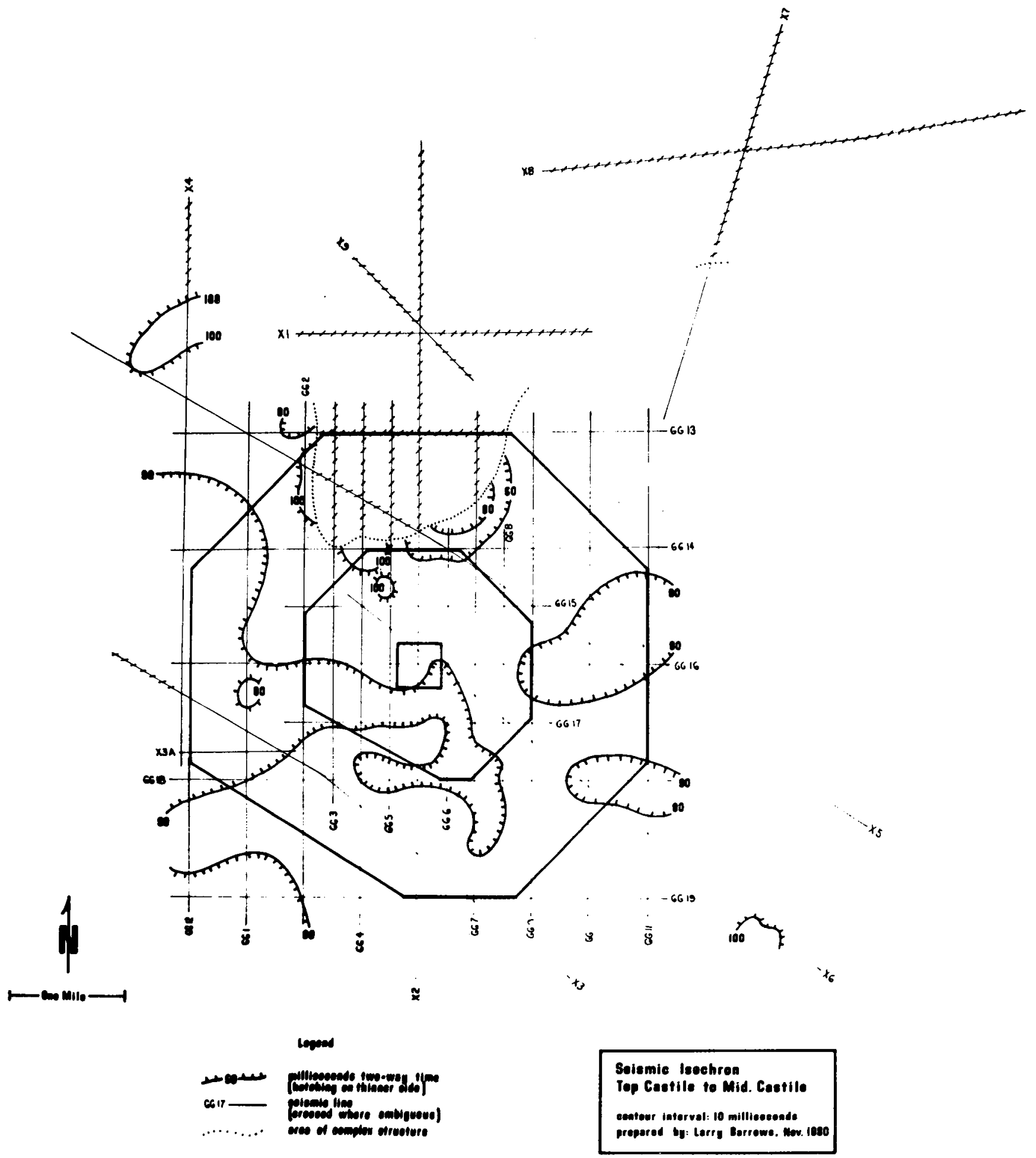

Figure A-6. Seismic Isochron - Top Castile to Mid-Castile 


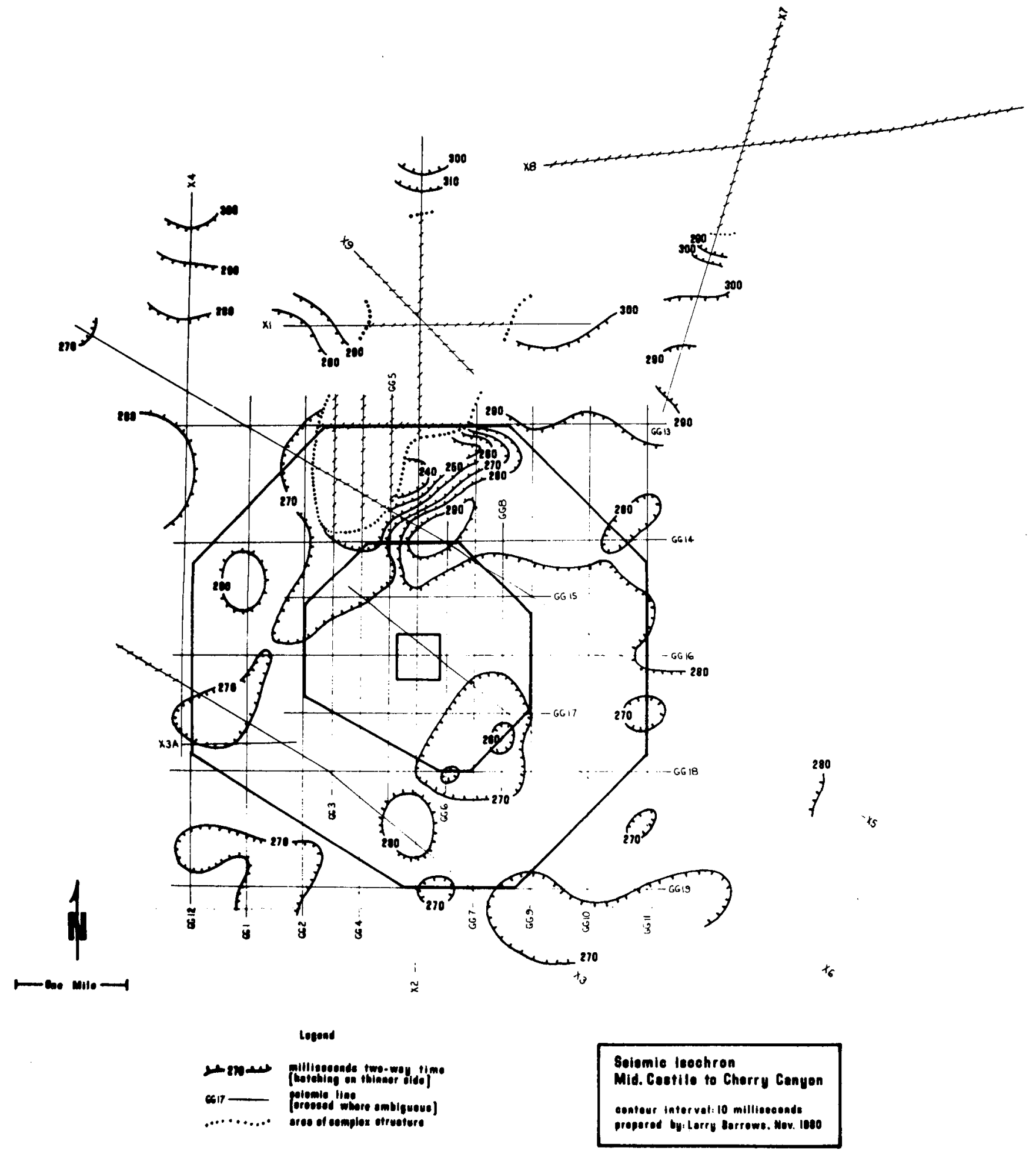

Figure A-7. Seismic Isochron - Mid-Castile to Cherry Canyon 


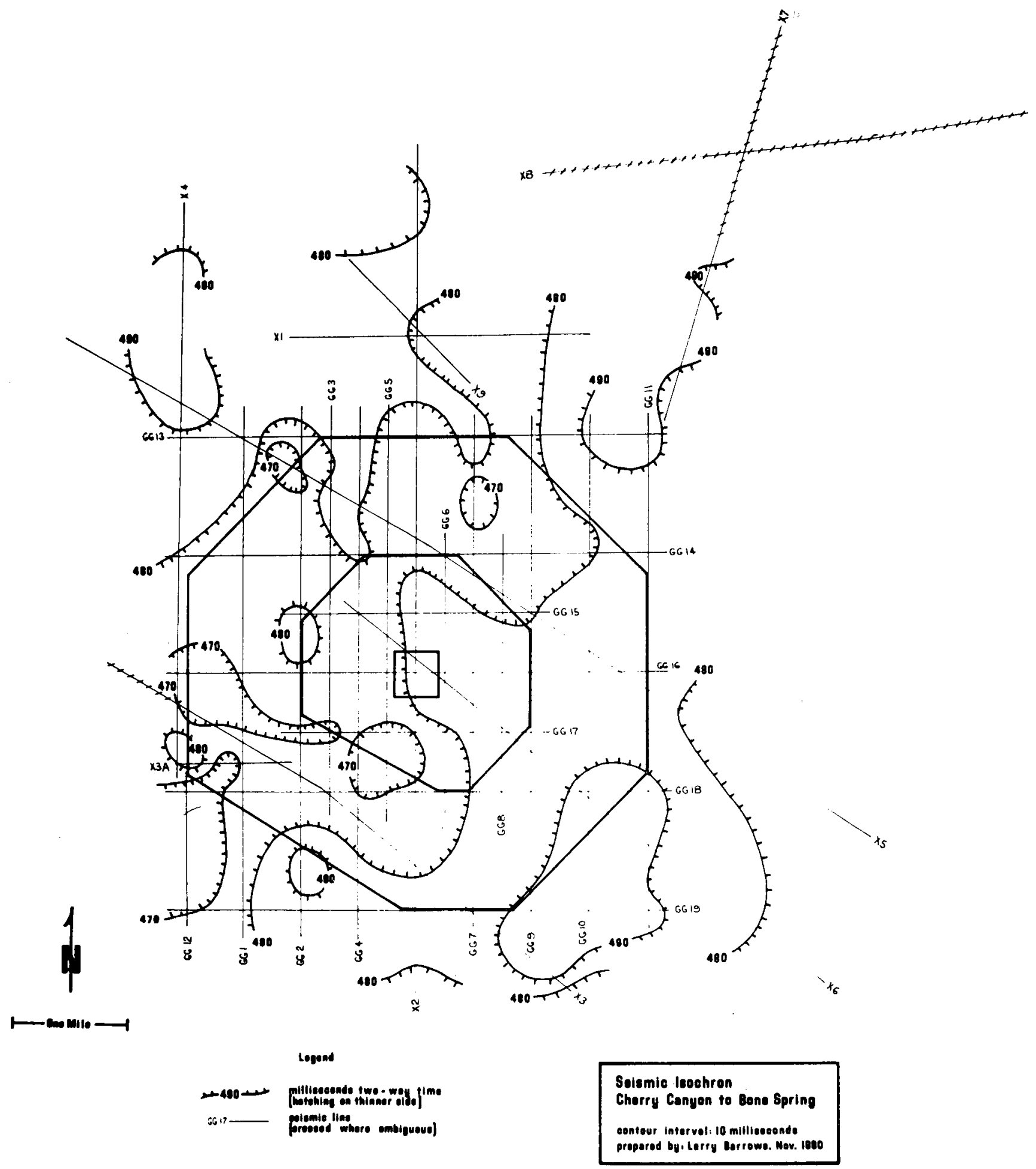

Figure A-8. Seismic Isochron - Cherry Canyon to Bone Spring 


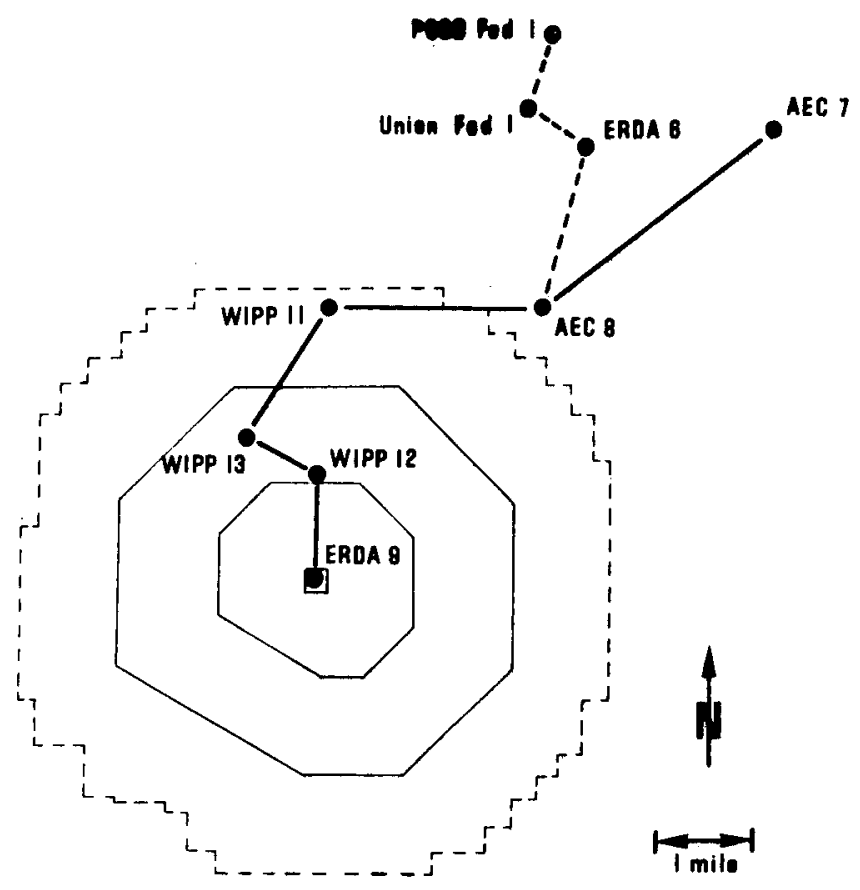

Figure A-9. Boreholes in the DZ That Penetrate the Castile Formation

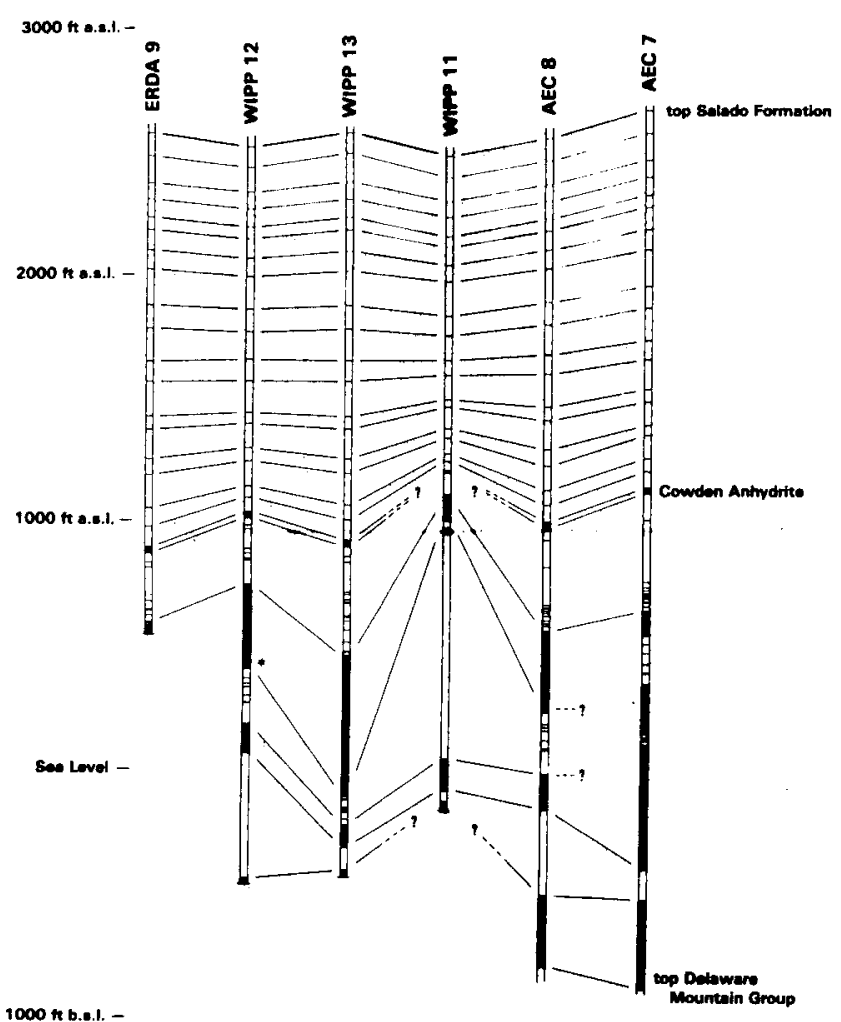

Figure A-10. Salado and Castile Formation Log Correlations in the DZ. (See Figure A-9 for horizontal distribution of holes.)

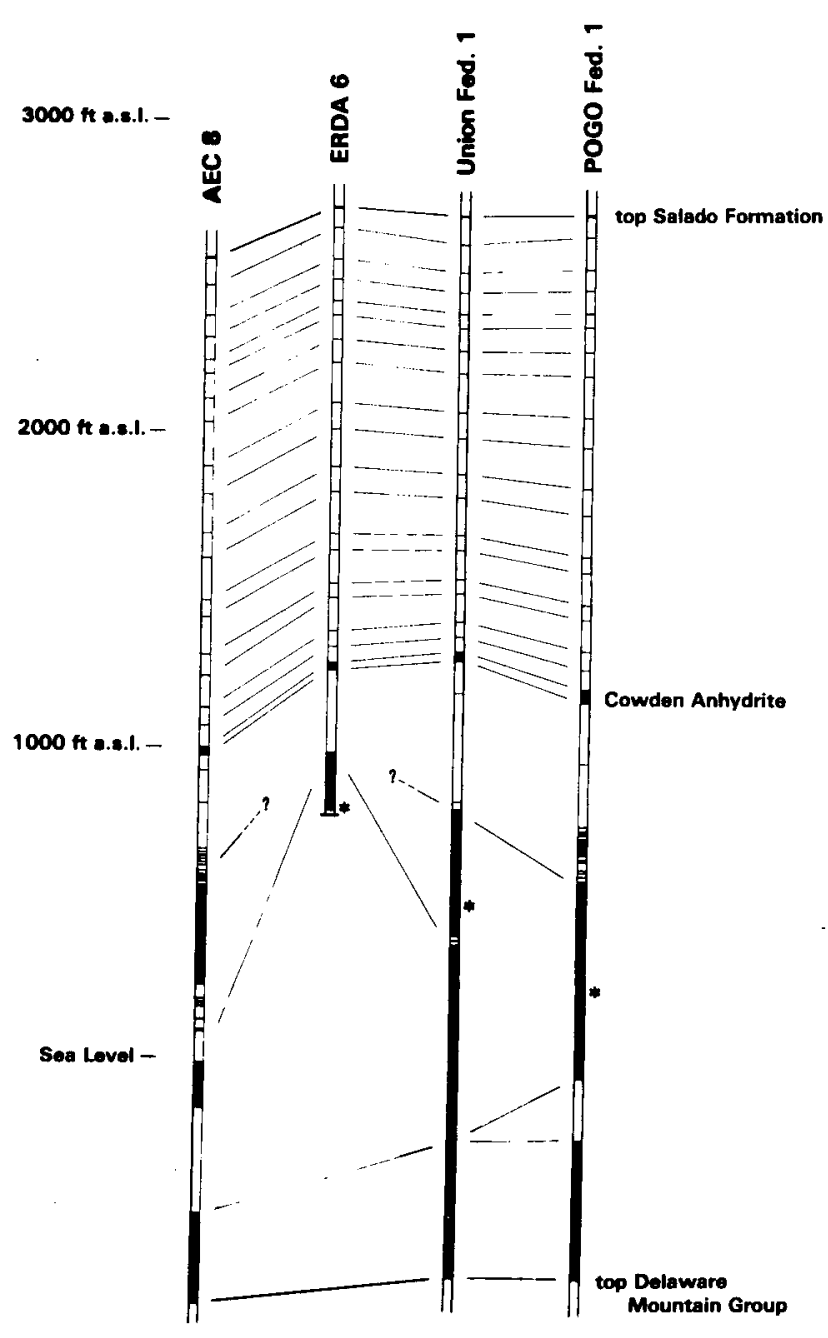

$1000 \mathrm{tt}$ b.s.l. -

Figure A-11. Salado and Castile Formation Log Correlations in the DZ. (see Figure A-9 for horizontal distribution of holes.) 


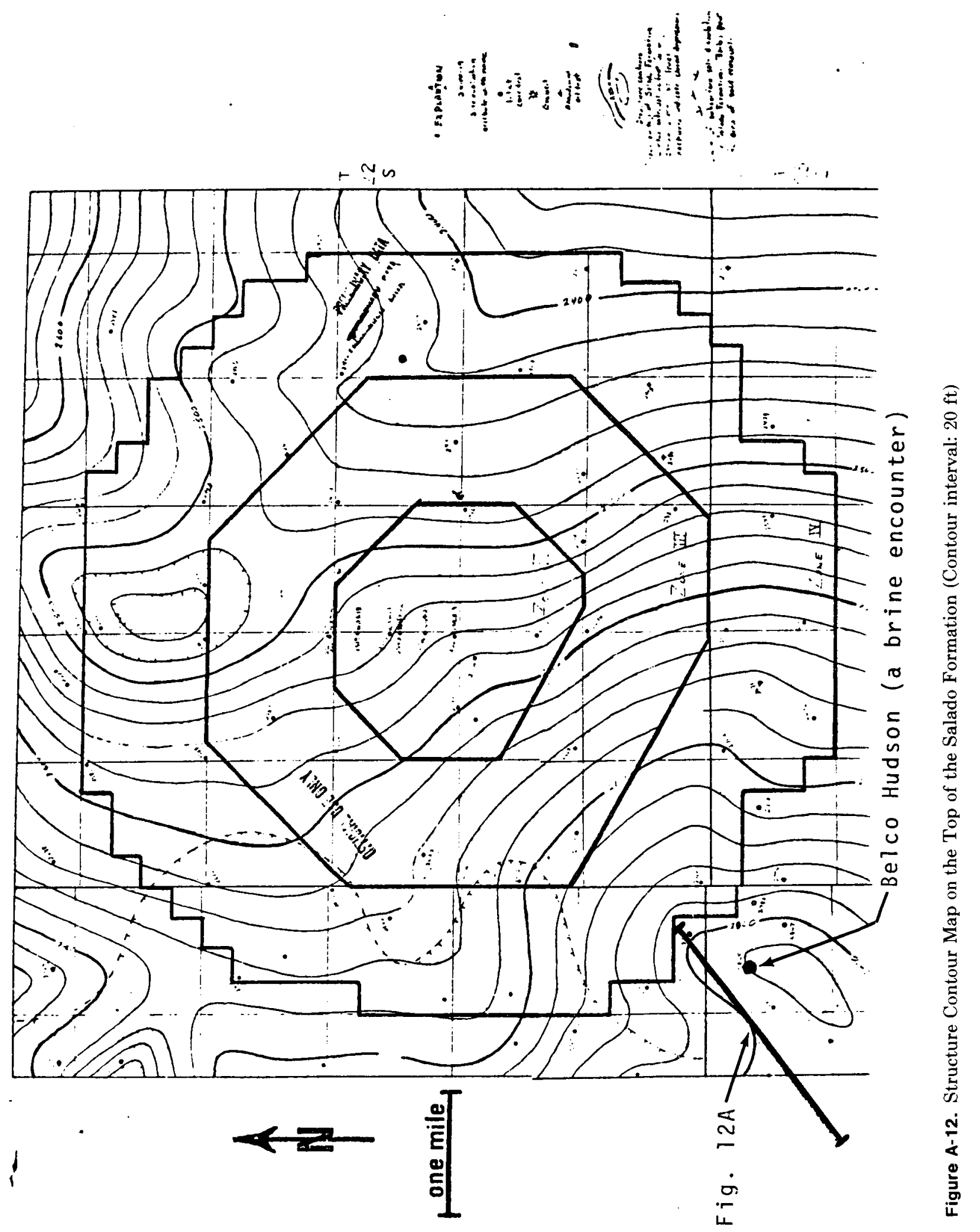




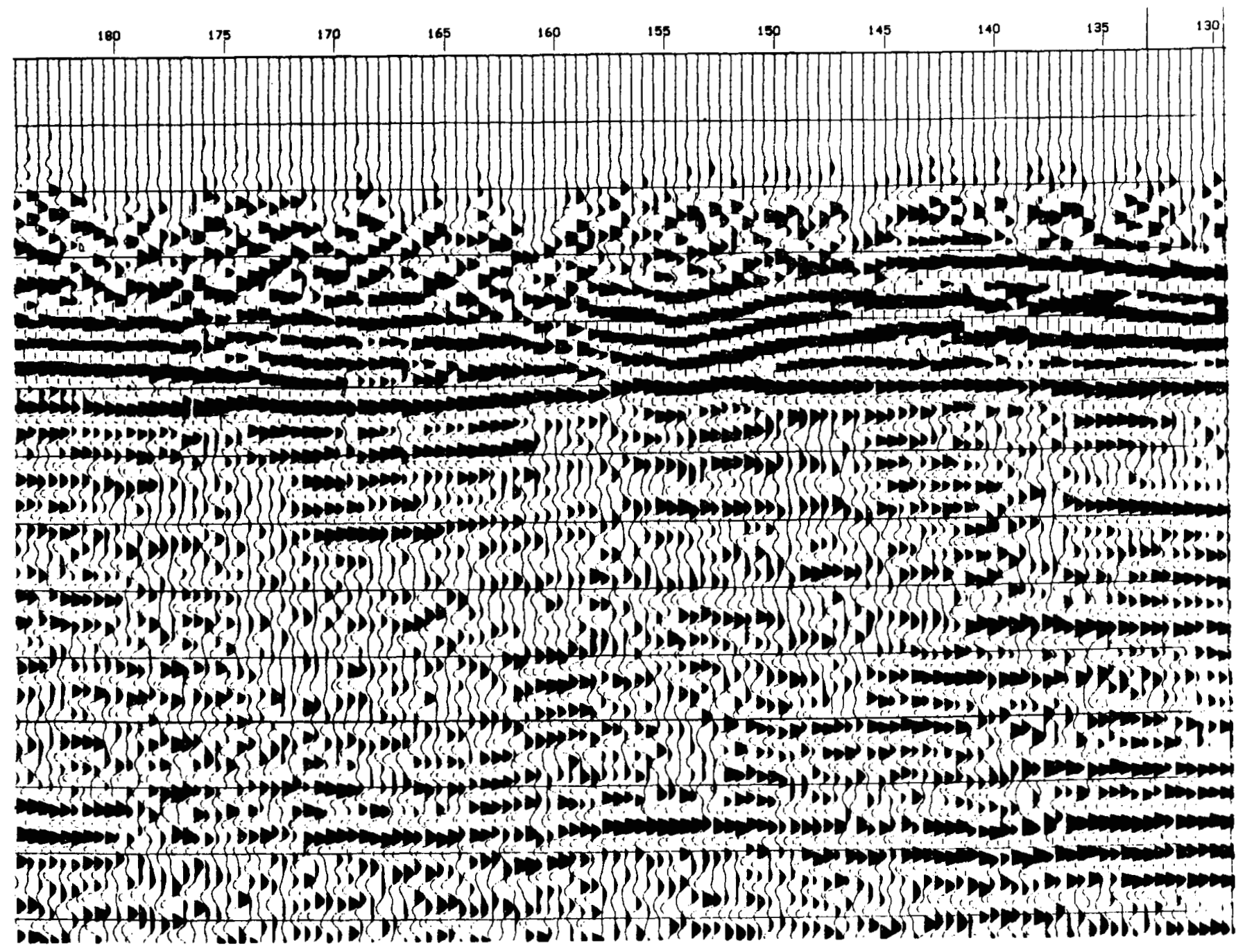

Figure A-13. The Portion of Seismic Line 76SAN2 Indicated on Figure A-12 (The complex structures in the Castile Formation are loosely coincident with the anticline on the top of the Salado Formation.) 


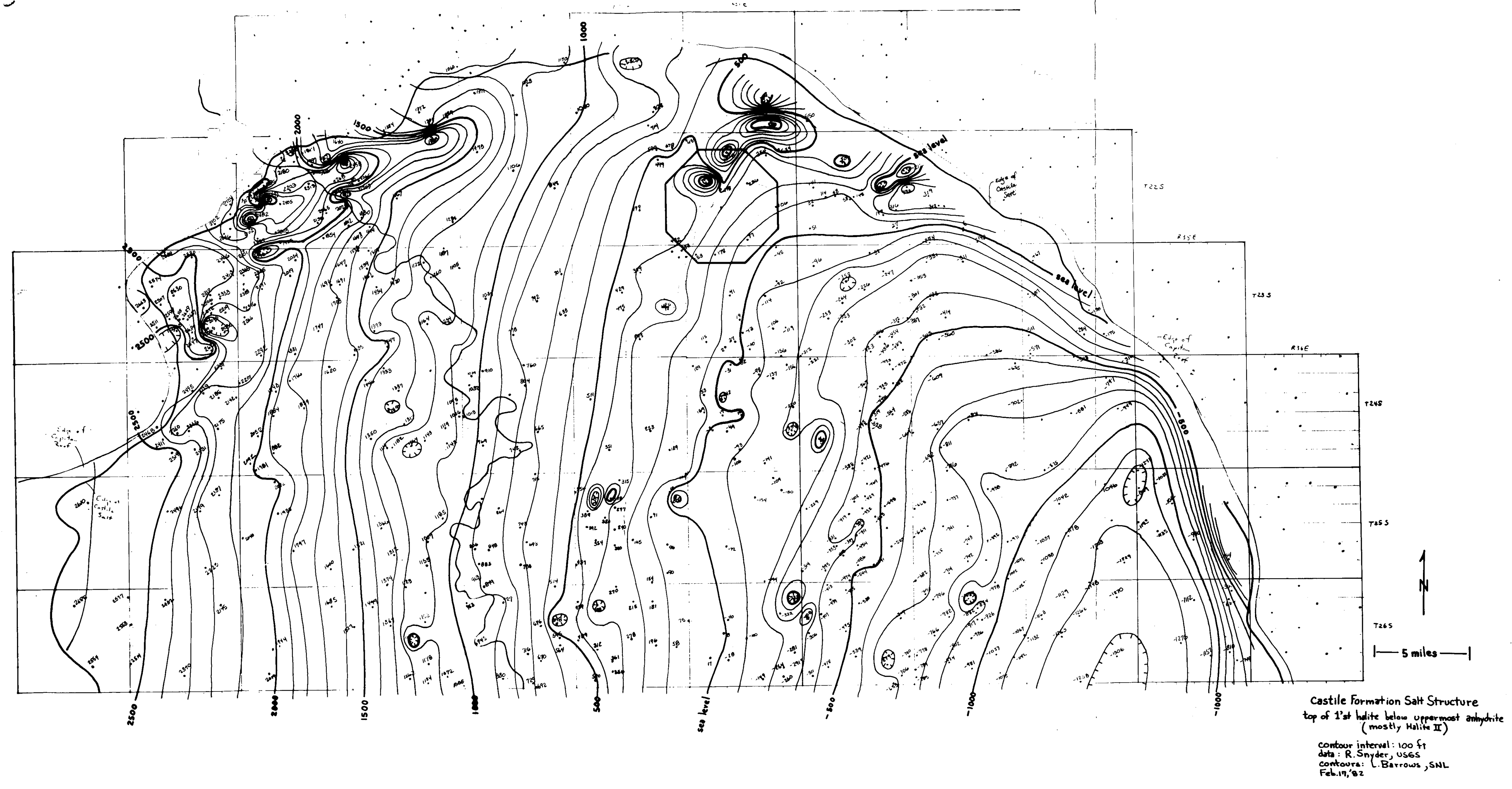


Documented petrographic studies of cores from the $\mathrm{DZ}$ are few and limited. R. Y. Anderson (1976) investigated cores from ERDA 6, AEC 7, and AEC 8 to establish the stratigraphic relations between these holes. The ERDA 6 core from 2551 to $2733 \mathrm{ft}$ was examined in detail. This work showed that the anhydrite unit in ERDA 6 correlated with the Anhydrite II member of the Castile Formation. The core in ERDA 6 had two solution zones and a corroded zone also showing some evidence of solution activity. Lamination dips were commonly greater than $50^{\circ}$ to $60^{\circ}$, and many of the lamina had parted with the intervening voids filled with calcium sulfate. These "extension fractures" postdate microfolding in the Castile Formation. Kirkland and Anderson (1970) have argued from other data that the microfolding developed during the Tertiary.

More recent petrographic studies of core from borehole WIPP 13 by D. Borns (pers. comm., 1-8-82) have indicated complex polyphase deformation facilitated by grain boundary solution/deposition. The suggestion is made that irregular distribution of water may influence development of the deformation.

\section{Mechanisms}

The data base on the $\mathrm{DZ}$ is extensive and provides fairly good control on the structural style. The process and timing of deformation are less well controlled and remain ambiguous. Nevertheless, any feasible process or mechanism must be consistent with the observations, and inconsistent mechanisms can be discarded. All mechanisms that are consistent with the observations should be regarded as feasible. In many practical problems, including the dynamic structural evolution of the DZ, this leads to a variety of possible mechanisms. The method of multiple working hypotheses (Chamberlin, 1890) should be used in evaluating the data and in planning subsequent investigations. For phenomena as complex as the Castile Formation deformations, it is possible that more than one mechanism is involved. However, in the following, the principle of simplicity or Occam's razor (C. A. Anderson, original date unknown; reprinted 1963) is used to select one hypothesis as the more likely. This single hypothesis is expanded in greater detail and accounts for most, if not all, of the observations.

Mechanisms that have been considered include gravity gliding, dissolution, and external tectonics. Gravity gliding is the eastward movement of shallower formations in response to the mid-Cenozoic tilting of the Delaware Basin. It is difficult to reconcile with the isolated location of some disturbed areas (e.g., Poker Lakes), the distribution of the greatest intensity of deformation (i.e., along the northern instead of eastern basin boundary), lack of identifiable decollement surfaces, and the intensity of the deformation. Extensive salt dissolution seems inconsistent with the absence of massive subsidence of overlying material (some disturbed areas are overlain by anticlines), the absence of extensive dissolution residues, and the core descriptions. External tectonics seems inconsistent with the lack of deformation in the underlying Delaware Mountain Group.

At the WIPP site the Castile Formation consists of three massive anhydrite members separated by two halite members. The anhydrite members have a mean density around $2.95 \mathrm{~g} / \mathrm{c}^{3}$ and the halite members around 2.2 to $2.25 \mathrm{~g} / \mathrm{c}^{3}$. Another possible mechanism for the disturbed-zone deformations involves gravitational foundering of the anhydrite through the less dense halite. In this mechanism the gravitationally unstable interfaces between the halite and overlying anhydrite spontaneously deform into alternating (and complementary) halite diapirs and adjacent anhydrite sinks. The overlying and underlying strata are viscously coupled with the deforming interface. The entire process is a form of autonomous, isostatic salt deformation or halokinesis.

The gravity foundering mechanism is further developed in the following sections. It is shown that $\mathrm{DZ}$ deformations are the expected, predictable consequence of the density stratification of the WIPP site along with reasonable estimates of evaporite viscosity.

\section{Analysis}

\section{Theory}

The following material is based on the work of Hans Ramberg at the Institute of Mineralogy and Geology, Uppsala, Sweden. The techniques and their geologic justification are best described in the 1981 edition of his text Gravity, Deformation, and the Earth's Crust.

Gravitational tectonics is a reasonably welldeveloped concept in structural geology. In the broadest sense, deviations from a density-stratified concentric global structure represent increases in gravitational potential energy. Gravitational tectonic stress deforms the material towards the state of lower energy. The effective structures can have the form of lateral density variations such as occur beneath oceanic arc-trench subduction zones and spreading centers. In this case the associated gravitational tectonic stresses form the probable driving force behind plate 
tectonics. Another effective structure is a density inversion such as develops when a layer of salt is buried beneath more dense sediments. In this case, gravitational tectonics lead to the development of salt ridges, pillows, domes, and (ultimately) piercement diapirs.

A more general effective structure involves one or more interfaces across which density decreases with depth. The total system may involve many layers of different densities. There may be a net increase in density with depth through the entire section. Howev$\mathrm{er}$, if one or more of the interfaces between layers has a density inversion, the system is gravitationally unstable. Yield strengths, effective viscosities, layer thicknesses, and densities determine whether and how fast the potential deformation occurs.

The analysis proceeds from the following assumptions:

1. The model consists of a sequence of layers in a uniform gravity field. The layers extend to infinity in the two horizontal directions. Thickness, density, and viscosity are constant within each layer.

2. Materials behave as isotropic Newtonian (linear) viscous fluids. The yield strength is negligible.

3. Inertia is insignificant.

4. Interfaces between layers are continuous. This implies continuity of displacements and stresses.

5. The deformations are sinusoidal waves affecting the entire depth of the model. The amplitude/wavelength ratio is small and the deformations of all interfaces are in phase.
As an introduction to the WIPP analysis, first consider a simple system of two layers sandwiched between a rigid top and bottom (see Figure A-15). The thicknesses, densities, and viscosities are $h_{1}, \rho_{1}, \mu_{1}$, and $h_{2}, \rho_{2}, \mu_{2}$ respectively, and the wavelength of the deformation is $\lambda$.

The deflection of the interface is

$\mathbf{y}=\overline{\mathrm{y}} \sin \omega \mathbf{x}$

where

$\omega=2 \pi / \lambda$

$\lambda=$ the wavelength

The rate of growth of the deflection is

$\mathbf{v}=\mathbf{v} \sin \omega \mathbf{x}$

and (following Ramberg) the associated horizontal rate of growth is

$\mathbf{u}=\overline{\mathbf{u}} \cos \omega \mathbf{x}$

Shear and normal stress at the bottom interface of the upper layer are

$$
\begin{aligned}
\tau_{1} & =2 \mu_{1} \omega\left(\mathrm{S}_{1}^{v} \overline{\mathrm{v}}+\mathrm{S}_{1}^{u} \overline{\mathrm{u}}\right) \cos \omega \mathbf{x} \\
\sigma_{1} & =\frac{2 \mu_{1}}{\mathbf{h}_{1}}\left(\mathrm{P}_{1}^{v} \overline{\mathrm{v}}+\mathrm{P}_{1}^{u} \overline{\mathrm{u}}\right) \sin \omega \mathbf{x} \\
& +\rho_{1} \overline{\mathrm{y}} g \sin \omega \mathbf{x}-\mathrm{p}
\end{aligned}
$$

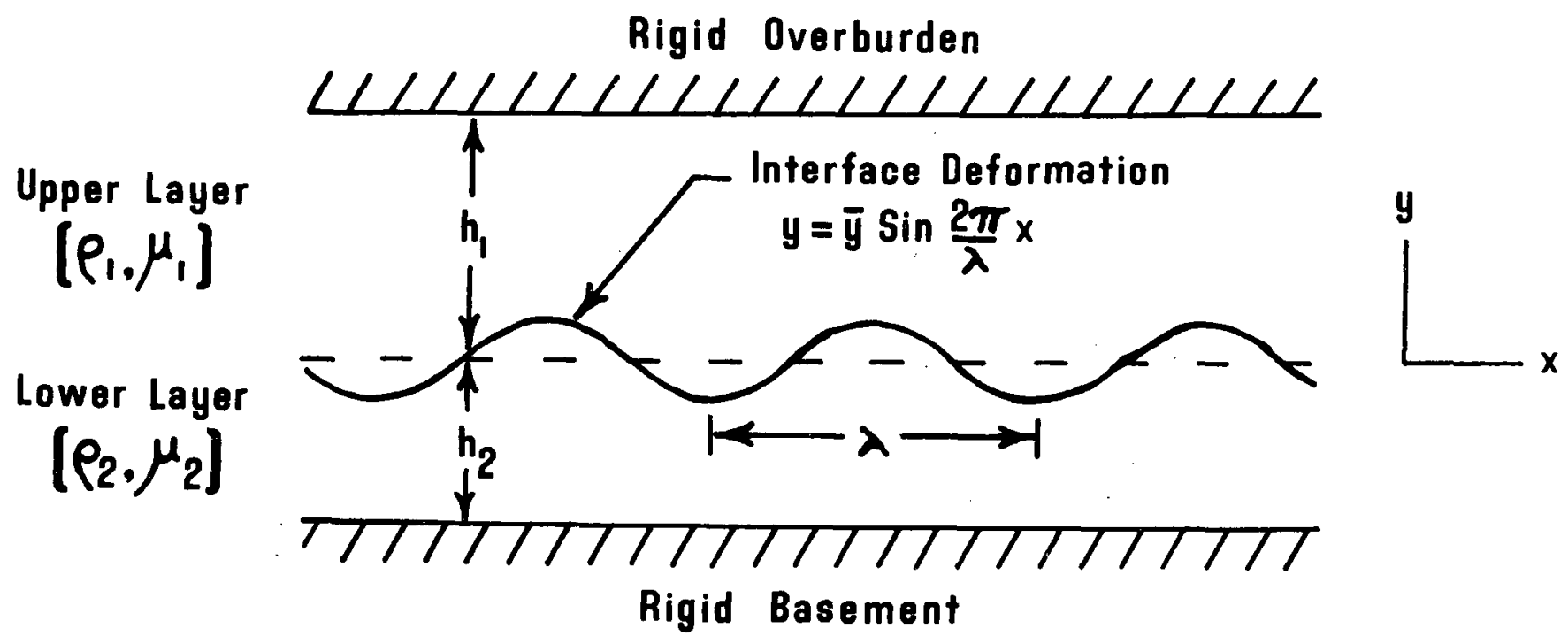

Figure A-15. Simple Two-Layer Model 
And at the top interface of the lower layer

$$
\begin{aligned}
\tau_{2} & =2 \mu_{2} \omega\left(\mathrm{S}_{2}^{\vee} \nabla+\mathrm{S}_{2}^{\mathrm{u}} \overline{\mathrm{u}}\right) \cos \omega \mathbf{x} \\
\sigma_{2} & =\frac{2 \mu_{2}}{\mathrm{~h}_{2}}\left(\mathrm{P}_{2}^{\mathrm{v}} \overline{\mathrm{v}}+\mathrm{P}_{2}^{\mathrm{u}} \overline{\mathrm{u}}\right) \sin \omega \mathrm{X} \\
& +\rho_{2} \overline{\mathrm{y} g} \sin \omega \mathrm{X}-\mathrm{p}
\end{aligned}
$$

where

$\mathrm{p}$ is the mean pressure

$\mathrm{S}, \mathrm{P}$ are constants dependent on the ratio of layer thickness to deformation wavelength

$\mathrm{g}$ is acceleration due to gravity

Continuity of stress yields

$\left[\begin{array}{ll}\mathrm{C}_{11} & \mathrm{C}_{12} \\ \mathrm{C}_{21} & \mathrm{C}_{22}\end{array}\right]\left\{\begin{array}{l}\tilde{\mathrm{v}} \\ \overline{\mathrm{u}}\end{array}\right\}=\left\{\begin{array}{c}\cdot \\ q \bar{y}\end{array}\right\}$

where

$\mathrm{C}_{\mathrm{ij}}$ are constants

$\mathrm{q}=\frac{\left(\rho_{1}-\rho_{2}\right) \mathbf{h}_{2} \mathrm{~g}}{2 \mu_{2}}$

This expression can be inverted to give

$\nabla=\mathrm{kq} \overline{\mathrm{y}}$

where $\mathrm{k}$ is termed the growth factor. The deformation then grows exponentially with time

$\bar{v}=\frac{d \bar{y}}{d t}=k q \bar{y}$

$\bar{y}(t)=\bar{y}_{0} e^{k q t}$

Plots of the growth factor versus wavelength typically show a maximum at some wavelength. This particular wavelength has the fastest rate of growth and, other things being equal, is the deformation wavelength most likely to develop in the system. The rate of growth is predicted by this maximum growth factor.

The multilayer analysis is similar, but now the amplitude and rates of growth of all free interfaces must be considered.
Again, dynamic equilibrium requires continuous normal and shear stress at the interfaces between layers. Material continuity requires continuous displacements and displacement rates. These boundary conditions lead to a set of equations that, for a system with three interfaces, can be written

$\left[\begin{array}{cccccc}\mathrm{C}_{11} & \mathrm{C}_{12} & \mathrm{C}_{13} & \mathrm{C}_{14} & \bullet & \bullet \\ \mathrm{C}_{21} & \mathrm{C}_{22} & \mathrm{C}_{23} & \mathrm{C}_{24} & \bullet & \bullet \\ \mathrm{C}_{31} & \mathrm{C}_{32} & \mathrm{C}_{33} & \mathrm{C}_{34} & \mathrm{C}_{35} & \mathrm{C}_{36} \\ \mathrm{C}_{41} & \mathrm{C}_{42} & \mathrm{C}_{43} & \mathrm{C}_{44} & \mathrm{C}_{45} & \mathrm{C}_{46} \\ \bullet & \bullet & \mathrm{C}_{53} & \mathrm{C}_{54} & \mathrm{C}_{55} & \mathrm{C}_{56} \\ \bullet & \bullet & \mathrm{C}_{63} & \mathrm{C}_{64} & \mathrm{C}_{65} & \mathrm{C}_{66}\end{array}\right]\left\{\begin{array}{c}\mathrm{v}_{1} \\ \mathrm{u}_{1} \\ \mathrm{v}_{2} \\ \mathrm{u}_{2} \\ \mathrm{v}_{3} \\ \mathrm{u}_{3}\end{array}\right\}=\left\{\begin{array}{c}\cdot \\ \mathrm{q}_{1} \mathrm{y}_{1} \\ \bullet \\ \mathrm{q}_{2} \mathrm{y}_{2} \\ \bullet \\ \mathrm{q}_{3} \mathrm{y}_{3}\end{array}\right\}$

where

$\mathrm{y}_{\mathrm{i}}, \mathrm{v}_{\mathrm{i}}, \mathrm{u}_{\mathrm{i}}$ are the displacement and displacement rates of the i'th interface

$C_{i j}, q_{i}$ are constants dependent on the thicknesses, densities, and viscosities of the layers and on the wavelength of the deformation.

This matrix expression can be expanded for systems with more than three interfaces.

The preceding expression can be inverted and the terms rearranged to give

$q_{1}\left[\begin{array}{lll}k_{11} & k_{12} q_{2: 1} & k_{13} q_{3: 1} \\ k_{21} & k_{22} q_{2: 1} & k_{23} q_{3: 1} \\ k_{31} & k_{32} q_{2: 1} & k_{33} q_{3: 1}\end{array}\right]\left\{\begin{array}{l}y_{1} \\ y_{2} \\ y_{3}\end{array}\right\}=\left\{\begin{array}{l}v_{1} \\ v_{2} \\ v_{3}\end{array}\right\}$

where

$q_{i: 1} \triangleq q_{i} \div q_{1}$

The elements of the k-matrix describe how a displacement on one interface affects the displacement rates, or velocities, on all interfaces. The total matrix represents the coupling between the degrees of freedom (displacement rates) and loads (displacements) for the system of layers. For such matrices it is useful to consider the eigenvalues and their associated eigenvectors.

The eigenvalues and eigenvectors are the constants $K_{i} i=1 \ldots n$ and corresponding vectors $\{Y\}_{i} i=$ $1 \ldots \mathrm{n}$, which satisfy

$[\mathrm{k}]\{\mathrm{Y}\}_{\mathrm{i}}=\mathrm{K}_{\mathrm{i}}\{\mathrm{Y}\}_{\mathrm{i}} \quad \mathrm{i}=1 \ldots \mathrm{n}$ 
where $\mathrm{n}$ is the number of interfaces in the system. Multiply by the constant $q_{1}$

$\mathrm{q}_{1}[\mathrm{k}]\{\mathrm{Y}\}_{\mathrm{i}}=\mathrm{q}_{1} \mathrm{~K}_{\mathrm{i}}\{\mathrm{Y}\}_{\mathrm{i}}$

Recall that

$\mathrm{q}_{1}[\mathrm{k}]\{\mathrm{y}\}=\{\mathrm{v}\}$

Then

$\mathrm{q}_{1} \mathrm{~K}_{\mathrm{i}}\{\mathrm{Y}\}_{\mathrm{i}}=\{\mathrm{V}\}_{\mathrm{i}}$

where $\{V\}_{i}$ is the time rate of change of the displacement eigenvector $\{\mathrm{Y}\}_{\mathrm{i}}$.

The eigenvectors are then those particular displacements whose rates of growth throughout the system of layers are proportional to itself. These will be the fastest deformation rates and are the ones most likely to develop. If the displacements are proportional to the eigenvector, then they will grow exponentially at a rate

$\{\mathrm{Y}\}_{\mathrm{i}}=\left\{\mathrm{Y}_{\mathrm{o}}\right\} \mathrm{e}^{\mathbf{q}_{\mathbf{1}} \mathbf{K}_{\mathrm{i}} \mathrm{t}}$

\section{WIPP Models}

The basic WIPP-site density structure is fairly well established (deviations from this basic structure will be the subject of an interpretive report on the gravity survey). Figure A-16 is a copy of the density $\log$ of the Castile Formation in borehole AEC 8. Note that Anhydrite II and Anhydrite III overlie less dense halite members. Figure A-17 is a simplified model of the overall density stratigraphy.
Density inversions occur in four places on the density model (Figure A-17). These are the Rustler/ Salado contact, and the bases of Anhydrite III, Anhydrite II, and Anhydrite I. Each of these interfaces is gravitationally unstable and would spontaneously deform if the material were soft enough.

Seismic and borehole information indicates that DZ deformations do not extend below the top of the Delaware Mountain Group. This is reasonably attributed to the stronger, or less viscous, character of clastic and carbonate sediments in the Delaware Mountain Group. For the model analysis, the top of the Delaware Mountain Group is assumed to form a rigid basement.

The Salado Formation was divided by an inactive interface at $2100 \mathrm{ft}$ to determine the deformation effects at the repository horizon. Densities and viscosities were constant across this interface.

The WIPP density model then has eight free interfaces. The associated k-matrix has eight eigenvalue - eigenvector pairs, each of which can be related to a particular interface by inspection of the eigenvectors. The four pairs related to interfaces with stable density contrasts (density increases with depth) have positive eigenvalues and, along with the negative $q_{1}$, describe an exponentially decaying or flattening deformation. The one pair associated with the repository horizon has a zero eigenvalue indicating no growth. This results from the lack of any density contrast across this interface. The three pairs that relate to unstable density contrasts have negative eigenvalues indicating deformations that grow exponentially with time. These deformation modes will be examined in greater detail.

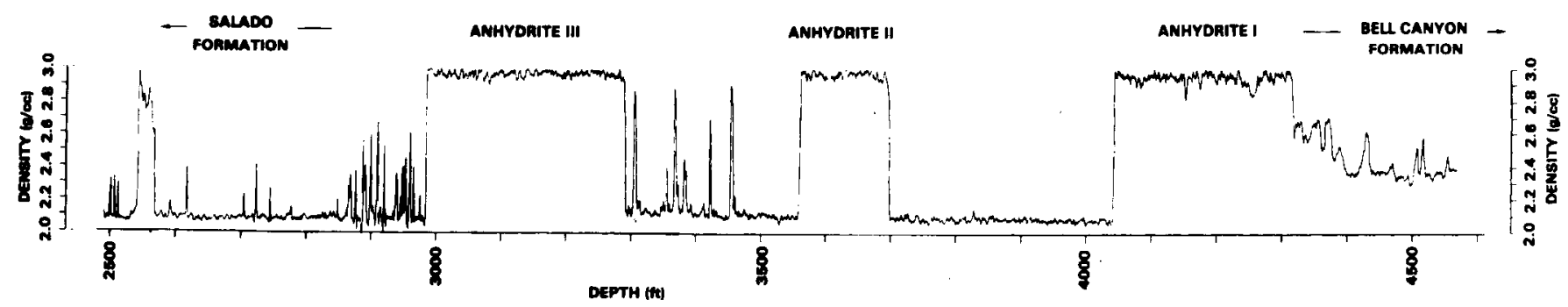

Figure A-16. Densilog of the Castile Formation in Borehole AEC 8 (The three massive anhydrite members are clearly distinguished from the less dense halite.) 


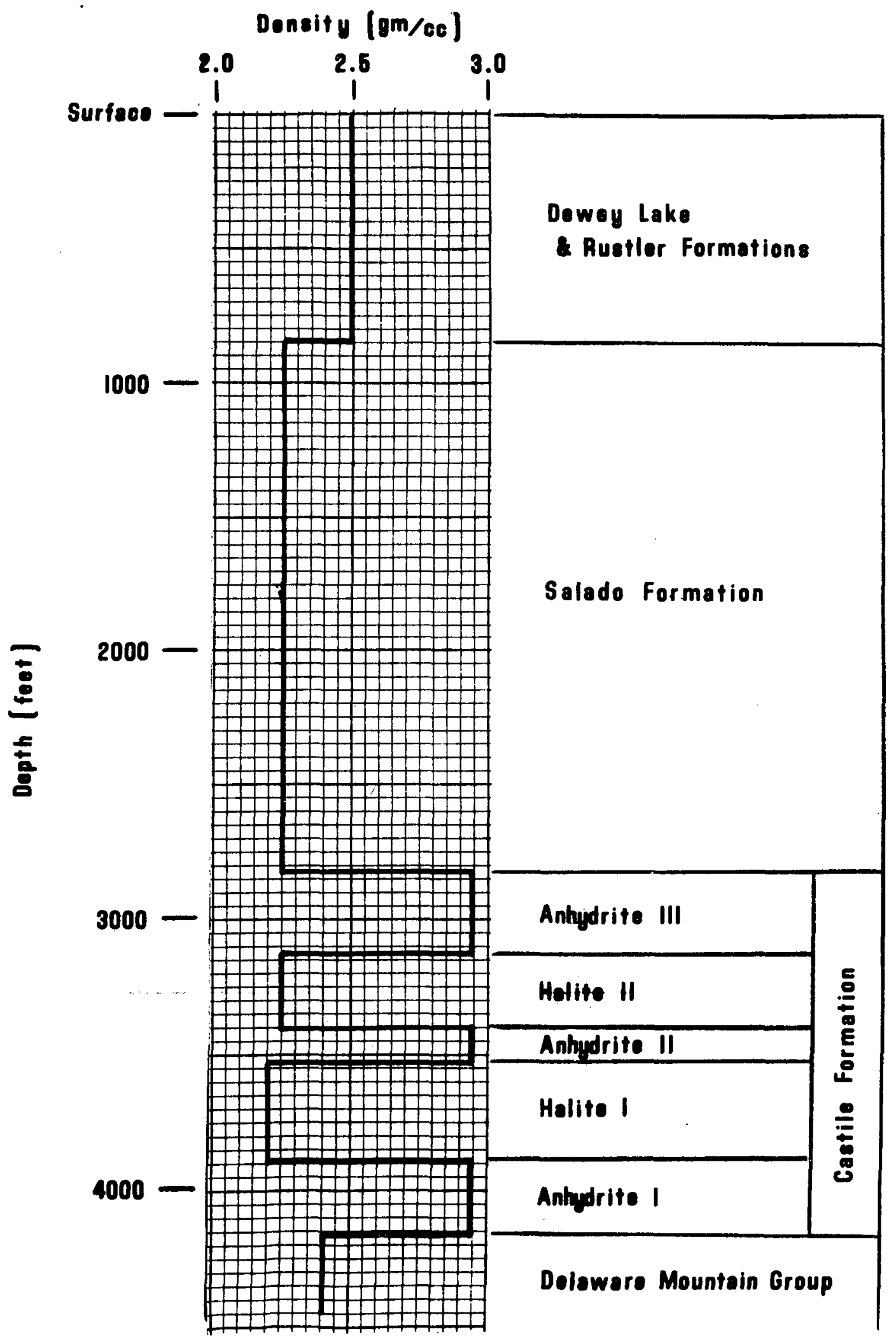

Figure A-17. WIPP Site Generalized Density Structure (These densities and thicknesses are used in the two dynamic models.) 
The equations relating normal and shear stresses to deformation rates depend on the wavelength of the deformation. This dependency carries through the analysis of a system of layers; the eigenvalues also depend on the wavelength of the deformation. Plots of the eigenvalues versus wavelength show a maximum for each of the three unstable modes of deformation. These maxima are at the fastest growing deformation wavelengths; these wavelengths are thus the most likely to develop.

At the WIPP site, rock densities and layer thicknesses are fairly well established by borehole and well$\log$ data. Effective viscosities are much less controlled and are considered a variable in the analysis. Fortunately the analysis depends on the contrasts in relative viscosity between layers. The absolute viscosities are left out of the analysis until a final calculation of the exponential growth rate.

Two models were analyzed, both with identical layer densities and thicknesses but dissimilar viscosities. The first model assumes a constant (but unspecified) viscosity throughout the entire section. The resulting plot of the three growth eigenvalues (for the three unstable density interfaces) is shown in Figure A-18. The numerical values are given in Table A-1.

Figure A-18 indicates deformation wavelengths of $150 \mathrm{~m}$ on the interface between Anhydrite II and Halite I, $300 \mathrm{~m}$ on the interface between Anhydrite III and Halite II, and $900 \mathrm{~m}$ on the interface between the Rustler and Salado Formations. The corresponding eigenvectors are given in Table A-2.

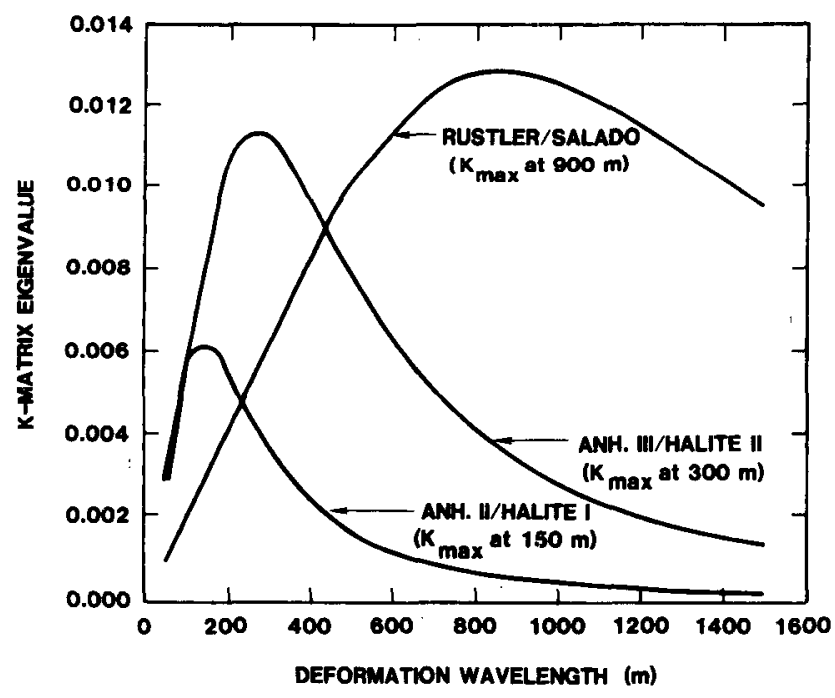

Figure A-18. Growth Factors or k-Matrix Eigenvalues for the Three Gravitationally Unstable Interfaces - Model 1

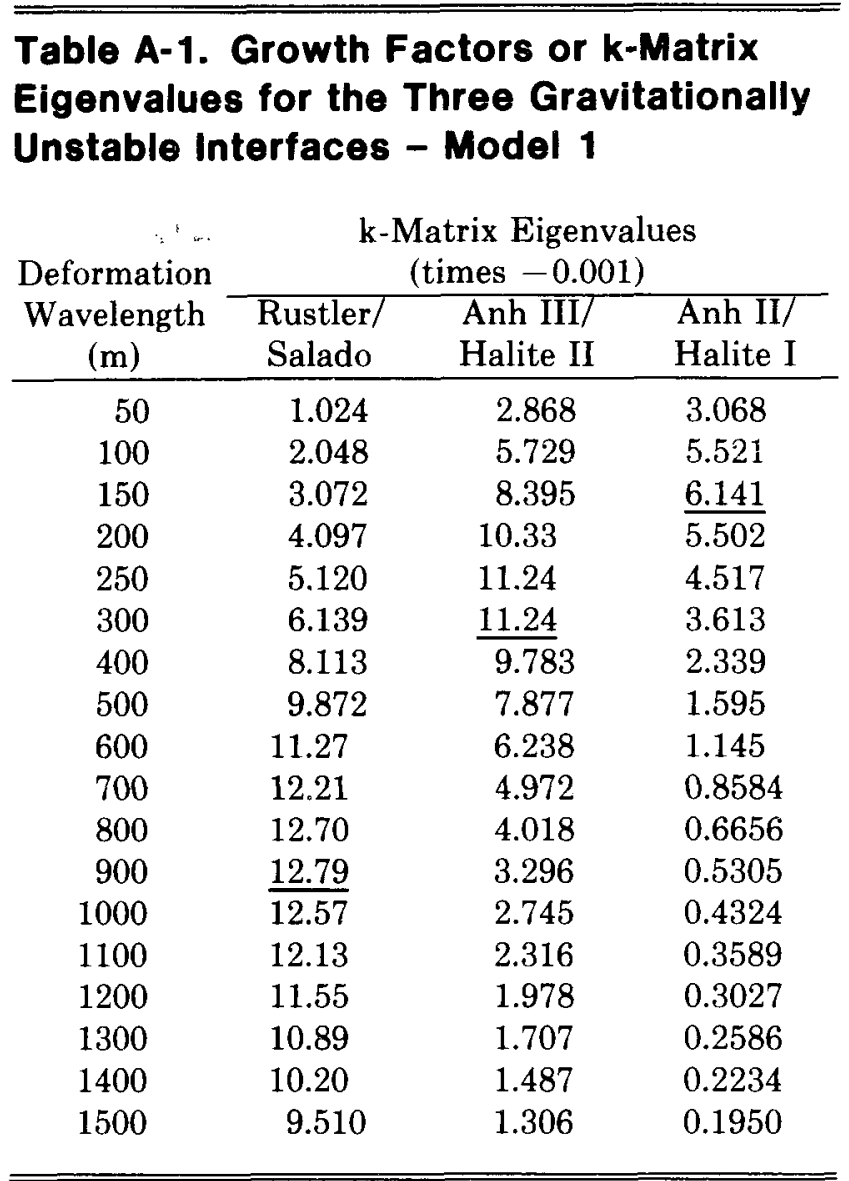

Table A-2. Normalized Eigenvector Components at the Wavelengths of Maximum Rate of Growth for the Three Gravitationally Unstable Interfaces Model 1

\begin{tabular}{|c|c|c|c|}
\hline \multirow[b]{2}{*}{ Interface } & \multicolumn{3}{|c|}{ Eigenvector Components } \\
\hline & $\begin{array}{c}\text { Rustler/ } \\
\text { Salado } \\
\end{array}$ & $\begin{array}{l}\text { Anh III/ } \\
\text { Halite II }\end{array}$ & $\begin{array}{l}\text { Anh II/ } \\
\text { Halite I }\end{array}$ \\
\hline Free surface & 0.024 & $*$ & $*$ \\
\hline Rustler/Salado & 1.000 & * & * \\
\hline Repository & 0.165 & -0.005 & * \\
\hline Salado/Anh III & 0.006 & 0.140 & 0.001 \\
\hline Anh III/Halite II & -0.002 & 1.000 & 0.032 \\
\hline Halite II/Anh II & $*$ & 0.152 & 0.159 \\
\hline Anh II/Halite I & * & -0.011 & 1.000 \\
\hline Halite I/Anh I & $*$ & -0.005 & 0.020 \\
\hline
\end{tabular}


The first eigenvector in Table A-2 is for deformations primarily related to the density contrast across the Rustler/Salado interface. The deformation amplitude on the free surface should be about $2 \%$ of that on the Rustler/Salado interface. The deformation amplitude at the repository level should be about $16 \%$ of this interface, and the other interfaces should be essentially undeformed.

The second and third eigenvectors in Table A-2 are for deformations related to density inversions within the Castile Formation. The deformation amplitudes on adjacent interfaces are about $15 \%$ of those on the gravitationally unstable interfaces.

The eigenvectors show that the gravity-foundering mechanism should affect primarily the Castile Formation and the Rustler/Salado interface. The free surface and intervening Salado Formation are expected to show only minimal effects. From the plot of eigenvalues versus deformation wavelength, the expected wavelength at the Rustler/Salado contact is several times the wavelengths expected in the Castile Formation. Interestingly, the wavelengths are integer multiples of each other. This characteristic should be expected in a dynamically coupled system.

A shortcoming of the constant-viscosity model is that it predicts relatively large deformations on the Rustler/Salado interface, while the observed deformations are finite but small. The second model analyzed was identical to the first except that the viscosity of the first layer (Dewey Lake and Rustler Formations) was ten times that of the underlying layers (Salado and Castile Formations). This change seems justified; the first layer is primarily clastic sediments and the lower layers are evaporites.

For the second model, Figure A-19 is a plot of the three growth eigenvalues (for the three unstable density interfaces) versus the wavelength of the deformation (Table A-3 contains the numerical values). The corresponding eigenvectors are given in Table A-4. These results are very similar to those of the first model. The model predicts deformation wavelengths of $140 \mathrm{~m}$ on the interface between Anhydrite II and Halite I, $280 \mathrm{~m}$ on the interface between Anhydrite III and Halite II, and $800 \mathrm{~m}$ on the Rustler/Salado interface. The eigenvectors predict minimal surface and mid-Salado (i.e., repository-level) deformation.

\section{Table A-3. Growth Factors or k-Matrix Elgenvalues for the Three Gravitationally Unstable Interfaces - Model 2}

\begin{tabular}{cccc} 
& \multicolumn{3}{c}{ k-Matrix Eigenvalues } \\
Deformation & \multicolumn{3}{c}{ (times -0.01) } \\
\cline { 2 - 4 } $\begin{array}{c}\text { Wavelength } \\
\text { (m) }\end{array}$ & $\begin{array}{c}\text { Rustler/ } \\
\text { Salado }\end{array}$ & $\begin{array}{c}\text { Anh III/ } \\
\text { Halite II }\end{array}$ & $\begin{array}{c}\text { Anh II/ } \\
\text { Halite I }\end{array}$ \\
\hline 20 & 0.05852 & 1.147 & 1.229 \\
40 & 0.1170 & 2.294 & 2.458 \\
60 & 0.1756 & 3.441 & 3.662 \\
80 & 0.2341 & 4.588 & 4.728 \\
100 & 0.2926 & 5.729 & 5.521 \\
120 & 0.3511 & 6.845 & 5.988 \\
140 & 0.4097 & 7.902 & $\underline{6.153}$ \\
160 & 0.4682 & 8.857 & 6.079 \\
180 & 0.5267 & 9.676 & 5.840 \\
200 & 0.5852 & 10.33 & 5.502 \\
220 & 0.6437 & 10.82 & 5.115 \\
240 & 0.7022 & 11.14 & 4.715 \\
260 & 0.7605 & 11.30 & 4.324 \\
280 & 0.8187 & $\underline{11.33}$ & 3.954 \\
300 & 0.8766 & 11.24 & 3.613 \\
320 & 0.9340 & 11.06 & 3.302 \\
340 & 0.9907 & 10.81 & 3.021 \\
360 & 1.046 & 10.50 & 2.769 \\
380 & 1.101 & 10.15 & 2.542 \\
400 & 1.154 & 9.783 & 2.339 \\
420 & 1.206 & 9.401 & 2.157 \\
440 & 1.256 & 9.013 & 1.994 \\
460 & 1.303 & 8.626 & 1.847 \\
480 & 1.348 & 8.247 & 1.714 \\
500 & 1.391 & 7.877 & 1.595 \\
600 & 1.560 & 6.238 & 1.145 \\
700 & 1.653 & 4.972 & 0.8584 \\
800 & $\underline{1.678}$ & 4.018 & 0.6656 \\
900 & 1.652 & 3.296 & 0.5305 \\
1000 & 1.591 & 2.745 & 0.4324 \\
1100 & 1.510 & 2.316 & 0.3589 \\
1200 & 1.418 & 1.978 & 0.3027 \\
1300 & 1.324 & 1.707 & 0.2586 \\
1400 & 1.231 & 1.487 & 0.2234 \\
1500 & 1.142 & 1.306 & 0.1950 \\
\hline & & & \\
\hline
\end{tabular}


Table A-4. Normalized Eigenvector Components at the Wavelengths of Maximum Rate of Growth for the Three Gravitationally Unstable Interfaces Model 2

\begin{tabular}{lccc} 
& \multicolumn{3}{c}{ Eigenvector Components } \\
\cline { 2 - 4 } \multicolumn{1}{c}{ Interface } & $\begin{array}{c}\text { Rustler/ } \\
\text { Salado }\end{array}$ & $\begin{array}{c}\text { Anh III/ } \\
\text { Halite II }\end{array}$ & $\begin{array}{c}\text { Anh II/ } \\
\text { Halite I }\end{array}$ \\
\hline Free surface & 0.027 & $*$ & $*$ \\
Rustler/Salado & 1.000 & $*$ & $*$ \\
Repository & 0.134 & -0.004 & $*$ \\
Salado/Anh III & 0.001 & 0.128 & 0.001 \\
Anh III/Halite II & 0.001 & 1.000 & 0.032 \\
Halite II/Anh II & $*$ & 0.142 & 0.148 \\
Anh II/Halite I & $*$ & -0.012 & 1.000 \\
Halite I/Anh I & $*$ & -0.004 & 0.016 \\
\hline \hline
\end{tabular}

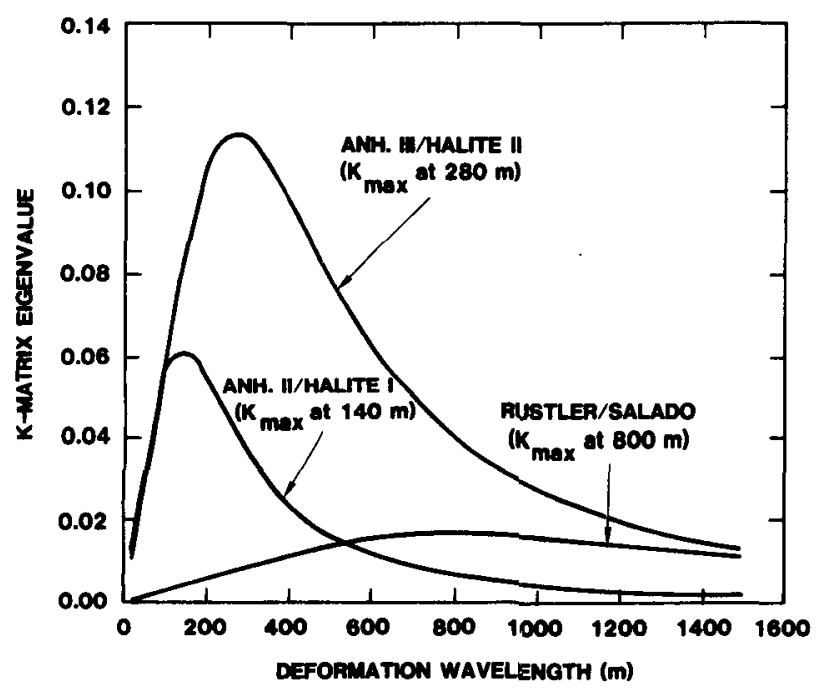

Figure A-19. Growth Factors or k-Matrix Eigenvalues for the Three Gravitationally Unstable Interfaces - Model 2
The primary difference between the results of the first and second model analysis is the relative rates of growth on the Rustler/Salado interface. In the first model the maximum growth factor, or eigenvalue, at the Rustler/Salado interface is larger than the maximum growth factors of the two unstable interfaces within the Castile Formation. This model "predicts" large deformations on the Rustler/Salado interface. In the second model, the maximum growth factor at the Rustler/Salado interface is much less than the growth factors of the two unstable interfaces within the Castile Formations. This model "predicts" relatively small (and long-wavelength) deformations at this interface. Apparently the relative rates of growth can be adjusted by carefully selecting the relative viscosities.

Model results are shown diagrammatically in Figure A-20. The wavelengths and relative amplitudes are those predicted by the second model, except that the deformation amplitude on the Rustler/Salado interface is intermediate between the two models. The effects of the three unstable density interfaces on all other interfaces are those given by the corresponding eigenvectors.

\section{Rates of Growth}

The rate of growth can be expressed as the time required for the deformation to grow $\mathrm{e}=2.72$ times the initial amplitude, or

$\mathrm{t}=\frac{1}{\mathrm{q}_{1} \mathrm{~K}_{\max }}$

where

$\mathrm{q}_{1}=\frac{-\rho_{2} \mathrm{gh}}{2 \mu_{2}}$

$\rho_{2}=2.5 \mathrm{~g} / \mathrm{c}^{3}$, density of the upper layer

$\mathrm{g}=980 \mathrm{~cm} / \mathrm{s}^{2}$, acceleration due to gravity

$\mathrm{h}=850 \mathrm{ft}=25900 \mathrm{~cm}$, thickness of the upper layer

$\mathrm{M}_{2}=$ viscosity of the upper layer

$\mathrm{K}_{\max }$ is the eigenvalue, or growth factor, corresponding to the wavelength of maximum growth for the particular interface considered. In the second WIPP model the interface between Anhydrite III and Halite II has a maximum eigenvalue of 0.113 . 


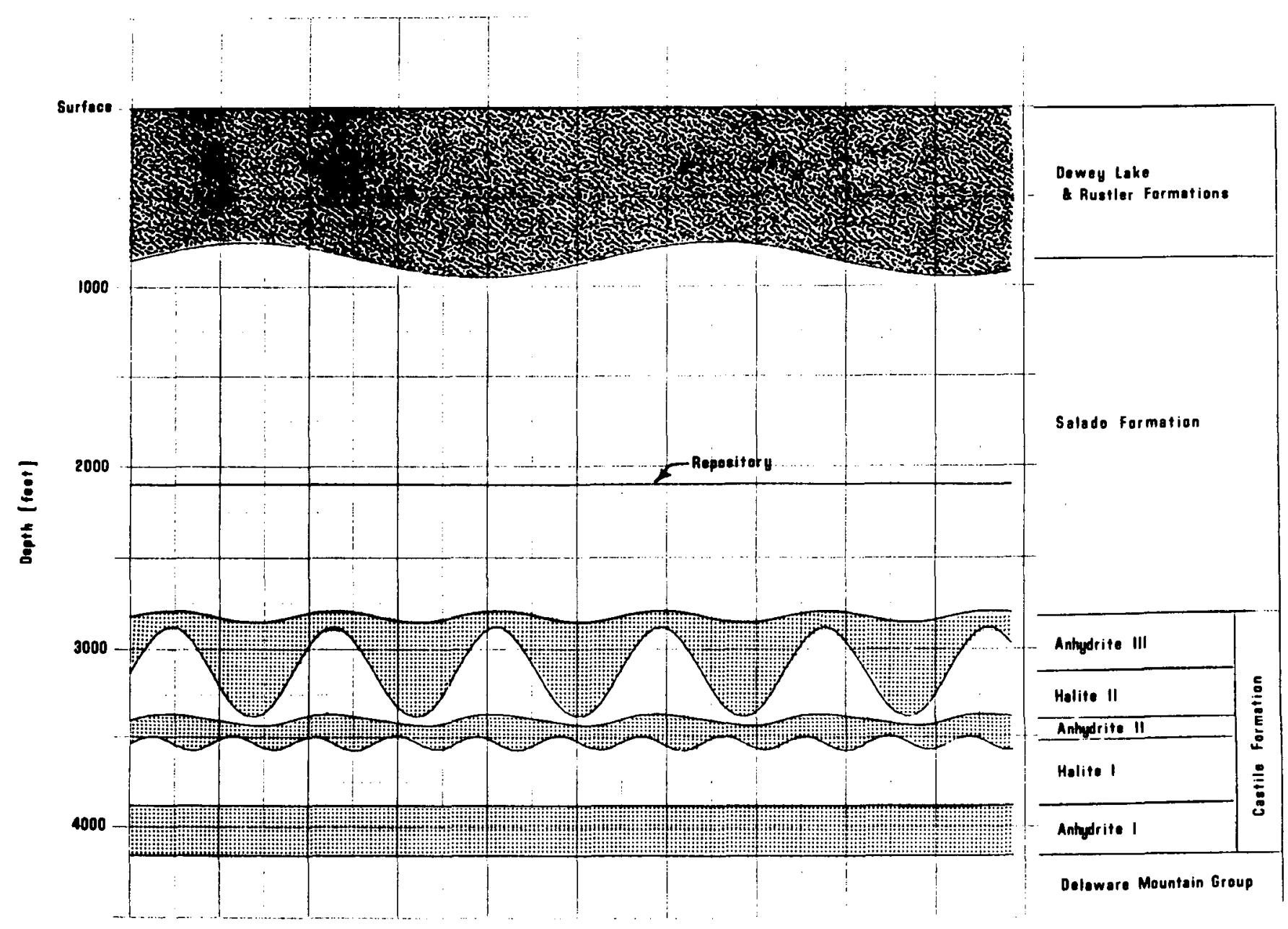

Figure A-20. Diagrammatic Presentation of the WIPP Dynamic Analysis (Deformation wavelengths and the effect on adjacent beds are predicted by the appropriate eigenvalue/eigenvector pairs. Amplitude on the Rustler/Salado interface is arbitrarily selected.)

From the preceding relations, the characteristic time is directly proportional to the viscosity of the upper layer in the model. In the second WIPP model the viscosity of this upper layer (the Dewey Lake and Rustler Formations) was assumed to be ten times that of the underlying layers (Salado and Castile Formations). Thus, assigning a value to the upper layer determines the viscosities throughout the entire model.

The effective viscosity of large volumes of heterogeneous evaporites under the actual conditions of temperature, pressure, strain rate, and water content that exist during deformation is unknown. In relating both theoretical analysis and centrifuge models to geologically reasonable growth rates of salt diapirs, Ramberg ( $\mathrm{p} 97$ and Chap 12) adopted $10^{18} \mathrm{P}$ as a salt viscosity. Other authors have used different values.

Table A-5 shows the characteristic times for evaporite viscosities of $10^{17}, 10^{18}, 10^{19} \mathrm{P}$.

The rate of growth can also be approximated by the velocity of deformation when the amplitude of the waves is an arbitrary percentage of the wavelength (say $10 \%$ ). For deformations on the interface between Anhydrite III and Halite II (Table A-5), the wavelength of maximum growth is $280 \mathrm{~m}$. Waves with an amplitude equal to $10 \%$ of this wavelength will grow by an amount of $28 \times(e-1)$ in one characteristic time. The resulting velocities are included in Table A-5. 
Table A-5. Deformation Rates at the Interface Between Anhydrite III and Halite II (see text for details)

\begin{tabular}{|c|c|c|c|}
\hline \multicolumn{2}{|c|}{ Effective Viscosity (P) } & \multirow[b]{2}{*}{$\begin{array}{c}\text { Time } \\
(\mathrm{yr})\end{array}$} & \multirow[b]{2}{*}{$\begin{array}{l}\text { Velocity } \\
(\mathrm{cm} / \mathrm{yr})\end{array}$} \\
\hline $\begin{array}{l}\text { Dewey Lake } \\
\text { and Rustler } \\
\text { Formations }\end{array}$ & $\begin{array}{l}\text { Salado and } \\
\text { Castile } \\
\text { Formations }\end{array}$ & & \\
\hline $10^{18}$ & $10^{17}$ & 8943 & 0.538 \\
\hline $10^{19}$ & $10^{18}$ & 89430 & 0.054 \\
\hline $10^{20}$ & $10^{19}$ & 894301 & 0.005 \\
\hline
\end{tabular}

\section{Centrifuge Models}

\section{Gravitational Foundering}

The analysis successfully accommodates a shortwavelength deformation within the Castile Formation; longer wavelength with less intense deformation at the Rustler/Salado interface; little or no deformation at the free surface, at the repository horizon, and in the underlying Delaware Mountain Group. The mechanics of gravity foundering, rates of deformation, and evaporite viscosities are reasonably consistent with the observations if a finite yield strength is assumed to retard deformation in the normal areas.

The analysis is limited to low-amplitude sinusoidal deformations in a system of infinite layers. The boreholes, however, encounter vertical displacements of hundreds of feet, strains of hundreds of percent, missing and duplicated units, lamina dips of flat through vertical (locally overturned?), solution/ recrystallization and possible faults. Clearly the $\mathrm{DZ}$ is more complex than the case analyzed.

Gravity foundering will ultimately move the more dense material beneath the less dense. Centrifuge models demonstrate the resulting structural complexity of this process. Such models are significant because, if they are properly constructed, the model will pass through a structural evolution similar to the geologic prototype. The suitability of the centrifuge technique, the interplay between scaling ratios, and the laboratory procedures are discussed in detail in Ramberg's text (Chap 1 and 10 of the 1981 edition).

In a normal gravity field, gravitational tectonic models are difficult to construct because properly scaled materials are too soft for convenient handling.
A corollary is that large rock masses deform as very soft or low-viscosity fluids over the extended duration of geologic time. The centrifuge technique replaces the normal gravity field with very strong (2000 to $3000 \mathrm{~g}$ ) centrifugal body forces. Various clays and putties then possess reasonably scaled properties for use in gravitational tectonic models.

The following models are taken from Chap 15 of Ramberg's text. 'They were originally intended to demonstrate gravitational deformations within an orogenic belt. However, if the scale ratios are redefined, the same models demonstrate gravity foundering of dense anhydrite through less dense halite.

The models were constructed from layers of painter's putty, silicone putty, and an oil-wax mixture in circular pans $10 \mathrm{~cm}$ in diameter. The density and viscosity of the layers differ, and the configurations of the layers vary between models. Figures A-21, A-22, and A-23 are radial sections of the models.

The models were mounted in a high-speed centrifuge and subjected to the centrifugal loads noted in the figure captions. They were then removed and sectioned. Figures A-24 and A-25 are photographs of the actual sectioned models. Figures A-26 and A-27 are trace drawings of the deformations.

The models are all cases in which a density inversion occurs beneath a less dense overburden (the oilwax layer). The density inversion is between a layer of painter's putty $\left(\rho=1.87 \mathrm{~g} / \mathrm{c}^{3}\right)$ and the underlying silicone putty $\left(\rho=1.14,1.25,1.35 \mathrm{~g} / \mathrm{c}^{3}\right)$. The thicknesses of the dense layer are $3,1.5$, and $1 \mathrm{~mm}$ in models S112, S114, and S116, respectively. The densities are given on Figures A-21, A-22, and A-23. The viscosities are less well determined, but are given by Ramberg (p 375) as $10^{6}-10^{7} \mathrm{P}$ for the painter's putty and $3 \times 10^{5} \mathrm{P}$ for the silicone putty.

Model scaling ratios follow from a comparison of the WIPP prototype with the models. If $1 \mathrm{~mm}$ in a model corresponds to $100 \mathrm{ft}$ in the prototype, then the subsiding layers correspond to anhydrite members 100,150 , and $300 \mathrm{ft}$ thick. For a density ratio of 0.62 , the corresponding anhydrite density is $3.02 \mathrm{~g} / \mathrm{c}^{3}$ and the corresponding "halite" layers are 1.84, 2.02, and $2.18 \mathrm{~g} / \mathrm{c}^{3}$. For a viscosity ratio of $10^{-12}$, an average model viscosity of $10^{6} \mathrm{P}$ corresponds to an evaporite viscosity of $10^{18} \mathrm{P}$. Body forces and deformation time are determined by the experiment to be about $2000 \mathrm{~g}$ and $10 \mathrm{~min}$ respectively. The duration of the prototype deformation is determined by the interdependent scaling factors to be around $700000 \mathrm{yr}$. These scaling ratios are listed on Table A-6. 


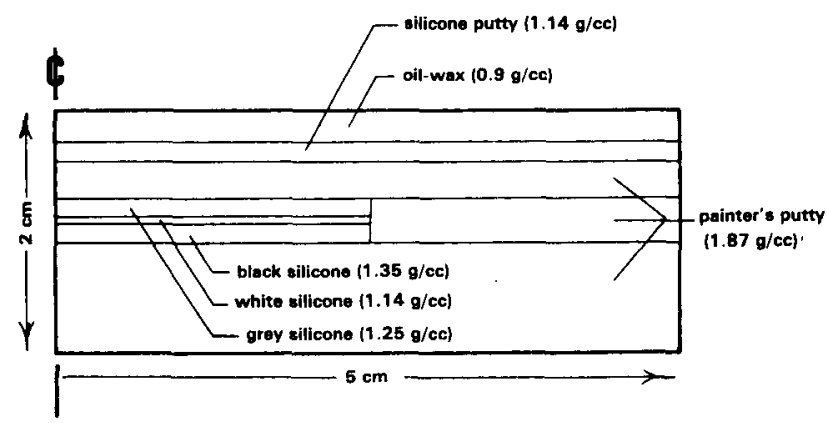

Figure A-21. Radial Section Through Centrifuge Model S112. Run at $2000 \mathrm{~g}$ for $11 \mathrm{~min}$.

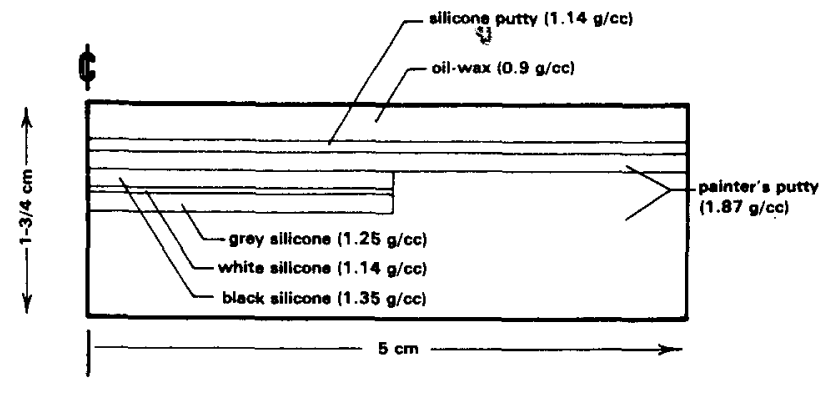

Figure A-22. Radial Section Through Centrifuge Model S114. Run at $1300-2200 \mathrm{~g}$ for $8 \mathrm{~min}$.

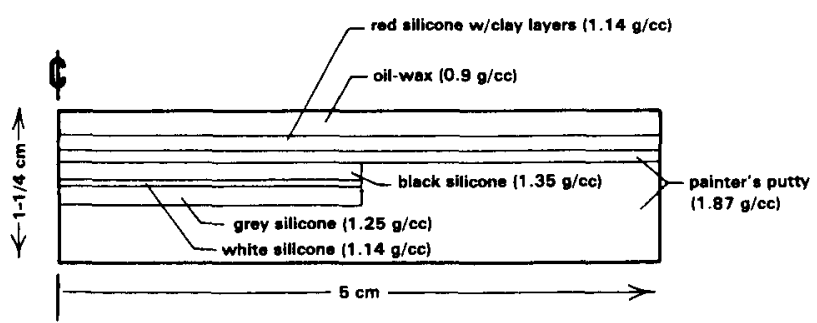

Figure A-23. Radial Section Through Centrifuge Model S116. Run at $2400 \mathrm{~g}$ for $11 \mathrm{~min}$, then $2900 \mathrm{~g}$ for $4 \mathrm{~min}$.

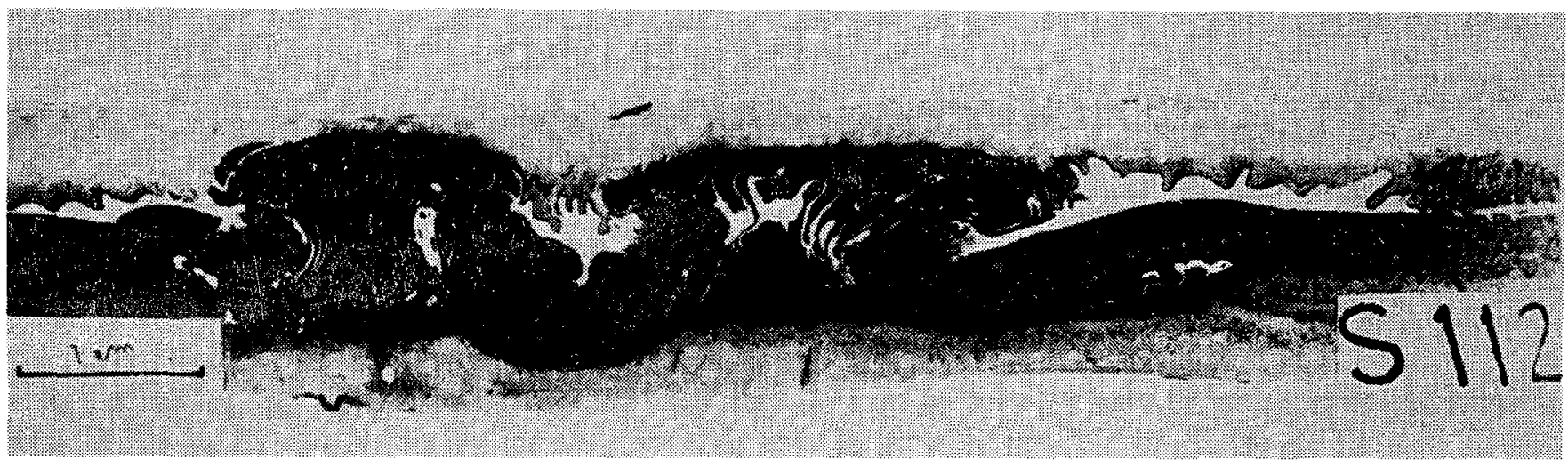

Figure A-24. (From Ramberg, p 364) 


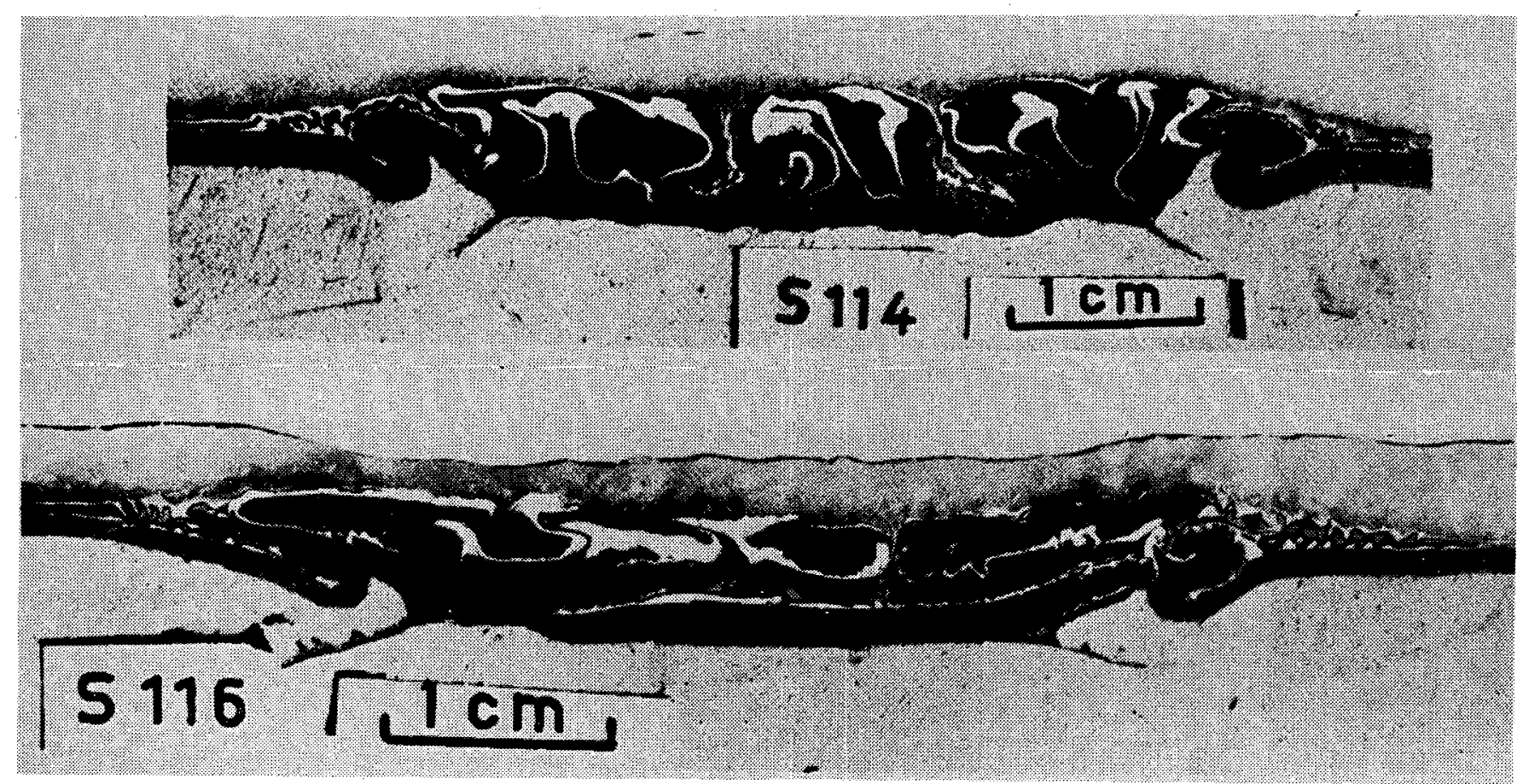

Figure A-25. (From Ramberg, p 365)

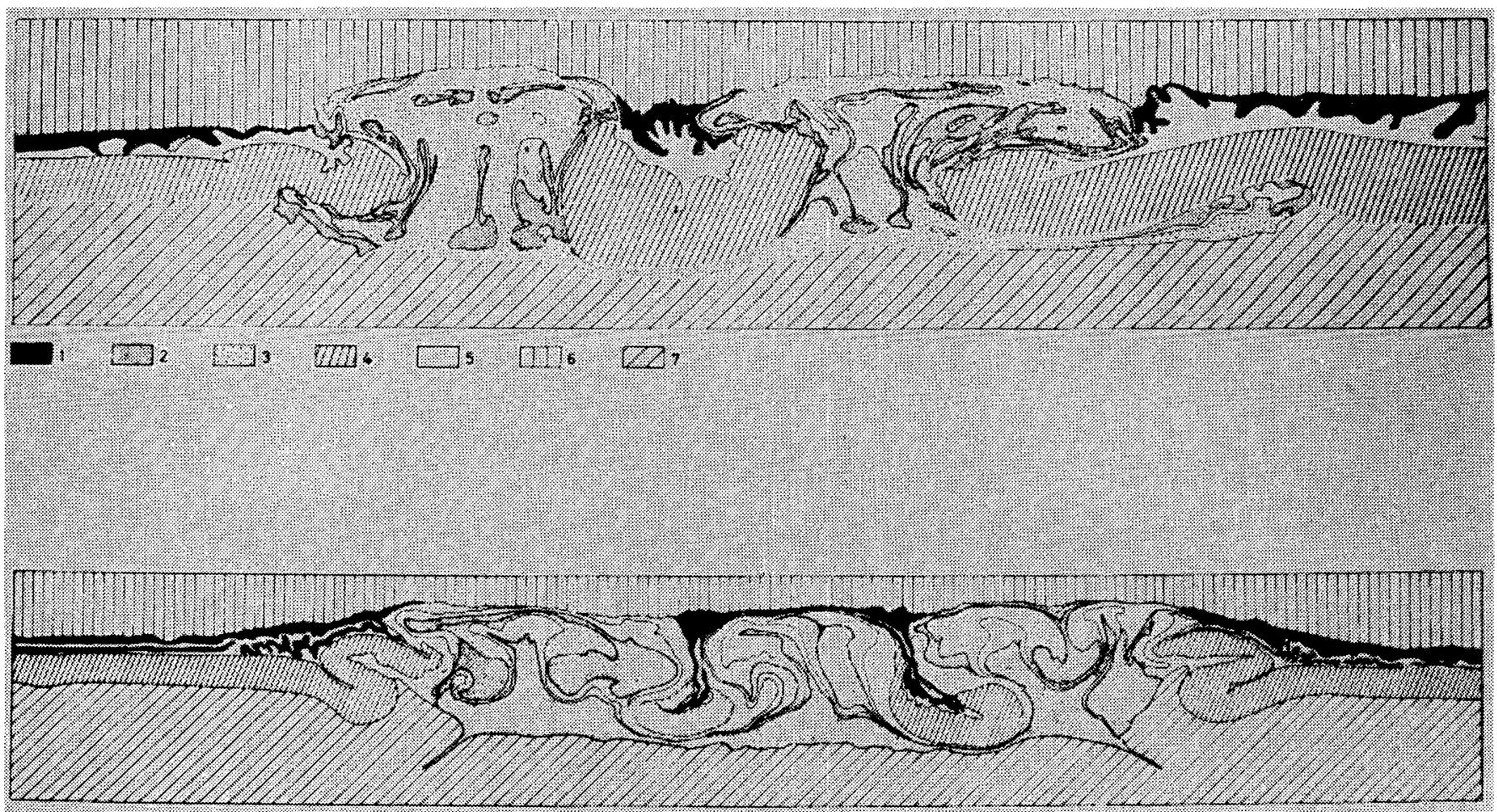

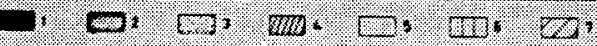

Figure A-26. (From Ramberg, p 366) 


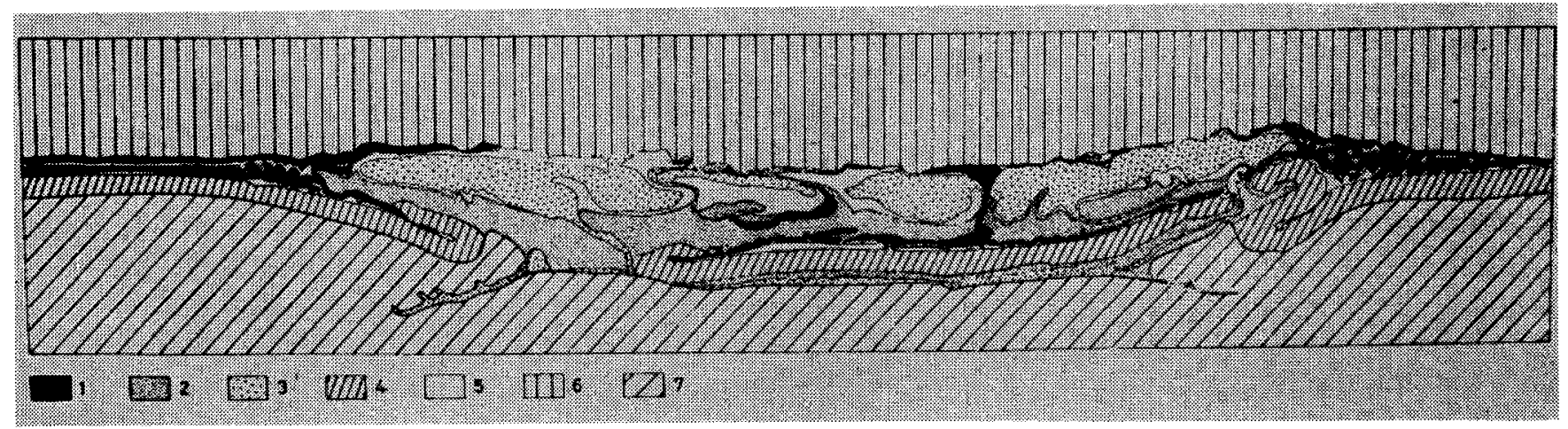

Figure A-27. (From Ramberg, p 367)

Table A-6. Ratios for Reinterpreting Models S112, S114, and S116 as Gravity Foundering of Anhydrite

\begin{tabular}{|c|c|c|c|}
\hline Quantity & Model & Prototype & Ratio \\
\hline $\begin{array}{l}\text { Thickness of the } \\
\text { subsiding layer }\end{array}$ & 1 to $3 \mathrm{~mm}$ & 100 to $300 \mathrm{ft}$ & $\ell_{\mathrm{r}}=3 \times 10^{-5}$ \\
\hline Body forces & $\begin{array}{l}\text { centrifugal } \\
\text { acceleration: } \\
2000 \mathrm{~g} \\
\text { (approximate) }\end{array}$ & gravity & $a_{r}=2000$ \\
\hline Densities: & & & \\
\hline Anhydrite & $1.87 \mathrm{~g} / \mathrm{c}^{3}$ & $3.02 \mathrm{~g} / \mathrm{c}^{3}$ & $\rho_{\mathrm{r}}=0.62$ \\
\hline $\begin{array}{l}\text { Halite } \\
\text { (3 layers) }\end{array}$ & $\begin{array}{l}1.14,1.25 \\
1.35 \mathrm{~g} / \mathrm{c}^{3}\end{array}$ & $\begin{array}{l}1.84,2.02, \\
2.18 \mathrm{~g} / \mathrm{c}^{3}\end{array}$ & \\
\hline Viscosities & $\begin{array}{l}10^{6} \mathrm{P} \\
\text { (approximate) }\end{array}$ & $10^{18} \mathrm{P}$ & $\mu_{\mathrm{r}}=10^{-12}$ \\
\hline Time & $10 \mathrm{~min}$ & $7 \times 10^{5} \mathrm{yr}$ & $\begin{array}{l}\mathrm{t}_{\mathrm{r}}=\mu_{\mathrm{r}} / \rho_{\mathrm{r}} \ell_{\mathrm{r}} \mathrm{a}_{\mathrm{r}} \\
\mathrm{t}_{\mathrm{r}}=2.7 \times 10^{-11}\end{array}$ \\
\hline
\end{tabular}


Some notes about the models:

1. The structural complexity of the models is comparable with the more deformed portions of the disturbed zone.

2. Some of the subsided units have remained intact (e.g., model S116).

3. The deformation at the free surface is much less than in the underlying materials because of the stabilizing density stratification of the air/ rock interface.

4. The less dense silicone clay layers are terminated at a vertical interface with more dense painter's putty. This boundary should influence the style of deformation.

5. Scaling factors, the resulting evolution time, and deformation wavelengths are reasonably consistent with the WIPP site analysis.

\section{Migration of Brine Pockets}

Brine pockets are irregular volumes of fluid encountered within the Castile Formation in areas of complex structures. The fluid pressures are intermediate between hydrostatic and lithostatic heads and are distinctly higher than the heads in adjacent aquifers (implying isolation from these aquifers). The origin of the brine is unknown.

Some of Ramberg's centrifuge models have a possible bearing on the migration of brine pockets. This material is included here because the process is a form of gravitational deformation, and the interpretation is similar to that in the preceding section.

The application of these models to the WIPP site is equivocal. Particularly relevant is whether the brine plays a dynamic role in creating its reservoirs. If the reservoirs result from extension fractures in folded anhydrite and the brine passively fills these fractures, then the following material should not apply. However, the brine pockets may form by concentrating previously disseminated fluids in low stress regions within the developing structures. Then the reservoir volume would be created or held open by the fluid pressure within the brine. In this case, the density difference between the brine and its host rock creates a tendency for the brine to rise through the section. Whether it does rise (and how fast) depends upon effective viscosities, yield strengths, and physical dimensions.

The model considered here is described in detail in Chap 13 of Ramberg's text (model M). It was originally constructed to represent the rise of less dense fluid magma through a heavier overburden but, by redefining the prototype dimensions, it applies equally well to the ascent of brine through evaporites.
The model consisted of a small volume of $\mathrm{KMnO}_{4}$ aqueous solution beneath interlayered modeling clay and painter's putty. The $\mathrm{KMnO}_{4}$ stained the modeling clay and putty as the fluid migrated, providing a record of the fluid path. Figure A-28 is a radial section through the model.

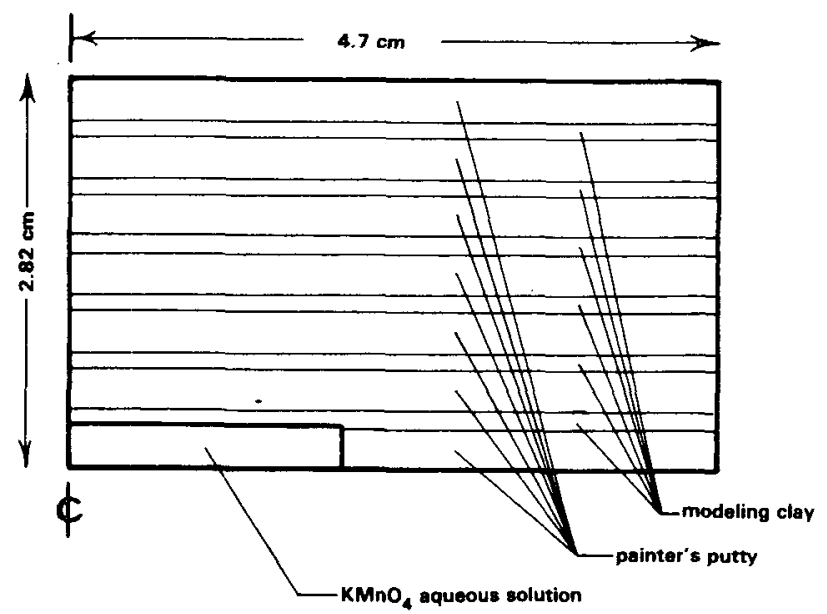

Figure A-28. Radial Section Through Centrifuge Model M. Run at $210 \mathrm{~g}$ for $4.5 \mathrm{~min}$.

The model was subjected to centrifugal forces of $210 \mathrm{~g}$ for $4.5 \mathrm{~min}$. The fluid penetrated the surface in $3.75 \pm 0.75 \mathrm{~min}$. Figure A-29 shows a series of slices through the model. The fluid appears to have followed a complex system of anastomosing channels.

Extrapolating this model to the migration of brine through the evaporites requires establishing model ratios for length, viscosity, density, and acceleration. The model ratio for time follows from these other ratios.

The length ratio is established by comparing the volume of fluid in the model with the volume of a brine pocket. The brine pocket is here assumed to contain a quarter of a million barrels. The model fluid volume is

$V_{m}=h \times \pi r^{2}=4021 \mathrm{~mm}^{3}$

A quarter-of-a-million-barrel brine pocket is

$V_{p}=0.25 \times 10^{6} \mathrm{bbl}=4 \times 10^{13} \mathrm{~mm}^{3}$ 


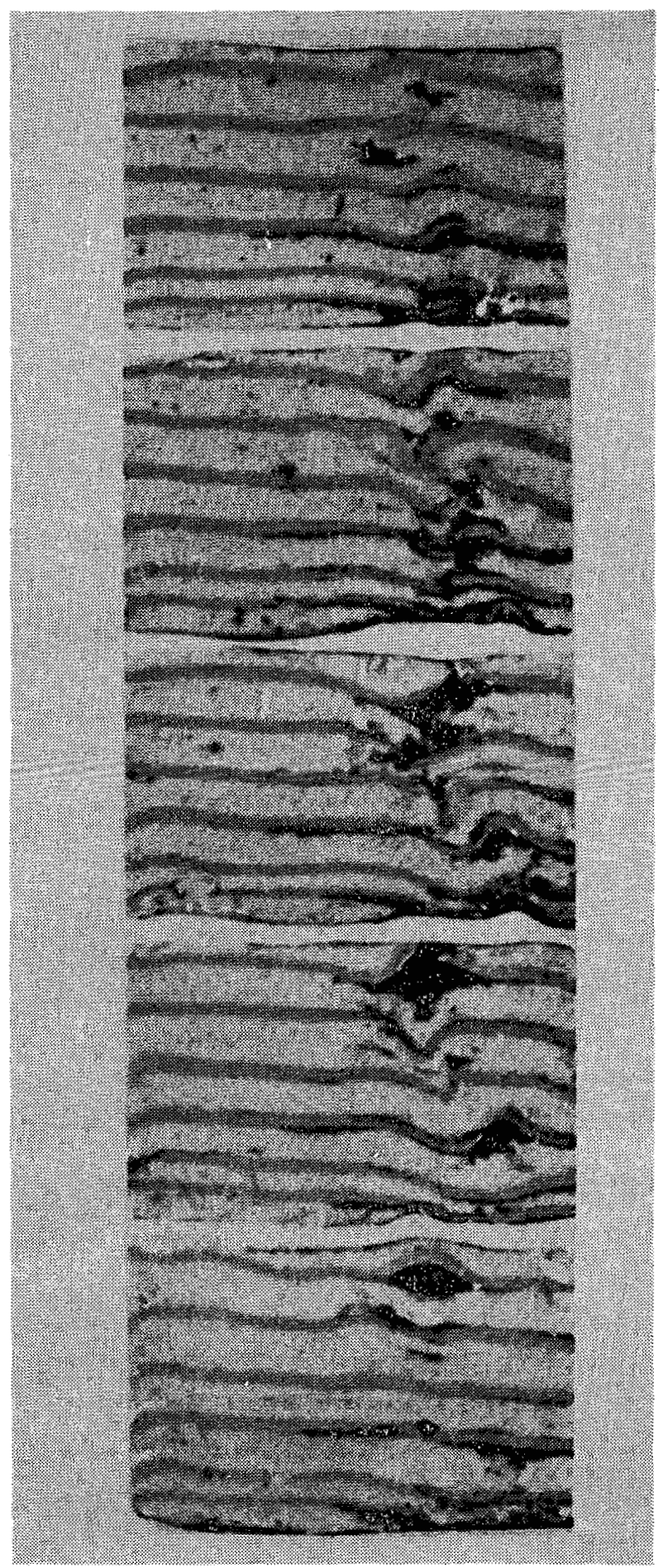

Figure A-29. (Ramberg, p 334)
The volume ratio is

$V_{r}=V_{p} \div V_{p}=10^{-10}$

and the length ratio is

$\ell_{\mathrm{r}}=\sqrt[3]{\mathrm{V}_{\mathrm{r}}}=5 \times 10^{-4}$

The viscosity ratio is uncertain by several orders of magnitude but can be estimated. The viscosity of the modeling clay is between $0.5 \times 10^{8}$ and $7.4 \times 10^{8} \mathrm{P}$. The painter's putty varies between $10^{5}$ and $10^{8} \mathrm{P}$ with values up to $10^{8} \mathrm{P}$ when the strain is large and the stress is of the order of $10^{6} \mathrm{dyne} / \mathrm{cm}^{2}$. For these calculations a uniform model viscosity of $10^{8} \mathrm{P}$ is assumed. Salt viscosity has been experimentally determined to be around $10^{17} \mathrm{P}$, and $10^{18} \mathrm{P}$ was found to give geologically reasonable rates of salt dome evolution in models $(0.2 \mathrm{~cm} / \mathrm{yr}$, Ramberg, Chap 12). Wet salt may be much less viscous (Wenkert, 1979). For these calculations a uniform evaporite viscosity of $10^{18} \mathrm{P}$ is assumed. The viscosity ratio is then

$\mu_{\mathrm{r}}=\mu_{\text {model }} / \mu_{\text {prototype }}=10^{-10}$

The fluid viscosity of the model $\left(10^{-2} \mathrm{P}\right)$ then corresponds to a prototype brine viscosity of $10^{8} \mathrm{P}$. While this viscosity is much larger than the actual brine, the contrast between it and the evaporites should be sufficient to believe that the model fluid corresponds to a mechanically inviscid fluid in the prototype.

The density of the model fluid should be near $1 \mathrm{~g} / \mathrm{c}^{3}$ (it is not specified in the text). Brine density is near $1.2 \mathrm{~g} / \mathrm{c}^{3}$; the density ratio is thus

$\rho_{\mathrm{r}}=\rho_{\text {model }} / \rho_{\text {prototype }}=0.83$

The density of the modeling clay (1.67 to $1.71 \mathrm{~g} / \mathrm{c}^{3}$ ) then corresponds to prototype densities of 1.93 to $2.05 \mathrm{~g} / \mathrm{c}^{3}$ and the painter's putty $\left(1.8\right.$ to $\left.1.9 \mathrm{~g} / \mathrm{c}^{3}\right)$ to 2.16 to $2.28 \mathrm{~g} / \mathrm{c}^{3}$. This is reasonably close to the density of rock salt.

The ratio of the body forces is just the centripetal acceleration expressed in "g," or (for this model)

$a_{\mathbf{r}}=210$ 
The time ratio follows directly from the ratios of length, viscosity, density, and body force as

$\mathrm{t}_{\mathrm{r}}=\frac{\mu_{\mathrm{r}}}{\rho_{\mathrm{r}} \ell_{\mathrm{r}} \mathrm{a}_{\mathrm{r}}}$

Substituting

$\mu_{\mathrm{r}}=10^{-10}$

$\rho_{\mathrm{r}}=0.83$

$\ell_{\mathrm{r}}=5 \times 10^{-4}$

$a_{r}=210$

then

$t_{r}=1.1 \times 10^{-9}$

The model time necessary for the solution to penetrate the overburden $(3.75 \mathrm{~min})$ corresponds to $6500 \mathrm{yr}$. The $28 \mathrm{~mm}$ of model overburden corresponds to $56 \mathrm{~m}$ in the prototype; thus the prototype brine velocity is around $1 \mathrm{~cm} / \mathrm{yr}$. The time required to penetrate $3000 \mathrm{ft}$ is then $10^{5} \mathrm{yr}$.

\section{Discussion}

The analysis and centrifuge models demonstrate how DZ deformations can result from gravity foundering. These results follow directly from known thicknesses and densities of the stratigraphic section and from reasonable estimates of the effective viscosity. DZ deformations are the expected result of the existing physical situation.

The question is not why the DZ developed, but why the entire Delaware Basin has not similarly deformed. A possible explanation lies in the dependency of gravitational tectonic stress on the amplitude of the density structure. In the preceding theoretical analysis of gravitational instabilities in a layered system, it was noted that the velocity or deformation rate is proportional to the amplitude of the existing deformation. Because the gravitational stress is linearly dependent on both the amplitude and deformation rate, small deformations imply small gravitational tectonic stresses. No deformation would occur if the evaporites possess a finite yield strength that exceeds the small gravitational tectonic stress associated with natural low-amplitude sedimentary structures. Secondary processes, such as external tectonic faulting, could produce an initial structure whose inherent gravitational tectonic stress exceeds the yield strength. The deformation would then grow outward from this area. An indication of such initiating structures is the structural high at the top of Anhydrite I at borehole WIPP 11.

An alternate interpretation for the localization of complex structures within undeformed areas is suggested by the role of water on evaporite rheology. Wenkert (1979) noted that strain rate in Iranian salt glaciers was very much larger than predicted by previously investigated halite flow mechanisms. He attributed this to interstitial saltwater solution. D. Borns (pers. comm.) has identified low-temperature pressure solution facilitated by water as the primary deformation mechanism in the DZ. Anomalous water conditions are supported by the occurrence of brine pockets in disturbed structures in the northern Delaware Basin. In this interpretation, the complex structures form in areas where anomalous intergranular water facilitates grain boundary pressure solution.

If the $\mathrm{DZ}$ resulted from gravitational foundering, then the driving force will remain in effect until all the anhydrite has settled beneath the less dense halite. In this sense, the deformation should be regarded as active. However, the deformation has minimal effect at the level of the proposed waste repository, and the rates of deformation are slow. 


\section{References}

C. A. Anderson, "Simplicity in Structural Geology," in C. C. Albritton, Fabric of Geology (Geological Society of America, Reprinted 1963, pp 175-183).

R. Y. Anderson, "Correlation and Structural Relationships of the Castile-Salado Evaporite Sequence in ERDA \#6, AEC \#7, and AEC \#8 Boreholes, Eddy and Lea Counties, New Mexico," report to Sandia Laboratories, September 1976.

R. Y. Anderson, "Deep Dissolution of Salt, Northern Delaware Basin, New Mexico," report to Sandia Laboratories, January 1978 (rev May 1978).

D. Borns, Sandia National Laboratories, personal communication, January 8, 1982.

T. C. Chamberlin, "The Method of Multiple Working Hypothesis," Science 15:92 (1890) (reprinted in 1965, 148:754).

M. T. Halbouty, Salt Domes (Houston, TX: Gulf Publishing Co., 1979).

D. W. Kirkland and R. Y. Anderson, "Microfolding in the Castile and Todilto Evaporites, Texas and New Mexico," GSA Bulletin 81:3259-3282 (1970).

H. Ramberg, Gravity, Deformation and the Earth's Crust (2nd ed; New York, NY: Academic Press, 1981).

H. I. Snider, "Stratigraphy and Associated Tectonics of the Upper Permian Castile-Salado-Rustler Evaporite Complex, Delaware Basin, West Texas and Southeast New Mexico," (PhD diss, University of New Mexico, 1966).

D. D. Wenkert, "The Flow of Salt Glaciers," Geophys Res Ltrs 6(6):523-526 (1979). 


\section{DISTRIBUTION:}

US Department of Energy, Headquarters (3)

Office of Nuclear Waste Management

Washington, DC 20545

Attn: Larry Harmon, Program Manager (WIPP)

Wade Ballard, Director,

Division of Waste Isolation (2)

US Department of Energy, Headquarters

Office of Defense Waste \& By-Products

Washington, DC 20545

Attn: Dr. Goetz Oertel, Director (NE-320)

US Department of Energy (3)

Albuquerque Operations

PO Box 5400

Albuquerque, NM 87115

Attn: J. M. McGough, Mgr, WIPP Project Office (2)

D. Jackson, Director, Public Affairs Division

US Department of Energy

Carlsbad WIPP Project Office

Room 113, Federal Building

Carlsbad, NM 88220

US Department of Energy

c/o Battelle Office of Nuclear Waste Isolation

505 King Ave

Columbus, OH 43201 .

Attn: Jeff O. Neff

Battelle Memorial Institute

Office of Nuclear Waste Isolation

505 King Ave

Columbus, $\mathrm{OH} 43201$

Attn: S. Goldsmith, Mgr, ONWI Library

Battelle Memorial Institute

Project Management Division

505 King Ave

Columbus, OH 43201

Attn: Neal Carter, General Manager

Bechtel National, Inc. (2)

Fifty Beale St

PO Box 3965

San Francisco, CA 94119

Attn: D. L. Ledbetter

Dale Roberts
D’Appolonia Consulting Engineers (10)

2340 Alamo, SE

Albuquerque, NM 87106

Attn: Dev Shukla

Westinghouse Electric Corporation (3)

PO Box 40039

Albuquerque, NM 87196

Attn: R. K. Brown

R. Jones (TSC)

C\&C File, c/o Ginger Wilkenson

Frank L. Parker, Chairman

Department of Environmental and

Water Resources Engineering

Vanderbilt University

Nashville, TN 37235

Konrad B. Krauskopf, Vice Chairman

Department of Geology

Stanford University

Stanford, CA 94305.

Karl P. Cohen, Consultant

928 N California Ave

Palo Alto, CA 94303

Neville G. W. Cook

Dept of Material Sciences and Engineering

University of California at Berkeley

Hearst Mining Building, \#320

Berkeley, CA 94720

Fred M. Ernsberger

250 Old Mill Road

Pittsburgh, PA 15238

Richard R. Parizek

Department of Hydrogeology

Pennsylvania State University

University Park, PA 16802

D'Arcy A. Shock

233 Virginia

Ponca City, OK 74601 
John W. Winchester

Department of Oceanography

Florida State University

Tallahassee, FL 32306

John T. Holloway

Senior Staff Officer

2101 Constitution Ave, NW

Washington, DC 20418

University of California at Los Angeles

Department of Earth and Space Sciences

Los Angeles, CA 90024

Attn: J. Rosenfeld

The University of Texas

Department of Geological Sciences

PO Box 7909

Austin, TX 78712

Attn: J. K. Warren

California State University Long Beach

Department of Geological Sciences

1250 Bellflower Boulevard

Long Beach, CA 90840

Attn: J. G. Dennis

Dr. U. A. Pfirter

Universität Basel

Geologisch-paläontologiches Institut

Bernoullistrasse 32

CH-4056 Basel

Switzerland

WIPP Public Reading Room

Atomic Museum, KAFB East

Albuquerque, NM 87185

Attn: Ms. Gwynn Schreiner

WIPP Public Reading Room

Carlsbad Municipal Library

$101 \mathrm{~S}$. Hallagueno St

Carlsbad, NM 88220

Attn: Lee Hubbard, Head Librarian

Thomas Brannigan Library

$106 \mathrm{~W}$ Hadley St

Las Cruces, NM 88001

Attn: Don Dresp, Head Librarian
Roswell Public Library

301 N Pennsylvania Ave

Roswell, NM 88201

Attn: Ms. Nancy Langston

Hobbs Public Library

509 N Ship St

Hobbs, NM 88248

Attn: Ms. Marcia Lewis, Librarian

State of New Mexico (2)

Environmental Evaluation Group

320 Marcy St

PO Box 968

Santa Fe, NM 87503

Attn: Robert H. Neill, Director

NM Department of Energy \& Minerals (2)

PO Box 2770

Santa Fe, NM 87501

Attn: Larry Kehoe, Secretary Kasey LaPlante, Librarian

New Mexico State Geologist

PO Box 2860

Santa Fe, NM 87501

Attn: Emery C. Arnold

New Mexico State Library

PO Box 1629

Santa Fe, NM 87503

Attn: Ms. Ingrid Vollenhofer

New Mexico Tech

Martin Speer Memorial Library

Campus St

Socorro, NM 87801

Zimmerman Library

University of New Mexico

Albuquerque, NM 87131

Attn: Ms. Zanier Vivian

USGS, Water Resources Division (2)

505 Marquette, NW

Western Bank Bldg, \#720

Albuquerque, NM 87102

Attn: J. W. Mercer 
DISTRIBUTION (cont):

USGS, Conservation Division

PO Box 1857

Roswell, NM 88201

Attn: W. Melton

USGS, Special Projects Branch (2)

Federal Center, Bldg 25

Denver, CO 80225

Attn: R. P. Snyder

NM Bureau of Mines and Mineral Resources (2)

Socorro, NM 87801

Attn: F. E. Kottlowski, Director

Klaus Kuhn

Gesellschaft fuer Strahlen-und

Umweltforschung MBH Muenchen

Institut fuer Tieflagerung

Berliner Strasse 2

3392 Clausthal-Zellerfeld

Federal Republic of Germany

Klaus Eckart Maass

Hahn-Meitner-Institut fuer Kernforschung

Glienicker Strasse 100

1000 Berlin 39

Federal Republic of Germany

Michael Langer

Bundesanstalt fuer Geowissenschaften und Rohstoffe

Postfach 510153

3000 Hannover 51

Federal Republic of Germany

Helmut Rothemeyer

Physikalisch-Technische

Bundesanstalt

Bundesalle 100

3300 Braunschweig

Federal Republic of Germany

Rolf-Peter Randl

Bundesmisterium fuer Forschung und Technologie

Postfach 200706

5300 Bonn 2

Federal Republic of Germany
Fenix \& Scisson, Inc.

$3170 \mathrm{~W}$ Sahara Avenue

Spanish Oaks D-12

Las Vegas, NV 89102

Attn: J. A. Cross

Gayle Pawloski, L-222

Geologist CSDP

Lawrence Livermore Laboratory

Livermore, CA 94550

US Nuclear Regulatory Commission (3)

Division of Waste Management

Mail Stop 69755

Washington, DC 20555

Attn: J. Martin

M. Bell

H. Miller

Dr. Gary :. Downey

Center of Waste Management Programs

Department of Social Sciences

Michigan Technological University

Houghton, MI 49931

Dennis W. Powers

Department of Geological Sciences

University of Texas at El Paso

El Paso, TX 79968

$\begin{array}{ll}7111 & \text { L. J. Barrows (6) } \\ 7133 & \text { R. D. Statler } \\ 7135 & \text { P. D. Seward } \\ 9700 & \text { E. H. Beckner } \\ 9730 & \text { W. D. Weart } \\ 9731 & \text { A. R. Lappin (5) } \\ 9731 & \text { D. J. Borns (15) } \\ 9731 & \text { D. D. Gonzalez } \\ 9731 & \text { S. J. Lambert } \\ 9731 & \text { K. L. Robinson } \\ 9731 & \text { S. E. Shaffer } \\ 9731 & \text { C. L. Stein } \\ 9732 & \text { Sandia WIPP Central Files (12) } \\ 9753 & \text { J. C. Lorenz } \\ 8214 & \text { M. A. Pound } \\ 3141 & \text { L. J. Erickson (5) } \\ 3151 & \text { W. L. Garner (3) } \\ 3154-3 & \text { C. H. Dalin (25) } \\ & \text { For DOE/TIC (Unlimited Release) }\end{array}$

